\title{
Sedimentology of historic and prehistoric deposits in the drainage basin of Deep River and Muddy Creek on the Piedmont of North Carolina
}

Victoria Leanne Spurgeon

West Virginia University

Follow this and additional works at: https://researchrepository.wvu.edu/etd

\section{Recommended Citation}

Spurgeon, Victoria Leanne, "Sedimentology of historic and prehistoric deposits in the drainage basin of Deep River and Muddy Creek on the Piedmont of North Carolina" (2000). Graduate Theses, Dissertations, and Problem Reports. 1116.

https://researchrepository.wvu.edu/etd/1116

This Thesis is protected by copyright and/or related rights. It has been brought to you by the The Research Repository @ WVU with permission from the rights-holder(s). You are free to use this Thesis in any way that is permitted by the copyright and related rights legislation that applies to your use. For other uses you must obtain permission from the rights-holder(s) directly, unless additional rights are indicated by a Creative Commons license in the record and/ or on the work itself. This Thesis has been accepted for inclusion in WVU Graduate Theses, Dissertations, and Problem Reports collection by an authorized administrator of The Research Repository @ WVU. For more information, please contact researchrepository@mail.wvu.edu. 


\title{
Sedimentology of Historic and Prehistoric Deposits in the Drainage Basin of Deep River and Muddy Creek on the Piedmont of North Carolina
}

\author{
V. Leanne Spurgeon \\ Thesis submitted to the \\ College of Arts and Sciences \\ at West Virginia University \\ in partial fulfillment of the requirements \\ for the degree of \\ Master of Science \\ in \\ Geology \\ Dr. J. Steven Kite (Chair) \\ Dr. John J. Renton \\ Dr. Robert E. Behling \\ Keith Seramur \\ Department of Geology and Geography \\ Morgantown, West Virginia \\ 2000
}

Key Words: Floodplain Sedimentology, Magnetic Susceptibility, Floodplain Geomorphology, North Carolina Copyright 2000 V. Leanne Spurgeon 


\section{ABSTRACT \\ Sedimentology of Historic and Prehistoric Deposits in the Drainage Basin of Deep River and Muddy Creek on the Piedmont of North Carolina}

\section{Leanne Spurgeon}

Deep River and Muddy Creek flow across a granitic and volcanic terrain intruded by diabase dikes in the Piedmont physiographic province of central North Carolina. Geoarchaeological and sedimentological investigation of these Piedmont streams included fourteen trenches dug at four floodplain localities. Soils in these trenches were described using standard soil taxonomy and sampled for particle-size, magnetic susceptibility, and mineralogical analyses.

Increased upland erosion rates, after European settlement, left more than a meter of historic sediments in some areas of the floodplains. A paleosol, indicated by an Ab horizon, records the floodplain surface at the time of European contact. This paleosol, dated by Coastal Carolina Research of Tarboro, North Carolina, was used to differentiate historic and prehistoric deposits.

Although historic and prehistoric sediments have similar sedimentological characteristics, there are trends that differentiate the two populations. Historic sediments have a coarser mean particle size than prehistoric sediments. Historic deposits show a general increase in magnetic susceptibility as particle size decreases from sand to silt; a trend not apparent in prehistoric deposits. Analyses indicate mineralogy varies with particle-size and that the trends in mineralogy are different for historic and prehistoric sediments. The combined chemical and mineralogical analyses show $\mathrm{Fe}_{2} \mathrm{O}_{3}, \mathrm{MnO}, \mathrm{TiO}_{2}$, $\mathrm{Al}_{2} \mathrm{O}_{3}, \mathrm{MgO}$, epidote, hornblende, and $14 \AA$ clays are associated with high magnetic susceptibility in fine-grained historic sediments. Magnetic susceptibility is higher in the interval from fine sand to fine silt in the prehistoric sediments. The magnetic susceptibility in prehistoric sediments is associated with $\mathrm{MgO}, \mathrm{TiO}_{2}, \mathrm{MnO}, \mathrm{CaO}, \mathrm{Na}_{2} \mathrm{O}$, and hornblende. Epidote, $14 \AA$ clays, $\mathrm{Fe}_{2} \mathrm{O}_{3}$, and $\mathrm{Al}_{2} \mathrm{O}_{3}$ are associated with high magnetic susceptibility in the clay fraction. 


\section{TABLE OF CONTENTS}

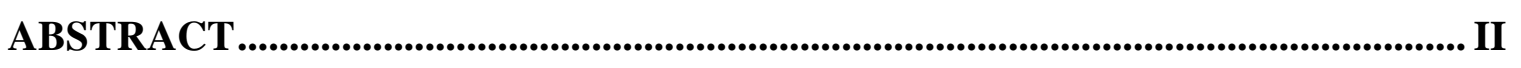

TABLE OF CONTENTS ...........................................................................................................II

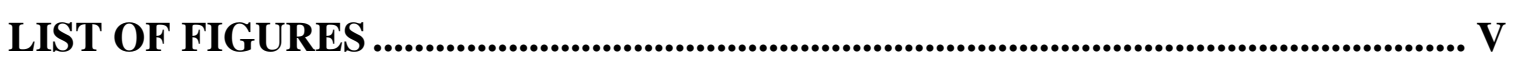

ACKNOWLEDGEMENTS .............................................................................VIII

INTRODUCTION.......................................................................................... 1

PURPOSE ............................................................................................................................. 2

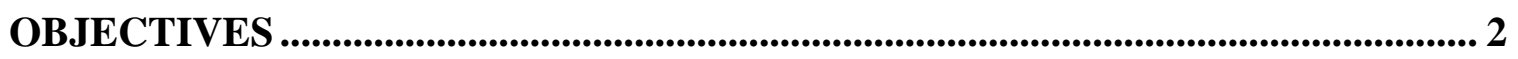

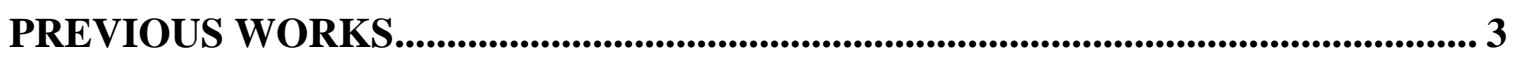

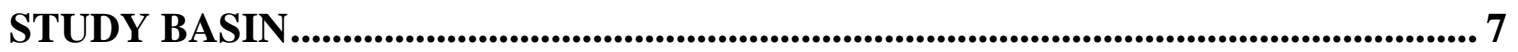

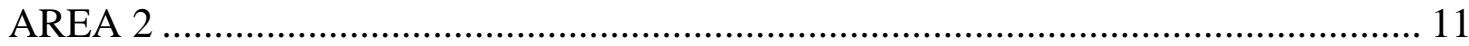

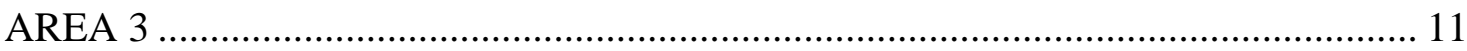

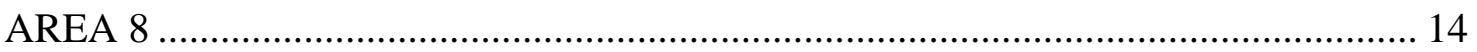

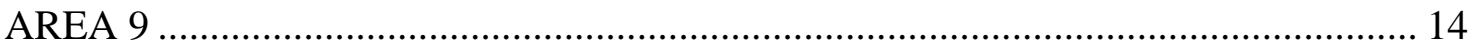

RESEARCH METHODOLOGY .................................................................... 17

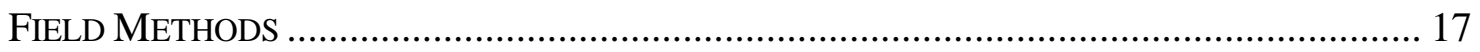

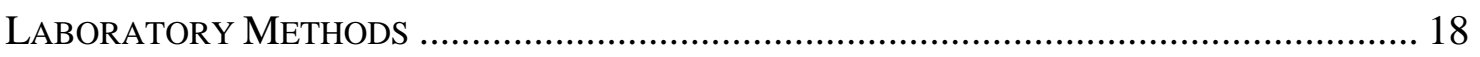

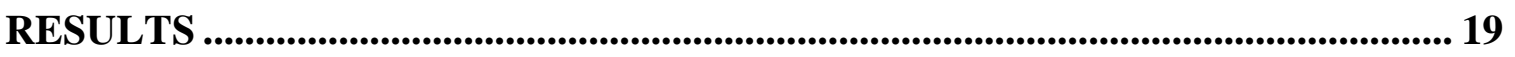

PARTICLE-SIZE AND MAGNETIC SUSCEPTIBILITY …………....................................... 20

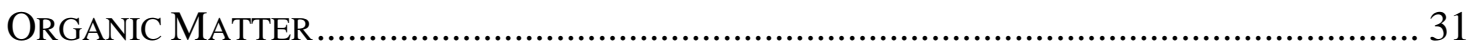

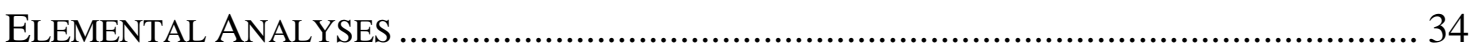

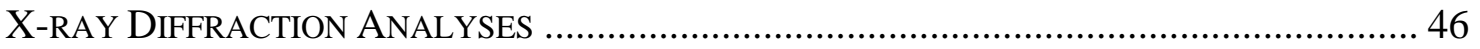

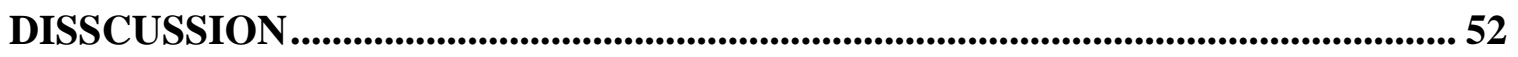

CONCLUSIONS .................................................................................................................... 57

REFERENCES CITED ..................................................................................62

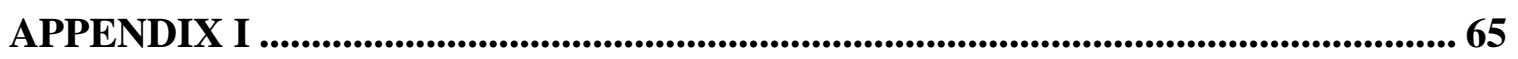

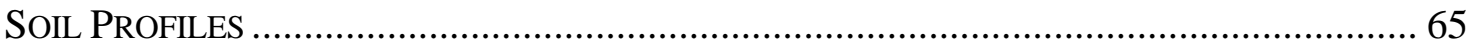

APPENDIX II......................................................................................................................... 74

Procedure For MEASURING Magnetic SusCePTIBILITY

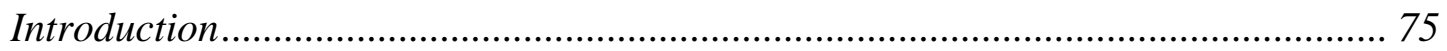

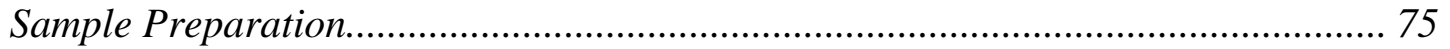




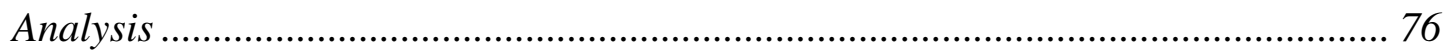

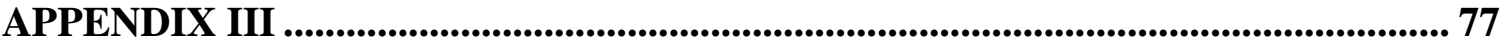

PARTICLE-SIZE ANALYSIS

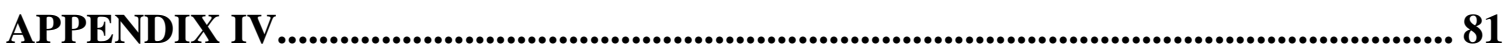

SEDIMENTOLOGICAL DATA

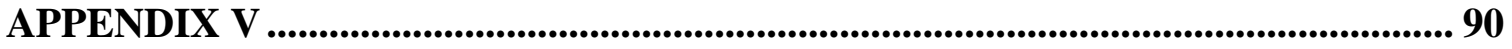

MAGNETIC SuscePtibILITy AND ORGANIC MATTER DATA

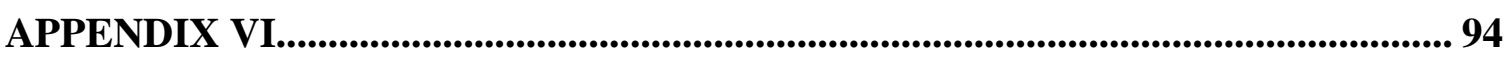

ELEMENTAL AND X-RAY DIFFRACTION DATA

APPENDIX VII ................................................................................................................. 96

BIVARIATE Plots \& R VALUES 


\section{LIST OF FIGURES}

1. Figure 1. Map showing area locations used for Phase I and II archaeology surveys

2. Figure 2. Detailed map of Area 2.

3. Figure 3. Map of Area 3 with trench locations .13

4. Figure 4. Field location of Area 8

5. Figure 5. There are four known archaeology sites and three trenches, from Area 9, used in this study.....

6. Figure 6. Particle size frequency chart showing a bimodal distribution

7. Figure 7. The relationship between mean and standard deviation for the historic and prehistoric sediments

8. Figure 8 . Tertiary diagram showing historic sediments to be more sandy while prehistoric sediments tend to be slightly more clayey

9. Figure 9. Phi interval v. Magnetic Susceptibility

10. Figure 10. Plot of $r$-values for relationship between particle size and magnetic susceptibility

11. Figure 11. Organic matter increases as particle-size decreases in both historic and prehistoric sediments

12. Figure 12. $r$ values calculated for each particle size interval and plotted in descending particle size for $\mathrm{Al}_{2} \mathrm{O}_{3}$ and $\mathrm{Fe}_{2} \mathrm{O}_{3}$

13. Figure 13. Particle size correlates to percent oxide similarly in the historic sediments for $\mathrm{MnO}, \mathrm{TiO}_{2}$ and $\mathrm{MgO}$

14. Figure 14. Properties of $\mathrm{Na}_{2} \mathrm{O}$ and $\mathrm{SiO}_{2}$ are similar in the historic sediments

15. Figure 15. Relationships between between particle size and $\mathrm{CaO}$ and $\mathrm{P}_{2} \mathrm{O}_{5}$

16. Figure. 16. The transition elements 21 through 30, their common ions, number of $3 \mathrm{~d}$ electrons, and their magnetic moment (expressed in terms of Bohr magnetons, $\mathrm{mb})$ 
17. Figure 17. $\mathrm{Fe}_{2} \mathrm{O}_{3}, \mathrm{TiO}_{2}$, and $\mathrm{MnO}$ trends in historic sediment are similar to their trends in the prehistoric sediment

18. Figure 18. Trends in $\mathrm{Al}_{2} \mathrm{O}_{3}$ and magnetic susceptibility are similar to those in $\mathrm{Fe}_{2} \mathrm{O}_{3}$, $\mathrm{TiO}_{2}$ and $\mathrm{MnO}$.

19. Figure 19. Plots for percent $\mathrm{MgO}, \mathrm{CaO}$, and $\mathrm{P}_{2} \mathrm{O}_{5}$ show different trends

20. Figure 20. The $r$ values plotted in order of decreasing particle size show mineralogical differences in historic and prehistoric sediments

21. Figure 21. Plots of $r$ values showing trends in albite and quartz

22. Figure 22. Trends in epidote and hornblende versus magnetic susceptibility are significant in historic sediments

23. Figure 23. Plots show relationships between magnetic susceptibility and albite and quartz

24. Figure 24. Plot showing oxides and minerals when compared to particle size for historic sediments

25. Figure 25. Plot showing all oxides and minerals when compared to particle size for prehistoric sediments 


\section{LIST OF TABLES}

1. Table 1. Approximate ages for periods and sub-periods of Indian occupations....... 10

2. Table 2. Summary of $r$-values generated from plots in Figure 9 .........................28 


\section{ACKNOWLEDGEMENTS}

This project was accomplished with the help of several organizations and facilities. The first of them is the West Virginia University Mineralogy Lab. Without their help the x-ray diffraction and x-ray florescence analysis would not have been possible. Thanks Duke and Dr. Renton. Also at West Virginia University I received a monetary amount for the research from the Schumaker Fund. For this, I would particularly like to thank Dr. Robert Schumaker and his wife Beverly for their contribution to this study, as well as, their support of the WVU geology department. I would also like to thank the Appalachian State Sedimentology Lab. Their help allowed me to greatly increase my database and decrease the time I had to spend collecting the data. I am, of course, forever indebted to Dr. Ellen Cowan for this opportunity. I would also like to acknowledge Geonetics Corporation of Boone, North Carolina and Coastal Carolina Research of Tarboro, North Carolina. Without their financial and technical support this research project would not have been accomplished. And finally, I received a grant from the southeastern section of the Geological Society of America. Their support for this project, as well as, their seemingly never-ending support for graduate research should be recognized.

I would like to thank those people who have been supportive of me both technically and personally. My committee members Dr. Jack Renton and Dr. Bob Behling were especially helpful in giving me ideas and in reviewing the text. Also, my parents and my grandparents, of whom without I could never completed my education. Their continual support and encouragement is greatly appreciated. I would also like to thank Rob Woodson for just listening to me complain. Lastly, but certainly not least, I would like to thank Keith Seramur and Dr. Steven Kite. Keith was the driving force behind this project. He gave me the opportunity to come work with him in North Carolina and helped me to shape the project. Of course without Dr. Kite this text might not be legible. Thanks for all the discussions, revisions, and the comical doodles.

Thanks to all! 


\section{INTRODUCTION}

Historic agricultural development and urban land use have caused increases in flooding, erosion, and sedimentation (Costa, 1975; Happ, 1940; Knox, 1977; Knox, 1987; Magilligan, 1985; Trimble, 1975). The increase in erosion from agricultural and urban development has subsequently lead to an increase in sedimentation on floodplains. Historical alluvial sequences are stored for relatively long periods of time as thick sequences (Costa, 1977; Jacobsen and Coleman, 1986; Knox, 1987; Trimble, 1983). Deposition and storage of sediments play a key role in shaping the context of archaeology sites located in floodplains. Because archaeology sites commonly show little or no evidence of their presence prior to being unearthed, understanding the relationships between archaeology, soil properties, and geomorphic processes becomes extremely important for site identification (Hall, 1983). Identification of sites can be made more precise through Quaternary studies, which help to produce specific keys for site prediction and characterization (Stafford, 1981). Geological studies of floodplains are a major concern in archaeological research (Larsen and Schuldenrein, 1990). In a floodplain setting, sediments are the physical context for artifacts, geological information, and biological information (Gladfelter, 1985; Bettis and Benn, 1984). Conclusions are drawn about archaeology sites from information obtained from the associated sediments (Bettis and Benn, 1984). Therefore, archaeology sites cannot be studied independent of their sedimentary context (Bettis and Benn, 1984).

The relationship between artifacts and stratigraphy or soil development can be used to predict site locations within a drainage basin. Soil formation is very much related 
to alluvial depositional histories as it is interrupted when alluvial deposition occurs, forming buried paleosols (Ferring, 1992). Intervals of geomorphic stability (nondeposition) promote soil-profile development while intervals of overbank accretion interrupt soil development (Ferring, 1992). Differentiation of distinct stratigraphic units, such as paleosols, may allow separation of historic and prehistoric sediments. However, if a paleosol is not apparent then another means is needed to identify the historicprehistoric boundary.

This thesis project focused on floodplain sedimentation and its relationship to archaeology; it will allow archaeologists to better target their testing and excavation efforts and have more informative data recovery. The Deep River and Muddy Creek in central North Carolina represent a case study to show how to characterize and identify historic and prehistoric floodplain sediments based on sedimentological and mineralogical characteristics.

\section{PURPOSE}

Buried paleosols are archaeologically important because they are former stable surfaces that have the potential to contain relatively undisturbed artifacts. Unfortunately, paleosols may be difficult to visually identify within floodplain soil profiles in geomorphically active areas. The main purpose of this study was to compare and contrast the sedimentology and mineralogy of floodplain deposits in order to identify differences in prehistoric sediments and historic sediments.

\section{OBJECTIVES}

This study attempts to differentiate historic fluvial sediment from prehistoric 
sediment in the North Carolina Piedmont by addressing the following:

1. Soil morphology, which can be used to differentiate time-boundary surfaces by identifying historic alluvium and paleosols in the floodplain stratigraphy,

2. Bulk magnetic susceptibility of historic and prehistoric sediments, and

3. Sedimentology and mineralogy of historic and prehistoric sediments.

\section{PREVIOUS WORKS}

Agricultural development and urban land use have caused increases in flooding and erosion (Costa, 1975; Happ, 1940; Knox, 1977; Knox, 1987; Magilligan, 1985;

Trimble, 1975). The increase in erosion because of development has subsequently led to an increase in floodplain sedimentation. Generally, material eroded in a watershed is not moved through the fluvial system quickly, but is stored on colluvial slopes or on floodplains (Gottschalk and Jones, 1955). An increase in floodplain sedimentation allows alluvium to be deposited and stored for relatively long periods of time as thick sequences (Costa, 1977; Jacobsen and Coleman, 1986; Knox, 1987; Trimble, 1983). Historical alluvial sequences, up to 4 meters thick, have been documented in the upper Mississippi River valley, with historic sedimentation rates as high as $5.0 \mathrm{~cm} / \mathrm{y}$, compared to prehistoric rates of $0.02 \mathrm{~cm} / \mathrm{y}$ (Knox, 1977 and 1987). In the Galena River basin of Wisconsin and Illinois, Magilligan (1985) found historic sedimentation rates of $1.9 \mathrm{~cm} / \mathrm{y}$ for the period from 1820 to 1940 , markedly less than the $0.75 \mathrm{~cm} / \mathrm{y}$ rate following the implementation of land management practices in 1940 (Magilligan, 1985). Trimble (1975) documented historic alluvium as thick as $6 \mathrm{~m}$ in the southern Piedmont of Georgia, and Costa (1975) reported $1 \mathrm{~m}$ of historic alluvium in the northern Piedmont of 
Maryland. Up to $67 \%$ of eroded material may remain within the drainage basin 150 years after agriculture began in Piedmont watersheds (Costa, 1975).

Deep and narrow channel cross sections are products of disequilibrium, specifically an over-supply of sediment (Jacobsen and Coleman, 1986; Knox, 1977; Magilligan, 1985; Trimble, 1983). Overbank accretion commonly increases bankfull depth and changes the cross-sectional area of the channel (Jacobsen and Coleman, 1986; Knox, 1977; Magilligan, 1985; Trimble, 1983). Channel geometry is not only related to the amount and type of sediment transport, but also to discharge (Magilligan, 1985). Knox (1977) was able to use the Manning equation to calculate an increase in peak discharge from $6 \mathrm{~m}^{3} / \mathrm{s}\left(65 \mathrm{ft}^{3} / \mathrm{s}\right)$ prior to agriculture, to $14 \mathrm{~m}^{3} / \mathrm{s}\left(151 \mathrm{ft}^{3} / \mathrm{s}\right)$ after agriculture began in the Big Platte River of Wisconsin. In Coon Creek, Wisconsin, peak discharges were reduced by $45 \%$ after proper agricultural land management practices were implemented in 1940 (Magilligan, 1985). Equations using pre-settlement channel morphology, as well as equations using land use, soils, topography, and climate indicate that peak discharge and peak runoff doubled after European settlement (Knox, 1977).

Fluvial sedimentation has been used as a key to spatial and temporal variability of archaeology sites (Ferring, 1986), as well as assessing the potential for the existence of sites in alluvial settings (Stafford, 1981). Alluvial soils provide age, environmental, and geomorphic contexts for artifacts within the alluvium (Ferring, 1992). Gerrard (1987) subdivides alluvial soils into two main classes: floodplain and terrace soils. Floodplain soils form on floodplains and have new material added incrementally, commonly called cumulic soils (Gerrard, 1987). Terrace soils are those that are flooded only by largemagnitude floods (Baker and others, 1983). Buried soils, or paleosols, may occur within 
either floodplain or terrace soils (Ferring, 1992).

Five factors of soil formation occur in alluvial settings: climate, organisms, parent material, topography, and time (Jenny, 1941). These factors may be either independent of, or dependent on, one another (Fanning and Fanning, 1986). All five of the soil forming factors interact and contribute to the formation of a paleosol. Paleosols indicate a period of accretion after a period of non-deposition (Holliday, 1992). Intervals of geomorphic stability (non-deposition) promote soil-profile development, while intervals of overbank accretion interrupt soil development (Ferring, 1992). The rate of soil-profile development is inversely proportional to sedimentation rates (Ferring, 1992). Paleosols, in turn, indicate the potential accumulation of artifacts from possibly several occupations over a long period of time (Holliday, 1992). "Rapid sedimentation promotes superposition of artifacts and features that resulted from serial occupations of sites...Conversely, slow deposition during multiple episodes of occupation results in accumulation of archaeological debris as mixed assemblages either on paleo-surfaces or within stratigraphic units." (Ferring, 1986: 264).

Magnetic susceptibility contributes a significant amount of information to this study. The electrons in a mineral align in the presence of an external magnetic field. The magnetic properties of molecules are controlled by the spin of their electrons (Klein \& Hurlbut, 1999). A spinning electron generates a magnetic field as it moves around its orbit, producing a magnetic moment (Klein \& Hurlbut, 1999). The magnetic moments of paired electrons nullify each other, whereas unpaired electrons produce an effective magnetic moment (Klein \& Hurlbut, 1999). The intensity of the magnetic moment is dependent on the number of unpaired electrons in the atom (Klein \& Hurlbut, 1999). A 
diamagnetic substance is made up of atoms in which all electrons are paired.

Diamagnetic substances have no magnetic moment and are, therefore, non-magnetic (Klein \& Hurlbut, 1999). Ferrimagnetic substances (magnetite and other members of the spinel series) are more magnetic, whereas paramagnetic minerals (olivine, augite) are less magnetic. Ferromagnetic (metallic iron) substances have similar properties to ferrimagnetic substances.

Magnetic susceptibility can be measured in several ways with the best choice of instrument depending on the nature of the studied sediments. Magnetic discontinuities are better suited for "active" instruments which directly record magnetic susceptibility by applying a magnetic field to the material and measuring the response of the material from its own magnetic properties (Clark, 1990). Examples of "active" instruments are the MS2 Bartington and a Bison Model 3101. These types of instruments are useful in floodplain sediments. "Passive" instruments, a magnotometer, measure the local shape of the Earth's magnetic field and show the effect that the magnetic properties of the underlying material has on the Earth's magnetic field (Clark, 1990). This method is non-discrete and will measure effects from all nearby materials, but will not detect signals of individual stratigraphic units. Passive measurements are therefore inappropriate for describing alluvial stratigraphy (Clark, 1990).

The magnetic susceptibility of soils is an important parameter and provides detailed information for archaeologists (Clark, 1990). Increases in magnetic susceptibility may show variations in parent material or soil development. Parent materials containing high amounts of iron-bearing minerals will consequently have high magnetic susceptibility, whereas nonmagnetic materials will act as dilutants, resulting in 
parent materials containing mainly nonmagnetic materials having low magnetic susceptibility (Tite, 1972). Magnetic susceptibility peaks measured in soil profiles may indicate differences in iron oxides. A strongly ferromagnetic maghemite (gamma- $\mathrm{Fe}_{2} \mathrm{O}_{3}$ ) has been shown to produce magnetic susceptibility peaks in soil profiles (Tite and Mullins, 1971). There is a significant increase or spike in magnetic susceptibility of topsoils compared to underlying subsoils because of the accumulation of relatively insoluble iron oxides in topsoil (Clark, 1990). Because of its high magnetic susceptibility, magnetic susceptibility can be used to identify eroded topsoil as a sediment source in areas of reworked deposits (Clark, 1990). A sequence of magnetic susceptibility peaks can provide a time-lapse record of landscape evolution (Clark, 1990). Alteration of soils due to human activities (disposal of wastes and hearth fires) or natural phenomenon (decay of organic matter during wet periods and forest fires) will cause alteration of weakly ferromagnetic hematite (alpha- $\mathrm{Fe}_{2} \mathrm{O}_{3}$ ) to strongly ferromagnetic maghemite (gamma- $\mathrm{Fe}_{2} \mathrm{O}_{3}$ ), causing peaks in magnetic susceptibility in soil profiles (Clark, 1990, Tite, 1972, Tite and Mullins, 1971).

\section{STUDY BASIN}

The proposed construction of a reservoir in Randolph and Gilford counties in North Carolina led to the investigation of cultural resources along a section of Deep River and Muddy Creek (Fig. 1). Piedmont Triad Regional Water Authority of Greensboro, North Carolina, has been assessing conditions at this site for the last 27 years (Lautzenheiser and others, 1997). Since 1970, several cultural surveys have been completed in the proposed area in accordance with the National Historic Preservation Act 


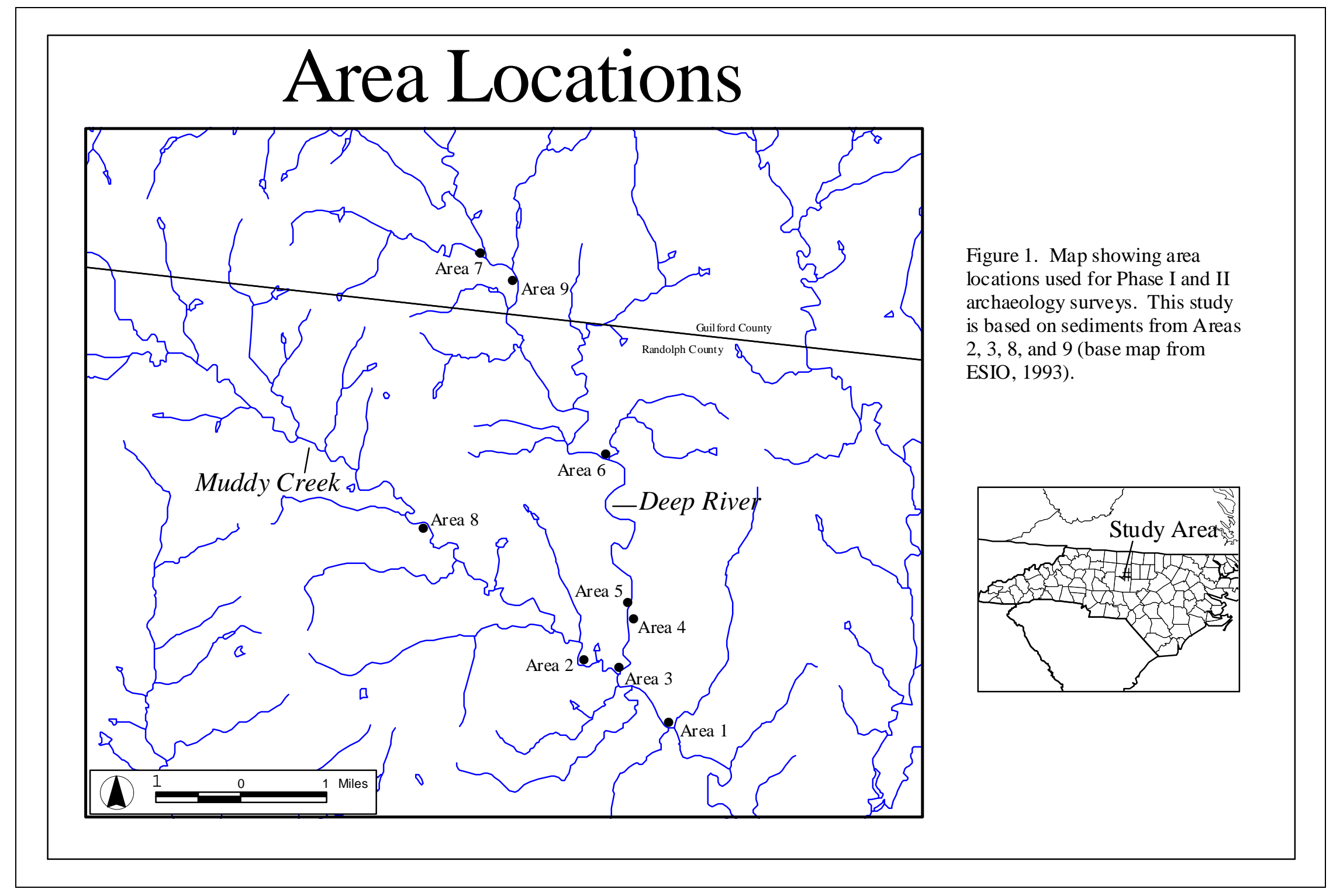


of 1966 (Lautzenheiser and others, 1997). This act requires that any federally funded or permitted construction project include an archaeological investigation to determine if there are areas eligible for the National Register of Historic Places (Lautzenheiser and others, 1997). The latest study (Lautzenheiser and others, 1997) is the most extensive and comprehensive geoarchaeological survey done within the floodplain of these two streams. A preliminary survey of archaeological resources was done as a Phase I assessment completed in April 1997. The Phase I survey was an overview of the study area to locate buried surface horizons and identify potential site locations. A Phase II survey, completed in April 1998, concentrated on specific site characterization and detailed mapping of sites identified in the Phase I survey. The areas numbered 1 through 9 in Figure 1 were selected for the Phase I archaeological survey. Areas 2, 3, 8, and 9 were tested during the Phase I and II archaeological investigations and are used in this study. These four sites were chosen based on data recovered from the two-phase investigation.

Deep River and Muddy Creek flow south-southeast from near High Point to Ashboro, North Carolina, through the Piedmont physiographic province. The upstream, northernmost reaches of the two rivers flow through granitic rocks, whereas the more southern reaches flow through terrain dominated by metavolcanic rocks, heavily intruded by southwest-northeast trending diabase dikes (Lautzenheiser and others, 1997). The confluence of the two rivers is about $8 \mathrm{~km}(5 \mathrm{mi})$ north of Randleman, North Carolina, where the route of Deep River changes to a more north-south orientation. The sinuous path of the Deep River and Muddy Creek, in the study area, is generally controlled by the interaction between diabase dike intrusions and the country rock (Seramur, personal communication). The river meanders only locally where large floodplain areas are 
present. Muddy Creek tends to follow a more sinuous path than Deep River. Within the study area, Deep River has a gradient of $4.7 \mathrm{ft} / \mathrm{mi}$ (0.0009) and Muddy Creek has a gradient of about $8.6 \mathrm{ft} / \mathrm{mi}$ (0.0016) (Lautzenheiser and others, 1997). Stream-gauge records in Randleman show flood magnitudes up to 567 cms (20,000 cfs) on Deep River (US Geological Survey, 1997).

Geonetics Corporation sampled organics for carbon $14\left({ }^{14} \mathrm{C}\right)$ dates and artifacts were collected by Coastal Carolina Research (Lautzenheiser and others, 1997). Datable artifacts consisted mainly of pottery and lithics. The artifacts and the ${ }^{14} \mathrm{C}$ dates were used to help establish chronology within the floodplain stratigraphy of each area (Lautzenheiser and others, 1997). The geologic history of the floodplain extends beyond the middle Archaic period and possibly into the Paleo-Indian Period (Table 1) (Lautzenheiser and others, 1997).

\begin{tabular}{|l|r|}
\hline \multicolumn{1}{|c|}{ Period or Sub-Period } & \multicolumn{1}{c|}{ Approximate Ages } \\
\hline Paleo-Indian Period & 15,000 to 10,000 B.P. \\
\hline Archaic Period & 10,000 to 3,000 B.P. \\
\hline Early Archaic Sub-Period & 10,000 to 8,000 B.P. \\
\hline Middle Arachic Sub-Period & 8,000 to 5,000 B.P. \\
\hline Late Archaic Sub-Period & 5,000 to 3,000 B.P. \\
\hline Woodland Period & 3,000 to 850 B.P. \\
\hline Early Woodland Sub-Period & 3,000 to 2,400 B.P \\
\hline Middle Woodland Sub-Period & 2,400 to 1,600 B.P. \\
\hline Late Woodland Period & 1,600 to 850 B.P. \\
\hline
\end{tabular}

Table 1. Approximate ages for periods and sub-periods of Indian occupations.

Five prehistoric periods have been documented in North Carolina and historic records indicate early European occupation began as early as the 1700s. Woodland artifacts are dominant in the floodplain sites within the study area, whereas Archaic artifacts dominate sites on terraces and slopes (Lautzenheiser and others, 1997). Three large historic mill 
sites are located along Deep River and many smaller water-powered mill sites are scattered throughout the drainage basin (Lautzenheiser and others, 1997).

\section{AREA 2}

Area 2 is located within a meander bend east of Muddy Creek. The floodplain in this area is $150 \mathrm{~m}$ wide and $500 \mathrm{~m}$ long (Fig. 2). Meander scars and two distinct terraces occur within the floodplain (Lautzenheiser and others, 1997). Sediments, from within a depression along Muddy Creek, indicate lateral migration of the creek produced a sequence of abandoned levees across the floodplain (Lautzenheiser and others, 1997). The floodplain is capped by coarse sand to silty sand, and a paleosol is located at approximately $70 \mathrm{~cm}$ depth (Lautzenheiser and others, 1997). Late-Woodland Mississippian artifacts occur within the paleosol and in the overlying sands (Lautzenheiser and others, 1997). Trench 1 in Area 2 is located on a levee and has $80 \mathrm{~cm}$ of historic sediments, whereas Trench 7 was dug in a more distal position adjacent to a terrace and has only $50 \mathrm{~cm}$ of historic sediments (Fig. 2).

AREA 3

Area 3 is located on the inside of a bend of Deep River, just south of the confluence of Muddy Creek and Deep River (Fig. 3). The river enters Area 3 through a narrow valley. The river bends to the east in this southern reach, following a bedrock contact between volcanic tuffs and volcanic flows (Lautzenheiser and others, 1997). A 


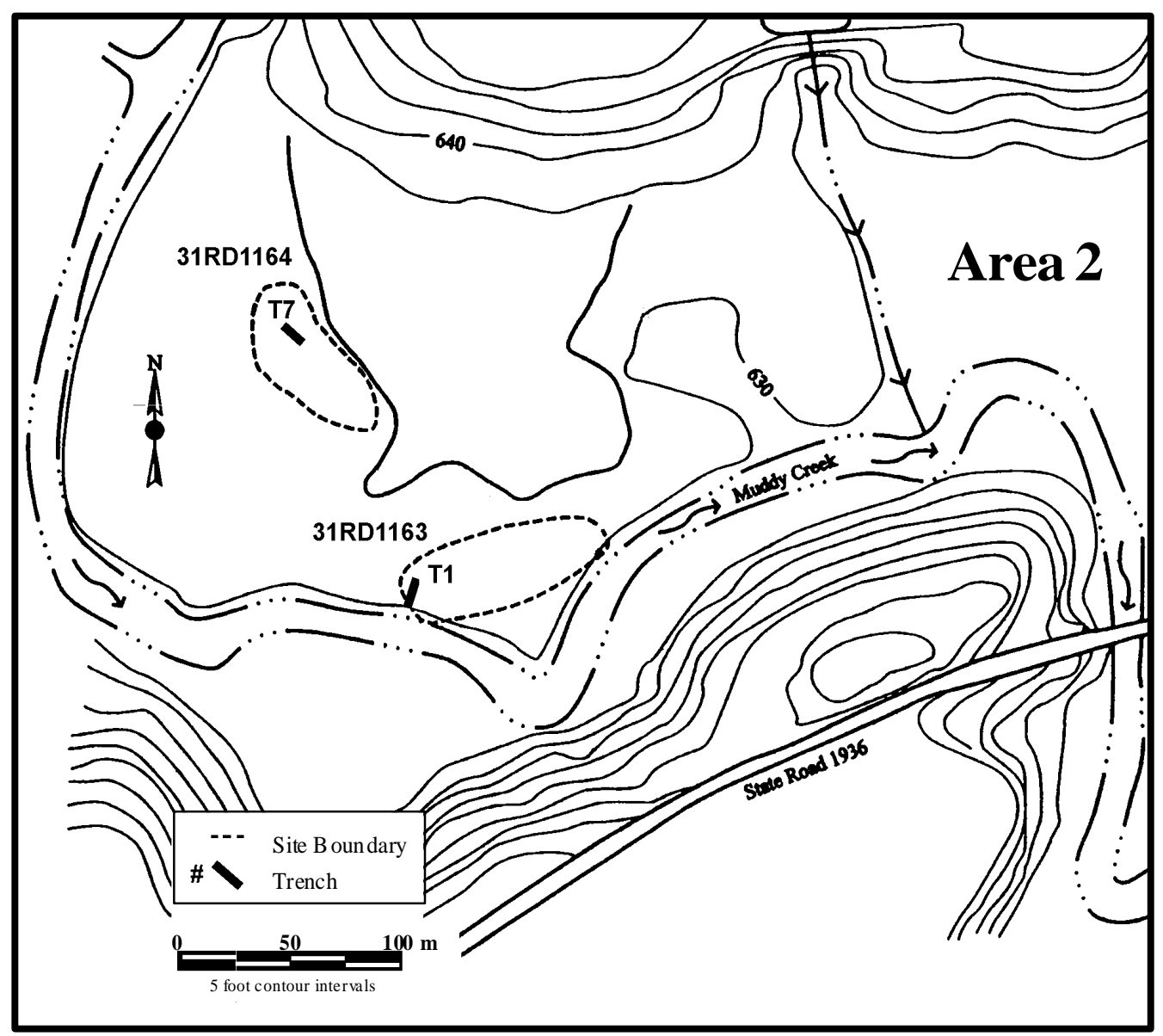

Figure 2. Detailed map of area 2. Archaeology site locations are identified as well as trench locations (Modified from Reid and others, 1998). 


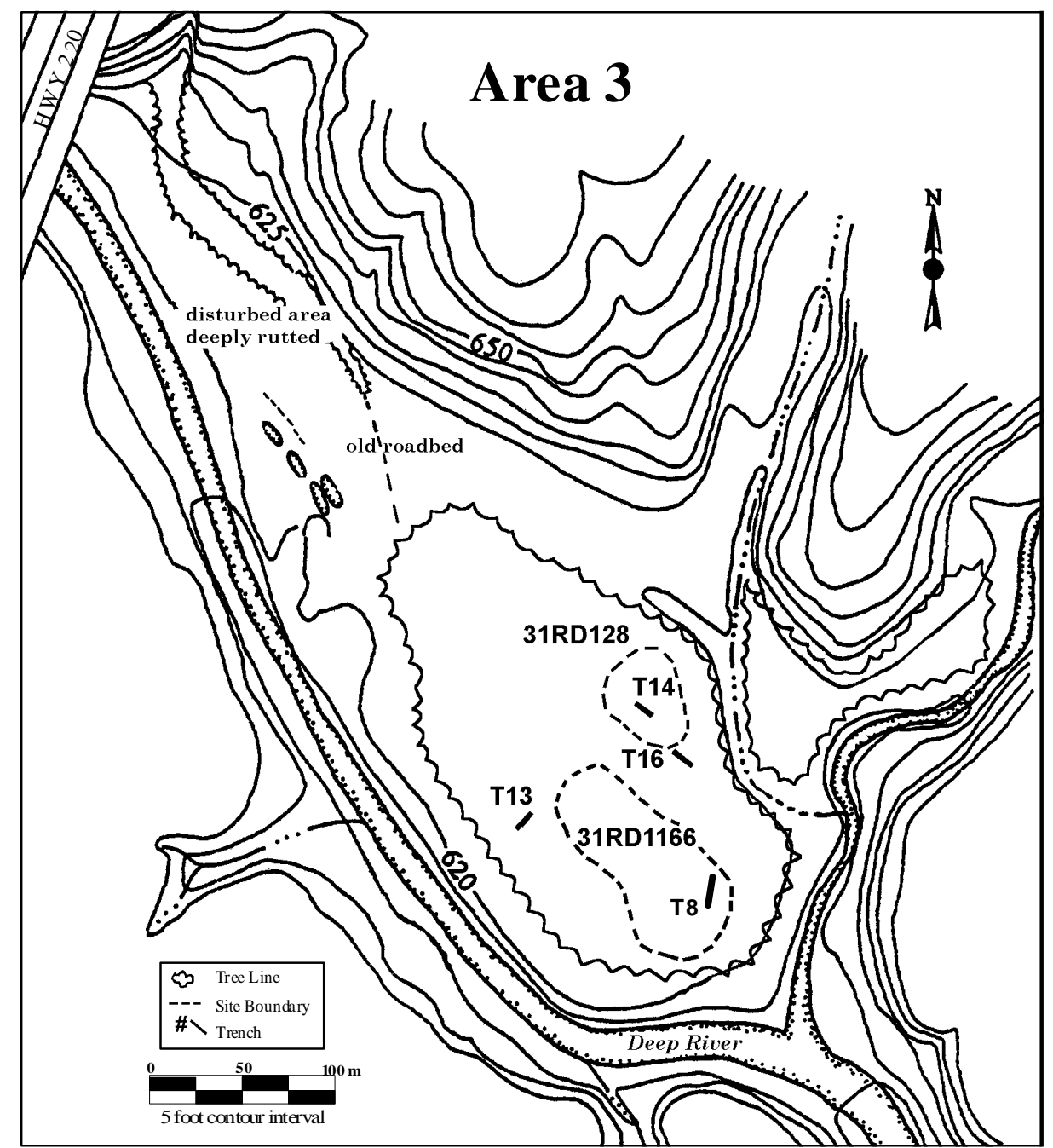

Figure 3. Map of area 3 with trench locations. A rea 3 is located just south of the confluence of Deep River and Muddy Creek (Modified from Lautzenheiser and others, 1997). 
tributary from the west enters the Deep River at the southern end of the area. A welldefined levee, parallel to the river, is continuous along Deep River and Muddy Creek in Area 3. Northwest-southeast trending ridges and swales also parallel the river in Area 3. A discontinuous paleosol occurs at a depth of $50 \mathrm{~cm}$ over most of the floodplain (Lautzenheiser and others, 1997). A discontinuity in the paleosol occurs at the northwest-southeast linear ridges. Artifacts of unidentified age occur within the paleosol (Lautzenheiser and others, 1997).

\section{AREA 8}

Area 8 is located on the inside of a meander, adjacent to Muddy Creek (Fig. 4). The outside of the meander is a steep bedrock valley wall. Levees occur along the length of Area 8. A lobate feature that extends from the southwest hills (Lautzenheiser and others, 1997) defines the upper surface in Area 8. A paleosol occurs at depths between $39 \mathrm{~cm}$ and $50 \mathrm{~cm}$ on the main floodplain, whereas the paleosol occurs at $25 \mathrm{~cm}$ depth on low terraces (Lautzenheiser and others, 1997). Portions of the paleosol show evidence of erosion (Lautzenheiser and others, 1997). Massive fine to medium sands occur above the paleosol (Lautzenheiser and others, 1997). Late-Woodland Uwharrie artifacts occur just above the paleosol on the main floodplain (Lautzenheiser and others, 1997).

\section{AREA 9}

Area 9 is a narrow bottomland, 60 to 100 meters in width, which is located on the inside of a wide bend of Deep River (Lautzenheiser and others, 1997) (Fig. 5). A welldeveloped levee occurs along the $1100 \mathrm{~m}$ length of the bottomland (Lautzenheiser and 


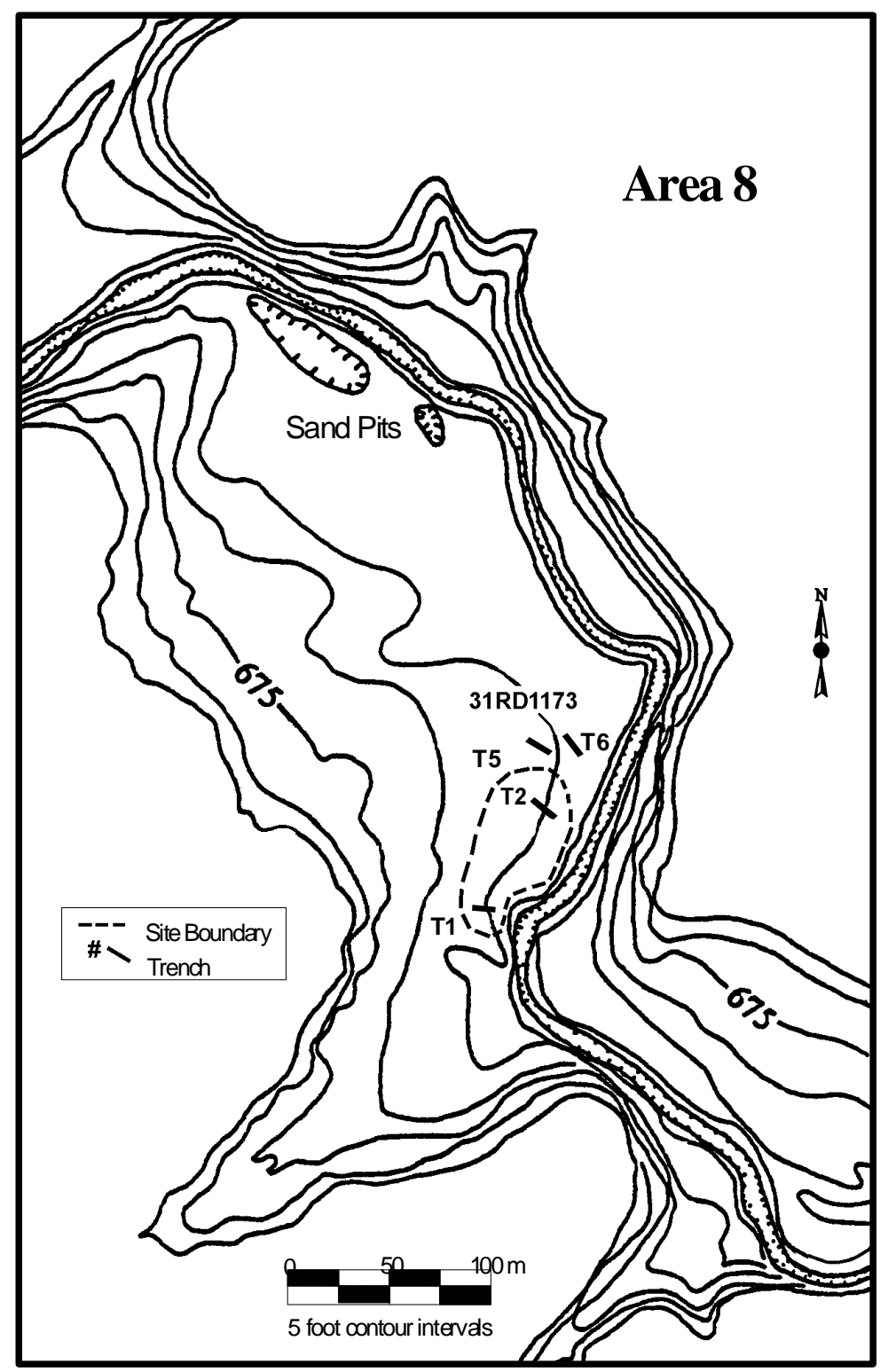

Figure 4. Field location of Area 8. Area 8 is a narrow floodplain located along Muddy Creek (modified from Lautzenheiser and others, 1997). 


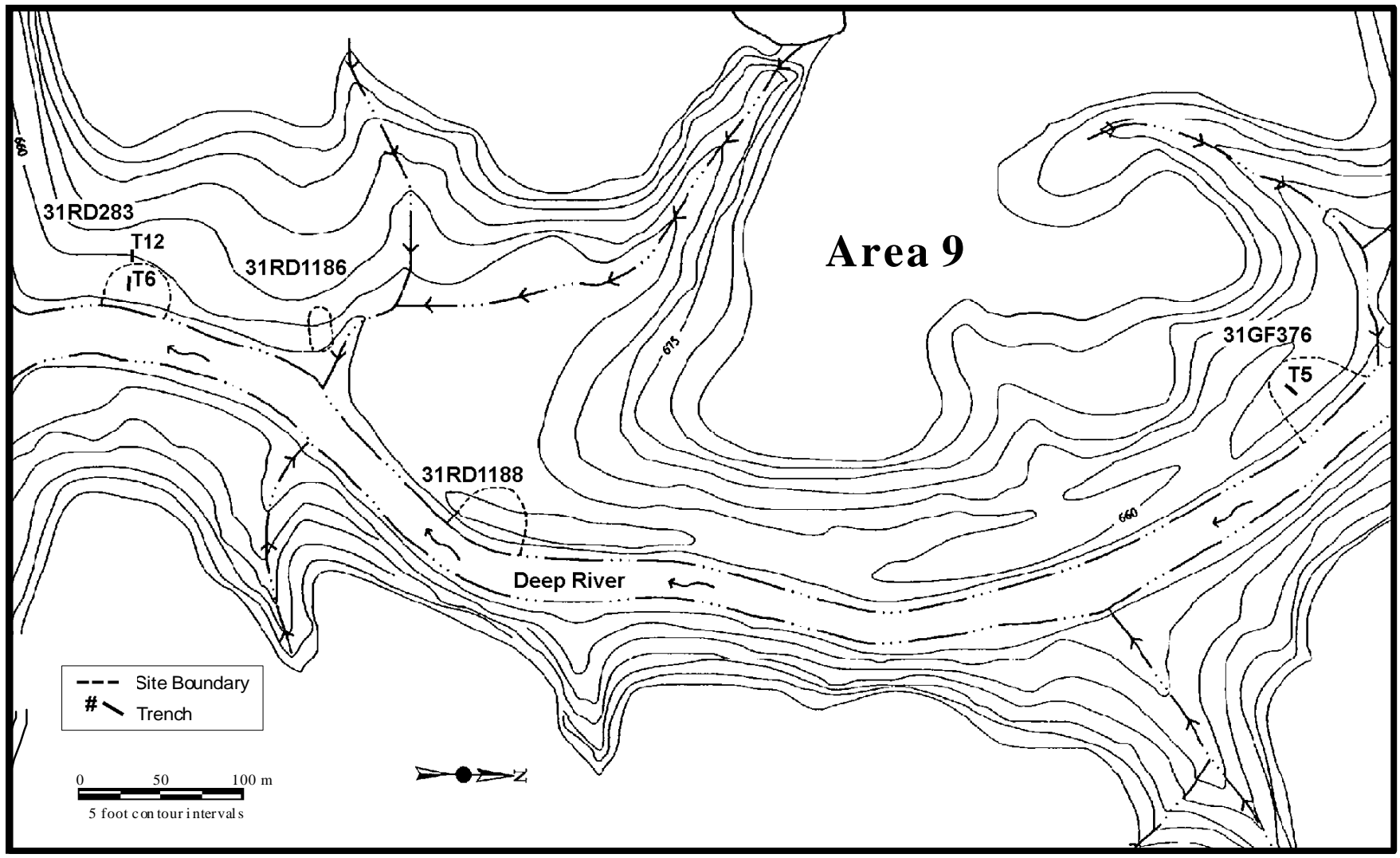

Figure 5. Four known archaeology sites and three trenches from Area 9, were used in this study. Several unnamed tributaries enter from the east and west into Deep River at Area 9 (Modified from Reid and others, 1998). 
others, 1997). The valley bottom, in this reach, is comprised of several small floodplains that occur between hillslopes at the confluence of tributaries and are connected by levees on narrow terraces (Lautzenheiser and others, 1997).

Three surfaces occur above the river in Area 9 (Lautzenheiser and others, 1997). The upper surface is composed of saprolite with a thin veneer of colluvium, topped by a thin cap of flood sediments (Lautzenheiser and others, 1997). The intermediate surface shows a paleosol at approximately $25 \mathrm{~cm}$ depth with overlying massive sands (Lautzenheiser and others, 1997). Artifacts occur in the paleosol and overlying sands (Lautzenheiser and others, 1997). Trenches in the lower surface revealed massive sands above a paleosol at approximately $55 \mathrm{~cm}$ depth (Lautzenheiser and others, 1997). An archaeological feature of undetermined age occurs below the paleosol, $82 \mathrm{~cm}$ below the surface of the lowermost landform (Lautzenheiser and others, 1997).

\section{RESEARCH METHODOLOGY}

\section{Field Methods}

Fourteen trenches in four floodplain sites were sampled and tested in order to analyze historic and prehistoric sediment. Backhoe trenches were used to expose floodplain soils. Trench locations were based on data recovered from the Phase I archaeological testing program. In most cases, standard Soil Taxonomy (Soil Survey Staff, 1987) was used for detailed descriptions of soil profiles. Descriptions included depth to stratigraphic breaks, texture, structure, color, $\mathrm{pH}$, and pedogenic features (Appendix 1). However, only color and stratigraphic breaks were described for several trenches on account of limited time in the field. Stratigrapic units in each soil profile 
were sampled at a $10-\mathrm{cm}$ interval, taken to the lab and analyzed for magnetic susceptibility, loss on ignition, mineralogy, and particle-size characteristics.

\section{Laboratory Methods}

Sediment samples underwent several preparatory steps before any analyses were performed. The samples were first dried for $24 \mathrm{hrs}$ at $95^{\circ} \mathrm{C}$, after which they were disagregated. Bulk magnetic susceptibility was measured using a Bison Model 3101 Magnetic Susceptibility Meter. The meter reads apparent susceptibility to the nearest $10,000 \times 10^{-6} \mathrm{CGS}$ units (Bison Instruments, 1970). Procedures for this analysis are given in Appendix 2.

Percent volatile material was determined from a bulk sediment sample using the Leco Proximate Analyzer. This procedure provides information on the relative abundance of organic matter in the sample and is similar to an organic-carbon analysis. The percent volatile material is indicative of percent organic matter in the sample.

Particle-size analysis of the sediment was done in two steps. The sample was separated into particle-size fractions using standard sieving techniques (Bell, 1986). The silt-clay fraction was analyzed using a SediGraph model 5100 (SediGraph, 1989). Sand, silt, and clay ( $<-1$ to 4 phi, $<4$ to $7 \mathrm{phi}$, and $<8$ phi (Folk, 1980)) percentages were obtained from particle-size distributions based on sieve data and a cumulative percent curve generated by the SediGraph. General procedures are described in Appendix 3.

Mineralogy of the bulk sample was determined using X-ray diffraction and elemental analysis was preformed by $\mathrm{x}$-ray fluorescence. Samples for x-ray diffraction and $\mathrm{x}$-ray fluorescence were prepared as follows: 
1. Samples were crushed to $200 \mathrm{mesh}(0.074 \mathrm{~mm})$,

2. A representative sample was removed,

3. Samples were pressed onto a $40-\mathrm{mm}$ plastic disk using 15 ton total load. X-ray diffraction was preformed using a Phillips PW 1800 diffractometer with $\mathrm{CuK} \alpha$ single crystal monochromatic radiation in step scan mode from $4^{\circ} 2 \theta$ to $75^{\circ} 2 \theta$ at 1 second/step. The data were quantified using the GM Quant procedure (Johnson and Smith, 1991). X-ray florescence was preformed on a Phillips PW 1450/80 spectrometer using Phillips no-standards program. The percent volatile analysis, $\mathrm{x}$-ray florescence, and x-ray diffraction was preformed at the West Virginia University Mineralogy Lab, located in White Hall, on the University's main campus in Morgantown, West Virginia.

\section{RESULTS}

Sediments from the four floodplain areas are grouped into two categories for analysis: historic sediment and prehistoric sediment. This study focused on comparing the sedimentology of the two age groups rather than comparing the characteristics of the four floodplain areas. This approach is appropriate because the four floodplains have similar bedrock lithologies and soils in their drainage basins.

Dated artifacts and ${ }^{14} \mathrm{C}$ analysis indicate each floodplain contains a paleosol that corresponds to an age of about B.P. 250-1150 (Lautzenheiser and others, 1997). The artifacts associated with the paleosol were mostly Late Woodland, Dan River culture (B.P. 850-1600). The paleosol was used to differentiate historic sediments from prehistoric sediments; sediments above the paleosol are described herein as historic sediments. The paleosol and the underlying sediments are considered prehistoric 
sediments. Variations in historic sediment thickness are related to geomorphic position. In general, the blanket of historic sediment thins away from the main river channel.

\section{Particle-size and Magnetic Susceptibility}

Particle-size analysis can provide information about the mode of sediment deposition as well as the depositional energy regime. Sediment types were delineated using statistical methods (Appendix 4). Overall, sediments in the study area exhibit a bimodal particle-size distribution (Fig. 6). Based on stratigraphic position relative to the paleosol, historic sediments tend to be slightly coarser and less well sorted than prehistoric sediments (Fig. 7).

Comparison of the two populations show that the historic and prehistoric sediment are significantly different based on the sample correlation coefficient, $r$, and the $t$ test. The relationship between the two variables is expressed through the statistic $r$ (in this case magnetic susceptibility and particle size), whereas $t$ tests the significance of $r$. The correlation coefficient, $r$, is a unitless number and ranges from -1.0 to +1.0 (Davis, 1973). A correlation coefficient of +1.0 shows a perfect correlation between two variables and a correlation coefficient of -1.0 indicates that there is an inverse relationship between the variables. A value of 0.0 indicates that there is no relationship between the variables (Davis, 1973). The relationship between the two variables, $r$, is an estimation that can be applied to the entire population of which there is only a finite sample (Davis, 1973). There is of course, a certain amount of uncertainty involved with estimation. The uncertainty is expressed as a significance level. The significance level 


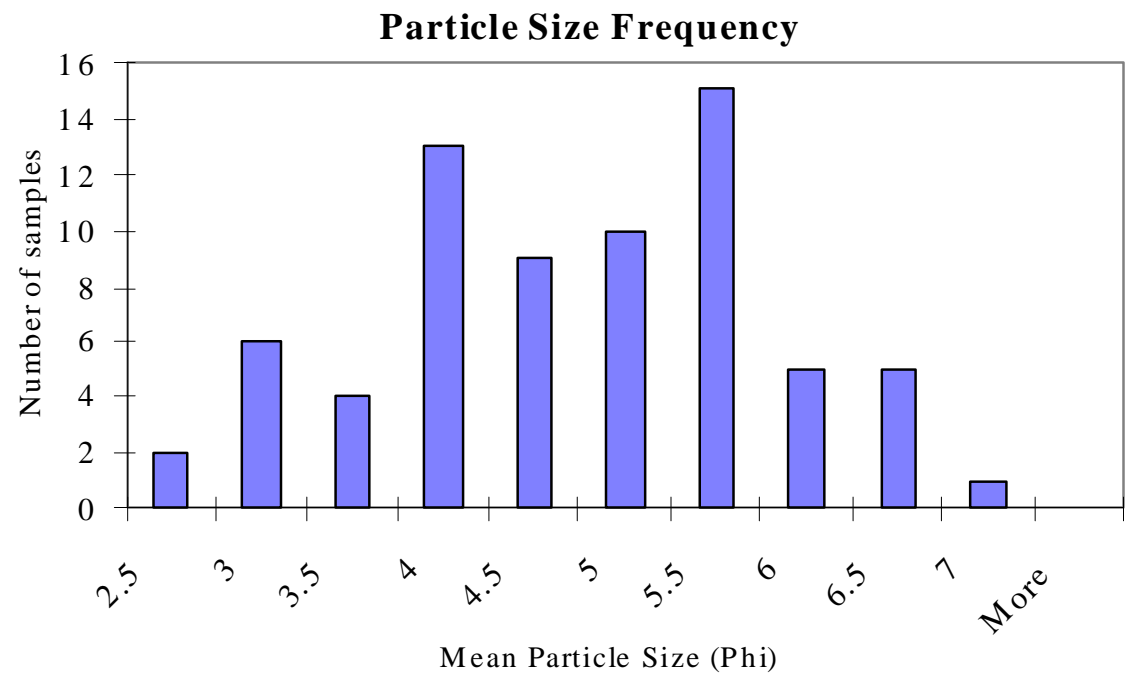

Figure 6. Particle size frequency chart showing a bimodal distribution. This histogram of mean particle-size shows $4-4.5$ phi and $5.5-6.0$ phi to be the most common particle-size.

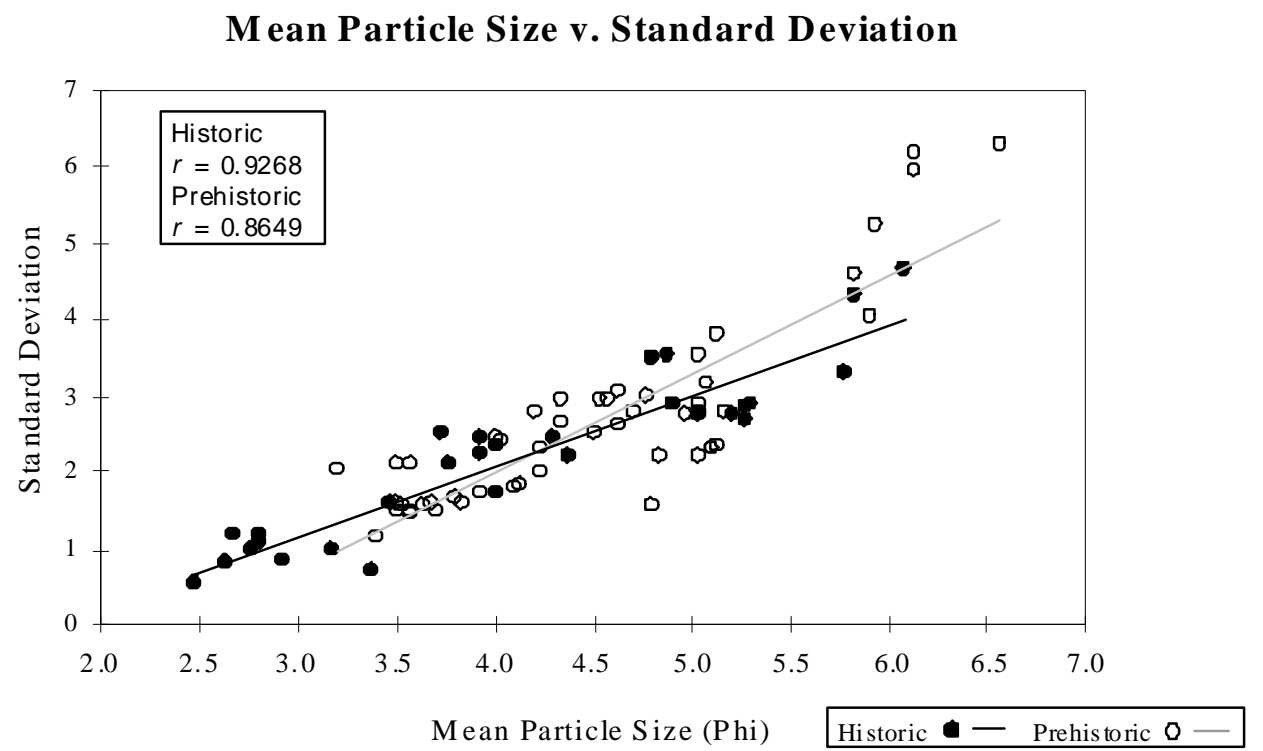

Figure 7. The relationship between mean and standard deviation for the historic and prehis toric sediments. Historic sediments are slightly coarser and less well sorted than the prehistoric sediments. 
reflects how closely the estimation will be to the actual value if every possible sample could be measured (Davis, 1973). A significance level of 0.05 (5\%) was used for this study, which means that one in twenty samples will produce an answer not predicted by the $r$-value (Davis, 1973). A $t$ test determines if the two variables used to calculate $r$ are independent (Davis, 1973). This measurement is based on the number of samples in the population. The $t$ test will show if $r$ is significantly different from zero and if a nonzero value for $r$ has been calculated because of random sampling (Davis, 1973). The test statistic is calculated by the following equation:

$$
\begin{gathered}
t=\frac{r \sqrt{n-2}}{\sqrt{1-r^{2}}} \\
r=\text { correlation coefficient } \\
n=\text { number of samples } \\
\text { (from Davis, 1973) }
\end{gathered}
$$

The statistical $t$ value for, the historic and prehistoric populations, for the graphic mean with 75 degrees of freedom is 0.6629 . Critical values of $t$ for a two-tailed test with 75 degrees of freedom and 5\% level of significance are +0.2642 and -0.2642 . The fact that the value of $t$ for the mean lies outside the critical region indicates that the historic sediments have a significantly different mean than the prehistoric sediments, and therefore represent different populations.

A textural diagram (Fig. 8) helps to show the subtle differences in historic and prehistoric sediments. The historic sediments include several samples with approximately $100 \%$ sand content, whereas the prehistoric sediments include several samples with clay percentages greater than $25 \%$. However, most samples in either population contain $>45 \%$ sand. 


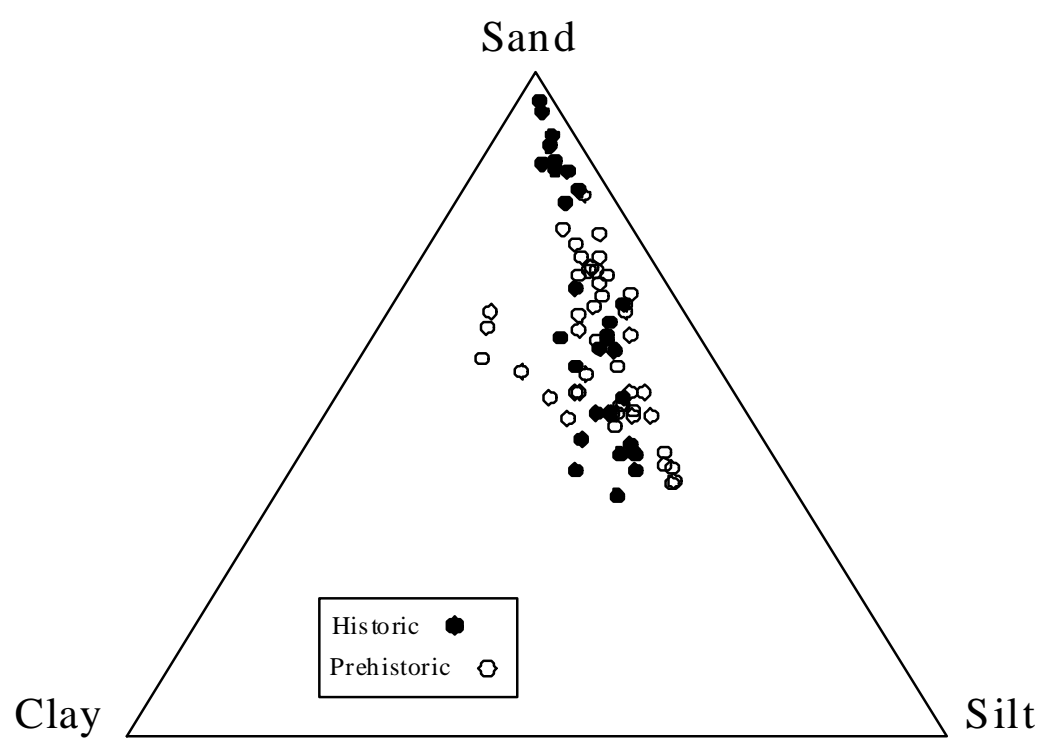

Figure 8 . Tertiary diagram showing historic sediments tend to be more sandy while prehistoric sediments tend to be slightly more clayey.

Magnetic susceptibility values for historic sediments range from $27 \times 10^{-6} \mathrm{cgs}$ units to $81 \times 10^{-6} \mathrm{cgs}$ units with an average of $46.3 \times 10^{-6} \mathrm{cgs}$ units. Comparably, values for prehistoric sediments range from $29 \times 10^{-6} \mathrm{cgs}$ units to $88 \times 10^{-6} \mathrm{cgs}$ units with an average of $46.0 \times 10^{-6} \mathrm{cgs}$ units (Appendix 5). Although, these two populations are very similar, different trends in magnetic susceptibility occur when they are compared to particle-size. Figure 9 shows bivariate plots of magnetic susceptibility and phi intervals of historic and prehistoric sediments. The relationship between magnetic susceptibility and particle-size for historic and prehistoric sediments is simplified when considering the $r$-values of regression lines for the bivariate plots (Table 2). A positive $r$-value indicates the regression line slope is positive and therefore has a positive relationship between 
9a. Magnetic Susceptibility v. \% Very Coarse Sand

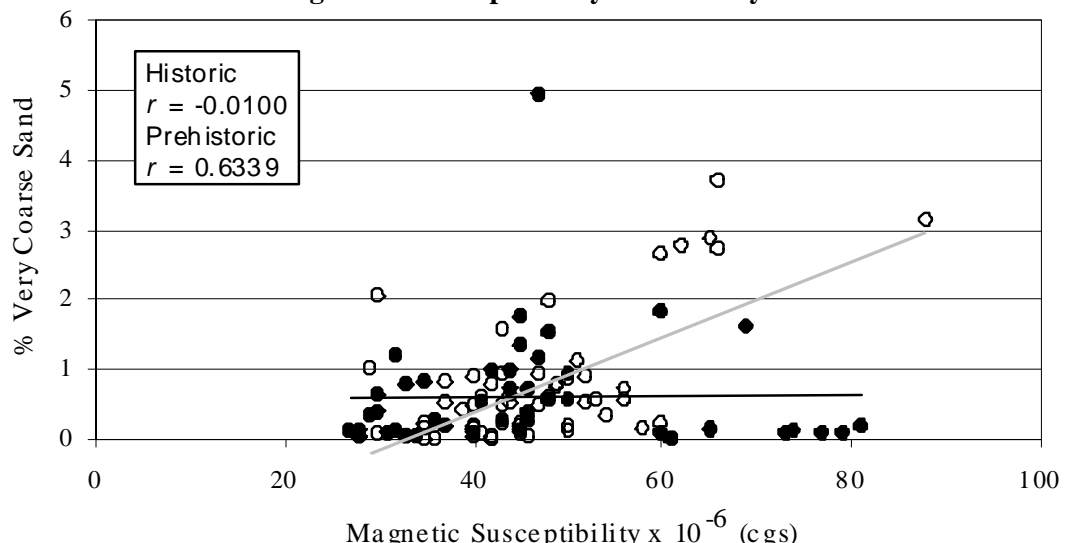

Historic - Prehistoric $0-$

9b. Magnetic Susceptibility v. \% Coarse Sand

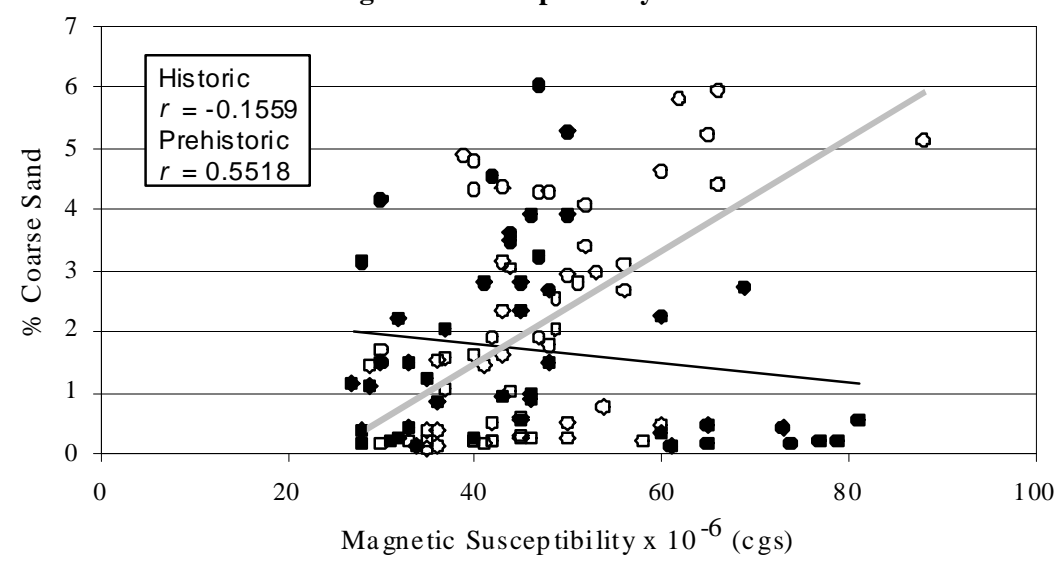

His toric - Prehistoric $0-$

9c. Magnetic Susceptibility v. \% Medium Sand

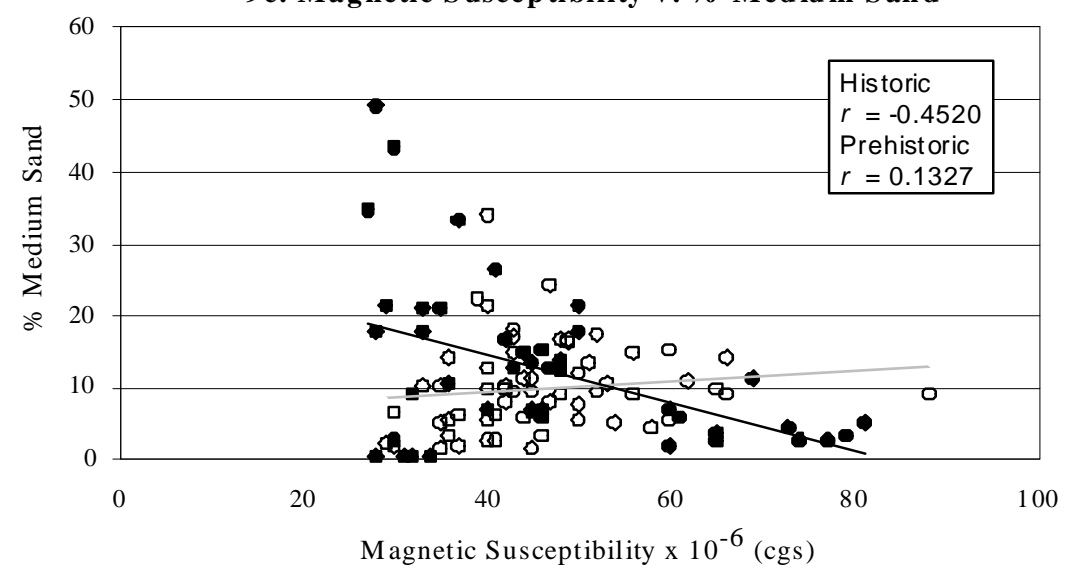

Historic - Prehistoric $0-$

Continued... 
Continued...

9d. Magnetic Susceptibility v. \% Fine Sand

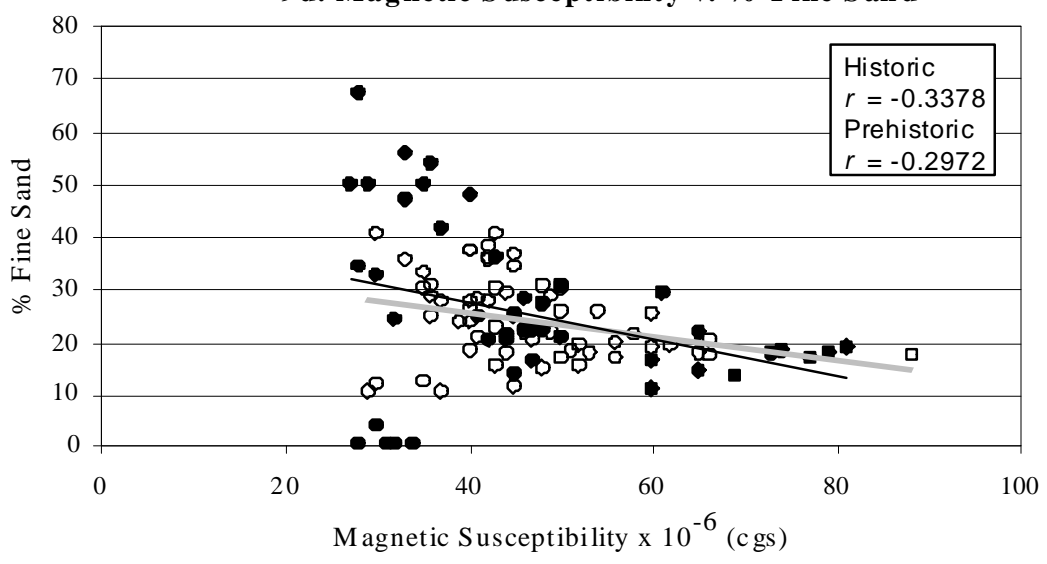

Hist oric $\bullet-$ Prehistoric $0-$

9e. Magnetic Susceptibility v. \% Very Fine Sand

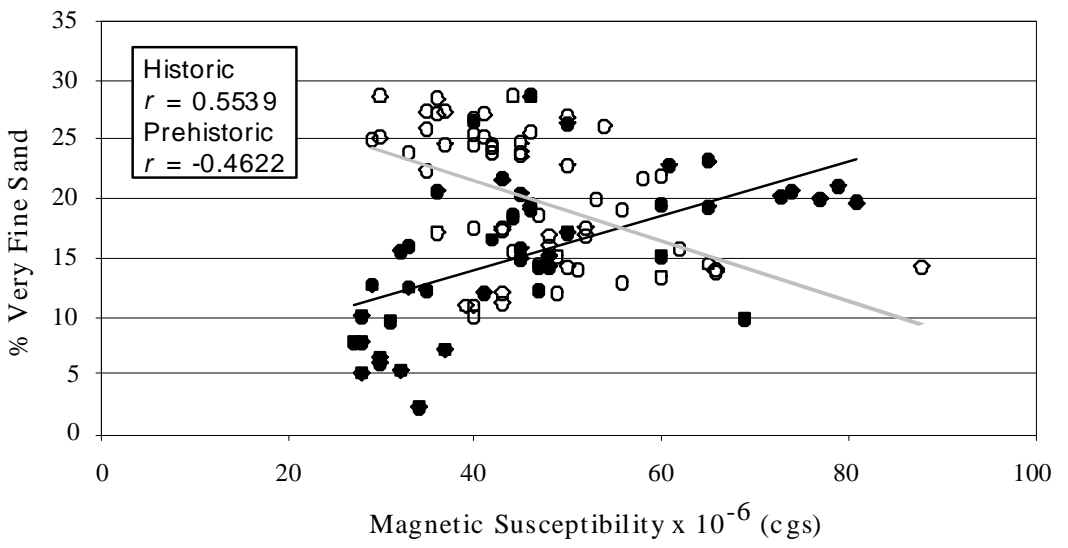

Historic - Preh is toric $0-$

9f. Magnetic Susceptibility v. \% Coarse Silt

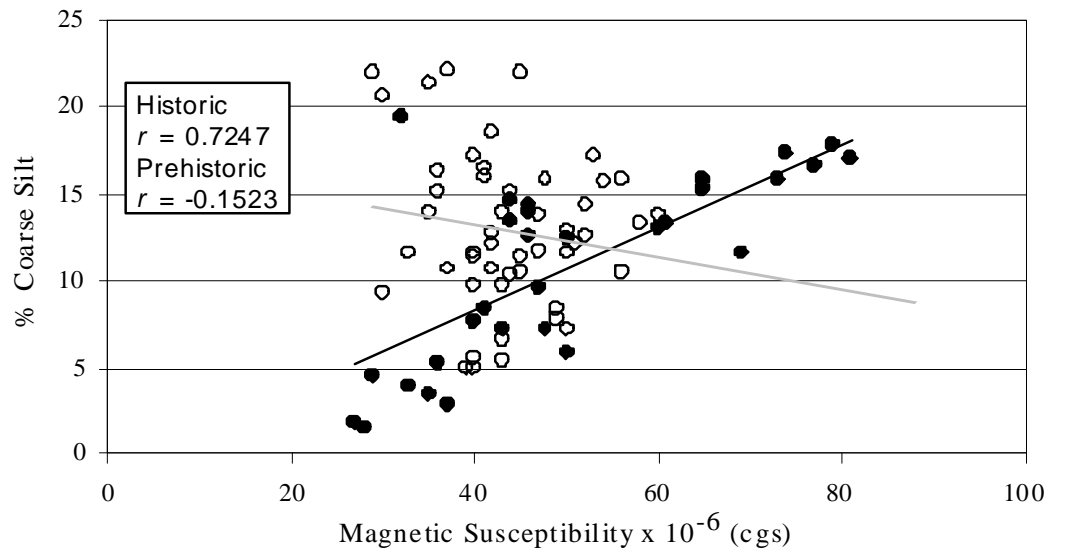

Historic $\bullet-$ Prehistoric $0-$ 


\section{Continued...}

9g. Magnetic Susceptibility v. \% Medium Silt

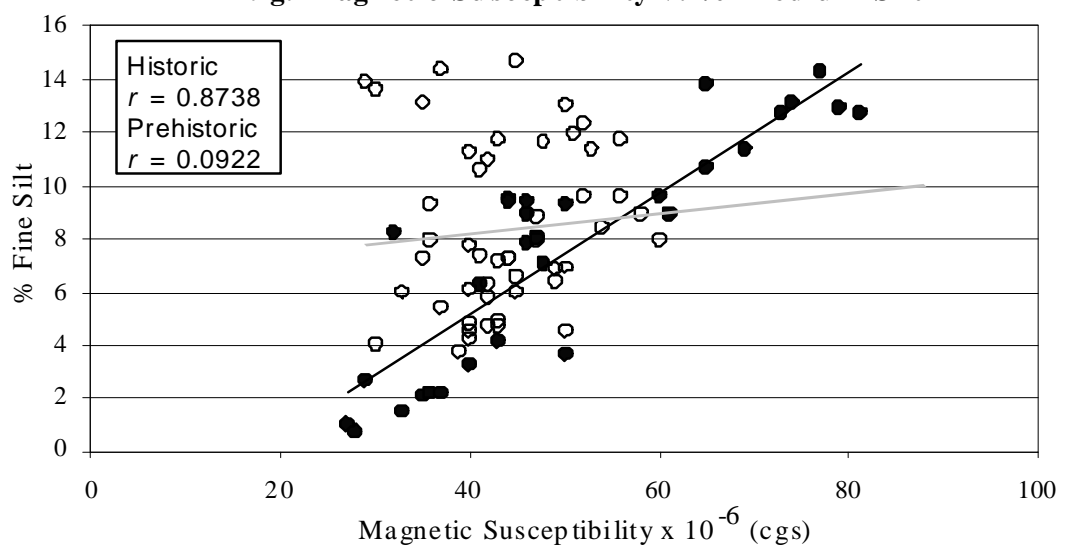

Historic $\bullet-$ Prehistoric $0-$

9h. Magnetic Susceptibility v. \% Fine Silt

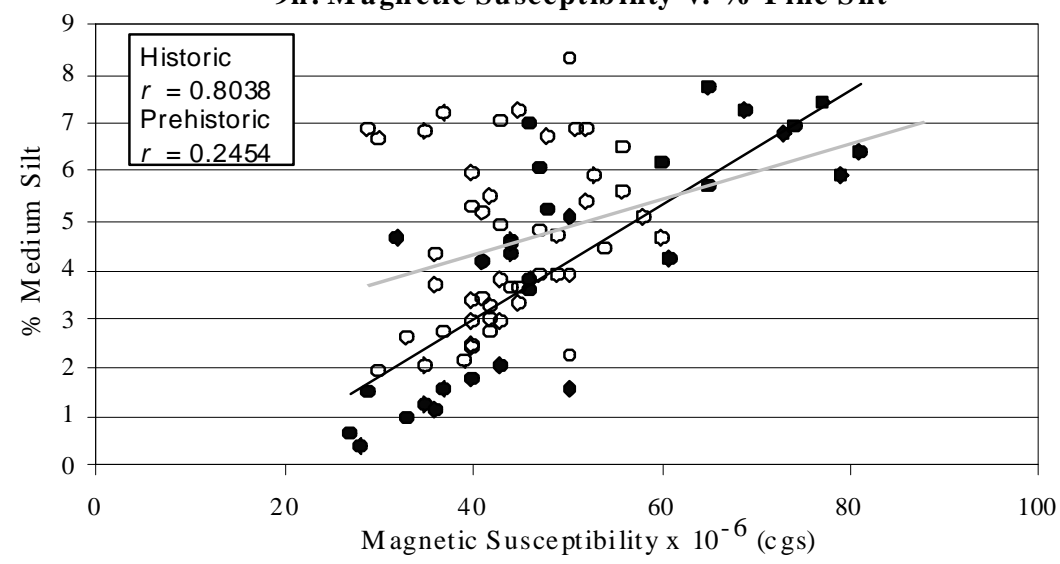

Historic - Prehistoric $0-$

9i. Magnetic Susceptibility v. \% Very Fine Sand

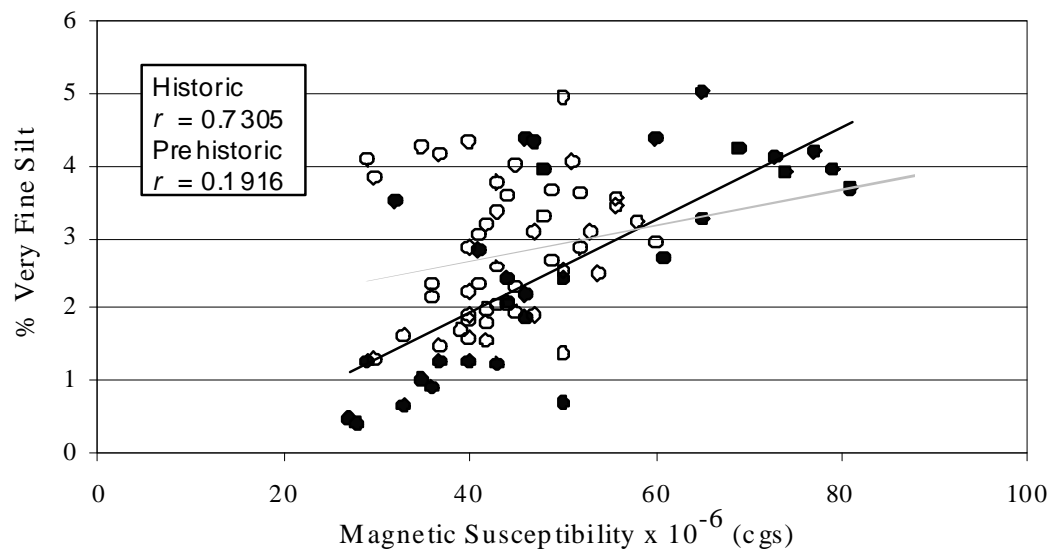

His toric $\bullet-$ Prehistoric $0-$ 
Continued...

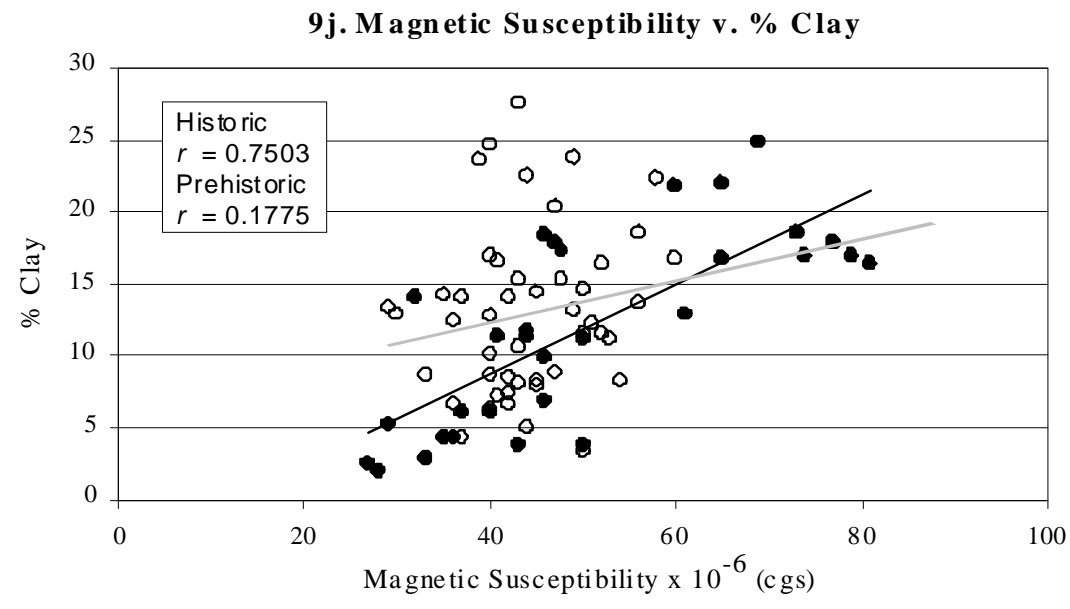

His toric - Prehistoric $\mathrm{O}-$

Figure 9. Phi interval v. Magnetic Susceptibility. Regression lines show trends in particle size intervals for historic and prehistoric sediments. The $r$ values are used to describe how well the data correspond to the li near regression line. 


\begin{tabular}{|c|c|c|c|c|c|c|c|c|c|c|}
\hline \multirow[b]{2}{*}{ Particle Size Class } & \multirow[b]{2}{*}{$\# 9$} & \multirow[b]{2}{*}{ Phi Interval } & \multicolumn{4}{|c|}{ Historic Sediments } & \multicolumn{4}{|c|}{ Prehistoric Sediments } \\
\hline & & & $\begin{array}{c}r \text { Value } \\
\text { MS v. particle } \\
\text { size class }\end{array}$ & $\begin{array}{c}\text { Number of } \\
\text { Samples }\end{array}$ & $\mathrm{t}$ Value & $\begin{array}{l}2 \text { Tailed } \\
\text { Probability }\end{array}$ & $\begin{array}{c}r \text { Value } \\
\text { MS v. particle } \\
\text { size class }\end{array}$ & $\begin{array}{c}\text { Number of } \\
\text { Samples }\end{array}$ & Value & $\begin{array}{l}2 \text { Tailed } \\
\text { Probability }\end{array}$ \\
\hline \multirow{10}{*}{$\begin{array}{l}\text { very coarse sand } \\
\text { coarse sand } \\
\text { medium sand } \\
\text { fine sand } \\
\text { very fine sand } \\
\text { coarse silt } \\
\text { medium silt } \\
\text { fine silt } \\
\text { very fine silt } \\
\text { clay }\end{array}$} & $\mathrm{a}$ & $<-1$ to 0 & -0.0100 & 58 & 0.0789 & $* 0.9406$ & 0.6339 & 45 & 5.3742 & 0.0000 \\
\hline & $\mathrm{b}$ & $<0$ to 1 & -0.1559 & 58 & 1.1810 & $* 0.2426$ & 0.5518 & 45 & 4.3389 & 0.0001 \\
\hline & $\mathrm{c}$ & $<1$ to 2 & -0.4520 & 58 & 3.7919 & 0.0004 & 0.1327 & 45 & 0.8777 & $* 0.3850$ \\
\hline & $\mathrm{d}$ & $<2$ to 3 & -0.3378 & 58 & 2.6856 & 0.0095 & -0.2972 & 45 & 2.0407 & 0.0474 \\
\hline & $\mathrm{e}$ & $<3$ to 4 & 0.5539 & 58 & 4.9784 & 0.0000 & -0.4622 & 45 & 3.4175 & 0.0014 \\
\hline & $\mathrm{f}$ & $<4$ to 5 & 0.7247 & 49 & 7.2103 & 0.0000 & -0.1523 & 30 & 0.8155 & $* 0.4217$ \\
\hline & $\mathrm{g}$ & $<5$ to 6 & 0.8738 & 49 & 12.3213 & 0.0000 & 0.0622 & 30 & 0.4899 & $* 0.6280$ \\
\hline & $\mathrm{h}$ & $<6$ to 7 & 0.8038 & 49 & 9.2631 & 0.0000 & 0.2454 & 30 & 1.3392 & $* 0.1913$ \\
\hline & $\mathrm{i}$ & $<7$ to 8 & 0.7305 & 49 & 7.3329 & 0.0000 & 0.1916 & 30 & 1.0328 & $* 0.3105$ \\
\hline & $\mathrm{j}$ & $<8$ & 0.7503 & 49 & 7.7815 & 0.0000 & 0.1775 & 30 & 0.9543 & $* 0.3481$ \\
\hline
\end{tabular}

Table 2. Summary of $r$ values generated from plots in Figure 9. $t$-values and probability values for relationships between particle size and magnetic susceptibility were calculated to validate

visual trends seen in the plots. A probability of $<0.05$ indicates a good relationship between parameters. 
magnetic susceptibility and particle size interval, whereas a negative $r$-value indicates a negative slope and therefore an inverse relationship between magnetic susceptibility and particle size interval. In general, the slope of the line (either positive or negative) describes the relationship between magnetic susceptibility and particle size, while an $r$ value shows the relative strength of the relationship between the two variables. The validity of an $r$-value is dependent on the number of samples in the population and the $t$ statistic described previously. Relationships between historic and prehistoric sediments are shown in Figure 10 by using statistical $r$-values of regression lines in the bivariate plots of Figure 9. Table 2 shows the $t$ statistic and the $r$-values for the sample populations, whereas Figure 10 illustrates the variations in magnetic susceptibility in response to particle-size for historic and prehistoric populations making it easier to compare the two populations.

There are distinct differences between relationships seen in historic and prehistoric populations. The $r$-values for historic sediments show strong relationships between magnetic susceptibility and particle-size. However, there are significant variations in $r$-values for individual particle-size intervals (Table 2). The $r$-values for medium sand and fine sand are negative, whereas all finer fractions of historic sediments have a positive $r$-value. Although the relationships with very fine sand, coarse silt, fine silt, very fine silt and clay are significant for historic sediments, the strongest significant relationship with magnetic susceptibility exists within the medium silt fraction.

The $r$-values for prehistoric sediments are significantly different than the $r$-values for the historic sediments. Significant relationships between magnetic susceptibility and 
$r$ value v. Particle Size

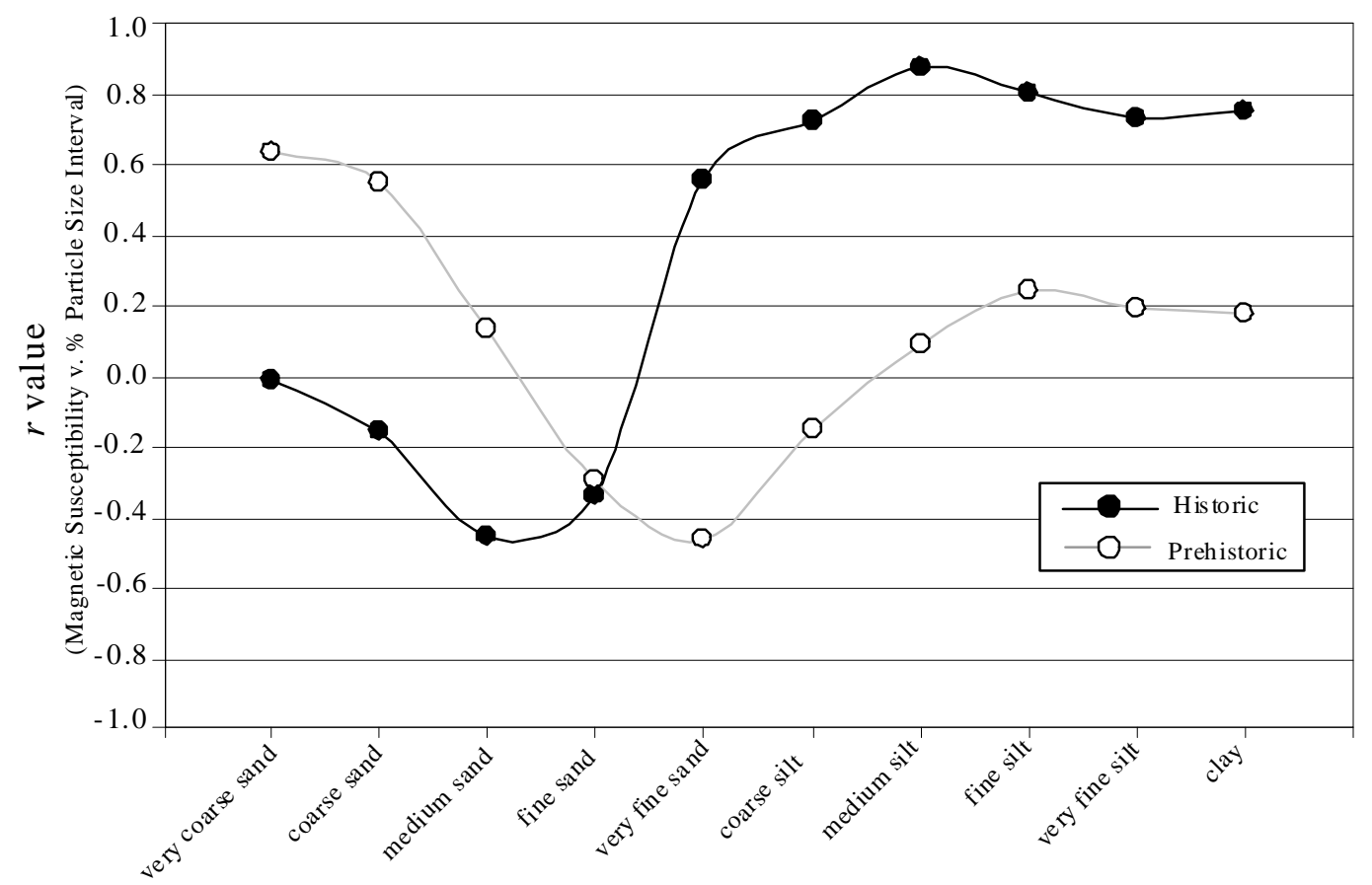

Figure 10. Plot of $r$ values for relations hip between particle size and magnetic susceptibility. A positive value indicates that particle size and magnetic susceptibility have a positive relationship, whereas a negative value indicates that particle size and magnetic susceptibility have an inverse relationship. In general, the closer the value of $r$ is to 1.0 or -1.0 the stronger the relationship is between magnetic susceptibility and particle size. The strength of the relationship is actually dependent on the number of samples, the $t$ value, and probability value of the regression lines shown in Figure 9. Specific $t$ values and probability values can be found in Table 2 .

particle-size only exist in the very coarse sand, coarse sand, fine sand, and very fine sand intervals. Positive $r$-values occur in the very coarse sand fraction and the coarse sand fraction of the prehistoric sediments. The high positive $r$-values indicate an increase in magnetic susceptibility in prehistoric sediments containing a large very coarse sand fraction or coarse sand fraction. However, the fine and very fine sand fractions of the prehistoric sediments are inversely related to magnetic susceptibility. The negative $r$ value indicates an increase in magnetic susceptibility in sediments with a low percentage 
of fine sand and very fine sand.

There are different particle-sizes that correspond to high or low magnetic susceptibility when comparing historic sediments with prehistoric sediments. For historic sediments, the medium sand interval corresponds with a decrease in magnetic susceptibility, whereas for prehistoric sediments the very fine sand interval corresponds with a decrease in magnetic susceptibility. Relationships between particle size and high magnetic susceptibility vary between historic and prehistoric sediments. Historic sediments have strong positive relationship for the very fine sand, coarse silt, medium silt, fine silt, very fine silt, and clay intervals. However, prehistoric sediments show a negative correlation with the very fine sand interval.

\section{Organic Matter}

Soil organic matter consists of dead plant and animal material, partially decayed and partially resynthesized plant and animal remains, and humus (completely decayed remains) (Stein, 1992). Accumulation of organic matter in the study area is more related to soil genesis than it is organic sedimentation. During sedimentation, a large portion of organic matter is destroyed or washed out of floodplain sediments during high-energy floods. Hence, soil organic matter must accumulate and the process of soil development, i.e. in situ alteration of the parent material, must occur during times of surface stability.

Analyses indicate that percent organic matter is weakly related to mean particlesize, but is not significantly related to magnetic susceptibility (Fig. 11). Organic matter commonly occurs in the form of root masses or translocated fine-grained humus (Stein, 1992). The mean organic content in the historic sediment is $2.56 \%$ (0.66 to $8.64 \%)$, 


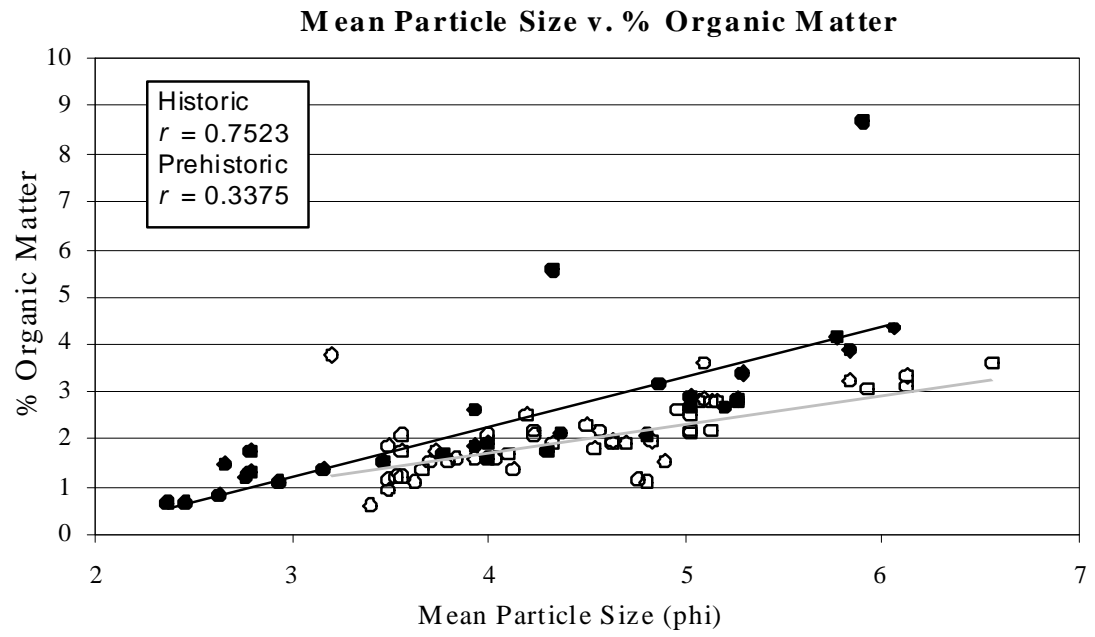

Historic $\bullet-$ Prehistoric $0-$

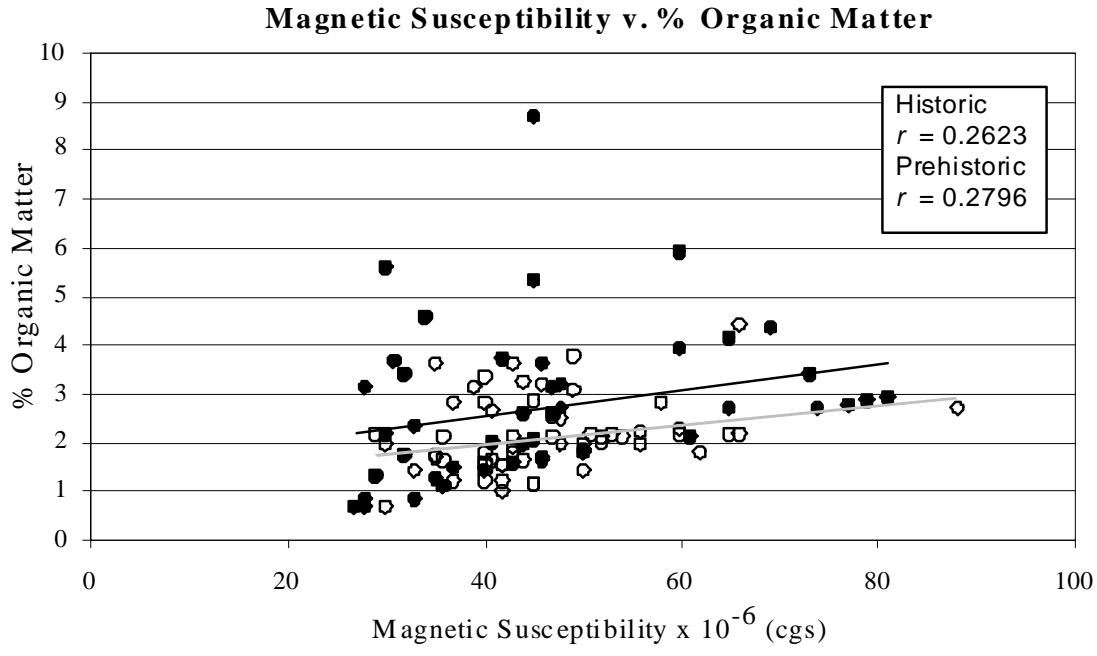

Historic $\bullet-$ Prehistoric $0-$

Figure 11. Organic matter increases as particle-size decreases in both historic and prehistoric sediments. Magnetic susceptibility also increases and particlesize decreases. These trends correspond to trends between particle-size and magnetic susceptibility. 
whereas the mean organic matter in the prehistoric sediment is $2.09 \%(0.62$ to $3.73 \%)$ (Appendix 5).

Organic content increases as mean particle-size decreases in both historic and prehistoric sediments (Fig. 11). Finer sediments are more likely to contain organic matter than coarser sediments because of their lower-energy deposition environment. Humus may coat surfaces of larger grains but becomes attached to clay and silt particles (Stein, 1992). Organic matter would also accumulate more readily in finer sediments because smaller pore spaces would make ground water movement more difficult and fine sediments have a larger surface area for the attachment of organic matter.

According to Gale and Hoare (1991), the addition of organic matter to soils may reduce magnetic susceptibility by acting as a dilutant in accumulations of magnetic minerals. However, organic processes can form magnetic minerals, specifically magnetite (Gale \& Hoare, 1991). Organisms such as bacteria and algae are able to form crystals of magnetite that are released into the system after their death (Gale \& Hoare, 1991). Analysis of the historic and prehistoric sediments shows that magnetic susceptibility has no relationship with organic matter for historic and prehistoric sediments. This lack of correlation between organic matter and magnetic susceptibility may be attributed to the presence of modern plant material. The effects of modern plant material can be seen in outliers of in Figure 11. Samples with greater than about $4 \%$ organic matter can be considered outliers. Outlier samples were generally located near the surface (from 0 to $15 \mathrm{~cm}$ depth), typically in the Ap horizon, where plant remains tend to be introduced in greater quantity and more frequently than would be without agricultural activity. 


\section{Elemental Analyses}

Elemental analysis of each sample was performed by x-ray fluorescence. The xray fluorescence results are reported as percent oxide. This analysis however, does not indicate the oxidation state of the ions of each element. Nine oxides occur in the historic and prehistoric sediments: $\mathrm{Fe}_{2} \mathrm{O}_{3}, \mathrm{MnO}, \mathrm{TiO}_{2}, \mathrm{Na}_{2} \mathrm{O}, \mathrm{SiO}_{2}, \mathrm{Al}_{2} \mathrm{O}_{3}, \mathrm{MgO}, \mathrm{CaO}$ and $\mathrm{P}_{2} \mathrm{O}_{5}$. Trends for all nine oxides are similar for samples in historic and prehistoric populations (Appendix 6). However, distinct trends appear in both historic and prehistoric sediments when percent oxide in a sample is compared to particle-size and magnetic susceptibility of the same sample.

Figures 12 through 15 show changes in $r$-values for each plot of percent oxide versus percent particle-size. Bivariate plots used to generate $r$-values can be found in Appendix 7. An increase in $r$-value corresponds to a positive correlation between particle-size and percent oxide, whereas a decrease in $r$-value reflects an inverse relationship.

Trends seen in $\mathrm{Al}_{2} \mathrm{O}_{3}$ and $\mathrm{Fe}_{2} \mathrm{O}_{3}$ are similar in historic sediments but vary somewhat from one another in prehistoric sediments. Analysis of $\mathrm{Al}_{2} \mathrm{O}_{3}$ and $\mathrm{Fe}_{2} \mathrm{O}_{3}$ indicate that there is an inverse relationship between particle size and magnetic susceptibility in historic samples (Fig. 12). In general, coarser historic sediments have less $\mathrm{Al}_{2} \mathrm{O}_{3}$ and $\mathrm{Fe}_{2} \mathrm{O}_{3}$ oxides.

In the prehistoric sediments, $r$-values $(0.4963$ to -0.5451$)$ indicate an overall decrease in percent $\mathrm{Al}_{2} \mathrm{O}_{3}$ as particle size decreases from coarse sand to very fine silt. However, there is an abrupt change in $r$-value from very fine silt $(-0.5451)$ to clay 

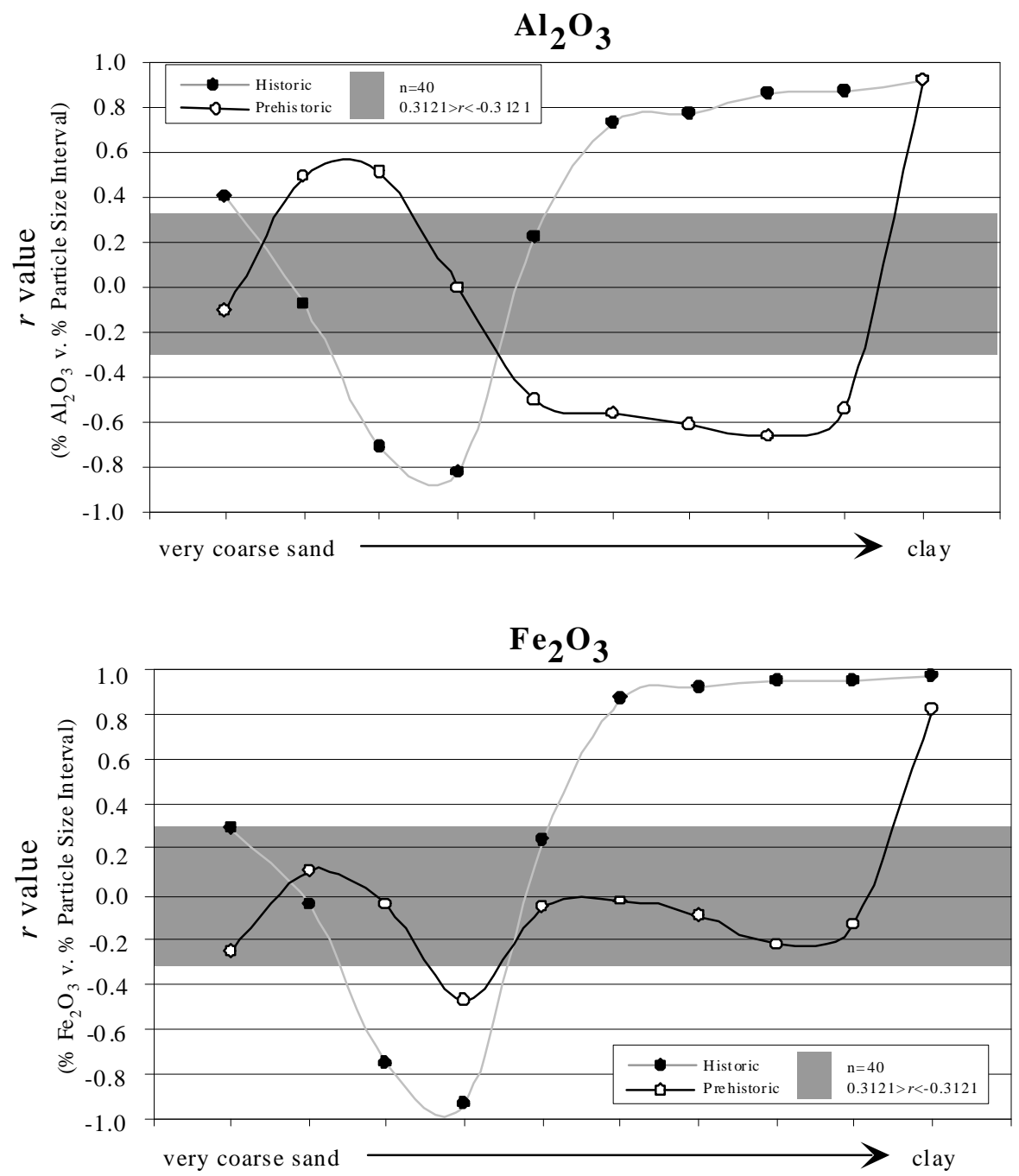

Figure 12. $r$ values calculated for each particle size interval and plotted in descending particle size for $\mathrm{A} 12 \mathrm{O} 3$ and $\mathrm{Fe} 2 \mathrm{O} 3$. The trends seen in historic and prehis toric sediments for the above plots are similar. The finer sediments have a positive relationship with the oxides and the fine sands have an inverse relationship with the oxides for the historic sediments. The clay interval of the prehistoric sediments has a positive relationship with these oxides. The gray band illustrates samples which are not statistically significant. 

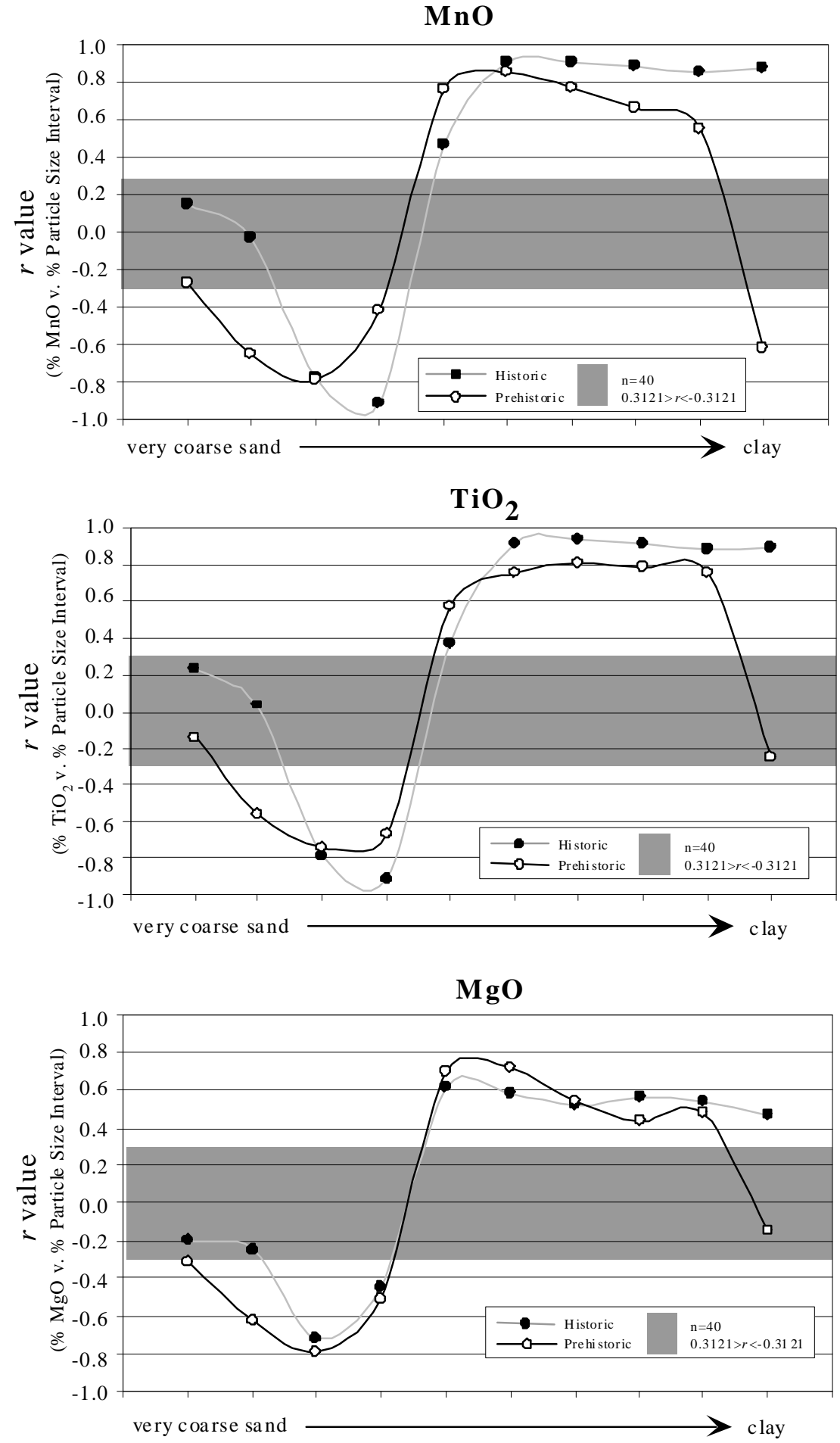

Figure 13. Particle size correlates to percent oxide similarly in the historic sediments for $\mathrm{MnO}, \mathrm{TiO}_{2}$ and $\mathrm{MgO}$. $\mathrm{MnO}$ and $\mathrm{TiO}_{2}$ have similarities in the prehistoric sediments. 

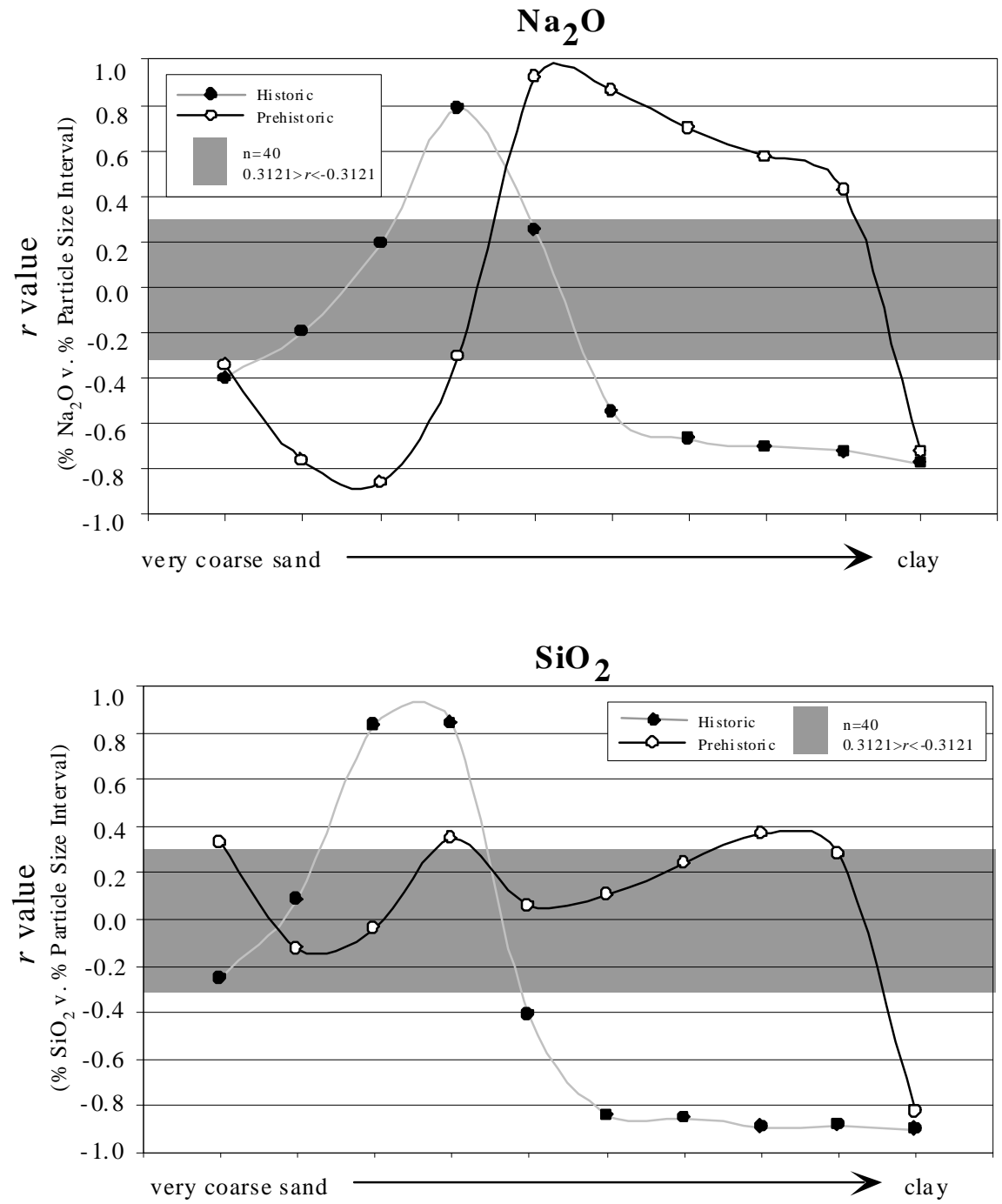

Figure 14. Properties of $\mathrm{Na}_{2} \mathrm{O}$ and $\mathrm{SiO}_{2}$ are similar in the historic sediments. The relationship between particle size and oxide in the prehistoric sediments look similar to those trends seen in $\mathrm{MgO}$. 

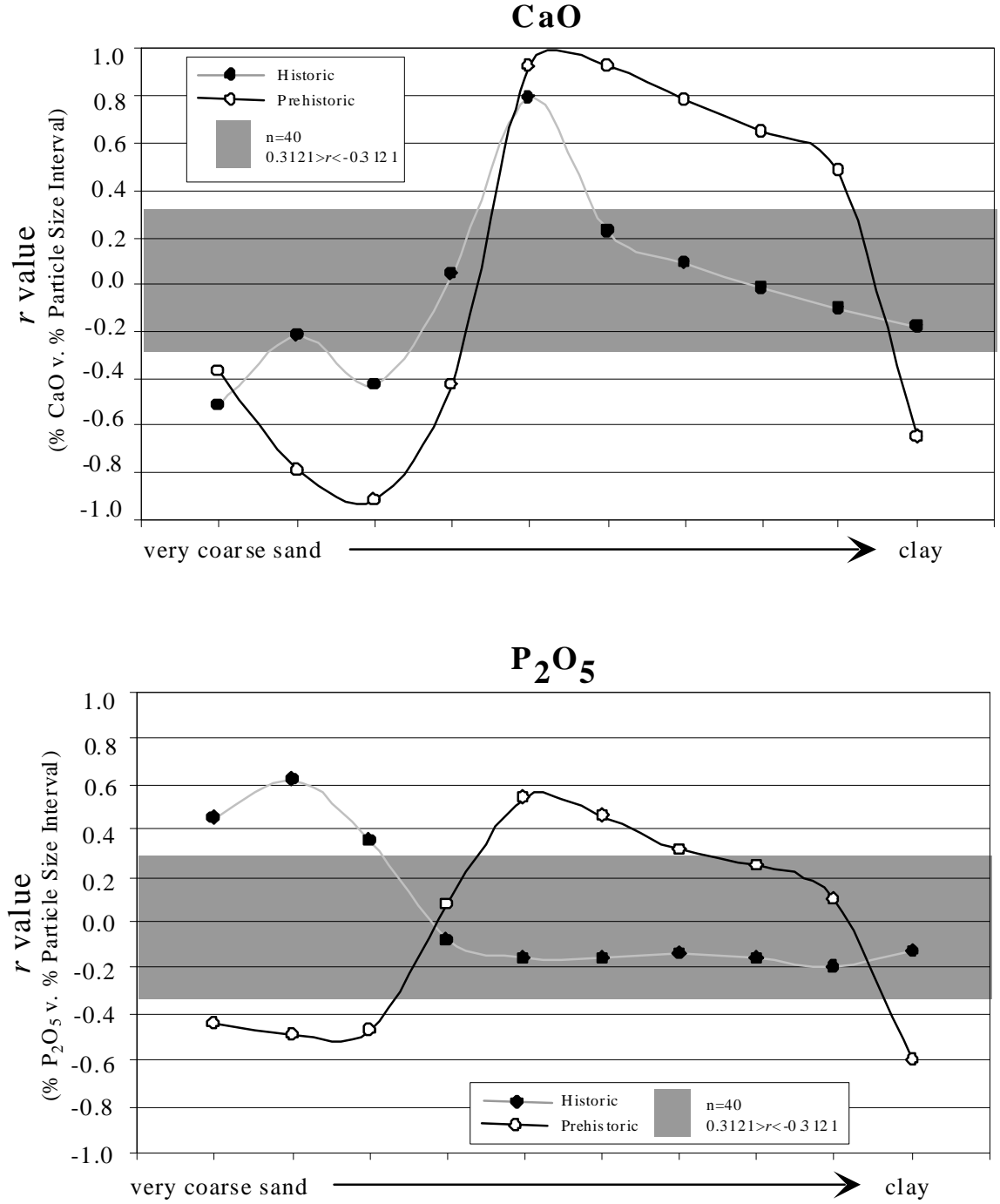

Figure 15. Relationships between between particle size and $\mathrm{CaO}$ and $\mathrm{P}_{2} \mathrm{O}_{5}$. 
(0.9244) suggesting that there is a steep increase in percent $\mathrm{Al}_{2} \mathrm{O}_{3}$ as clay increases in a sample (Fig.12). Comparison of $\mathrm{Fe}_{2} \mathrm{O}_{3}$ and particle size for the prehistoric sediments indicates percent $\mathrm{Fe}_{2} \mathrm{O}_{3}$ in a sample has no relationship to particle-size except in the clay interval. The increase in $r$-value for clay from -0.1304 for very fine silt to 0.8207 indicates that percent $\mathrm{Fe}_{2} \mathrm{O}_{3}$, like $\mathrm{Al}_{2} \mathrm{O}_{3}$, is more abundant in the clay fraction.

Trends in historic and prehistoric sediments in comparing $\mathrm{MnO}, \mathrm{TiO}_{2}$ and $\mathrm{MgO}$ to particle size are somewhat similar (Fig. 13). In both historic sediments and prehistoric sediments, trends show an inverse relationship between the abundance of the three oxides and coarser sediments, indicating that coarser sediment has lower concentrations of $\mathrm{MnO}$, $\mathrm{TiO}_{2}$ and $\mathrm{MgO}$ than do finer sediments. For historic sediments, concentrations of $\mathrm{MnO}$, $\mathrm{TiO}_{2}$ and $\mathrm{MgO}$ are generally high in finer sediments. This trend is the same for prehistoric sediments, except there is an abrupt decrease in the percentages of $\mathrm{MnO}, \mathrm{TiO}_{2}$ and $\mathrm{MgO}$ in the clay interval. $\mathrm{MnO}$ has the strongest inverse relationship with the clay interval $(r=-0.6234)$, whereas $\mathrm{TiO}_{2}$ and $\mathrm{MgO}(-0.2542$ and -0.1490$)$ imply a percentage decrease but do not have a high enough $r$-value to fall in the $5 \%$ level of significance $(0.3121>r<-0.3121)$. The relationships in prehistoric sediments for $\mathrm{MnO}, \mathrm{TiO}_{2}$ and $\mathrm{MgO}$ are opposite from the trends in prehistoric sediments for $\mathrm{Fe}_{2} \mathrm{O}_{3}$ and $\mathrm{Al}_{2} \mathrm{O}$.

Percent $\mathrm{Na}_{2} \mathrm{O}$, from very fine sand to clay, and percent $\mathrm{SiO}_{2}$, from fine sand to clay, generally decreases in historic sediments (Fig. 14). In prehistoric sediments, $\mathrm{Na}_{2} \mathrm{O}$ has an inverse relationship with coarser sediments and a positive relationship with finer sediments, except for the clay interval. $\mathrm{SiO}_{2}$ generally shows no relationship with particle size, except for the clay interval. There is a distinct decrease in abundance of $\mathrm{Na}_{2} \mathrm{O}$ and $\mathrm{SiO}_{2}$ in the clay interval. 
In historic sediments, $\mathrm{CaO}$ has the best relationship with the very fine sand interval (Fig. 15). Values of $r$ from bivariate plots of percent oxide and particle size show that percent $\mathrm{CaO}$ is high in the interval from very fine sand to very fine silt $(0.9243$ to $0.4755)$. In the clay interval, the $r$ values drops to -0.1490 , indicating a decrease in calcium in the clay interval.

Phosphate, $\mathrm{P}_{2} \mathrm{O}_{5}$, shows significant trends in the very coarse sand, coarse sand, and the medium sand intervals, in the historic sediments. The $r$-values for all other particle-size fractions have either weak relationships with particle-size or none at all. This lack of a strong trend could be due to the addition of fertilizers used in modern farming practices. Addition of $\mathrm{P}_{2} \mathrm{O}_{5}$ in this manner would obscure or erase any association of $\mathrm{P}_{2} \mathrm{O}_{5}$ to particle-size because of plowing, infiltration, and/or precipitation of phosphates in the soil profile. In the prehistoric sediments, the percentage of $\mathrm{P}_{2} \mathrm{O}_{5}$ is low in the coarse fractions and the clay interval, and is high only in the very fine sand interval. This trend is similar to the trend seen in $\mathrm{CaO}$.

$\mathrm{Fe}, \mathrm{Mn}$, and Ti are transitional elements, with unpaired electrons in the $3 d$ subshell (Lindsley, 1989, Klien \& Hurlbut, 1999). These elements can have more than one valence state (Lindsley, 1989). The spins of unpaired $3 d$ electrons provide these transition metals with a magnetic moment (Klien \& Hurlbut, 1999). The spin of electrons is mainly responsible for the magnetic properties of the atoms and molecules (Klein \& Hurlbut, 1999). The magnetic moment is proportional to the number of the unpaired spinning electrons (Klein \& Hurlbut, 1999) (Fig. 16). Therefore, $\mathrm{Fe}^{+3}$ and $\mathrm{Mn}^{+2}$, each having five unpaired electrons, are the most magnetic susceptible and, in turn, have a higher magnetic susceptibility value. Bivariate plots show historic sediments with higher 
magnetic susceptibility values to have high $r$ values and, therefore, contain higher percentages of Fe, Mn, and Ti oxides (Fig. 17). However, for prehistoric sediment, $r$ values for magnetic susceptibility and percent oxide fall below the $5 \%$ significance level of +-0.3121 and, therefore, particle size has no significant relationship with Fe, Mn, and Ti in the prehistoric sediments.

$\mathrm{Na}^{+1}, \mathrm{Si}^{+2}$, and $\mathrm{Al}^{+3}$ are diamagnetic ions; (Klein \& Hurlbut, 1999) their net magnetic moment is zero and they are not attracted to a magnet (Klein \& Hurlbut, 1999). Occurrence of these ions would dilute the overall magnetic susceptibility of a sample. Magnetic susceptibility is inversely related to percent $\mathrm{Na}_{2} \mathrm{O}$ and $\mathrm{SiO}_{2}$ in historic sediments (Fig. 18). In general, the magnetic susceptibility of the prehistoric sediments shows no correlation to the sodium or silica content. Aluminum, $\mathrm{Al}_{2} \mathrm{O}_{3}$, has a positive relationship with magnetic susceptibility in historic sediments but the not in prehistoric sediments. The relationship seen in between $\mathrm{Al}_{2} \mathrm{O}_{3}$ and magnetic susceptibility in the historic sediments may be directly related to the clay particle size interval.

The remaining oxides, $\mathrm{MgO}, \mathrm{CaO}$ and $\mathrm{P}_{2} \mathrm{O}_{5}$, are not strongly correlated with magnetic susceptibility (Fig. 19). Poor correlation between these three oxides and magnetic susceptibility can be attributed to several different factors. One factor is anthropogenic addition of materials that may obscure or change natural trends between particle-size and magnetic susceptibility. Addition of other materials is mainly through the addition of fertilizers used in farming. Another factor may be associated with the $\mathrm{x}-$ ray fluorescence analysis. It is not known which mineral species these ions are associated with. The ions may be small portions of several different magnetic or non-magnetic minerals. 


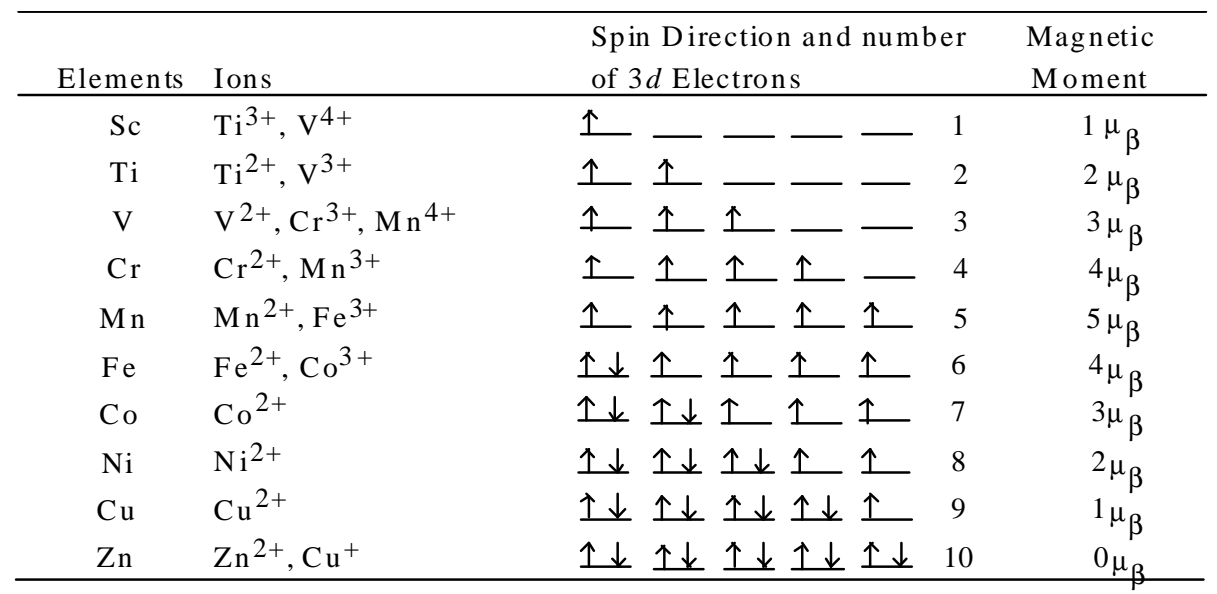

Figure. 16. The transition elements 21 through 30 , their common ions, number of $3 d$ electrons, and their magnetic moment (expressed in terms of Bohr magnetons, $\mu_{\beta}$ ). The paired electrons ( $\left.\uparrow \downarrow\right)$ have opposing spins and produce a zero net magnetic moment. Therefore, the number of unpaired electrons ( $\uparrow$ ) generally governs the magnetic properties of the ions (from Klein and Hurlbut, 1977). 

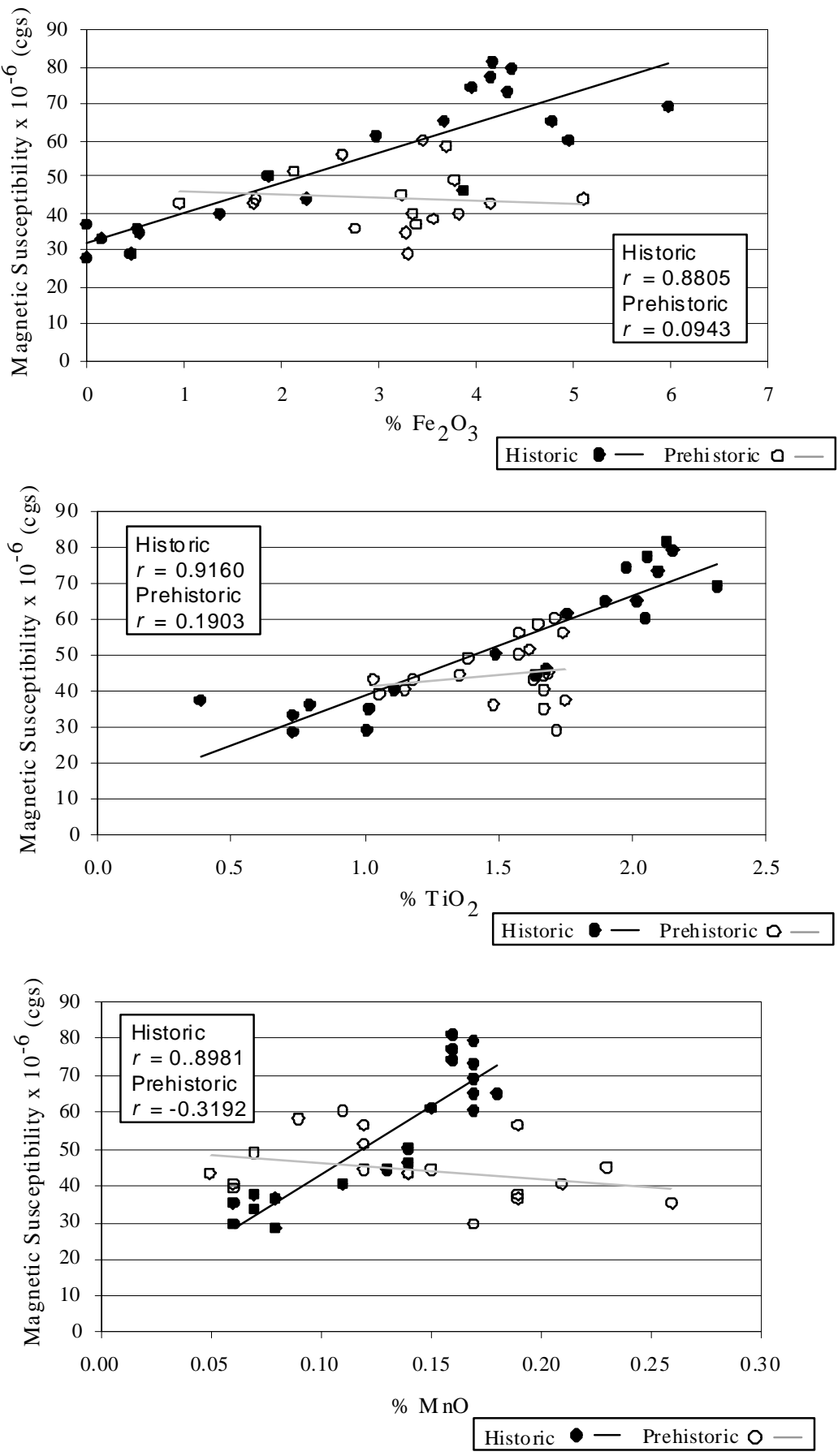

Figure 17. $\mathrm{Fe}_{2} \mathrm{O}_{3}, \mathrm{TiO}_{2}$, and $\mathrm{MnO}$ trends in historic sediment are similar to their trends in the prehistoric sediment. The $r$ values for the three oxides are positive and significant for historic sediment, whereas $r$-values indicate no relationship between magnetic susceptibility and oxide in prehistoric sediments. 


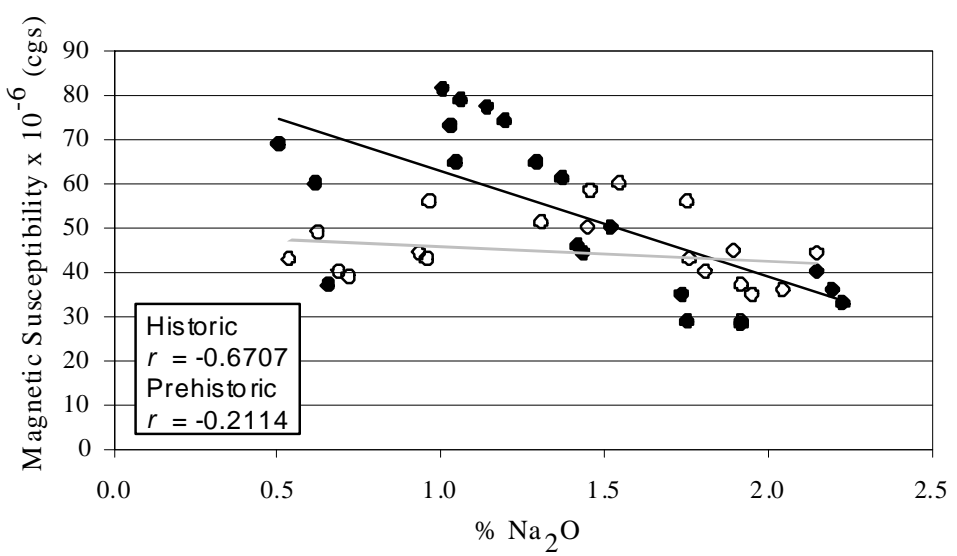

Historic $\bullet-$ Prehistoric $0-$

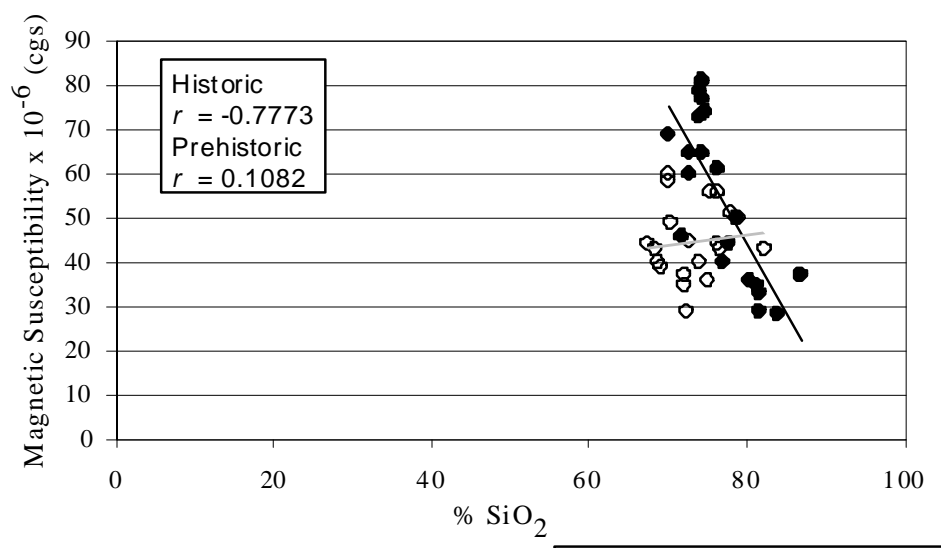

Historic - Prehis toric $0-$

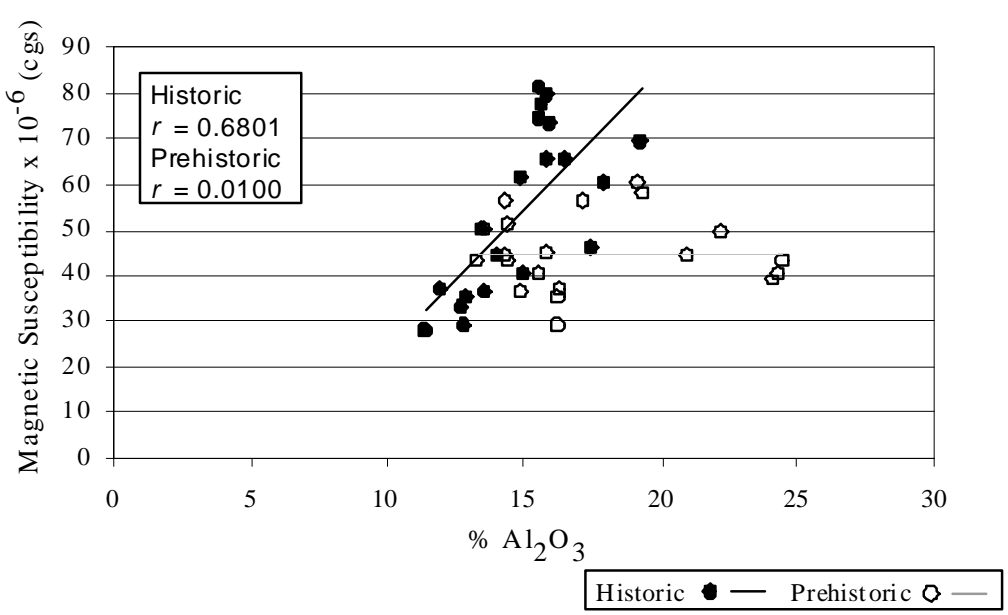

Figure 18. Trends in $\mathrm{Al}_{2} \mathrm{O}_{3}$ and magnetic susceptibility are similar to those in $\mathrm{Fe}_{2} \mathrm{O}_{3}, \mathrm{TiO}_{2}$ and $\mathrm{MnO}$. Percent $\mathrm{Na}_{2} \mathrm{O}$ has a negative correlation with magnetic susceptibility, as does $\mathrm{SiO}_{2}$. 


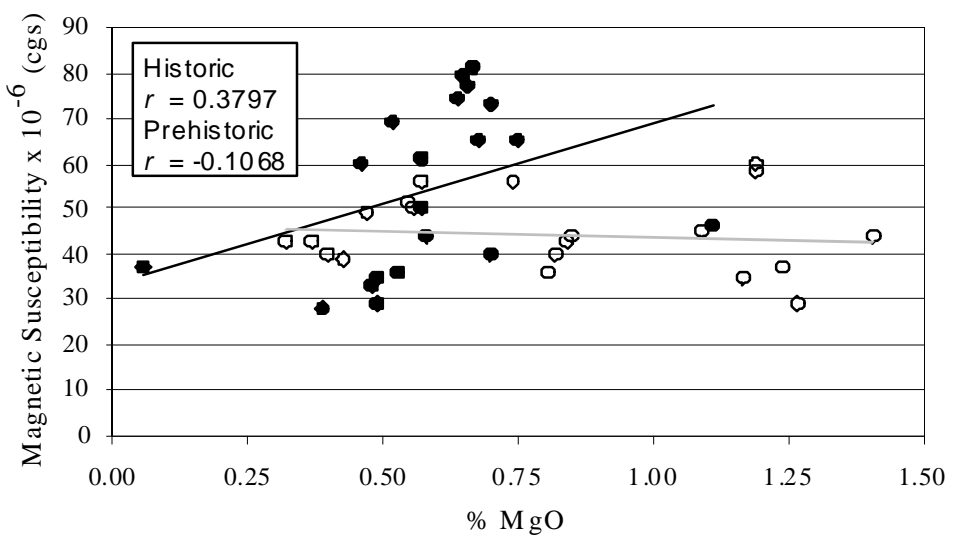

Historic - Prehistoric $0-$

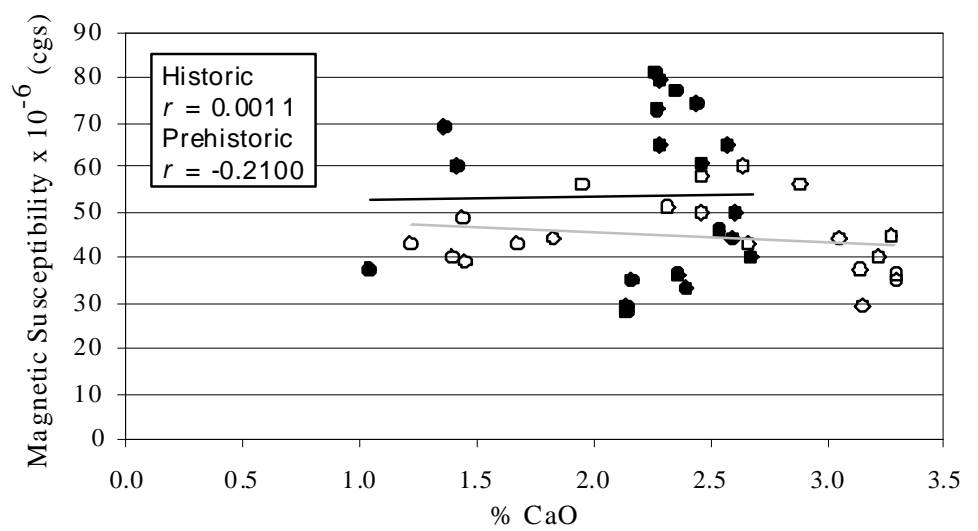

Historic $\bullet-$ Prehistoric $\bigcirc-$

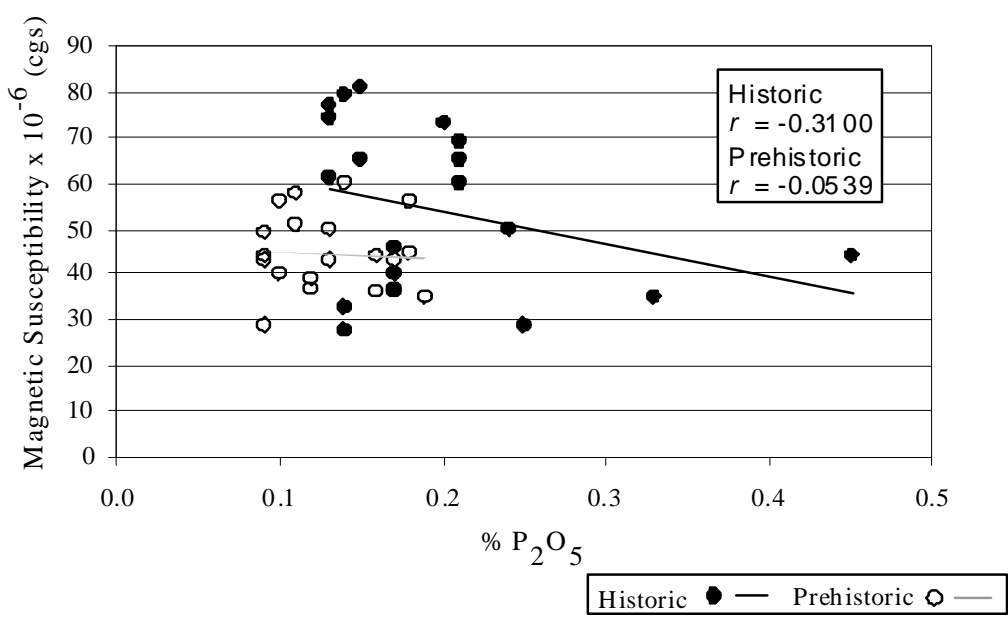

Figure 19. Plots for percent $\mathrm{MgO}, \mathrm{CaO}$, and $\mathrm{P}_{2} \mathrm{O}_{5}$ show different trends. 


\section{$X$-ray Diffraction Analyses}

X-ray diffraction analysis indicates most of the samples contain quartz, albite and epidote with minor amounts of hornblende and 14 A clays. Trace amounts of muscovite occur in only a few samples (Appendix 6).

Relationships exist between epidote, hornblende, 14 Å clays, albite, and quartz and particle-size. In historic sediments, percent epidote, hornblende, and 14 A clays increase as particle-size decreases from very fine sand to clay (Fig. 20). From very coarse sand to fine sand, there is either an inverse relationship or no relationship at all between epidote, hornblende, and $14 \AA$ clays and particle-size. The relationship between particlesize and percent epidote is less strong for prehistoric sediments, but mimics the overall shape of the curve for historic sediments. Prehistoric sediments show that coarser sediments have inverse relationships with hornblende and finer sediments have positive relationships with hornblende, except in the clay interval. The x-ray diffraction analysis preformed on the sediments was unable to indicate which specific clay mineral occurs in each sample. Typical $14 \AA$ clays are chlorite, vermiculite, and smectite. In prehistoric sediments, all $r$-values for $14 \AA$ clays and particle size, except for the fine sand interval, fall within the critical region of the 5\% significance level and are, therefore, not significant. This lack of correlation can be attributed to the abundance of $14-\AA$ clay material in the samples. Percentages of $14 \AA$ clays ranged only from 0 to 2.8 percent (Appendix VI).

Analysis of historic sediments indicate $r$-values for albite are negative from very 


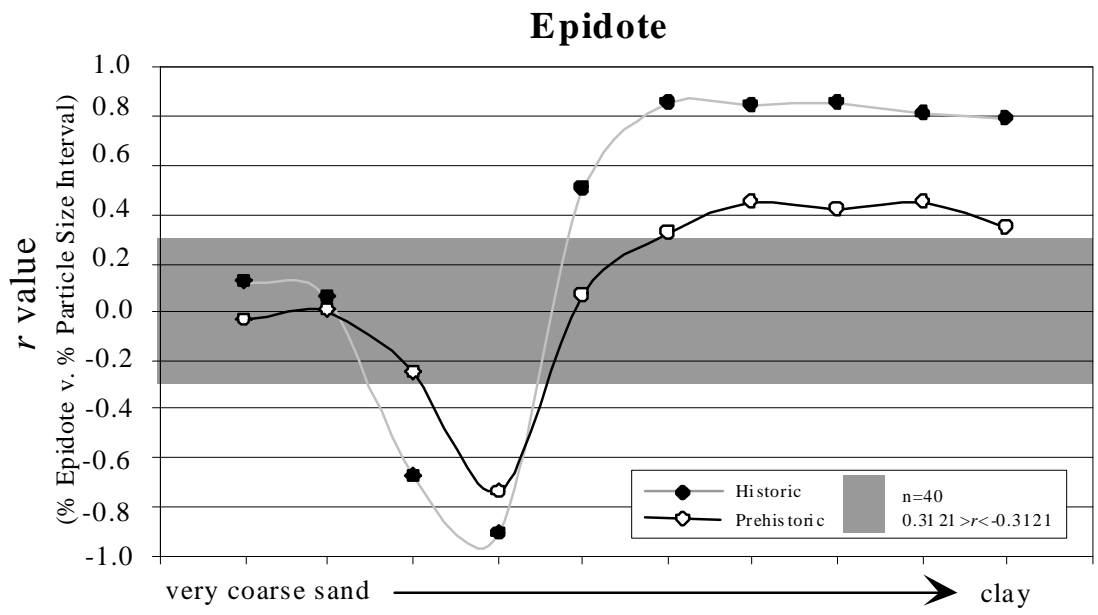

Hornblende

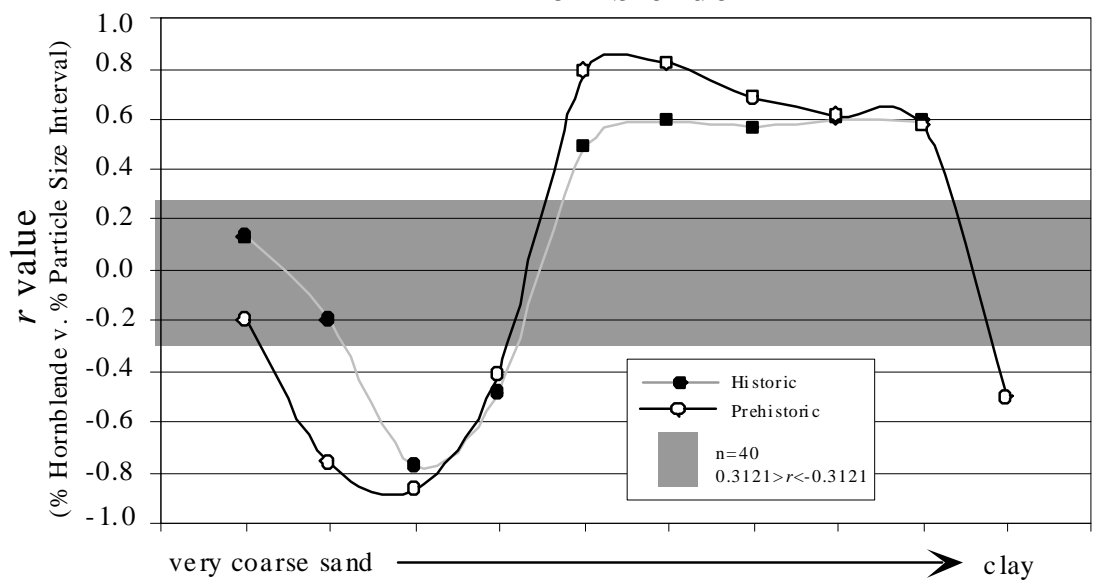

14A Clays

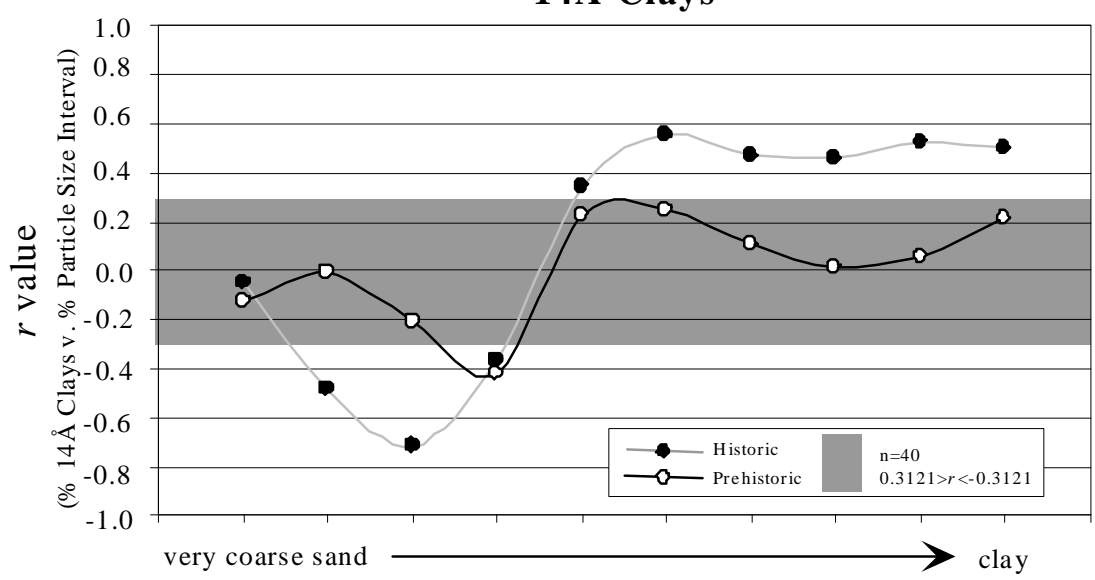

Figure 20. The $r$ values plotted in order of decreasing particle size show mineralogical differences in historic and prehistoric sediments. Trends seen in epidote, hornblende, and $14 \AA$ clays vary between historic and prehistoric sediments. 
coarse sand to very fine sand, with very fine sand having the best negative correlation (Fig. 21). Quartz is associated with very coarse sand, coarse sand, and fine sand in both historic and the prehistoric sediments (Fig. 21). However, historic and prehistoric sediments show a decrease in quartz content in samples with high percentages of very fine sand.

Trends between magnetic susceptibility and specific minerals also occur. The relationship between magnetic susceptibility and epidote and between magnetic susceptibility and hornblende are similar to trends seen previously for iron and aluminum (Figs. 17,18, \& 22). Higher percentages of epidote and hornblende correspond with higher magnetic susceptibility values in historic sediments, whereas prehistoric sediments indicate no clear relationship between magnetic susceptibility and epidote and hornblende (Fig. 22).

Historic sediments have higher percentages of clay minerals that correspond to high magnetic susceptibility values. In contrast, prehistoric sediments show no correlation between $14 \AA ̊$ clay and magnetic susceptibility (Fig. 22). A decrease in albite content with an increase in magnetic susceptibility suggests that albite acts as a dilutant for magnetic susceptibility (Fig. 23). This observation corresponds to trends in percent $\mathrm{Na}_{2} \mathrm{O}$. Magnetic susceptibility shows no trends with quartz in either historic or prehistoric sediment (Fig. 23). This lack of trend is similar to the trend observed between percent $\mathrm{SiO}_{2}$ and magnetic susceptibility. This is because of the nonmagnetic character of quartz and indicates that quartz does not enhance magnetic susceptibility. 

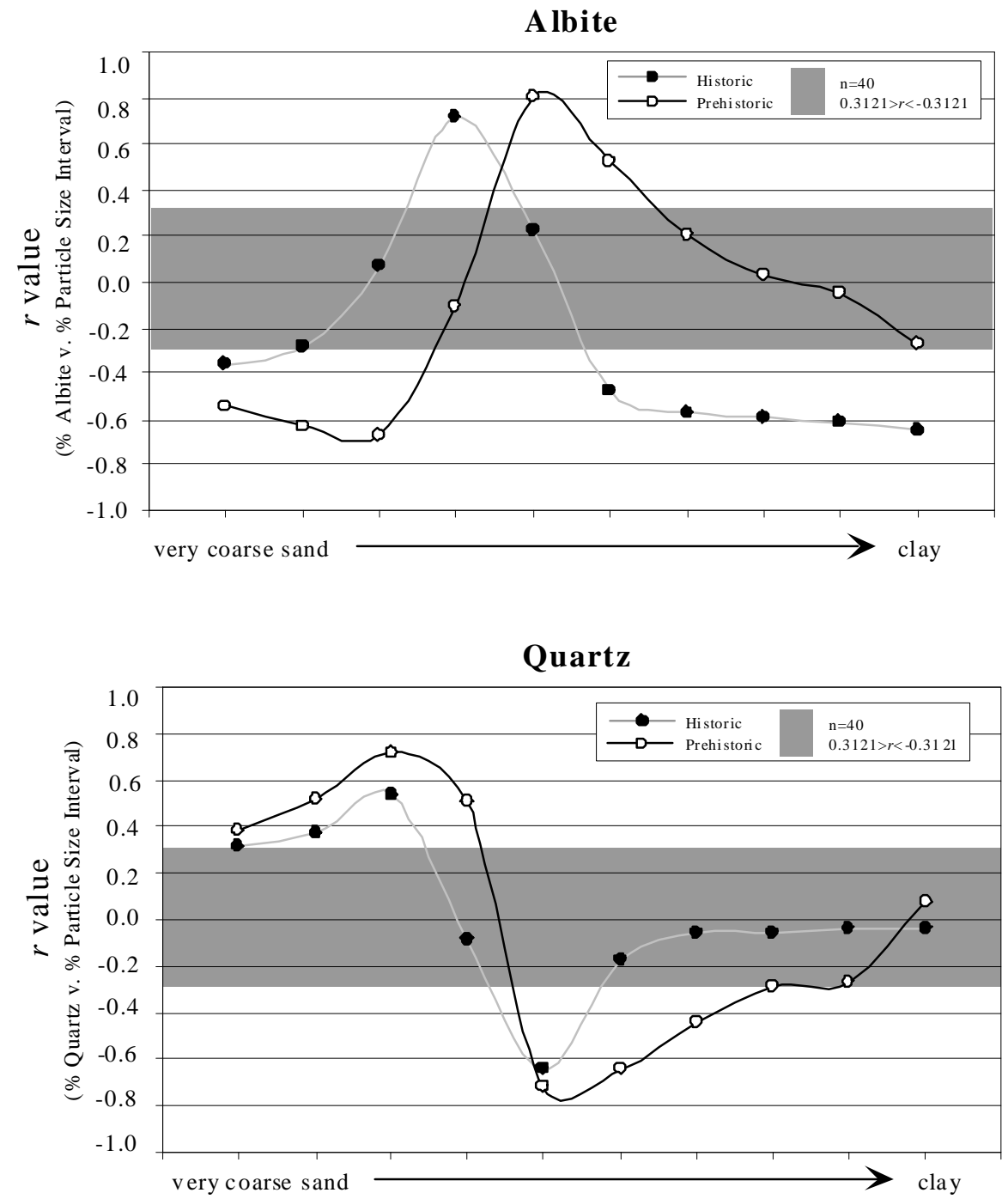

Figure 21. Plots of $r$ values showing trends in albite and quartz. Results from $\mathrm{x}$-ray diffraction analysis shows albite to be associated with fine sand in historic sediments and very fine sand in prehistoric sediments. Quartz has the best relationship with the medium sand fraction in both historic and prehistoric sediments. 


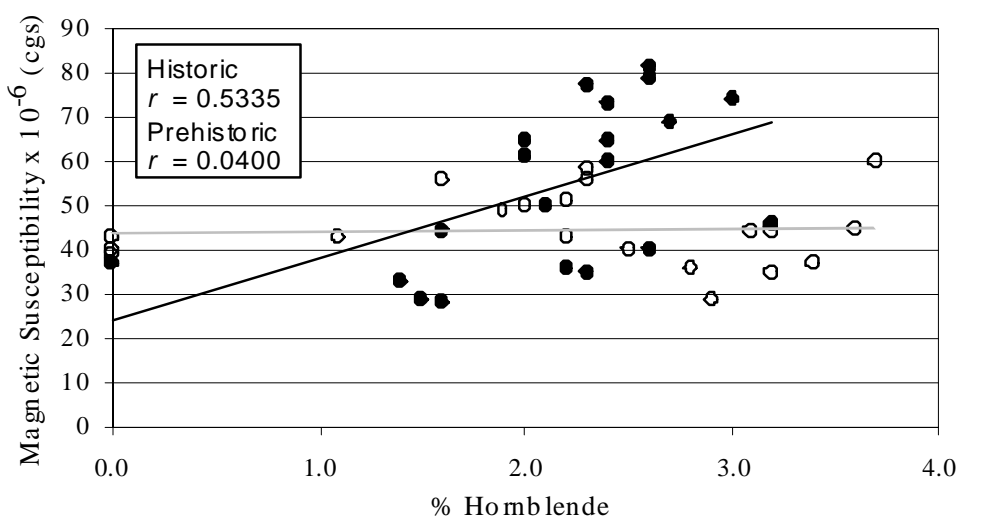

His toric - Prehistoric $0-$

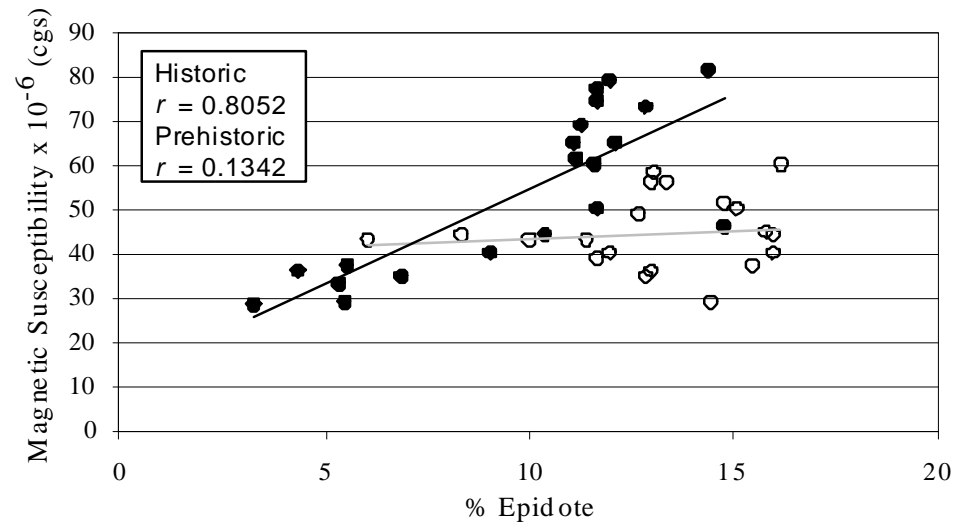

Historic - Prehis toric $0-$

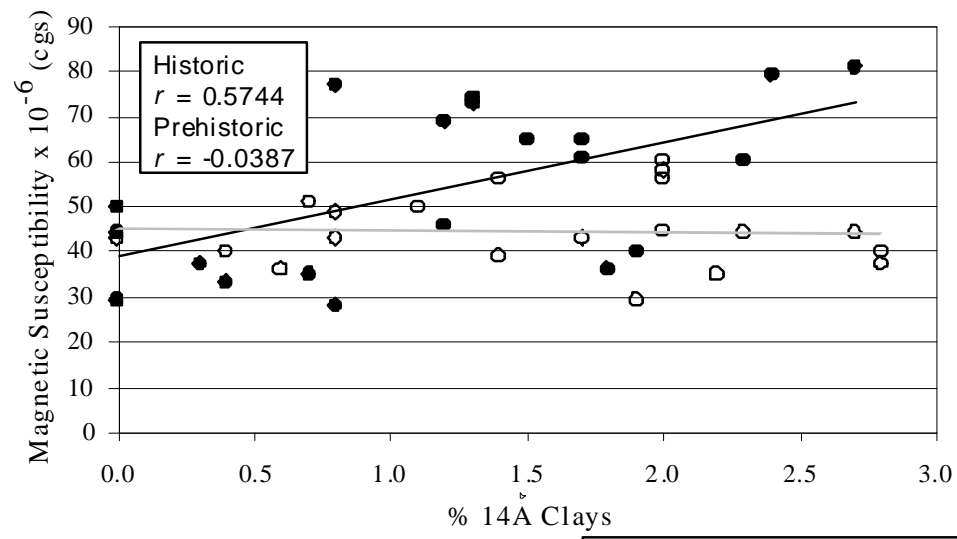

Historic $\bullet-$ Prehistoric $0-$

Figure 22. Trends in epidote and hornblende versus magnetic susceptibility are significant in historic sediments. As percent epidote increases, magnetic susceptibility increases. However, trends in epidote and magnetic susceptibility for prehistoric sediments are not significant. Trends with $14 \AA$ clays and magnetic susceptibility are not significant for either historic or prehistoric sediments. 

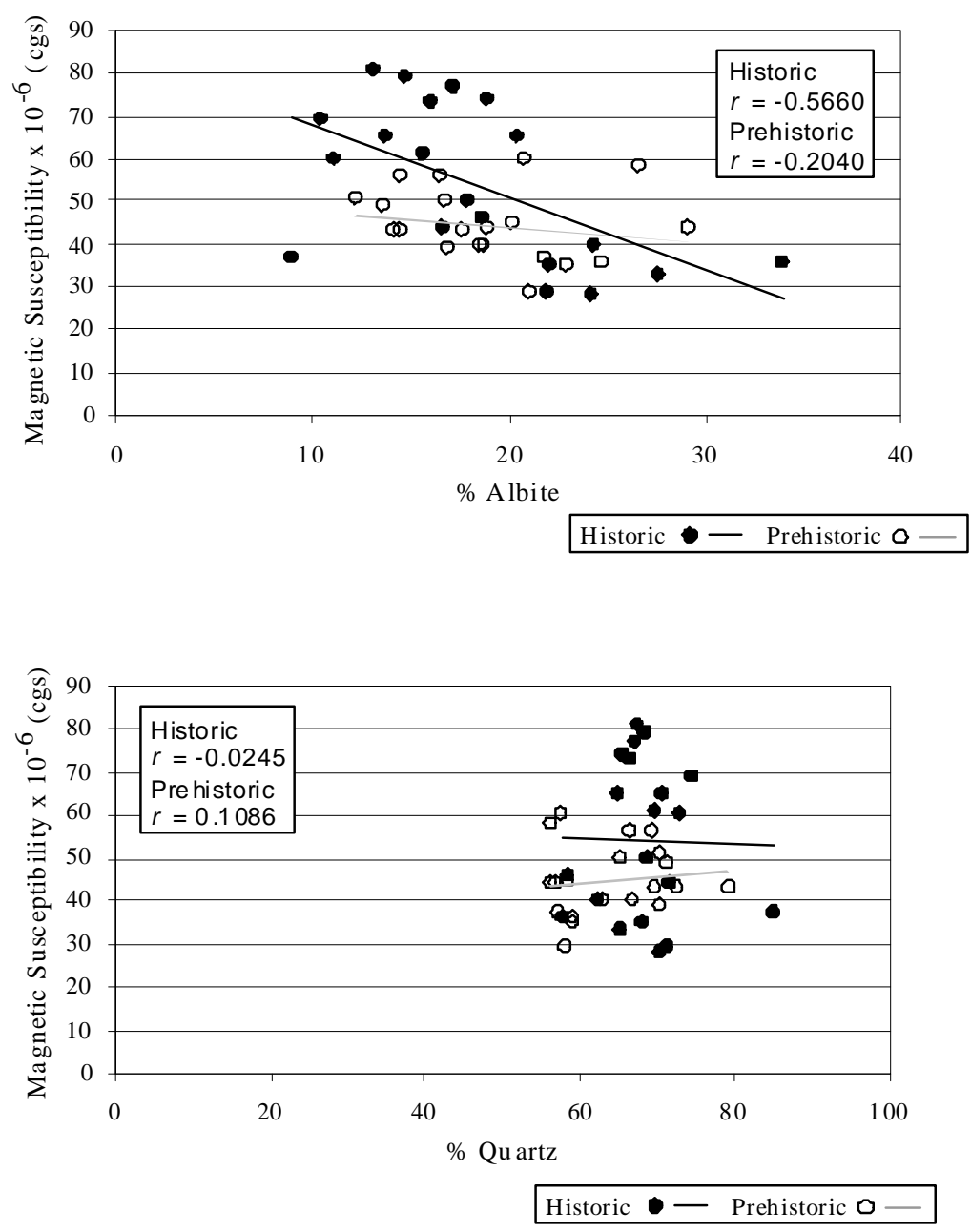

Figure 23. Plots show relationships between magnetic susceptibility and albite and quartz. 


\section{DISSCUSSION}

Bivariate plots were generated using data collected from the following analyses: particle-size, magnetic susceptibility, organic matter, elemental, and x-ray diffraction. The $r$-values from these different plots illustrate relationships between parameters. These plots show that magnetic susceptibility and mineralogy are related to particle-size.

Historic and prehistoric sediments have a distinctly different mean particle-size. The differences in the mean of the two groups could be the product of one or more processes. Increases in farming, deforestation, and runoff, since European contact, may have facilitated the erosion and transportation of larger particles into the fluvial system. Another possibility, for the change in mean particle-size, is floodplain soil development. Illuviation of fines downward into prehistoric sediments could contribute to an overall decrease in mean particle-size in the prehistoric sediments. The degree of illuviation and soil development would be controlled mainly by time and parent material, so differences may be subtle and will vary from site to site.

Although magnetic susceptibility is associated with particle-size, there are different trends in magnetic susceptibility and particle-size for historic and prehistoric sediments (Fig 10). Stronger trends, for most particle size classes, in historic sediment show that magnetic susceptibility is related more closely to particle-size in historic sediments than in prehistoric sediments. Magnetic susceptibility is generally correlated with particles finer than very fine sand in historic sediments, whereas magnetic susceptibility is more related to very coarse sand and coarse sand in prehistoric sediments. There are two factors that could contribute to these trends: sediment source and 
weathering associated with soil-profile development in uplands. Repeated plowing of soils on steep slopes exposes portions of B horizons. In mature soils, B horizons often have high magnetic susceptibility values (Gale and Hoare, 1991; Clark, 1990; Bell, 1986). Erosion of these disturbed soils, in historic times, may have introduced higher magnetic susceptibility sediments into the floodplains. Clark (1990) gives examples of a similar process in other geographic areas.

The second possibility is in situ alteration of floodplain sediments, causing mineralogical changes. These changes would be due to post-depositional weathering and soil development, which can result in the loss of magnetic susceptibility through dissolution, translocation, changes in ion states, and leaching of magnetic minerals. Movement of low magnetic susceptibility particles out of the historic sediments and downward into the prehistoric sediments would help to explain the results of Figure 10. Movement of smaller particles by soil processes, specifically translocation, will allow the accumulation of clays in prehistoric sediments. This statement implies that clay minerals would act as a dilutant to magnetic susceptibility in the prehistoric sediments. Stability of magnetic minerals will depend on the environment in which they are exposed (Gale and Hoare, 1991). Oxidization of iron may occur in situ or after dissolution when it has been transported and precipitated elsewhere (Gale and Hoare, 1991). Dissolution and leaching would depend on floodplain hydrology and geomorphology, an environment where water is actively moving through the soil profile will facilitate translocation, dissolution, or leaching of the ferrimagnetic minerals (Gale and Hoare, 1991).

Mineralogy appears to be similar in prehistoric and historic sediments. However, different minerals are associated with different particle-size classes in the two age groups. 
Relationships between mineralogy and particle size are indicated by $r$-values, determined from plots of oxide or element content versus percent particle-size interval. Figures 24 and 25 show $r$ plots for x-ray diffraction and x-ray fluorescence as related to particle-size for historic and prehistoric sediments. Phosphate was omitted due to likely effects of fertilizers.

Sediments from very coarse sand to very fine sand have different trends than trends in finer sediments, for both historic and prehistoric sediments. Significant trends for historic sediments in the fine sand to very fine sand interval have a positive correlation with $\mathrm{Fe}_{2} \mathrm{O}_{3}, \mathrm{Al}_{2} \mathrm{O}_{3}, \mathrm{TiO}_{2}, \mathrm{MnO}, \mathrm{MgO}$, epidote, 14 A clays and hornblende and have a negative correlation with $\mathrm{SiO}_{2}, \mathrm{Na}_{2} \mathrm{O}$, and quartz. The main differences in trends for mineralogy within this particle size interval are a negative correlation with $\mathrm{Fe}_{2} \mathrm{O}_{3}$ and $\mathrm{Al}_{2} \mathrm{O}_{3}$ in historic sediments instead of a positive correlation for prehistoric sediments.

From fine sand to clay, there are distinct trends in both historic and prehistoric sediments. The mineralogy of historic sediments is consistent; from the fine sand to the clay interval, epidote, $14 \AA$ clays, hornblende, $\mathrm{Fe}_{2} \mathrm{O}_{3}, \mathrm{Al}_{2} \mathrm{O}_{3}, \mathrm{TiO}_{2}, \mathrm{MnO}$, and $\mathrm{MgO}$ are present and are positively correlated. Silica $\left(\mathrm{SiO}_{2}\right), \mathrm{Na}_{2} \mathrm{O}$, and quartz are also present in the same interval but show a negative correlation and, therefore, imply a decrease in abundance. In prehistoric sediments, only $\mathrm{Fe}_{2} \mathrm{O}_{3}$ and $\mathrm{Al}_{2} \mathrm{O}_{3}$ have positive relationships with the clay interval; the other oxides and minerals are negatively correlated to the clay interval. When trends in mineralogy for historic sediments are compared to magnetic susceptibility, it is apparent that trends in $\mathrm{Fe}_{2} \mathrm{O}_{3}, \mathrm{Al}_{2} \mathrm{O}_{3}, \mathrm{TiO}_{2}, \mathrm{MnO}, \mathrm{MgO}$, epidote, $14 \AA$ clays and hornblende are similar to those seen in magnetic susceptibility (Figs. 24 and 25) 

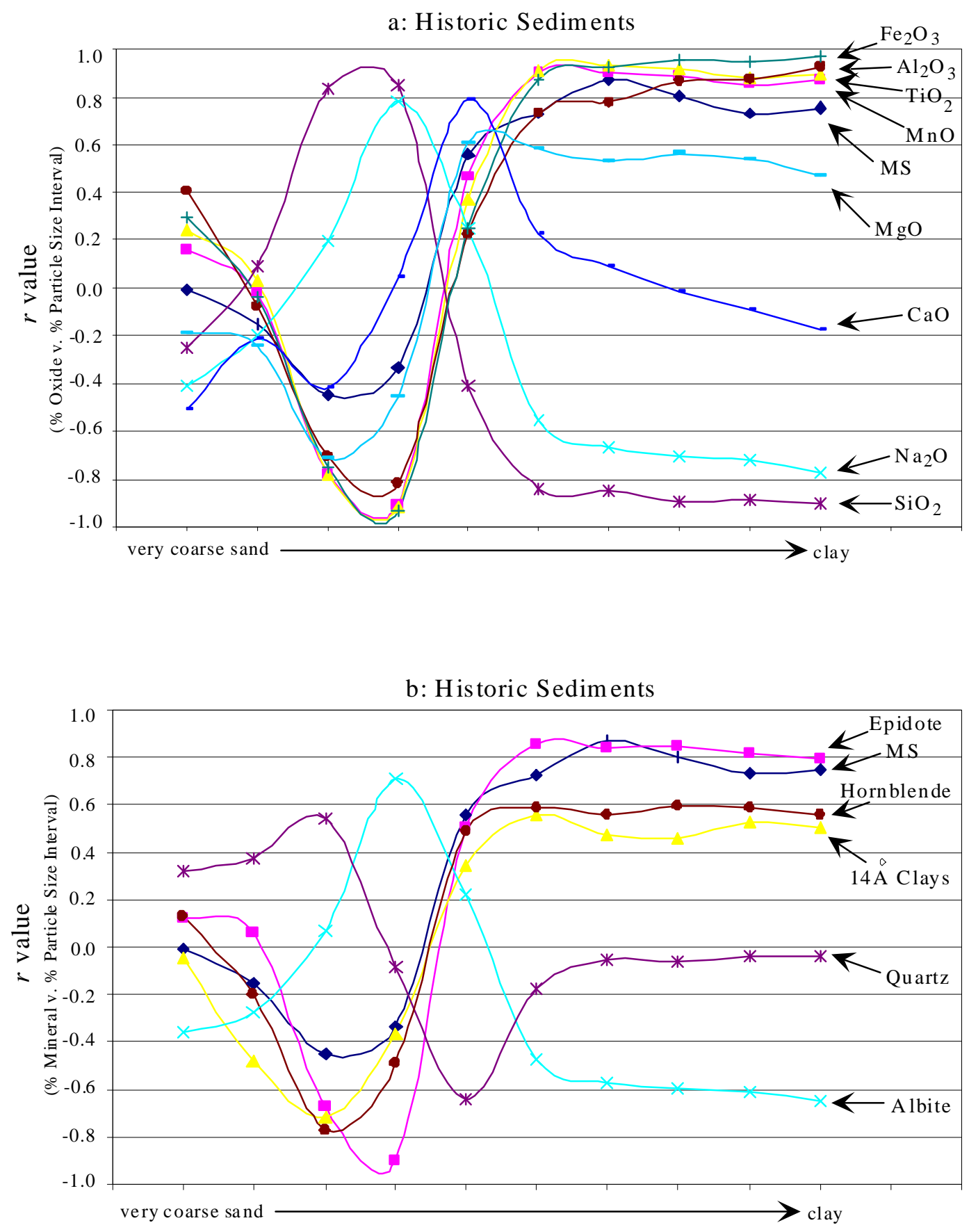

Figure 24. Plot showing oxides and minerals when compared to particle size for historic sediments. Note the character of the magnetic susceptibility (MS) curve. 


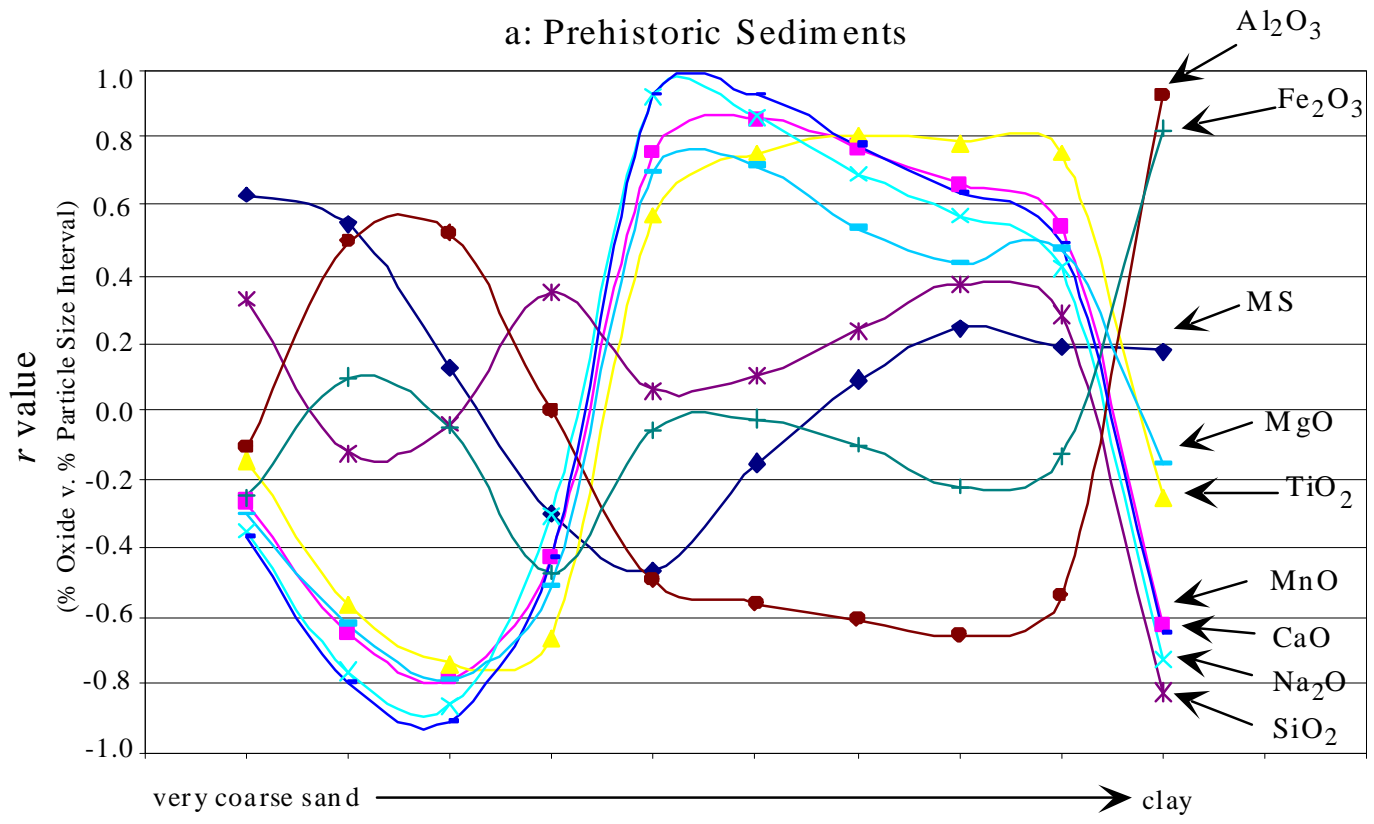

b: Prehistoric Sediments

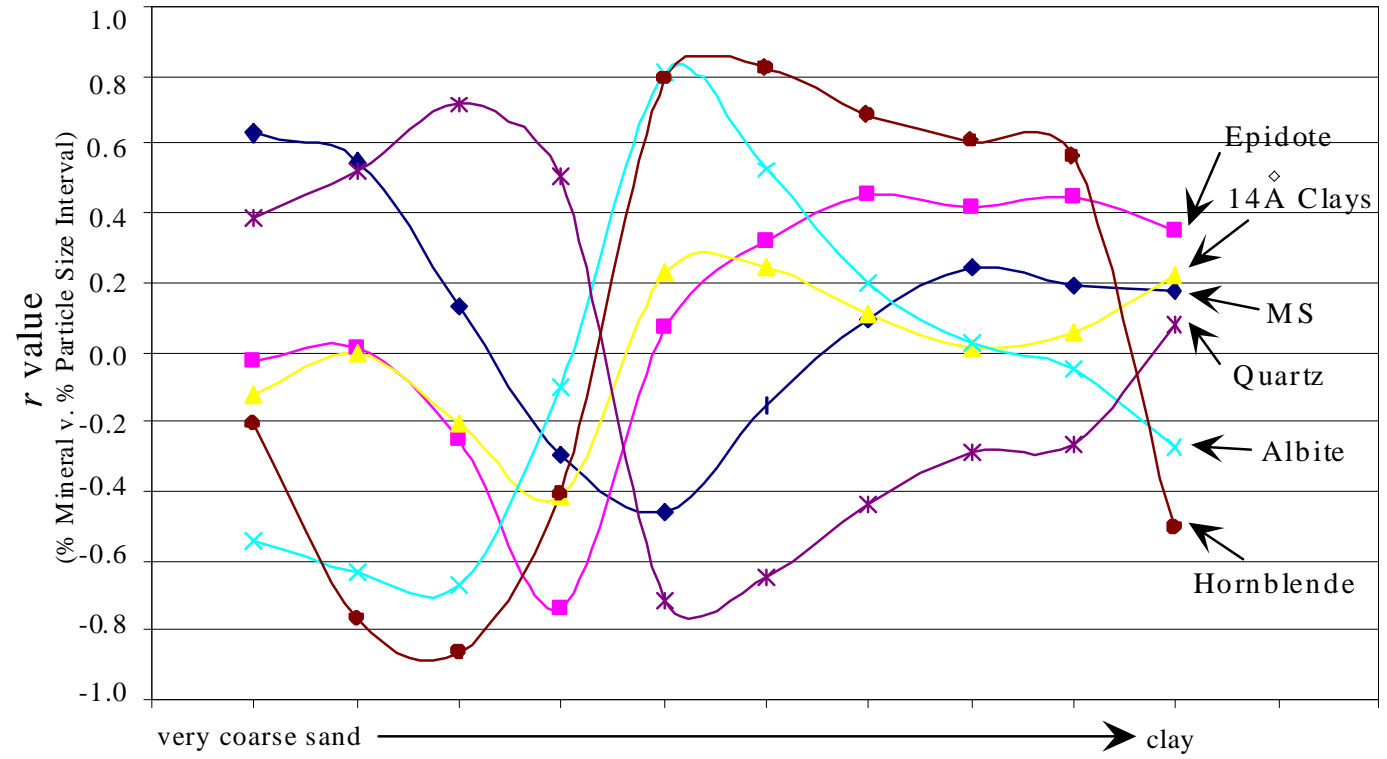

Figure 25. Plot showing all oxides and minerals when compared to particle size for prehistoric sediments. Trends here are less distinct than those seen in historic sediments. 
For prehistoric sediments there is not a direct relationship between magnetic susceptibility and mineralogy.

Algae and bacteria produce magnetite as a by-product, causing increases in magnetic susceptibility (Stein, 1992). For this reason, percent organic matter in the bulk sample was analyzed. Analysis shows organic matter is slightly higher in historic sediments and is positively related to particle-size. Organic matter generally increases as particle-size decreases. With higher percent organic matter in the prehistoric sediments, it would be intuitive that magnetic susceptibility would be higher for those sediments. However, percent organic matter does not directly increase with increasing magnetic susceptibility in historic sediment or prehistoric sediments. Organic matter trends in historic and prehistoric sediments may be explained through particle-size and soil development.

\section{CONCLUSIONS}

Differentiation of historic and prehistoric sediments in fluvial systems in the Piedmont physiographic province can be accomplished using a combination of particle size, magnetic susceptibility, and elemental analysis. When the sediment samples are divided into historic and prehistoric ages based on position relative to the paleosol, certain trends occur in particle size, organic matter, and mineralogy. Historic sediments tend to be slightly coarser and less well sorted than prehistoric sediments (finer and better-sorted) (Fig. 7). Analyses indicate that percent organic matter is somewhat related to mean particle-size, but is not significantly related to magnetic susceptibility. Organic content increases as mean particle-size decreases in both historic and prehistoric 
sediments (Fig. 11). Particle size and organic matter analysis show subtle sedimentological differences between the historic and prehistoric populations, but more distinct mineralogical differences exist. X-ray diffraction analysis can be used to document these differences, but elemental analysis produces similar results and is less expensive.

Distinct trends appear in both historic and prehistoric sediments when percent oxide, percent mineral, or magnetic susceptibility is compared to particle-size (Fig. 24 \& 25). Using particle size as a link between magnetic susceptibility and mineralogy, a conclusion can be made to the role mineralogy plays in magnetic susceptibility of sediments. Figures 24 and 25 illustrate those particle size intervals with high magnetic susceptibility values; values that correspond to minerals and oxides with high $r$-values. There are distinct differences between relationships in historic and prehistoric populations.

Positive relationships exist between epidote, hornblende, and $14 \AA$ clays and particle-size in the historic sediments. The minerals and oxides that correspond to high magnetic susceptibility in the historic sediments are those that have better relationships with Fe, Mn, Ti, Mg, and $\mathrm{Al}$ (Fig. 24a). Because $\mathrm{Fe}^{+3}$ and $\mathrm{Mn}^{+2}$ are the most magnetic susceptible of the five oxides it would be expected that their $r$-values correspond to higher magnetic susceptibility values. Titanium $\left(\mathrm{Ti}^{+2}\right)$ has two unpaired electrons, making it less magnetic than iron and manganese, but still significant (Fig. 16). The following are diamagnetic ions: $\mathrm{Na}^{+1}, \mathrm{Si}^{+2}, \mathrm{Mg}^{+2}$ and $\mathrm{Al}^{+3}$. Diamagnetic ions have a net magnetic moment is zero and they are not attracted to a magnet (Klein \& Hurlbut, 1999). Magnesium and aluminum would be expected to be associated with low magnetic 
susceptibility values because they are diamagnetic ions, however, in historic sediments they are associated with high magnetic susceptibility values. The fact that these elements have similar trends to highly magnetic susceptible sediments may be because of their association with high magnetic susceptibility minerals containing iron and manganese. This relationship can be seen in the x-ray diffraction data. Figure $24 \mathrm{~b}$ shows trends for epidote, hornblende, and $14 \AA$ clays to be similar to more susceptible sediments. The chemical equations for these three minerals are as follows:

Epidote: $\mathrm{Ca}_{2}(\mathrm{Al}, \mathrm{Fe}) \mathrm{Al}_{2} \mathrm{O}\left(\mathrm{SiO}_{4}\right)\left(\mathrm{Si}_{2} \mathrm{O}_{7}\right)(\mathrm{OH}) 3$ Hornblende: $(\mathrm{Ca}, \mathrm{Na})_{2-3}(\mathrm{Mg}, \mathrm{Fe}, \mathrm{Al})_{5} \mathrm{Si}_{6}(\mathrm{Si}, \mathrm{Al})_{2} \mathrm{O}_{22}(\mathrm{OH})_{2}$ 14 A Clays (Chlorite): $(\mathrm{Mg}, \mathrm{Fe})_{3}(\mathrm{Si}, \mathrm{Al})_{4} \mathrm{O}_{10}(\mathrm{OH})_{2} \cdot(\mathrm{Mg}, \mathrm{Fe})_{3}(\mathrm{OH})_{6}$ (from Klein and Hurlbut, 1977)

As can be seen, magnesium and aluminum can be associated with iron in hornblende and in $14 \AA$ clays. Aluminum is also associated with epidote. These relationships help to explain associations seen between high magnetic susceptibility and $\mathrm{Al}_{2} \mathrm{O}_{3}$ and $\mathrm{MnO}$. The association of an oxide with magnetic susceptibility is linked to overall mineralogy of the sediments. Varying percentages of magnetic minerals and nonmagnetic minerals will affect the overall magnetic susceptibility of a sample and may be the controlling factor for magnetic susceptibility values in prehistoric sediments.

Sodium, silica and, to some degree, calcium, have opposite trends from the other oxides in historic sediments. Although sodium is associated with epidote and hornblende, it is more likely that most of the sodium is associated with feldspars. This association is apparent when analyzing the $r$ curves for sodium and albite in Figure 24b. The curves show that sodium is associated with low magnetic susceptibility values and, more specifically, lower magnetic susceptibility albite $\left(\mathrm{NaAlSi}_{3} \mathrm{O}_{8}\right)$. The fact that 
calcium is not directly associated with high or low magnetic susceptibility may be due to calcium's association with high magnetic susceptibility epidote and hornblende, as well as, low magnetic susceptibility albite. Albite $\left(\mathrm{NaAlSi}_{3} \mathrm{O}_{8}\right)$ and anorthite $\left(\mathrm{CaAlSi}_{3} \mathrm{O}_{8}\right)$ in x-ray diffraction can have very similar diffraction patterns. Samples probably contain mostly albite with varying amounts of $\mathrm{Ca}$ substitution in them. Silica $\left(\mathrm{SiO}_{2}\right)$ and quartz are associated with low magnetic susceptibility values as would be expected.

The trends in prehistoric sediments are distinctly different than those in historic sediments described above. Overall, high magnetic susceptibility in prehistoric sediments does not seem related to typical high magnetic susceptibility ions. High magnetic susceptibility ions and minerals with positive $r$-values in the fine sand to fine silt interval for the prehistoric sediments are $\mathrm{MgO}, \mathrm{TiO}_{2}, \mathrm{MnO}, \mathrm{CaO}, \mathrm{Na}_{2} \mathrm{O}$, and hornblende (Fig. 25). In the same interval, $\mathrm{Fe}_{2} \mathrm{O}_{3}$ and $\mathrm{Al}_{2} \mathrm{O}_{3}$ have negative $r$-values. This trend is opposite the trends in historic sediments of the same particle size interval. As previously discussed, $\mathrm{Fe}_{2} \mathrm{O}_{3}$ and $\mathrm{Al}_{2} \mathrm{O}_{3}$ tends to be associated with high magnetic susceptibility epidote, hornblende, and $14 \AA$ clays in historic sediments. The trends in mineralogy and oxides in prehistoric sediments may imply that either certain minerals and oxides may not be abundant, or there maybe an excess of non-magnetic minerals. Only $\mathrm{Fe}_{2} \mathrm{O}_{3}, \mathrm{Al}_{2} \mathrm{O}_{3}$, epidote, and $14 \AA$ clays have positive $r$-values in the clay fraction. However, magnetic susceptibility is not obviously related to particle size and, therefore, it is not related to mineralogy.

There are several keys to differentiation of historic and prehistoric sediments. The keys are associated with changes in magnetic susceptibility and mineralogy with particle size. One of the main differences occurs in the transition from silt to clay interval. 
Magnetic susceptibility is higher in finer fraction ( $<3$ to $<8$ phi) within historic deposits than in prehistoric deposits. Differences occur in the relationship between magnetic susceptibility and mineralogy at the transition from silt to clay. Relative amounts of $\mathrm{TiO}_{2}, \mathrm{CaO}, \mathrm{MgO}$, and $\mathrm{MnO}$ are high in the silt interval ( $<4$ to 8 phi) for prehistoric sediments and amounts of $\mathrm{Fe}_{2} \mathrm{O}_{3}$ and $\mathrm{Al}_{2} \mathrm{O}_{3}$ increase dramatically from the silt to the clay interval $\left(<8\right.$ phi). In prehistoric sediments, $\mathrm{SiO}_{2}, \mathrm{Na}_{2} \mathrm{O}$, and $\mathrm{CaO}$ decrease dramatically in the clay interval ( $<8$ phi) relative to the silt interval ( $<4$ to 8 phi). In historic sediments, the relative amounts of $\mathrm{TiO}_{2}, \mathrm{Al}_{2} \mathrm{O}_{3}, \mathrm{Fe}_{2} \mathrm{O}_{3}$, and $\mathrm{MnO}$ are high in finer sediments $(<3$ to $<8$ phi) and are associated with high magnetic susceptibility.

Further analysis can and should be done concerning the strength of the relationships between particle-size and mineralogy. The differences discussed above may become more clear after further analysis. Characterization may be achieved through mineralogical analysis of individual particle size splits. Other areas that need to be examined more closely are the relationships between soil taxonomy and mineralogy. The use of soil taxonomy may be helpful in identifying associations between pedology, mineralogy, and magnetic susceptibility. Certain mineralogies may be found to be indicative of specific soil properties and used to quickly identify sediments. 


\section{REFERENCES CITED}

Bell, Alison M., 1986, Morphology and stratigraphy of terraces in the upper Shenandoah Valley, Virginia (MS thesis): Morgantown, West Virginia University, 161 p.

Bettis, E. A. and Benn, D. W., 1984, An archaeological and geomorphological survey in the central Des Moines River valley, Iowa: Plains Anthropologist, v. 29, p. 211-227.

Bison Instruments, 1970, Bison magnetic susceptibility system 3101: Instruction Manual; Bison Instruments, St. Louis, Missouri, 10 p.

Clark, A., 1990, Seeing Beneath the Soil: Prospecting methods in archaeology: B. T. Batsford Ltd., London, p. 99-168.

Costa, J. E., 1975, Effects of agriculture on erosion and sedimentation in the Piedmont Province, Maryland: Geological Society of America Bulletin, v. 86, p. 1281-1286.

Davis, J.C., 1973, Statistics and data analysis in Geology: Second Edition: John Wiley and Sons, New York, 646 p.

Earth Science Information Office (ESIO), 1993, 1:100,000-Scale Digital Line Graph (DLG) Data Hydrography and Transportation: U.S. Department of the Interior, U.S. Geological Survey, Earth Science Information Office (ESIO), Reston, Virginia.

Fanning, D. S. and Fanning, M. C. B., 1986, Soil Morphology, Genesis, and Classification: John Wiley and Sons, Inc., New York, 395 p.

Ferring, R. C., 1986, Rates of fluvial sedimentation: Implications for archaeological variability: Geoarchaeology: An International Journal, v. 1(3), p. 259-274.

Ferring, R. C., 1992, Alluvial Pedology and Geoarchaeological Research: in Soils in Archaeology, Holliday, V. T., Editor: Smithsonian Institute Press, Washington District of Columbia, p. 1-39.

Folk, R.L., 1980, Petrology of sedimentary rocks: Hemphill's, Austin, Texas, 184 p.

Gale, S. J. and Hoare, P. G., 1991, Quaternary Sediments: Petrographic methods for the study of unlithified rocks: Belhaven and Halsted Press, New York, p. 201-229.

Gerrard, A. J., 1987, Alluvial Soils: Van Nostrand Reinhold Company, New York, 160 p.

Gladfelter, B., 1985, On the interpretation of archaeological sites in alluvial settings: in, Archaeological sediments in context, J.K. Stein and W. R. Farrand Editors: Center for the Study of Early Man: Institute for Quaternary Studies, Orono, Maine, p. 41-52. 
Gottschalk, L. C. and Jones, V. H., 1955, Valleys and Hills erosion and sedimentation, in Water: U.S. Department of Agriculture Yearbook of Agriculture, p. 135-143.

Hall, G. F., 1983, Pedology and Geomorphology: in Pedogenesis and Soil Taxonomy I. Concepts and Interactions, Wilding, L. P., Smeck, N.E., and Hall, G. F. Editors, Elsevier Science Publications, Amsterdam, p. 117-140.

Happ, S. C, 1940, Some principles of accelerated stream and valley sedimentation, Technical Bulletin No. 695: U. S. Department of Agriculture, Washington, District of Columbia, p. 1- 123.

Hess, H. H., 1956, Notes on operation of Frantz Isodynamic Magnetic Separator: Instrument Instruction Booklet of Frantz, S. G. Company, Inc., New Jersey, 6 p.

Holliday, V. T., 1992, Soil Formation, Time, and Archaeology: in Soils in Archaeology, Holliday, V. T., Editor, Smithsonian Institute Press, Washington, District of Columbia, p. 101-117.

Jacobson, R. B. and Coleman, D. J., 1986, Stratigraphy and recent evolution of Maryland piedmont flood plains: American Journal of Science, v. 286, p. 617-637.

Johnson, Gerald G. and Smith, Deane K., 1991, X-ray powder package analysis: The Penn State University, Pittsburgh, Pennsylvania, 40 p.

Klein, C. and Hurlbut, C.S., 1999, Manual of Mineralogy: John Wiley and Sons, New York, p. 170-180, p. 272-274.

Jenny, 1941, Factors of soil formation: McGraw-Hill Book Company, Inc., New York, $281 \mathrm{p}$.

Knox, J. C., 1977, Human impacts on Wisconsin stream channels: Annals of the Association of American Geographers, v. 67(3), p. 323-342.

Knox, J. C., 1987, Historical valley floor sedimentation in the upper Mississippi Valley: Annals of the Association of American Geographers, v. 77(2), p. 224-244.

Larson C. E. and Schuldenrien, J., 1990, Depositional history of an archaeologically dated flood plain, Haw River, North Carolina: Geological Society of America, Centennial Special Volume 4, p. 161-181.

Lautzenheiser, L., Eastman, J. M., Seramur, K., and Holm, M. A., 1997, Archaeological survey proposed Randleman reservoir Randolph and Gilford Counties, North Carolina: Vol. 1 Technical Report: Coastal Carolina Research, Inc., Tarboro, North Carolina, 138 p. 
Lindsley, D. H., 1989, Oxide Minerals: Reviews in mineralogy: Rumble, Douglas, Editor: Mineralogical Society of America, District of Columbia, v. 3, p. 1-60.

Magilligan, F. J., 1985, Historical floodplain sedimentation in the Galena River basin, Wisconsin and Illinois: Annals of the Association of American Geographers, v. 75(4), p. 583-594.

Reid, W. H., Lautzenheiser, L., and Seramur, K., 1998, Archaeological testing proposed Randleman reservoir Randolph and Gilford Counties, North Carolina: Vol. 2 The prehistoric sites: Coastal Carolina Research, Inc., Tarboro, North Carolina, 192 p.

SediGraph 5100, 1989, SediGraph 5100: Instruction Manual: Norcross, Georgia, 355 p.

Soil Survey Staff, 1987, Keys to Soil Taxonomy; Soil Management Support Services Technical Monograph No. 6, Third Printing: Department of Agronomy, Cornell University, Ithaca, New York, 644 p.

Stein, J. K., 1992, Organic matter in soils: in Soils in Archaeology, Holliday, V. T., Editor: Smithsonian Institute Press, Washington and London, p. 193-216.

Stafford, T., 1981, Alluvial Geology and Archaeological Potential of the Texas Southern High Plains: American Antiquity, v. 46(3), p. 548-565.

Tite, M. S. and Mullins, C., 1971, Enhancement of the magnetic susceptibility of soils on archaeology sites: Archaeometry, v. 13(2), p. 209-219.

Tite, M. S., 1972, The influence of geology on the magnetic susceptibility of soils on archaeological sites: Archaeometry, v. 14(2), p. 229-236.

Trimble, S. W., 1975, Denudation Studies: Can we assume a steady state?: Science, v. 188 , p. $1207-1208$.

Trimble, S. W., 1983, A sediment budget for Coon Creek basin in the driftless area, Wisconsin, 1853-1977: American Journal of Science, v. 283, p. 454-474.

U. S. Geological Survey (USGS), 1997, United States Surface-Water Data Retrieval URL: http://water.usgs.gov/swr/ 
APPENDIX I

Soil Profiles 
Key to Soil Profiles

$\begin{aligned} & \text { Texture } \\ & \mathrm{S}=\text { sandy } \\ & \mathrm{SL}=\text { sandy loam } \\ & \mathrm{LS}=\text { loamy sand } \\ & \mathrm{StL}=\text { silty loam } \\ & \mathrm{StS}=\text { silty sand } \\ & \mathrm{MS}=\text { medium sand }\end{aligned}$

Structure

$\begin{aligned} \mathrm{G} & =\text { granular } \\ \mathrm{F} & =\text { firm } \\ \mathrm{P} & =\text { Platy } \\ \mathrm{SBL} & =\text { subangular blocky } \\ \mathrm{CSBL} & =\text { coarse subangular blocky } \\ \mathrm{MSBL} & =\text { medium subangular blocky } \\ \mathrm{FSBL} & =\text { fine subangular blocky } \\ & \text { Moist Consistence } \\ \mathrm{L} & =\text { loose } \\ \mathrm{Fri} & =\text { friable } \\ \mathrm{Vfri} & =\text { very friable } \\ \mathrm{F} & =\text { firm }\end{aligned}$

Boundary

$\begin{aligned} \mathrm{AW} & =\text { abrupt wavy } \\ \mathrm{AS} & =\text { abrupt smooth } \\ \mathrm{CW} & =\text { clear wavy } \\ \mathrm{CS} & =\text { clear smooth } \\ \mathrm{GW} & =\text { gradual wavy } \\ \mathrm{GI} & =\text { gradual irregular } \\ \mathrm{DW} & =\text { diffuse wavy } \\ \mathrm{DI} & =\text { diffuse irregular }\end{aligned}$

Several of the following soil profiles were taken from identified archaeology sites.

They are identified by state (i.e. 31), county (i.e. RD), and a state assigned number (i.e. 1164). 


\begin{tabular}{|c|c|c|c|c|c|c|c|c|c|c|c|}
\hline \multicolumn{12}{|c|}{ (20)(Jinutio) } \\
\hline Horizon & Depth & Mottling & Moist & Texture & Structure & $\begin{array}{c}\text { Moist } \\
\text { Consistence }\end{array}$ & Reaction & Boundary & Roots & $\begin{array}{c}\text { Coarse } \\
\text { Fragments }\end{array}$ & Clay Skins \\
\hline $\mathrm{Ap}$ & $0-26$ & & $7.5 Y R 4 / 4$ & $\overline{L S}$ & $\mathrm{SBL}$ & V. Fri & 5.5 to 5.0 & AW & fine many & & \\
\hline $\mathrm{BA}$ & $26-56$ & & 10YR5/4 & $\overline{L S}$ & $\mathrm{SBL}$ & Fri & 5.5 & $\mathrm{CW}$ & fine few & & \\
\hline $\mathrm{B}$ & $56-86$ & fine many $5 \mathrm{YR} 3 / 3$ & 10YR5/6 & $\overline{S L}$ & $\overline{S B L}$ & Fri & 6.5 & CS & fine few & few fine pebbles & thin \\
\hline $\mathrm{B}$ & $86-91$ & & $7.5 Y R 4 / 6$ & $\begin{array}{c}\text { Gravelly } \\
\text { sand }\end{array}$ & $\overline{\mathrm{SBL}}$ & Fri & 7.0 & CS & fine few & & \\
\hline $\bar{B}$ & $91->115$ & $\begin{array}{c}\text { fine many } 5 Y R 3 / 3 \text { coarse } \\
\text { few } 10 Y R 6 / 6\end{array}$ & $7.5 Y R 4 / 6$ & $\overline{\mathrm{SL}}$ & $\overline{\mathrm{SBL}}$ & Fri & 7.0 & & fine few & & medium \\
\hline
\end{tabular}

\section{A3T13 (31RD116)}

\begin{tabular}{|c|c|c|c|c|c|c|c|c|c|c|c|}
\hline & & Color & & & & & & & & & \\
\hline Horizon & Depth & Mottling & Moist & Texture & Structure & $\begin{array}{c}\text { Moist } \\
\text { Consistence }\end{array}$ & Reaction & Boundary & Roots & $\begin{array}{l}\text { Coarse } \\
\text { Fragments }\end{array}$ & Clay Skins \\
\hline $\mathrm{O}$ & $0-2$ & & $7.5 Y R 4 / 4$ & $\mathrm{~S}$ & $\bar{G}$ & $\mathrm{~L}$ & 7.0 & AS & fine many & & \\
\hline$A p$ & $2-25$ & & $7.5 Y R 4 / 4$ & $\bar{S}$ & $\bar{G}$ & $\bar{L}$ & 6.0 & AW & fine many & & \\
\hline $\mathrm{B}$ & 25-38 & $\begin{array}{l}\text { thin dark mineral } \\
\text { laminations }\end{array}$ & $7.5 Y R 5 / 4$ & $\mathrm{~S}$ & $\bar{G}$ & $L$ & 5.5 & AS & $\begin{array}{l}\text { fine few } \\
\text { medium }\end{array}$ & & \\
\hline$A b$ & $38-57$ & & $7.5 Y R 4 / 4$ & $\overline{S L}$ & $\overline{S B L}$ & Fri & 5.0 & CW & few & few fine pebbles & \\
\hline $\mathrm{Bb}$ & $57-90$ & $\begin{array}{c}\text { coarse common distinct } \\
\text { 10YR } 5 / 4\end{array}$ & $7.5 Y R 4 / 4$ & LS & $\overline{\mathrm{SBL}}$ & V. Fri & 6.5 to 7.0 & CW & few & & $\begin{array}{l}\text { rounded } \\
\text { pebbles }\end{array}$ \\
\hline $\mathrm{Bb}$ & $0->133$ & $\begin{array}{l}\text { many fine prominent } \\
10 Y R 5 / 6 \text { and } 5 Y R 3 / 3\end{array}$ & 10YR5/6 & LS & SBL & & 7.0 & & few & & \\
\hline
\end{tabular}




\begin{tabular}{|c|c|c|c|c|c|c|c|c|c|c|c|}
\hline & & Color & & & & & & & & & \\
\hline Horizon & Depth & Mottling & Moist & Texture & Structure & $\begin{array}{c}\text { Moist } \\
\text { Consistence }\end{array}$ & Reaction & Boundary & Roots & $\begin{array}{c}\text { Coarse } \\
\text { Fragments }\end{array}$ & Clay Skins \\
\hline 0 & $0-5$ & & 7.5YR5/4 & $S$ & & $\bar{L}$ & 6.0 & CS & fine many & $\begin{array}{l}\text { many fine to } \\
\text { coarse }\end{array}$ & \\
\hline Ap & $5-25$ & & $7.5 Y R 5 / 4$ & $\mathrm{~S}$ & platy & $\mathrm{L}$ & 5.0 to 4.5 & GW & fine many & & \\
\hline A & $25-33$ & & 7.5YR6/4 & $S$ & $\bar{G}$ & $\mathrm{~L}$ & 5.5 & $\overline{D l}$ & $\begin{array}{l}\text { fine few } \\
\text { medium }\end{array}$ & & \\
\hline $\mathrm{B}$ & $33-65$ & $2 \mathrm{~cm}$ bed of clean sand & 7.5 YR5/4 & $\mathrm{S}$ & $G$ & $\mathrm{~L}$ & 5.0 & CS & few & & \\
\hline $\mathrm{C}$ & $65-77$ & laminated & 7.5YR5/4 & $S$ & $\bar{G}$ & $\mathrm{~L}$ & 5.5 & $\mathrm{CW}$ & few & & \\
\hline$A b$ & $77-90$ & faint fine 5YR3/2 & $5 Y$ YR/3 & $\mathrm{L}$ & SBL & firm fri. & 6.5 to 7.0 & CW & few & & \\
\hline $\mathrm{Ab}$ & $90-105$ & faint fine $2.5 Y R 2.5 / 2$ & $2.5 Y R 2.5 / 2$ & $\mathrm{~L}$ & $\overline{\mathrm{SBL}}$ & firm fri. & 7.0 & DW & & & \\
\hline $\mathrm{Bb}$ & $105->130$ & distinct fine many $10 \mathrm{YR} 5 / 2$ & 7.5YR4/4 & $\mathrm{L}$ & SBL & firm fri. & 7.0 & & & & \\
\hline
\end{tabular}

\section{A8 Sandpit (31RD1173)}

\begin{tabular}{|c|c|c|c|c|c|c|c|c|c|c|c|}
\hline & \multicolumn{2}{|c|}{ Color } & \multirow[b]{2}{*}{ Texture } & \multirow[b]{2}{*}{ Structure } & \multirow[b]{2}{*}{$\begin{array}{c}\text { Moist } \\
\text { Consistence }\end{array}$} & \multirow[b]{2}{*}{ Reaction } & \multirow[b]{2}{*}{ Boundary } & \multirow[b]{2}{*}{ Roots } & \multirow[b]{2}{*}{$\begin{array}{c}\text { Coarse } \\
\text { Fragments }\end{array}$} & \multirow[b]{2}{*}{ Clay Skins } \\
\hline Horizon & Depth & & Moist & & & & & & & & \\
\hline Ap & $0-12$ & & 10YR3/6 & LS & MSBL & Fri & 6.5 & $\mathrm{CW}$ & fine many & & \\
\hline $\mathrm{B}$ & $12-35$ & & 10YR4/6 & LS & CSBL & $\mathrm{L}$ & 6.5 & AS & common fine & & \\
\hline $\mathrm{C}$ & $35-62$ & many fine $10 \mathrm{YR} 4 / 3$ & 10YR4/6 & LS & FSBL & $\mathrm{L}$ & 6.5 & AS & & & \\
\hline $\mathrm{Ab}$ & $62-85$ & many fine $10 \mathrm{YR} 2 / 1$ & 10YR4/6 & $\mathrm{SL}$ & $\mathrm{SBL}$ & $\mathrm{L}$ & 6.5 to 7.0 & $\mathrm{Gl}$ & few fine & & few thin \\
\hline $\mathrm{Bb}$ & $85->90$ & & $7.5 \mathrm{YR} 5 / 2$ & $\overline{S L}$ & $\mathrm{SBL}$ & $\bar{L}$ & 7.0 & & few fine & & few thin \\
\hline
\end{tabular}

A8T1 (31RD1173)

\begin{tabular}{|c|c|c|c|c|c|c|c|c|c|c|c|}
\hline & & Co & & & & & & & & & \\
\hline Horizon & Depth & Mottling & Moist & Texture & Structure & $\begin{array}{c}\text { Moist } \\
\text { Consistence }\end{array}$ & Reaction & Boundary & Roots & $\begin{array}{c}\text { Coarse } \\
\text { Fragments }\end{array}$ & Clay Skins \\
\hline$A p$ & $0-23$ & & 10YR5/3 & $\overline{S t L}$ & $\bar{G}$ & Firm & 6.0 & GW & fine many & & thin many \\
\hline $\bar{B}$ & $23-35$ & & 10YR3/4 & StL & SBL & Fri & 6.0 & GW & & & \\
\hline$A b$ & $35-50$ & & 10YR3/4 & $\overline{S L}$ & $\mathrm{SBL}$ & Fri & 6.5 to 7.0 & DW & & & \\
\hline $\mathrm{Bb}$ & $50-60$ & & 10YR3/4 & $\overline{\mathrm{SL}}$ & SBL & Fri & 6.5 to 7.0 & GW & & & \\
\hline $2 \mathrm{C}$ & $60->105$ & fine few $7.5 Y R 2 / 0$ & $7.5 \mathrm{YR} 4 / 6$ & $\mathrm{~L}$ & $\mathrm{CSBL}$ & Fri & 7.0 & & & & thin many \\
\hline
\end{tabular}


A8T5 (31RD1173)

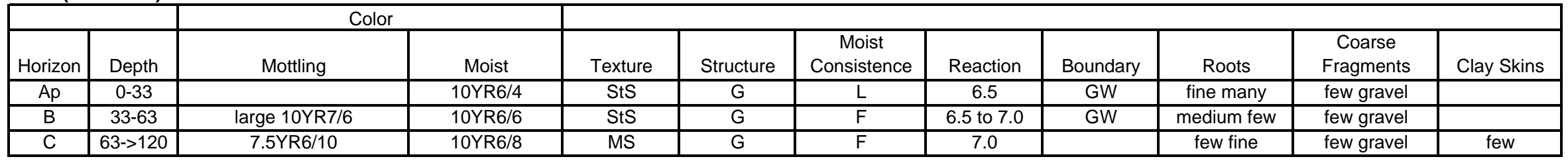

\section{A8T6 (31RD1173)}

\begin{tabular}{|c|c|c|c|c|c|c|c|c|c|c|c|}
\hline & \multicolumn{2}{|l|}{ Color } & \multirow[b]{2}{*}{ Texture } & \multirow[b]{2}{*}{ Structure } & \multirow[b]{2}{*}{$\begin{array}{c}\text { Moist } \\
\text { Consistence }\end{array}$} & \multirow[b]{2}{*}{ Reaction } & \multirow[b]{2}{*}{ Boundary } & \multirow[b]{2}{*}{ Roots } & \multirow[b]{2}{*}{$\begin{array}{c}\text { Coarse } \\
\text { Fragments }\end{array}$} & \multirow[b]{2}{*}{ Clay Skins } \\
\hline Horizon & Depth & Mottling & Moist & & & & & & & & \\
\hline Ap & $0-16$ & & 7.5YR 5/6 & $\mathrm{L}$ & G & $\mathrm{L}$ & 6.5 & GW & $\begin{array}{l}\text { many fine to } \\
\text { medium }\end{array}$ & & \\
\hline $\mathrm{B}$ & $16-28$ & fine many $10 \mathrm{YR} 5 / 8$ & 5YR 4/6 & $\mathrm{L}$ & FSBL & Fri & 7.0 & CS & common fine & & common thin \\
\hline C & $28-45$ & & $7.5 \mathrm{YR} 4 / 6$ & $\bar{L}$ & FSBL & Fri & 7.0 & CS & common fine & & common thin \\
\hline $\mathrm{Ab}$ & $45-55$ & root casts $7.5 Y R 3 / 4$ & 10YR 4/1 & $\overline{S t L}$ & FSBL & & 6.5 & DS & common fine & & few thin \\
\hline $\mathrm{Bb}$ & $55-77$ & many medium $\sim 50 \%$ & $5 / 1$ & $\bar{L}$ & $\overline{\mathrm{SBL}}$ & Fri & 7.0 & GW & common fine & & few thin \\
\hline $2 \mathrm{C}$ & $77->95$ & common coarse 10YR 5/8 & 10YR 5/1 & $\overline{\mathrm{SL}}$ & $\overline{\mathrm{SBL}}$ & Vfri & 7.0 & & common fine & & few thin \\
\hline
\end{tabular}

\begin{tabular}{|c|c|c|c|c|c|c|c|c|c|c|c|}
\hline & & & & & & & & & & & \\
\hline Horizon & Depth & Mottling & Moist & Texture & Structure & $\begin{array}{c}\text { Moist } \\
\text { Consistence }\end{array}$ & Reaction & Boundary & Roots & $\begin{array}{c}\text { Coarse } \\
\text { Fragments }\end{array}$ & Clay Skins \\
\hline$A p$ & $0-11$ & & 10YR 5/3 & LS & $\mathrm{F}$ & $\mathrm{F}$ & 5.5 & CS & many & few & few thin \\
\hline $\mathrm{B}$ & $11-27$ & & 7.5 YR 5/4 & LS & SBL & Fri & 5.5 & $\mathrm{CW}$ & some & few & \\
\hline $\mathrm{C}$ & $27-57$ & & 10YR 56/4 & $\overline{S L}$ & SBL & $\mathrm{F}$ & 5.5 & CW & some & few & \\
\hline $\mathrm{C}$ & $57-66$ & & 7.5YR 4/4 & LS & $\mathrm{G}$ & Fri & 5.5 & $\mathrm{CW}$ & few & & \\
\hline$A b$ & $66-73$ & & 7.5YR 3/1 & LS & $\mathrm{G}$ & Fri & 5.5 & $\mathrm{Cl}$ & some & & \\
\hline $\mathrm{Bb}$ & $73-90$ & feature at $73-82$ & 7.5YR 4/3 & LS & $\mathrm{G}$ & Vfri & 7.0 & & rare & & \\
\hline $\mathrm{C}$ & $90->105$ & & 7.5YR 4/4 & LS & & & & & & & \\
\hline
\end{tabular}


A9T12

\begin{tabular}{|c|c|c|c|c|c|c|c|c|c|c|c|}
\hline & & Colo & & & & & & & & & \\
\hline Horizon & Depth & Mottling & Moist & Texture & Structure & $\begin{array}{c}\text { Moist } \\
\text { Consistence }\end{array}$ & Reaction & Boundary & Roots & $\begin{array}{c}\text { Coarse } \\
\text { Fragments }\end{array}$ & Clay Skins \\
\hline$A p$ & $0-7$ & & 10YR 5/4 & $\overline{S L}$ & $\bar{G}$ & $\mathrm{~L}$ & 5.5 & CW & many & & \\
\hline $\bar{B}$ & $7-17$ & & 10YR 6/4 & StL & $\mathrm{G}$ & $\bar{L}$ & 5.5 & $\mathrm{CW}$ & many & & \\
\hline C & $17-40$ & & $\begin{array}{c}\text { 10YR 8/2 to } 2.5 \\
\text { YR } 4 / 4\end{array}$ & StL & $P$ & Vfri & 6.5 & $\mathrm{Cl}$ & few & & \\
\hline $\mathrm{C}$ & $40-55$ & & 10YR 6/3 & $\overline{\text { StL }}$ & $P$ & $\mathrm{~F}$ & 5.5 & $\mathrm{Cl}$ & few & & \\
\hline $\mathrm{C}$ & $55-61$ & & $7.5 Y R \quad 4 / 4$ & $\mathrm{~S}$ & $\bar{G}$ & Fri & 5.5 & $\mathrm{CW}$ & & occasional & \\
\hline$A b$ & $61-80$ & & $7.5 Y R 4 / 3$ & $\mathrm{SL}$ & $\mathrm{SBL}$ & Fri & 6.0 & GW & few & occasional & \\
\hline $\mathrm{B}$ & $80-91$ & many medium $\sim 50 \%$ & $7.5 Y R \quad 4 / 4$ & $\overline{\mathrm{SL}}$ & $\overline{\mathrm{SBL}}$ & Fri & 6.5 & GW & & & \\
\hline C & $9->117$ & many medium $\sim 50 \%$ & 7.5YR 4/6 & SL & SBL & Fri & 7.0 & & & & \\
\hline
\end{tabular}


A2T1 31RD1163

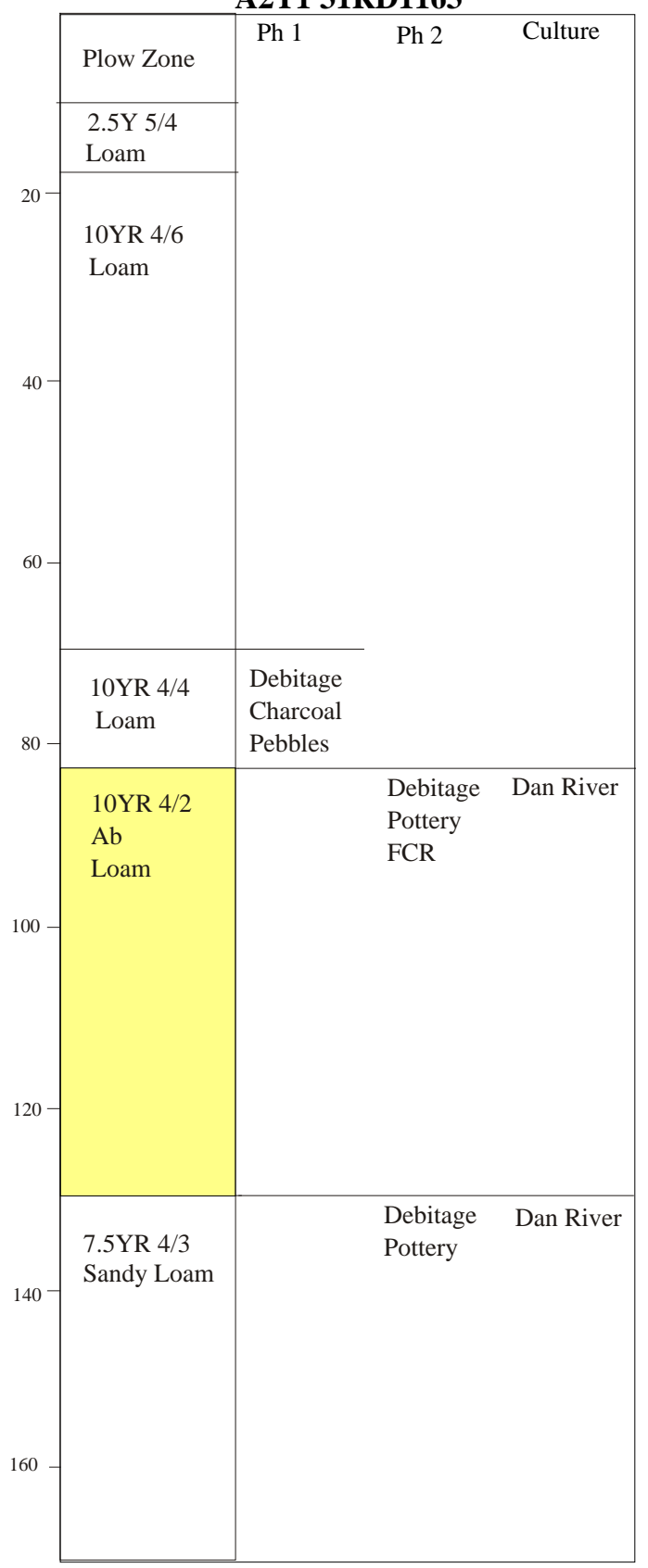

A2T7 31RD1164

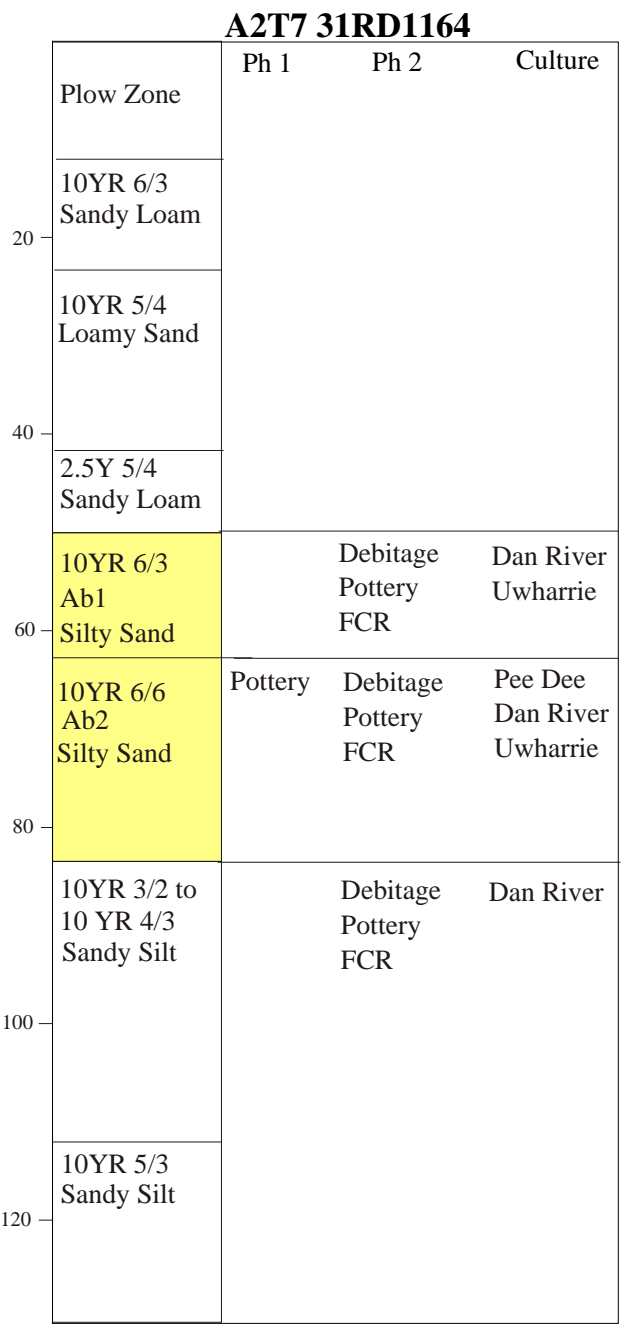


A3T14 31RD128

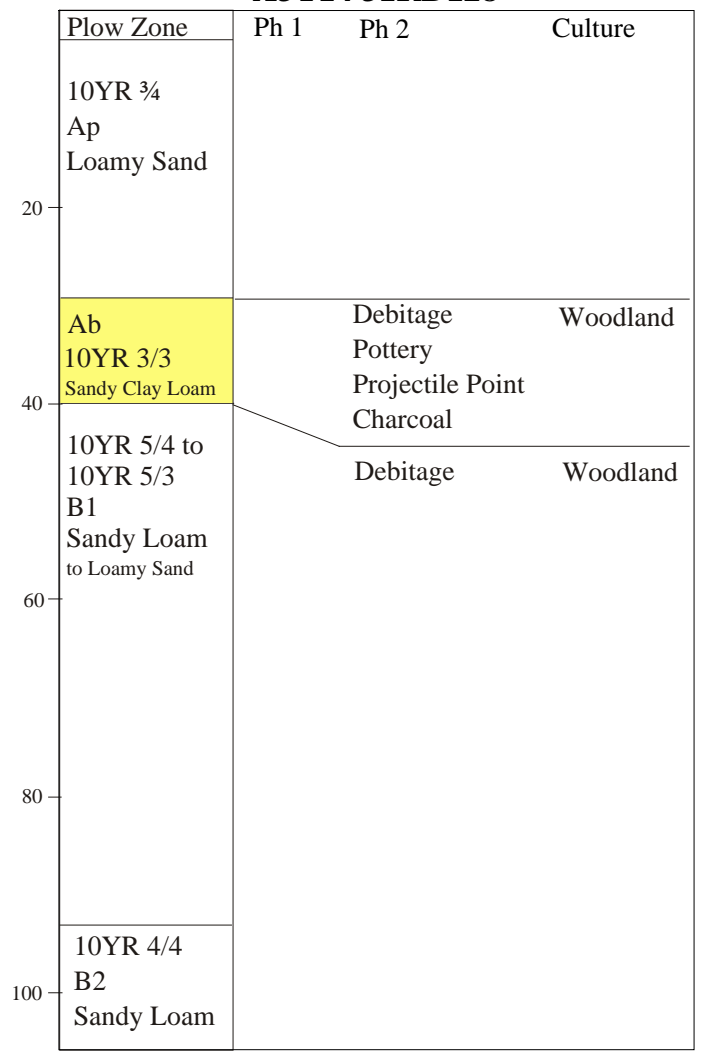

A9T5 31GF376

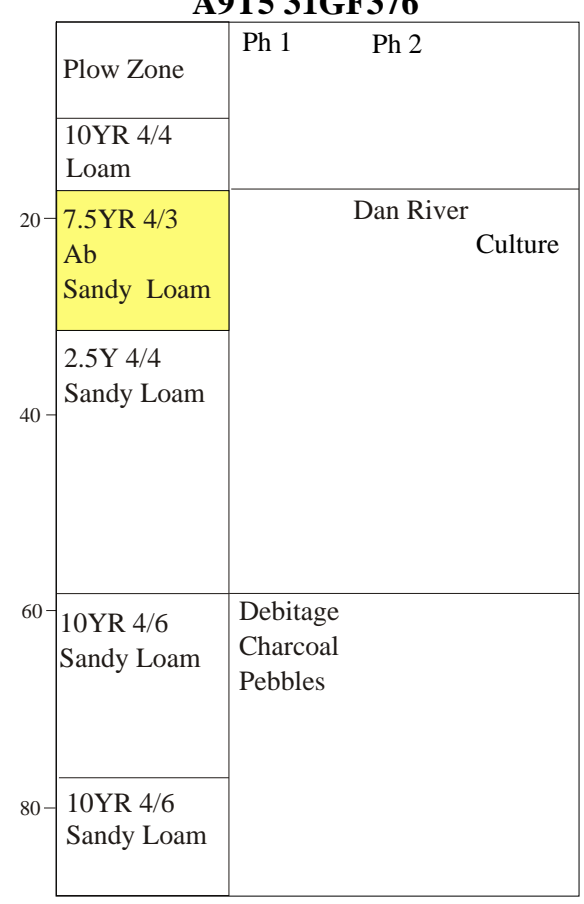


A8T2 31RD1173

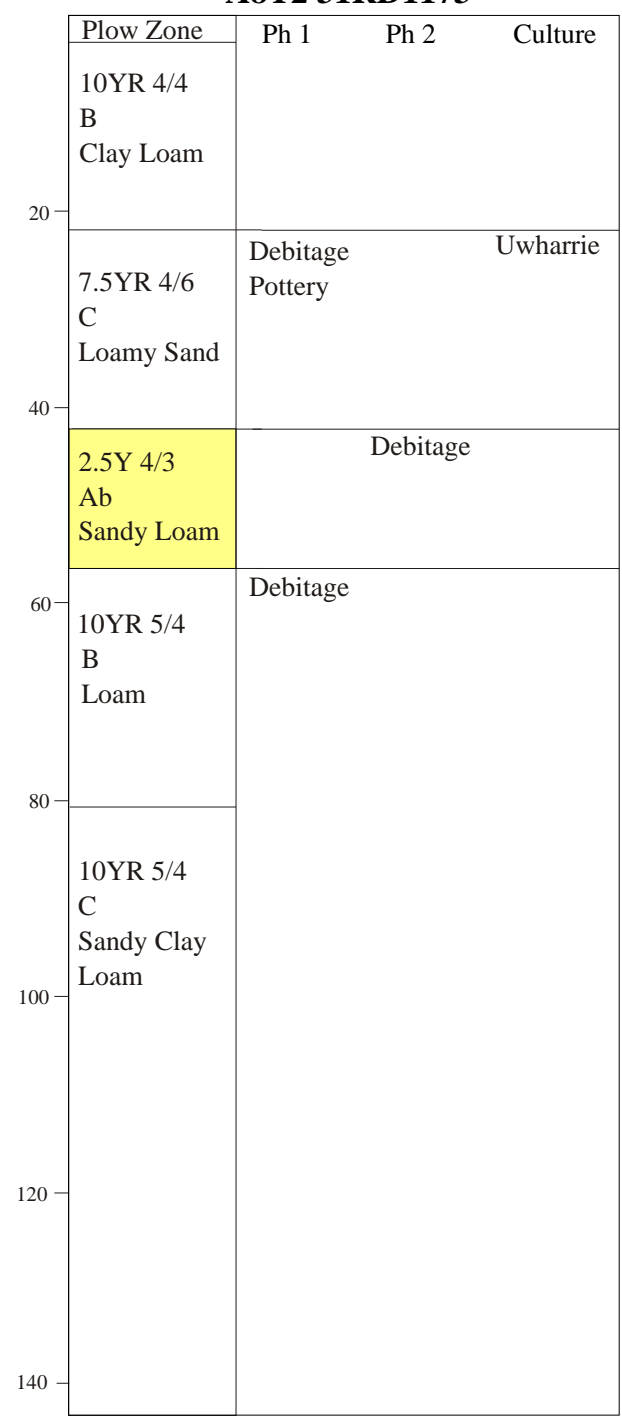




\section{APPENDIX II}

Procedure for Measuring Magnetic Susceptibility 
Introduction

The Bison Magnetic Susceptibility Meter Model 3101 is based on a design by Mooney (1952). The Susceptibility Meter measures in the range of 0.00001 to $0.1 \mathrm{cgs}$ units (Bison Instruments, 1970). Generally, this range includes all naturally occurring materials however, higher values can be measured as well (Bison Instruments, 1970).

Measurements made with the meter are made in a magnetic field whose intensity is approximately equal to that of earth's magnetic field (Bison Instruments, 1970). Because the magnetic susceptibility of ferrimagnetic materials depends on field strength, high field strengths would be practically useless for magnetic surveys (Bison Instruments, 1970). The susceptibility meter measures materials independent of the remnant magnetization and, except for highly conducting materials, of the conductivity of the sample (Bison Instruments, 1970). This feature is especially important because the majority of materials that can be magnetized exhibit induced magnetism (i.e., susceptibility) and remnant magnetization (Bison Instruments, 1970). The induced magnetism and the remnant magnetism is successfully separated using the Bison Magnetic Susceptibility Meter (Bison Instruments, 1970).

Sample Preparation

Empty the contents of a sample bag onto a sample-splitter pan. If sample is semiconsolidated, it may need to be disaggregated (crumble by hand, do NOT crush particles), in order to pass freely through the sample splitter. Split samples several times until a suitable quantity is retained. 
Analysis

The Bison meter should be placed on a flat, horizontial, stable surface. Operating is carried out in two steps. The first step consists of a null adjustment which is made by placing a plastic test tube from the Bison meter on the scale and calibrating the scale to read zero. NOTE: DO NOT forget to zero the scale before adding each and every sample! From the split sample, measure exactly $30 \mathrm{~g}$ of sediment for analysis. Because magnetic susceptibility measurements are in CGS units, the measurement is weight dependent. Any variations in sample weight from $30 \mathrm{~g}$ will cause measurements to be incomparable. Store any remaining sample.

Next, the sample is inserted into the specimen sampler and final adjustments made (Air Balance). Each Bison Magnetic Susceptibility Bridge is individually calibrated at the factory so that the reading on the dial is directly converted into magnetic susceptibility units (Bison Instruments, 1970). Record reading on lab sheet and discard the measured sample. For more detailed instruction, refer to the Bison Magnetic Susceptibility Meter Model 3101 instruction manual (Bison Instruments, 1970).

\section{References}

Bison Instruments, 1970, Bison magnetic susceptibility system 3101: Instruction Manual; Bison Instruments, St. Louis, Missouri, 10 p. 


\section{APPENDIX III}

Particle-size Analysis 
Particle-size analysis was completed using standard lab techniques. The samples were first prepared for particle-size analysis. Preparation included whole-sample splitting, drying, weighing, organic-matter removal, dispersion, and wet sieving with a $63 \mu$ (230 mesh) sieve. The coarse fraction was dry sieved into -1.0, 0.0, 1.0, 2.0, 3.0, and 4.0 phi intervals and saved for future analysis. These steps were done at the West Virginia University Quaternary Lab and in accordance with West Virginia University Quaternary Lab standards (Bell, 1986). The fine fraction was taken to the Appalachian State University Sedimentology Lab in Boone, North Carolina, where it was placed in a sonic dismembraner to help disaggregate the sample and then analyzed using a Sedigraph 5100.

\section{SediGraph 5100}

Before using the Sedigraph, there are a few preparatory steps. First, a baseline sample is run. Use of the Sedigraph 5100 requires that "each dispersion powder be well dispersed in a liquid of known density and viscosity and that differences between powder and liquid densities be accurately known" (Sedigraph, 1989). To obtain the most accurate analysis, a sample dispersion with the appropriate concentration level must be used (Sedigraph, 1989). Next, an information file must be assigned to the sample. The file consists of information, which identify the sample, guide the analysis, and specify types of data reduction. The ultrasonic probe is then placed into the sample and run for about 3 min. Care should be taken to avoid generating bubbles, which cause misleading results if trapped in the liquid during agitation. Finally, the sample is poured into the mixing 
chamber for analysis. A magnetic stirrer built into the instrument is a convenient means for maintaining homogeneous particle dispersion.

The Sedigraph 5100 generates a cumulative percent particle-size curve for siltand clay-sized particles using Stokes Law. Each sample can be analyzed in approximately 30 minutes with the Sedigraph.

\section{Statistical Analysis}

A cumulative percent curve was generated from the data obtained from the dry fraction sieve analysis and from the Sedigraph 5100. The cumulative percent curve allows the diameter of the particles to be represented as cumulative percentages (i.e. the phi measurement that corresponds with the $50 \%$ mark indicates that $50 \%$ of the material is coarser than that diameter). The median, graphic mean and graphic standard deviation were determined from the curve. The statistics used in the calculations are based on Folk (1980). The median is the 50-percentile on the cumulative curve. This measurement does not take into account skewness of the distribution. Graphic mean $((16 \phi+50 \phi+$ $84 \phi) / 3$ ) is based on three points and, therefore, gives a better overall picture of particlesize properties. The standard deviation was calculated using $(84 \phi-16 \phi) / 2$. Hence, this sorting measurement evaluates the central $68 \%$ of the particle-size distribution. 


\section{References}

Bell, Alison M., 1986, Morphology and stratigraphy of terraces in the upper Shenandoah Valley, Virginia (M.S. thesis): Morgantown, West Virginia University, 161 p.

Bison Instruments, 1970, Bison magnetic susceptibility system 3101: Instruction Manual; Bison Instruments, St. Louis, Missouri, 10 p.

Folk, R.L., 1980, Petrology of sedimentary rocks: Hemphill's, Austin, Texas, 184 p.

SediGraph 5100, 1989, SediGraph 5100: Instruction Manual; Norcross, Georgia, 355 p. 


\section{APPENDIX IV}

Sedimentological Data

Lab data and Statistics 


\begin{tabular}{|c|c|c|c|c|c|c|c|c|c|c|c|c|c|c|c|c|c|c|c|}
\hline \multicolumn{2}{|c|}{ Historic sediment } & \multicolumn{2}{|c|}{ Prehistoric sediment } & & & & & & & \multirow[b]{2}{*}{ Weight } & \multirow[b]{2}{*}{ Weight } & \multirow[b]{2}{*}{ Weight } & \multirow[b]{2}{*}{ Weight } & \multirow[b]{2}{*}{ Weight } & \multirow[b]{2}{*}{ Weight } & \multirow[b]{2}{*}{ Weight } & \multirow[b]{2}{*}{ Weight } & \multirow[b]{2}{*}{ Weight } & \multirow[b]{2}{*}{ Weight } \\
\hline & & & & & & & $\begin{array}{l}\text { Percent } \\
\text { Sand }\end{array}$ & \begin{tabular}{|c|}
$\begin{array}{c}\text { Percent } \\
\text { Silt }\end{array}$ \\
\end{tabular} & $\begin{array}{c}\text { Percent } \\
\text { Clay }\end{array}$ & & & & & & & & & & \\
\hline \begin{tabular}{|l|} 
Depth \\
\end{tabular} & $\begin{array}{c}\text { Area } \\
\text { Location }\end{array}$ & \begin{tabular}{|l|} 
Trench \\
Number
\end{tabular} & \begin{tabular}{|l|} 
Site Number \\
\end{tabular} & $\begin{array}{c}\text { Sample } \\
\text { Wt. }\end{array}$ & $\begin{array}{c}\text { Coarse } \\
\text { Wt. }\end{array}$ & Fine Wt. & $\begin{array}{c}<-1.0 \text { to } 4.0 \\
\text { phi }\end{array}$ & $\begin{array}{c}<4.0-8.0 \\
\text { phi }\end{array}$ & $\begin{array}{c}<8.0-<9 \\
\text { phi }\end{array}$ & $\begin{array}{c}-1.0 \text { phi and } \\
\text { greater }\end{array}$ & $\begin{array}{c}<-1.0-0.0 \\
\text { phi }\end{array}$ & $\begin{array}{c}<0-1.0 \\
\text { phi }\end{array}$ & $\begin{array}{c}<1.0-2.0 \\
\text { phi }\end{array}$ & $\begin{array}{c}<2.0-3.0 \\
\text { phi }\end{array}$ & $\begin{array}{c}<3.0-4.0 \\
\mathrm{phi}\end{array}$ & $\begin{array}{c}<4.0-5.0 \\
\mathrm{phi}\end{array}$ & \begin{tabular}{|c|}
$<<5.0-6.0$ \\
$\mathrm{phi}$
\end{tabular} & $\begin{array}{c}<6.0-7.0 \\
\mathrm{phi}\end{array}$ & $\begin{array}{c}<7.0-8.0 \\
\text { phi }\end{array}$ \\
\hline $0-5$ & A2 & $\mathrm{T} 1$ & \begin{tabular}{|l|}
$31 \mathrm{RD} 1163$ \\
\end{tabular} & 24.88 & 8.11 & 16.77 & 32.44 & & & 0.04 & 0.02 & 0.07 & 0.46 & 2.71 & 4.80 & & & & \\
\hline 10 & $\mathrm{~A} 2$ & $\mathrm{~T} 1$ & 31RD1163 & 30.78 & 11.02 & 19.76 & 35.80 & 42.31 & 21.96 & 0.00 & 0.03 & 0.13 & 0.81 & 4.36 & 5.88 & 24.70 & 21.40 & 12.00 & 7.80 \\
\hline 20 & $\mathrm{~A} 2$ & $\mathrm{~T} 1$ & 31RD1163 & 34.92 & 14.77 & 20.15 & 42.29 & 39.30 & 18.47 & 0.00 & 0.02 & 0.13 & 1.45 & 6.14 & 7.00 & 27.40 & 21.90 & 11.70 & 7.10 \\
\hline 30 & $\mathrm{~A} 2$ & $\mathrm{T1}$ & \begin{tabular}{|l|} 
31RD1163 \\
\end{tabular} & 37.00 & 16.19 & 20.81 & 43.75 & 39.82 & 16.42 & 0.00 & 0.07 & 0.19 & 1.89 & 6.88 & 7.27 & 30.40 & 22.50 & 11.40 & 6.50 \\
\hline 40 & A2 & $\mathrm{T} 1$ & \begin{tabular}{|l|} 
31RD1163 \\
\end{tabular} & 33.12 & 14.05 & 19.07 & 42.39 & 40.61 & 16.94 & 0.01 & 0.02 & 0.06 & 1.09 & 5.93 & 6.91 & 31.00 & 22.40 & 10.30 & 6.80 \\
\hline 50 & $\mathrm{~A} 2$ & T1 & \begin{tabular}{|l|}
31 RD1163 \\
\end{tabular} & 34.93 & 13.9 & 21.03 & 39.80 & 42.44 & 17.76 & 0.00 & 0.02 & 0.06 & 0.93 & 5.81 & 6.93 & 27.70 & 23.60 & 12.30 & 6.90 \\
\hline 60 & $\mathrm{~A} 2$ & $\mathrm{T1}$ & \begin{tabular}{|l|}
$31 \mathrm{RD} 1163$ \\
\end{tabular} & 24.93 & 10.46 & 14.47 & 41.96 & 41.21 & 16.83 & 0.00 & 0.03 & 0.03 & 0.67 & 4.58 & 5.13 & 29.80 & 22.60 & 11.90 & 6.70 \\
\hline 70 & $\mathrm{~A} 2$ & $\mathrm{~T} 1$ & \begin{tabular}{|l|}
$31 \mathrm{RD} 1163$ \\
\end{tabular} & 28.31 & 16.44 & 11.87 & 58.07 & 28.98 & 13.00 & 0.00 & 0.00 & 0.03 & 1.64 & 8.30 & 6.40 & 31.60 & 21.10 & 10.00 & 6.40 \\
\hline 80 & $\mathrm{~A} 2$ & $\mathrm{~T} 1$ & \begin{tabular}{|l|}
31 RD1163 \\
\end{tabular} & 32.94 & 15.99 & 16.95 & 48.55 & 34.83 & 16.62 & 0.00 & 0.05 & 0.04 & 1.16 & 7.13 & 7.60 & 29.60 & 20.70 & 11.10 & 6.30 \\
\hline 90 & A2 & $\mathrm{T} 1$ & \begin{tabular}{|c|} 
31RD1163 \\
\end{tabular} & 25.49 & 13 & 12.49 & 51.00 & & & 0.00 & 0.01 & 0.05 & 0.78 & 5.55 & 6.53 & & & & \\
\hline 100 & A2 & T1 & \begin{tabular}{|c|}
31 RD1163 \\
\end{tabular} & 35.00 & 16.31 & 18.69 & 46.60 & 36.47 & 16.93 & 0.00 & 0.05 & 0.06 & 0.83 & 6.40 & 8.87 & 32.10 & 21.00 & 9.90 & 5.30 \\
\hline 110 & $\mathrm{~A} 2$ & $\mathrm{T1}$ & \begin{tabular}{|c|}
$31 \mathrm{RD} 1163$ \\
\end{tabular} & 28.93 & 13.96 & 14.97 & 48.26 & 35.24 & 16.45 & 0.00 & 0.02 & 0.04 & 0.73 & 5.94 & 7.28 & 31.90 & 20.40 & 10.00 & 5.80 \\
\hline 120 & $\mathrm{~A} 2$ & $\mathrm{T1}$ & \begin{tabular}{|l|}
$31 \mathrm{RD} 1163$ \\
\end{tabular} & 30.18 & 16.69 & 13.49 & 55.31 & 32.31 & 12.38 & 0.00 & 0.00 & 0.02 & 0.99 & 7.48 & 8.18 & 36.60 & 20.80 & 9.70 & 5.20 \\
\hline 130 & $\mathrm{~A} 2$ & $\mathrm{~T} 1$ & \begin{tabular}{|c|}
31 RD1163 \\
\end{tabular} & 25.76 & 16.12 & 9.64 & 62.57 & 23.09 & 0.00 & 0.00 & 0.04 & 0.01 & 1.29 & 7.70 & 7.02 & 37.10 & 19.20 & 5.40 & \\
\hline 140 & A2 & T1 & \begin{tabular}{|l|} 
31RD1163 \\
\end{tabular} & 31.71 & 22.11 & 9.60 & 69.72 & 21.74 & 8.54 & 0.00 & 0.01 & 0.05 & 3.16 & 11.25 & 7.53 & 38.20 & 19.60 & 8.70 & 5.30 \\
\hline 150 & A2 & T1 & \begin{tabular}{|c|} 
31RD1163 \\
\end{tabular} & 30.94 & 20.31 & 10.63 & 65.65 & & & 0.00 & 0.00 & 0.05 & 3.12 & 10.25 & 6.90 & & & & \\
\hline $0-5$ & $\bar{A} 2$ & 77 & \begin{tabular}{|l|} 
31RD1164 \\
\end{tabular} & 26.83 & 15.89 & 10.94 & 58.70 & & & 0.14 & 0.26 & 1.21 & 4.44 & 5.37 & 4.40 & & & & \\
\hline 10 & A2 & 77 & \begin{tabular}{|c|} 
31RD1164 \\
\end{tabular} & 29.37 & 17.08 & 12.29 & 57.58 & 31.14 & 11.33 & 0.17 & 0.29 & 1.02 & 4.33 & 6.00 & 5.36 & 34.70 & 22.20 & 10.80 & 5.70 \\
\hline 20 & A2 & $\mathrm{T7}$ & \begin{tabular}{|c|}
$31 \mathrm{RD} 1164$ \\
\end{tabular} & 33.84 & 20.04 & 13.80 & 59.08 & 29.26 & 11.62 & 0.05 & 0.24 & 1.22 & 4.98 & 7.17 & 6.24 & 33.00 & 22.80 & 10.60 & 5.10 \\
\hline 30 & $\mathrm{~A} 2$ & $\mathrm{T7}$ & 31RD1164 & 34.92 & 21.73 & 13.19 & 61.71 & 28.49 & 9.80 & 0.18 & 0.25 & 1.35 & 5.30 & 7.75 & 6.78 & 36.50 & 23.10 & 9.90 & 4.90 \\
\hline 40 & $\mathrm{~A} 2$ & $\mathrm{~T} 7$ & \begin{tabular}{|l|}
$31 \mathrm{RD} 1164$ \\
\end{tabular} & 27.50 & 23.3 & 4.20 & 84.58 & 11.61 & 3.81 & 0.04 & 0.26 & 1.44 & 5.81 & 8.37 & 7.21 & 37.50 & 23.30 & 10.10 & 4.40 \\
\hline 50 & A2 & $\mathrm{T7}$ & \begin{tabular}{|l|} 
31RD1164 \\
\end{tabular} & 33.50 & 20.1 & 13.40 & 59.73 & 29.07 & 11.15 & 0.09 & 0.19 & 1.30 & 5.85 & 6.87 & 5.71 & 30.70 & 22.90 & 12.60 & 6.00 \\
\hline 60 & A2 & T7 & \begin{tabular}{|l|} 
31RD1164 \\
\end{tabular} & 33.71 & 22.21 & 11.50 & 65.77 & 25.36 & 8.83 & 0.04 & 0.16 & 1.44 & 8.06 & 7.50 & 4.80 & 34.10 & 23.10 & 11.30 & 5.60 \\
\hline 70 & A2 & $\mathrm{T7}$ & \begin{tabular}{|c|} 
31RD1164 \\
\end{tabular} & 41.71 & 24.3 & 17.41 & 58.19 & 30.36 & 11.46 & 0.03 & 0.21 & 1.69 & 7.13 & 8.11 & 7.02 & 30.10 & 22.80 & 12.90 & 6.80 \\
\hline 80 & $\mathrm{~A} 2$ & $\mathrm{~T} 7$ & \begin{tabular}{|c|}
$31 \mathrm{RD} 1164$ \\
\end{tabular} & 35.45 & 18.25 & 17.20 & 51.26 & 37.48 & 11.21 & 0.08 & 0.20 & 1.04 & 3.67 & 6.32 & 6.99 & 35.20 & 23.30 & 12.10 & 6.30 \\
\hline 90 & $\mathrm{~A} 2$ & $\mathrm{T7}$ & \begin{tabular}{|l|} 
31RD1164 \\
\end{tabular} & 38.54 & 18.82 & 19.72 & 48.78 & 37.60 & 13.57 & 0.02 & 0.21 & 1.18 & 3.52 & 6.43 & 7.31 & 31.00 & 22.80 & 12.70 & 6.90 \\
\hline 100 & $\mathrm{~A} 2$ & $\mathrm{T7}$ & \begin{tabular}{|c|}
$31 \mathrm{RD} 1164$ \\
\end{tabular} & 33.70 & 17 & 16.70 & 46.49 & 37.08 & 16.43 & 1.33 & 0.30 & 1.14 & 3.18 & 5.14 & 5.88 & 26.80 & 23.00 & 12.80 & 6.70 \\
\hline 110 & A2 & $\mathrm{T7}$ & \begin{tabular}{|l|} 
31RD1164 \\
\end{tabular} & 41.22 & 21.03 & 20.19 & 48.35 & 36.31 & 15.29 & 1.10 & 0.65 & 1.80 & 3.82 & 6.32 & 7.20 & 26.90 & 22.60 & 13.60 & 7.20 \\
\hline 120 & A2 & $\mathrm{T7}$ & \begin{tabular}{|l|} 
31RD1164 \\
\end{tabular} & 33.13 & 17.16 & 15.97 & 47.09 & 37.56 & 15.29 & 1.56 & 0.66 & 1.41 & 2.97 & 4.90 & 5.57 & 30.10 & 22.00 & 12.70 & 6.20 \\
\hline $10-15$ & $\bar{A} 3$ & T8 & \begin{tabular}{|l|} 
31RD1166 \\
\end{tabular} & 25.97 & 28.03 & -2.06 & & & & 0.09 & 0.24 & 0.40 & 7.32 & 16.44 & 3.83 & & & & \\
\hline $20-25$ & $\mathrm{~A} 3$ & T8 & \begin{tabular}{|c|} 
31RD1166 \\
\end{tabular} & 26.49 & 17.48 & 9.01 & 65.77 & 25.88 & 8.32 & 0.06 & 0.27 & 0.52 & 2.80 & 8.29 & 5.34 & 36.50 & 21.10 & 11.60 & 6.40 \\
\hline $30-35$ & $\mathrm{~A} 3$ & T8 & \begin{tabular}{|c|}
$31 \mathrm{RD} 1166$ \\
\end{tabular} & 35.64 & 23.8 & 11.84 & 66.60 & 25.75 & 7.65 & 0.06 & 0.97 & 1.13 & 2.67 & 7.35 & 8.07 & 38.70 & 21.20 & 10.90 & 6.30 \\
\hline $40-45$ & $\mathrm{~A} 3$ & $\mathrm{~T} 8$ & \begin{tabular}{|l|}
$31 \mathrm{RD} 1166$ \\
\end{tabular} & 40.70 & 22.43 & 18.27 & 54.70 & 32.30 & 13.00 & 0.17 & 0.73 & 1.10 & 3.21 & 8.29 & 8.95 & 31.90 & 21.40 & 11.40 & 6.60 \\
\hline $50-55$ & $\mathrm{~A} 3$ & $\mathrm{~T} 8$ & \begin{tabular}{|l|} 
31RD1166 \\
\end{tabular} & 35.91 & 17.22 & 18.69 & 44.47 & 32.98 & 22.60 & 1.25 & 0.49 & 0.61 & 2.70 & 6.07 & 6.13 & 25.80 & 17.80 & 9.80 & 6.00 \\
\hline $60-65$ & $\mathrm{~A} 3$ & T8 & \begin{tabular}{|c|} 
31RD1166 \\
\end{tabular} & 38.29 & 17.69 & 20.60 & 44.01 & & & 0.84 & 0.42 & 0.58 & 3.09 & 6.48 & 6.17 & & & & \\
\hline $70-75$ & $\mathrm{~A} 3$ & T8 & \begin{tabular}{|c|} 
31RD1166 \\
\end{tabular} & 37.91 & 21.15 & 16.76 & 54.86 & 24.10 & 20.99 & 0.35 & 0.49 & 0.56 & 3.79 & 7.34 & 6.19 & 23.40 & 15.10 & 8.60 & 6.30 \\
\hline \begin{tabular}{|l|}
$80-85$ \\
\end{tabular} & $\mathrm{~A} 3$ & T8 & \begin{tabular}{|c|}
$31 \mathrm{RD} 1166$ \\
\end{tabular} & 33.85 & 18.32 & 15.53 & 51.53 & 22.64 & 23.07 & 0.88 & 0.96 & 0.49 & 3.50 & 7.15 & 5.37 & 19.70 & 12.60 & 8.40 & 6.00 \\
\hline \begin{tabular}{|l|}
$85-90$ \\
\end{tabular} & $\mathrm{~A} 3$ & T8 & \begin{tabular}{|l|} 
31RD1166 \\
\end{tabular} & 32.40 & 21.73 & 10.67 & 54.56 & 16.27 & 29.22 & 4.05 & 7.77 & 1.25 & 1.81 & 3.80 & 3.03 & 14.30 & 9.70 & 6.70 & 5.10 \\
\hline \begin{tabular}{|l|}
$90-95$ \\
\end{tabular} & $\mathrm{~A} 3$ & T8 & \begin{tabular}{|c|} 
31RD1166 \\
\end{tabular} & 31.28 & 17.15 & 14.13 & 53.14 & 16.96 & 29.85 & 0.53 & 1.01 & 0.47 & 3.53 & 6.85 & 4.70 & 14.90 & 9.60 & 6.50 & 5.20 \\
\hline \begin{tabular}{|l|}
$100-105$ \\
\end{tabular} & $\mathrm{~A} 3$ & T8 & \begin{tabular}{|c|} 
31RD1166 \\
\end{tabular} & 45.56 & 26.41 & 19.15 & 57.68 & 15.74 & 26.62 & 0.13 & 0.22 & 0.71 & 6.33 & 11.73 & 7.31 & 15.10 & 10.50 & 6.30 & 5.30 \\
\hline $5-7$ & $\mathrm{~A} 3$ & $\mathrm{~T} 13$ & \begin{tabular}{|l|}
31 RD1166 \\
\end{tabular} & 32.53 & 28.28 & 4.25 & 86.94 & & & 0.00 & 0.12 & 1.34 & 14.04 & 10.67 & 2.11 & & & & \\
\hline \begin{tabular}{|c|}
$18-20$ \\
\end{tabular} & $\mathrm{~A} 3$ & T13 & \begin{tabular}{|l|} 
31RD1166 \\
\end{tabular} & 46.12 & 42.31 & 3.81 & 91.72 & & & 0.01 & 0.06 & 1.44 & 22.54 & 15.88 & 2.35 & & & & \\
\hline $34-36$ & $\mathrm{~A} 3$ & T13 & \begin{tabular}{|c|} 
31RD1166 \\
\end{tabular} & 48.33 & 45.18 & 3.15 & 93.48 & 3.96 & 2.55 & 0.00 & 0.06 & 0.53 & 16.67 & 24.21 & 3.71 & 28.50 & 15.30 & 10.00 & 7.00 \\
\hline \begin{tabular}{|c|}
$38-40$ \\
\end{tabular} & A3 & T13 & \begin{tabular}{|l|} 
31RD1166 \\
\end{tabular} & 45.22 & 28.98 & 16.24 & 64.09 & 27.97 & 6.75 & 0.00 & 0.17 & 0.43 & 2.53 & 12.82 & 12.93 & 40.10 & 21.70 & 10.00 & 6.10 \\
\hline $46-48$ & $\mathrm{~A} 3$ & T13 & 31RD1166 & 37.17 & 24.12 & 13.05 & 64.74 & 28.00 & 5.04 & 0.06 & 0.20 & 0.37 & 2.18 & 10.86 & 10.63 & 43.00 & 20.40 & 10.20 & 5.80 \\
\hline $55-57$ & $\mathrm{~A} 3$ & $T 13$ & \begin{tabular}{|l|}
$31 \mathrm{RD} 1166$ \\
\end{tabular} & 25.94 & 16.43 & 9.51 & 63.10 & 29.08 & 7.23 & 0.06 & 0.15 & 0.37 & 1.61 & 7.29 & 7.05 & 43.50 & 19.70 & 9.30 & 6.30 \\
\hline
\end{tabular}




\begin{tabular}{|c|c|c|c|c|c|c|c|c|c|c|c|c|c|c|c|c|c|c|c|}
\hline \multicolumn{2}{|c|}{ Historic sediment } & \multicolumn{2}{|c|}{ Prehistoric sediment } & & & & & & & \multirow[b]{2}{*}{ Weight } & \multirow[b]{2}{*}{ Weight } & \multirow[b]{2}{*}{ Weight } & \multirow[b]{2}{*}{ Weight } & \multirow[b]{2}{*}{ Weight } & \multirow[b]{2}{*}{ Weight } & \multirow[b]{2}{*}{ Weight } & \multirow[b]{2}{*}{ Weight } & \multirow[b]{2}{*}{ Weight } & \multirow[b]{2}{*}{ Weight } \\
\hline & & & & & & & $\begin{array}{c}\text { Percent } \\
\text { Sand }\end{array}$ & \begin{tabular}{|c|} 
Percent \\
Silt
\end{tabular} & $\begin{array}{c}\text { Percent } \\
\text { Clay }\end{array}$ & & & & & & & & & & \\
\hline \begin{tabular}{|l|l} 
Depth \\
\end{tabular} & $\begin{array}{c}\text { Area } \\
\text { Location }\end{array}$ & \begin{tabular}{|l|} 
Trench \\
Number
\end{tabular} & Site Number & $\begin{array}{c}\text { Sample } \\
\text { Wt. }\end{array}$ & $\begin{array}{c}\text { Coarse } \\
\text { Wt. }\end{array}$ & Fine Wt. & $\begin{array}{c}<-1.0 \text { to } 4.0 \\
\text { phi }\end{array}$ & $\begin{array}{c}<4.0-8.0 \\
\text { phi }\end{array}$ & $\begin{array}{c}<8.0-<9 \\
\text { phi }\end{array}$ & \begin{tabular}{|c|}
-1.0 phi and \\
greater
\end{tabular} & $\begin{array}{c}<-1.0-0.0 \\
\text { phi }\end{array}$ & $\begin{array}{c}<0-1.0 \\
\text { phi }\end{array}$ & $\begin{array}{c}<1.0-2.0 \\
\text { phi }\end{array}$ & $\begin{array}{c}<2.0-3.0 \\
\text { phi }\end{array}$ & $\begin{array}{c}<3.0-4.0 \\
\text { phi }\end{array}$ & $\begin{array}{c}<4.0-5.0 \\
\text { phi }\end{array}$ & \begin{tabular}{|c|}
$<5.0-6.0$ \\
phi
\end{tabular} & \begin{tabular}{|c|}
$<6.0-7.0$ \\
phi
\end{tabular} & $\begin{array}{c}<7.0-8.0 \\
\text { phi }\end{array}$ \\
\hline $70-75$ & $\mathrm{~A} 3$ & $\mathrm{~T} 13$ & 31RD1166 & 46.75 & 34.92 & 11.83 & 74.41 & 20.34 & 4.38 & 0.13 & 0.38 & 0.72 & 2.93 & 12.89 & 12.76 & 42.30 & 20.90 & 10.60 & 5.70 \\
\hline $85-90$ & $\mathrm{~A} 3$ & $T 13$ & 31RD1166 & 51.67 & 24.81 & 26.86 & 47.90 & 38.03 & 14.07 & 0.06 & 0.40 & 0.98 & 4.10 & 14.20 & 12.49 & 35.50 & 20.90 & 10.50 & 6.10 \\
\hline 105-110 & $\mathrm{A} 3$ & $T 13$ & 31RD1166 & 38.33 & 20.41 & 17.92 & 49.38 & 30.42 & 20.25 & 1.48 & 0.36 & 0.72 & 3.02 & 7.73 & 7.05 & 27.30 & 17.30 & 9.50 & 6.00 \\
\hline 125-130 & $\mathrm{A} 3$ & $\mathrm{~T} 13$ & 31RD1166 & 41.76 & 20.5 & 21.26 & 48.61 & 25.59 & 22.41 & 0.20 & 0.27 & 1.27 & 4.66 & 7.51 & 6.39 & 20.00 & 14.10 & 8.80 & 6.90 \\
\hline $20-25$ & $\mathrm{~A} 3$ & $\mathrm{~T} 14$ & 31RD128 & 41.61 & 33.79 & 7.82 & 80.95 & 14.50 & 3.79 & 0.11 & 0.12 & 0.38 & 5.20 & 14.99 & 9.01 & 37.70 & 21.40 & 10.60 & 6.40 \\
\hline $33-40$ & $\mathrm{~A} 3$ & $\mathrm{~T} 14$ & $31 \mathrm{RD} 128$ & 42.45 & 24.89 & 17.56 & 58.56 & 30.99 & 8.29 & 0.03 & 0.15 & 0.30 & 2.18 & 10.95 & 11.06 & 37.90 & 20.20 & 10.70 & 6.00 \\
\hline $45-50$ & $\mathrm{~A} 3$ & T14 & $31 \mathrm{RD} 128$ & 41.91 & 33.79 & 8.12 & 80.63 & 15.30 & 3.33 & 0.00 & 0.07 & 0.20 & 2.19 & 10.83 & 11.24 & 37.20 & 23.30 & 11.50 & 7.00 \\
\hline $65-70$ & $\mathrm{~A} 3$ & $\mathrm{T14}$ & 31RD128 & 47.74 & 30.86 & 16.88 & 64.56 & 28.81 & 6.63 & 0.04 & 0.09 & 0.17 & 2.54 & 14.58 & 13.58 & 42.60 & 22.30 & 10.30 & 6.10 \\
\hline $85-90$ & $\mathrm{~A} 3$ & $\mathrm{~T} 14$ & 31RD128 & 41.74 & 33.79 & 7.95 & 80.96 & 16.49 & 0.00 & 0.00 & 0.02 & 0.05 & 2.71 & 16.94 & 11.92 & 48.60 & 21.10 & 10.10 & 6.80 \\
\hline \begin{tabular}{|l|}
$100-105$ \\
\end{tabular} & $\mathrm{~A} 3$ & T14 & 31RD128 & 33.95 & 23.51 & 10.44 & 69.25 & 20.64 & 10.15 & 0.00 & 0.05 & 0.06 & 1.79 & 12.53 & 9.04 & 37.40 & 15.50 & 8.00 & 6.20 \\
\hline $0-2$ & $\mathrm{~A} 3$ & $\mathrm{~T} 16$ & $\mathrm{~N} / \mathrm{A}$ & 27.24 & 22.35 & 4.89 & 81.75 & & & 0.08 & 0.21 & 0.39 & 5.67 & 12.79 & 3.35 & & & & \\
\hline $10-15$ & $\mathrm{~A} 3$ & T16 & $\mathrm{N} / \mathrm{A}$ & 33.06 & 16.81 & 16.25 & 50.23 & 35.68 & 14.08 & 0.20 & 0.39 & 0.72 & 2.96 & 7.98 & 5.10 & 39.00 & 16.40 & 9.30 & 7.00 \\
\hline $20-25$ & $\mathrm{~A} 3$ & T16 & $\mathrm{N} / \mathrm{A}$ & 38.22 & 33.79 & 4.43 & 88.04 & 7.71 & 4.25 & 0.14 & 0.31 & 0.45 & 8.03 & 19.06 & 4.66 & 28.90 & 16.80 & 10.40 & 8.40 \\
\hline $30-35$ & $\mathrm{~A} 3$ & T16 & $\mathrm{N} / \mathrm{A}$ & 34.84 & 29.68 & 5.16 & 85.13 & 9.76 & 5.13 & 0.02 & 0.12 & 0.37 & 7.33 & 17.31 & 4.41 & 29.90 & 17.40 & 9.90 & 8.40 \\
\hline $40-45$ & $\mathrm{~A} 3$ & T16 & $\mathrm{N} / \mathrm{A}$ & 40.48 & 34.88 & 5.60 & 86.17 & 9.47 & 4.37 & 0.00 & 0.10 & 0.33 & 4.28 & 21.75 & 8.33 & 38.40 & 15.40 & 8.20 & 6.50 \\
\hline $50-55$ & $\mathrm{~A} 3$ & $T 16$ & $\mathrm{~N} / \mathrm{A}$ & 47.83 & 38.73 & 9.10 & 80.98 & 13.89 & 6.16 & 0.00 & 0.03 & 0.10 & 3.19 & 22.84 & 12.61 & 40.40 & 16.90 & 9.10 & 6.60 \\
\hline $60-65$ & $\mathrm{~A} 3$ & $T 16$ & $\mathrm{~N} / \mathrm{A}$ & 40.76 & 36.66 & 4.10 & 89.94 & 7.09 & 2.96 & 0.00 & 0.02 & 0.16 & 7.20 & 22.82 & 6.49 & 39.40 & 15.00 & 9.50 & 6.60 \\
\hline $70-75$ & $\mathrm{~A} 3$ & $\mathrm{~T} 16$ & $\mathrm{~N} / \mathrm{A}$ & 44.85 & 42.63 & 2.22 & 95.06 & 2.96 & 1.98 & 0.00 & 0.01 & 0.06 & 7.95 & 30.14 & 4.43 & 30.70 & 14.30 & 7.10 & 7.80 \\
\hline $82-87$ & $\mathrm{~A} 3$ & T16 & $\mathrm{N} / \mathrm{A}$ & 42.74 & 16.22 & 26.52 & 37.88 & 47.83 & 14.29 & 0.03 & 0.08 & 0.11 & 0.58 & 4.81 & 10.56 & 35.40 & 23.50 & 11.70 & 6.40 \\
\hline $93-98$ & A3 & T16 & $\mathrm{N} / \mathrm{A}$ & 42.88 & 17.37 & 25.51 & 40.41 & 45.47 & 14.12 & 0.04 & 0.10 & 0.15 & 0.54 & 5.40 & 11.01 & 35.90 & 21.90 & 11.40 & 7.10 \\
\hline \begin{tabular}{|l|}
$100-105$ \\
\end{tabular} & $\mathrm{~A} 3$ & T16 & $\mathrm{N} / \mathrm{A}$ & 46.35 & 17.78 & 28.57 & 38.25 & 47.86 & 13.96 & 0.05 & 0.25 & 0.48 & 0.83 & 4.72 & 11.37 & 36.00 & 23.20 & 11.60 & 6.70 \\
\hline \begin{tabular}{|l|}
$110-115$ \\
\end{tabular} & $\mathrm{~A} 3$ & $T 16$ & $\mathrm{~N} / \mathrm{A}$ & 41.63 & 16.73 & 24.90 & 40.04 & 46.77 & 13.25 & 0.06 & 0.42 & 0.59 & 0.85 & 4.39 & 10.32 & 36.60 & 23.10 & 11.50 & 6.80 \\
\hline \begin{tabular}{|l|}
$120-125$ \\
\end{tabular} & A3 & T16 & $\mathrm{N} / \mathrm{A}$ & 45.11 & 19.42 & 25.69 & 42.34 & 44.68 & 12.91 & 0.32 & 0.93 & 0.75 & 0.87 & 5.25 & 11.34 & 35.90 & 23.50 & 11.50 & 6.60 \\
\hline \begin{tabular}{|c|}
$10-15$ \\
\end{tabular} & $\mathrm{~A} 8$ & $\mathrm{T2}$ & \begin{tabular}{|l|}
$31 \mathrm{RD} 1173$ \\
\end{tabular} & 36.20 & 14.1345 & 22.06 & 38.08 & 34.24 & 24.77 & 0.35 & 0.58 & 0.97 & 3.99 & 4.78 & 3.47 & 18.50 & 18.30 & 11.70 & 6.80 \\
\hline $20-25$ & $\mathrm{~A} 8$ & $\mathrm{~T} 2$ & \begin{tabular}{|l|} 
31RD1173 \\
\end{tabular} & 53.36 & 23.7289 & 29.63 & 41.87 & 33.02 & 21.68 & 1.39 & 0.98 & 1.18 & 3.64 & 8.58 & 7.96 & 22.30 & 16.40 & 10.60 & 7.50 \\
\hline $30-35$ & A8 & $\mathrm{T} 2$ & \begin{tabular}{|l|}
$31 \mathrm{RD} 1173$ \\
\end{tabular} & 60.21 & 50.6009 & 9.61 & 83.98 & 7.75 & 6.12 & 0.03 & 0.12 & 1.22 & 19.87 & 25.11 & 4.25 & 17.80 & 13.10 & 9.70 & 7.80 \\
\hline $40-45$ & A8 & $\mathrm{T} 2$ & \begin{tabular}{|l|}
31 RD1173 \\
\end{tabular} & 54.93 & 39.7775 & 15.15 & 72.30 & 17.73 & 8.06 & 0.07 & 0.50 & 1.26 & 9.19 & 22.25 & 6.51 & 23.60 & 17.50 & 13.60 & 9.30 \\
\hline $50-55$ & A8 & $\mathrm{T} 2$ & \begin{tabular}{|c|}
$31 \mathrm{RD} 1173$ \\
\end{tabular} & 48.21 & 22.5459 & 25.67 & 46.52 & 39.04 & 11.55 & 0.12 & 0.42 & 1.40 & 5.67 & 8.13 & 6.80 & 24.10 & 24.20 & 15.50 & 9.20 \\
\hline $60-65$ & $\mathrm{~A} 8$ & $\mathrm{~T} 2$ & \begin{tabular}{|l} 
31RD1173 \\
\end{tabular} & 58.22 & 29.1352 & 29.08 & 49.70 & 34.96 & 12.22 & 0.20 & 0.65 & 1.60 & 7.84 & 10.76 & 8.09 & 24.20 & 23.60 & 13.70 & 8.00 \\
\hline $70-75$ & $\mathrm{~A} 8$ & $\mathrm{~T} 2$ & \begin{tabular}{|l|l|}
$31 \mathrm{RD} 1173$ \\
\end{tabular} & 45.44 & 23.0654 & 22.37 & 50.38 & 29.13 & 18.56 & 0.17 & 0.32 & 1.21 & 6.63 & 8.92 & 5.82 & 21.20 & 19.30 & 11.30 & 6.90 \\
\hline $80-85$ & $\mathrm{~A} 8$ & $\mathrm{~T} 2$ & \begin{tabular}{|c|}
$31 \mathrm{RD} 1173$ \\
\end{tabular} & 53.88 & 28.8989 & 24.98 & 53.35 & 20.62 & 23.70 & 0.16 & 0.43 & 1.36 & 8.97 & 11.63 & 6.35 & 16.60 & 13.60 & 8.30 & 5.70 \\
\hline $90-95$ & A8 & T2 & \begin{tabular}{|l|}
$31 \mathrm{RD} 1173$ \\
\end{tabular} & 48.35 & 26.7530 & 21.60 & 55.14 & 15.07 & 27.45 & 0.09 & 0.23 & 1.50 & 8.61 & 10.99 & 5.33 & 12.00 & 10.50 & 6.50 & 4.60 \\
\hline \begin{tabular}{|l|}
$100-105$ \\
\end{tabular} & A8 & $\mathrm{T} 2$ & \begin{tabular}{|l|} 
31RD1173 \\
\end{tabular} & 67.57 & 40.7834 & 26.79 & 60.31 & 13.41 & 24.61 & 0.03 & 0.33 & 2.93 & 14.29 & 15.94 & 7.27 & 12.50 & 10.60 & 6.10 & 4.60 \\
\hline \begin{tabular}{|l|}
$110-115$ \\
\end{tabular} & $\mathrm{~A} 8$ & $\mathrm{~T} 2$ & \begin{tabular}{|l|} 
31RD1173 \\
\end{tabular} & 70.54 & 44.0843 & 26.45 & 62.38 & 12.45 & 23.51 & 0.08 & 0.29 & 3.43 & 15.73 & 16.89 & 7.66 & 13.00 & 9.90 & 5.70 & 4.50 \\
\hline $0-5$ & A9 & T5 & 31RD376 & 27.37 & 14.66 & 12.71 & 53.56 & & & 0.00 & 0.03 & 0.14 & 1.82 & 6.88 & 5.57 & & & & \\
\hline 10 & A9 & T5 & 31RD376 & 23.01 & 11.12 & 11.89 & 48.32 & 33.23 & 18.40 & 0.00 & 0.06 & 0.20 & 1.58 & 5.10 & 4.38 & 24.30 & 18.10 & 13.50 & 8.40 \\
\hline 20 & A9 & T5 & 31RD376 & 22.80 & 16.38 & 6.42 & 71.83 & 19.75 & 8.51 & 0.00 & 0.00 & 0.04 & 2.27 & 8.64 & 5.40 & 38.50 & 16.50 & 9.60 & 5.50 \\
\hline 30 & $\mathrm{~A} 9$ & T5 & 31RD376 & 50.01 & 35.90 & 14.11 & 71.76 & 22.00 & 6.24 & 0.01 & 0.02 & 0.08 & 4.78 & 18.59 & 12.24 & 40.40 & 21.50 & 10.40 & 5.60 \\
\hline 40 & A9 & T5 & 31RD376 & 31.08 & 21.73 & 9.35 & 69.92 & 22.68 & 7.40 & 0.00 & 0.00 & 0.15 & 3.07 & 11.26 & 7.57 & 40.40 & 19.00 & 10.00 & 6.00 \\
\hline 50 & A9 & T5 & 31RD376 & 23.90 & 16.82 & 7.08 & 70.38 & 21.68 & 7.97 & 0.00 & 0.02 & 0.13 & 2.65 & 8.71 & 5.62 & 35.50 & 20.10 & 11.10 & 6.50 \\
\hline 60 & A9 & T5 & 31RD376 & 41.68 & 28.79 & 12.89 & 69.08 & 24.24 & 6.68 & 0.00 & 0.01 & 0.08 & 4.00 & 14.78 & 9.87 & 41.30 & 20.20 & 10.50 & 6.40 \\
\hline 70 & A9 & T5 & 31RD376 & 24.15 & 16.39 & 7.76 & 67.86 & 23.85 & 8.29 & 0.00 & 0.05 & 0.05 & 2.27 & 8.34 & 5.73 & 35.40 & 20.40 & 11.30 & 7.10 \\
\hline 80 & $\mathrm{~A} 9$ & T5 & 31RD376 & 27.20 & 16.51 & 10.69 & 60.70 & 24.84 & 14.46 & 0.00 & 0.03 & 0.06 & 2.08 & 8.23 & 6.14 & 29.20 & 17.70 & 9.90 & 6.40 \\
\hline 90 & A9 & T5 & 31RD376 & \begin{tabular}{|l|}
21.65 \\
\end{tabular} & 11.70 & 9.95 & 52.88 & 29.21 & 16.68 & 0.25 & 0.05 & 0.09 & 1.13 & 5.41 & 4.70 & 29.20 & 16.80 & 9.80 & 6.20 \\
\hline 100 & A9 & T5 & 31 RD376 & 18.01 & 8.56 & 9.45 & 47.37 & 30.42 & 22.21 & 0.03 & 0.03 & 0.03 & 0.79 & 3.85 & 3.88 & 25.20 & 16.90 & 9.60 & 6.10 \\
\hline $0-5$ & $\mathrm{~A} 9$ & T6 & 31RD283 & 17.17 & 7.05 & 10.12 & 40.65 & & & 0.07 & 0.30 & 0.48 & 1.11 & 2.38 & 2.54 & & & & \\
\hline
\end{tabular}




\begin{tabular}{|c|c|c|c|c|c|c|c|c|c|c|c|c|c|c|c|c|c|c|c|}
\hline \multicolumn{2}{|c|}{ Historic sediment } & \multicolumn{2}{|c|}{ Prehistoric sediment } & & & & & & & \multirow[b]{2}{*}{ Weight } & \multirow[b]{2}{*}{ Weight } & \multirow[b]{2}{*}{ Weight } & \multirow[b]{2}{*}{ Weight } & \multirow[b]{2}{*}{ Weight } & \multirow[b]{2}{*}{ Weight } & \multirow[b]{2}{*}{ Weight } & \multirow[b]{2}{*}{ Weight } & \multirow[b]{2}{*}{ Weight } & \multirow[b]{2}{*}{ Weight } \\
\hline & & & & & & & $\begin{array}{c}\text { Percent } \\
\text { Sand }\end{array}$ & \begin{tabular}{|c|}
$\begin{array}{c}\text { Percent } \\
\text { Silt }\end{array}$ \\
\end{tabular} & \begin{tabular}{|c|} 
Percent \\
Clay
\end{tabular} & & & & & & & & & & \\
\hline Depth & $\begin{array}{c}\text { Area } \\
\text { Location }\end{array}$ & \begin{tabular}{|c|} 
Trench \\
Number
\end{tabular} & Site Number & $\begin{array}{c}\text { Sample } \\
\text { Wt. }\end{array}$ & $\begin{array}{c}\text { Coarse } \\
\text { Wt. }\end{array}$ & Fine Wt. & $\begin{array}{c}<-1.0 \text { to } 4.0 \\
\text { phi }\end{array}$ & \begin{tabular}{|c|}
$<4.0-8.0$ \\
phi
\end{tabular} & $\begin{array}{c}<8.0-<9 \\
\text { phi }\end{array}$ & $\begin{array}{c}-1.0 \text { phi and } \\
\text { greater }\end{array}$ & $\begin{array}{c}<-1.0-0.0 \\
\text { phi }\end{array}$ & $\begin{array}{c}<0-1.0 \\
\text { phi }\end{array}$ & $\begin{array}{c}<1.0-2.0 \\
\text { phi }\end{array}$ & $\begin{array}{c}<2.0-3.0 \\
\text { phi }\end{array}$ & $\begin{array}{c}<3.0-4.0 \\
\text { phi }\end{array}$ & $\begin{array}{c}<4.0-5.0 \\
\text { phi }\end{array}$ & $\begin{array}{c}<5.0-6.0 \\
\text { phi }\end{array}$ & \begin{tabular}{|c|}
$<6.0-7.0$ \\
phi
\end{tabular} & $\begin{array}{c}<7.0-8.0 \\
\text { phi }\end{array}$ \\
\hline 15 & A9 & T6 & 31RD283 & 22.77 & 12.74 & 10.03 & 54.29 & 27.88 & 17.83 & 0.38 & 0.26 & 0.73 & 2.85 & 5.04 & 3.19 & 20.80 & 17.50 & 13.30 & 9.40 \\
\hline$\frac{15}{25}$ & A9 & T6 & 31 RD283 & 28.70 & 15.76 & 12.94 & 53.07 & & & 0.53 & 0.44 & 0.76 & 3.52 & $\frac{0.07}{6.32}$ & 4.07 & & & & \\
\hline 35 & A9 & T6 & 31RD283 & 12.44 & 7.47 & 4.97 & 59.35 & 23.42 & 17.24 & 0.09 & 0.07 & 0.18 & 1.68 & 3.38 & 1.89 & 17.80 & 17.30 & 12.90 & 9.60 \\
\hline 45 & A9 & T6 & 31RD283 & 27.11 & 15.97 & 11.14 & 56.99 & & & 0.52 & 0.36 & 0.62 & 3.62 & 6.72 & 4.22 & & & & \\
\hline 55 & A9 & T6 & $31 \mathrm{RD} 283$ & 23.43 & 15.72 & 7.71 & 67.09 & 21.55 & 11.35 & 0.00 & 0.12 & 0.65 & 6.18 & 5.78 & 2.79 & 25.50 & 18.90 & 12.60 & 8.50 \\
\hline $61-63$ & A9 & T6 & 31RD283 & 31.55 & 23.97 & 7.58 & 75.84 & 15.51 & 8.65 & 0.04 & 0.28 & 1.51 & 10.65 & 8.24 & 3.13 & 22.70 & 18.50 & 13.80 & 9.20 \\
\hline $68-72$ & $\mathrm{~A} 9$ & T6 & 31RD283 & 17.85 & 11.31 & 6.54 & 63.31 & 23.56 & 13.17 & 0.01 & 0.13 & 0.36 & 2.87 & 5.12 & 2.69 & 22.80 & 18.70 & 12.80 & 9.90 \\
\hline $75-77$ & A9 & T6 & 31 RD283 & 26.40 & 17.66 & 8.74 & 66.18 & & & 0.19 & 0.16 & 0.46 & 4.40 & 8.07 & 4.21 & & & & \\
\hline $82-84$ & A9 & T6 & 31RD283 & 27.11 & 17.44 & 9.67 & 64.32 & 25.12 & 10.60 & 0.00 & 0.06 & 0.43 & 3.98 & 8.21 & 4.65 & 27.30 & 20.00 & 13.70 & 9.40 \\
\hline $87-89$ & A9 & T6 & 31RD283 & 21.71 & 13.46 & 8.25 & 61.99 & & & 0.00 & 0.06 & 0.32 & 3.05 & 6.26 & 3.69 & & & & \\
\hline 95 & A9 & T6 & 31RD283 & 20.62 & 12.27 & 8.35 & 59.49 & 27.75 & 12.76 & 0.00 & 0.04 & 0.33 & 2.60 & 5.69 & 3.57 & 24.20 & 19.00 & 14.70 & 10.60 \\
\hline $0-5$ & $\overline{A 9}$ & $\mathrm{~T} 12$ & 31RD282 & 20.93 & 3.16 & 0.86 & 14.43 & & & 0.14 & 0.13 & 0.30 & 0.49 & 0.78 & 1.24 & & & & \\
\hline 15 & A9 & $\mathrm{T} 12$ & 31RD282 & 18.68 & 1.63 & 3.12 & 8.73 & & & 0.00 & 0.01 & 0.06 & 0.05 & 0.13 & 1.42 & & & & \\
\hline 25 & A9 & T12 & 31 RD282 & 19.52 & 1.22 & 1.52 & 6.25 & & & 0.00 & 0.02 & 0.04 & 0.05 & 0.11 & 1.02 & & & & \\
\hline 35 & A9 & T12 & 31 RD282 & 22.27 & 0.70 & 0.26 & 3.14 & & & 0.00 & 0.01 & 0.02 & 0.07 & 0.11 & 0.49 & & & & \\
\hline 45 & A9 & T12 & 31 RD282 & 25.42 & 2.89 & 2.6 & 11.25 & & & 0.03 & 0.02 & 0.04 & 0.08 & 0.15 & 2.40 & & & & \\
\hline $55-59$ & A9 & T12 & 31RD282 & 19.47 & 11.33 & 1.1 & 53.37 & & & 0.94 & 0.96 & 1.17 & 2.43 & 3.14 & 2.36 & & & & \\
\hline 65 & A9 & $\mathrm{T} 12$ & 31RD282 & 30.02 & 16.35 & 1.92 & 53.72 & & & 0.22 & 0.80 & 1.38 & 4.48 & 5.57 & 3.94 & & & & \\
\hline 75 & A9 & $\mathrm{T} 12$ & 31RD282 & 34.03 & 20.50 & 2.1 & 58.54 & & & 0.58 & 1.26 & 2.02 & 4.82 & 6.92 & 4.71 & & & & \\
\hline 85 & A9 & T12 & 31RD282 & 22.86 & 12.42 & 1.38 & 53.76 & & & 0.13 & 0.63 & 1.33 & 2.44 & 4.41 & 3.55 & & & & \\
\hline 95 & A9 & T12 & 31 RD282 & 31.89 & 16.46 & 1.79 & 50.11 & & & 0.48 & 0.92 & 1.66 & 3.10 & 5.65 & 4.59 & & & & \\
\hline 105 & A9 & $\mathrm{T} 12$ & 31RD282 & 28.63 & 14.39 & 1.5 & 48.52 & & & 0.50 & 0.90 & 1.47 & 2.60 & 4.92 & 4.03 & & & & \\
\hline 115 & $\overline{A 9}$ & T12 & 31RD282 & 21.45 & 10.32 & 1.09 & 47.46 & & & 0.14 & 0.58 & 0.94 & 1.91 & 3.73 & 2.93 & & & & \\
\hline & & & & & & & & & & & & & & & & & & & \\
\hline
\end{tabular}




\begin{tabular}{|c|c|c|c|c|c|c|c|c|c|c|c|c|c|c|c|c|c|}
\hline \multicolumn{2}{|c|}{ Historic sediment } & \multicolumn{2}{|c|}{ Prehistoric sediment } & \multirow[b]{2}{*}{ Weight } & \multirow[b]{2}{*}{ Weight } & \multirow[b]{2}{*}{$\begin{array}{l}\text { Percent } \\
\text { Whole }\end{array}$} & \multirow[b]{2}{*}{$\begin{array}{l}\text { Percent } \\
\text { Whole }\end{array}$} & \multirow[b]{2}{*}{$\begin{array}{l}\text { Percent } \\
\text { Whole }\end{array}$} & \multirow[b]{2}{*}{$\begin{array}{l}\text { Percent } \\
\text { Whole }\end{array}$} & \multirow[b]{2}{*}{\begin{tabular}{|l|} 
Percent \\
Whole
\end{tabular}} & \multirow[b]{2}{*}{$\begin{array}{l}\text { Percent } \\
\text { Whole }\end{array}$} & \multirow[b]{2}{*}{\begin{tabular}{|l|} 
Percent \\
Whole
\end{tabular}} & \multirow[b]{2}{*}{\begin{tabular}{|c|} 
Percent \\
Whole
\end{tabular}} & \multirow[b]{2}{*}{$\begin{array}{l}\text { Percent } \\
\text { Whole }\end{array}$} & \multirow[b]{2}{*}{$\begin{array}{l}\text { Percent } \\
\text { Whole }\end{array}$} & \multirow[b]{2}{*}{$\begin{array}{l}\text { Percent } \\
\text { Whole }\end{array}$} & \multirow[b]{2}{*}{$\begin{array}{l}\begin{array}{c}\text { Percent } \\
\text { Whole }\end{array} \\
\end{array}$} \\
\hline & & & & & & & & & & & & & & & & & \\
\hline Depth & $\begin{array}{c}\text { Area } \\
\text { Location }\end{array}$ & \begin{tabular}{|c|} 
Trench \\
Number
\end{tabular} & Site Number & \begin{tabular}{|c|}
$<8.0-9.0$ \\
$\mathrm{phi}$
\end{tabular} & $\begin{array}{l}<9 \text { phi } \\
\text { (finer } \\
\text { than) }\end{array}$ & $\begin{array}{l}-1.0 \mathrm{phi} \\
\text { and } \\
\text { greater }\end{array}$ & $\begin{array}{c}<-1.0-0.0 \\
\text { phi }\end{array}$ & $\begin{array}{c}<0-1.0 \\
\text { phi }\end{array}$ & $\begin{array}{c}<1.0-2.0 \\
\text { phi }\end{array}$ & $\begin{array}{c}<2.0-3.0 \\
\text { phi }\end{array}$ & $\begin{array}{c}<3.0-4.0 \\
\text { phi }\end{array}$ & \begin{tabular}{|c|}
$<4.0-5.0$ \\
$\mathrm{phi}$
\end{tabular} & $\begin{array}{c}<5.0-6.0 \\
\mathrm{phi}\end{array}$ & $\begin{array}{c}<6.0-7.0 \\
\text { phi }\end{array}$ & $\begin{array}{c}<7.0-8.0 \\
\text { phi }\end{array}$ & \begin{tabular}{|c|}
$<8.0-9.0$ \\
phi
\end{tabular} & \begin{tabular}{|c|}
$<<9$ phi \\
(finer than)
\end{tabular} \\
\hline $0-5$ & A2 & $\mathrm{T} 1$ & \begin{tabular}{|c|}
31 RD1163 \\
\end{tabular} & & & 0.16 & 0.08 & 0.28 & 1.85 & 10.89 & 19.29 & & & & & & \\
\hline 10 & $\mathrm{~A} 2$ & $\mathrm{~T} 1$ & \begin{tabular}{|c|}
$31 \mathrm{RD} 1163$ \\
\end{tabular} & 5.60 & 28.60 & 0.00 & 0.10 & 0.42 & 2.63 & 14.16 & 19.10 & 15.86 & 13.74 & 7.70 & 5.01 & 3.60 & 18.36 \\
\hline 20 & $\mathrm{~A} 2$ & $\mathrm{~T} 1$ & \begin{tabular}{|l|}
31 RD1163 \\
\end{tabular} & 5.50 & 26.50 & 0.00 & 0.06 & 0.37 & 4.15 & 17.58 & 20.04 & 15.81 & 12.64 & 6.75 & 4.10 & 3.17 & 15.29 \\
\hline 30 & A2 & $\mathrm{T} 1$ & 31 RD1163 & 4.50 & 24.70 & 0.00 & 0.19 & 0.51 & 5.11 & 18.59 & 19.65 & 17.10 & 12.66 & 6.41 & 3.66 & 2.53 & 13.89 \\
\hline 40 & A2 & $\mathrm{T} 1$ & \begin{tabular}{|c|}
31 RD1163 \\
\end{tabular} & 4.60 & 24.80 & 0.03 & 0.06 & 0.18 & 3.29 & 17.91 & 20.87 & 17.86 & 12.90 & 5.93 & 3.92 & 2.65 & 14.29 \\
\hline 50 & A2 & $\mathrm{T} 1$ & \begin{tabular}{|c|}
31 RD1163 \\
\end{tabular} & 4.80 & 24.70 & 0.00 & 0.06 & 0.17 & 2.66 & 16.64 & 19.84 & 16.68 & 14.21 & 7.40 & 4.15 & 2.89 & 14.87 \\
\hline 60 & $\mathrm{~A} 2$ & $\mathrm{~T} 1$ & 31RD1163 & 4.90 & 24.10 & 0.00 & 0.12 & 0.12 & 2.69 & 18.37 & 20.58 & 17.30 & 13.12 & 6.91 & 3.89 & 2.84 & 13.99 \\
\hline 70 & $\mathrm{~A} 2$ & $\mathrm{~T} 1$ & \begin{tabular}{|l|}
$31 \mathrm{RD} 1163$ \\
\end{tabular} & 5.70 & 25.30 & 0.00 & 0.00 & 0.11 & 5.79 & 29.32 & 22.60 & 13.25 & 8.85 & 4.19 & 2.68 & 2.39 & 10.61 \\
\hline 80 & $\mathrm{~A} 2$ & $\overline{T 1}$ & 31RD1163 & 5.10 & 27.20 & 0.00 & 0.15 & 0.12 & 3.52 & 21.65 & 23.07 & 15.23 & 10.65 & 5.71 & 3.24 & 2.62 & 14.00 \\
\hline 90 & A2 & $\mathrm{T} 1$ & \begin{tabular}{|c|}
31 RD1163 \\
\end{tabular} & & & 0.00 & 0.04 & 0.20 & 3.06 & 21.77 & 25.62 & & & & & & \\
\hline 100 & $\bar{A} 2$ & $\overline{T 1}$ & 31RD1163 & 4.50 & 27.20 & 0.00 & 0.14 & 0.17 & 2.37 & 18.29 & 25.34 & 17.14 & 11.21 & 5.29 & 2.83 & 2.40 & 14.52 \\
\hline 110 & A2 & $\mathrm{T} 1$ & \begin{tabular}{|c|}
$31 \mathrm{RD} 1163$ \\
\end{tabular} & 4.50 & 27.30 & 0.00 & 0.07 & 0.14 & 2.52 & 20.53 & 25.17 & 16.51 & 10.56 & 5.17 & 3.00 & 2.33 & 14.13 \\
\hline 120 & $\mathrm{~A} 2$ & $\mathrm{~T} 1$ & \begin{tabular}{|c|}
$31 \mathrm{RD} 1163$ \\
\end{tabular} & 4.10 & 23.60 & 0.00 & 0.00 & 0.07 & 3.28 & 24.79 & 27.11 & 16.36 & 9.30 & 4.34 & 2.32 & 1.83 & 10.55 \\
\hline 130 & $\mathrm{~A} 2$ & $\mathrm{~T} 1$ & \begin{tabular}{|c|}
31 RD1163 \\
\end{tabular} & & & 0.00 & 0.16 & 0.04 & 5.01 & 29.89 & 27.25 & 13.89 & 7.19 & 2.02 & & & \\
\hline 140 & $\mathrm{~A} 2$ & $\mathrm{~T} 1$ & \begin{tabular}{|c|}
$31 \mathrm{RD} 1163$ \\
\end{tabular} & 4.00 & 24.20 & 0.00 & 0.03 & 0.16 & 9.96 & 35.47 & 23.74 & 11.57 & 5.94 & 2.63 & 1.61 & 1.21 & 7.33 \\
\hline 150 & $\mathrm{~A} 2$ & $\mathrm{~T} 1$ & \begin{tabular}{|c|}
31 RD1163 \\
\end{tabular} & & & 0.00 & 0.00 & 0.16 & 10.08 & 33.13 & 22.30 & & & & & & \\
\hline $0-5$ & $\bar{A} 2$ & $\mathrm{T7}$ & \begin{tabular}{|l|} 
31RD1164 \\
\end{tabular} & & & 0.52 & 0.97 & 4.51 & 16.55 & 20.01 & 16.40 & & & & & & \\
\hline 10 & A2 & $\mathrm{T7}$ & \begin{tabular}{|c|} 
31RD1164 \\
\end{tabular} & 4.20 & 22.50 & 0.58 & 0.99 & 3.47 & 14.74 & 20.43 & 18.25 & 14.72 & 9.42 & 4.58 & 2.42 & 1.78 & 9.54 \\
\hline 20 & A2 & $\mathrm{T7}$ & \begin{tabular}{|c|}
$31 \mathrm{RD} 1164$ \\
\end{tabular} & 4.20 & 24.20 & 0.15 & 0.71 & 3.61 & 14.72 & 21.19 & 18.44 & 13.50 & 9.33 & 4.34 & 2.09 & 1.72 & 9.90 \\
\hline 30 & $\mathrm{~A} 2$ & T7 & \begin{tabular}{|c|} 
31RD1164 \\
\end{tabular} & 4.00 & 21.60 & 0.52 & 0.72 & 3.87 & 15.18 & 22.19 & 19.42 & 13.98 & 8.84 & 3.79 & 1.88 & 1.53 & 8.27 \\
\hline 40 & $\mathrm{~A} 2$ & $\mathrm{~T} 7$ & \begin{tabular}{|c|}
$31 \mathrm{RD} 1164$ \\
\end{tabular} & 3.60 & 21.10 & 0.15 & 0.95 & 5.24 & 21.13 & 30.44 & 26.22 & 5.78 & 3.59 & 1.56 & 0.68 & 0.56 & 3.25 \\
\hline 50 & $\mathrm{~A}_{2}$ & $T 7$ & \begin{tabular}{|c|}
31 RD1164 \\
\end{tabular} & 5.00 & 22.70 & 0.27 & 0.57 & 3.88 & 17.46 & 20.51 & 17.04 & 12.36 & 9.22 & 5.07 & 2.42 & 2.01 & 9.14 \\
\hline 60 & A2 & T7 & \begin{tabular}{|c|} 
31RD1164 \\
\end{tabular} & 4.50 & 21.30 & 0.12 & 0.47 & 4.27 & 23.91 & 22.25 & 14.24 & 11.67 & 7.91 & 3.87 & 1.92 & 1.54 & 7.29 \\
\hline 70 & A2 & $\mathrm{T7}$ & \begin{tabular}{|c|}
31 RD1164 \\
\end{tabular} & 5.10 & 22.30 & 0.07 & 0.50 & 4.05 & 17.09 & 19.44 & 16.83 & 12.59 & 9.53 & 5.39 & 2.84 & 2.13 & 9.32 \\
\hline 80 & A2 & $T 7$ & \begin{tabular}{|c|}
$31 \mathrm{RD} 1164$ \\
\end{tabular} & 4.40 & 18.60 & 0.23 & 0.56 & 2.93 & 10.35 & 17.83 & 19.72 & 17.16 & 11.36 & 5.90 & 3.07 & 2.14 & 9.07 \\
\hline 90 & $\mathrm{~A} 2$ & $\mathrm{T7}$ & \begin{tabular}{|l|}
31 RD1164 \\
\end{tabular} & 4.20 & 22.30 & 0.05 & 0.54 & 3.06 & 9.13 & 16.68 & 18.97 & 15.88 & 11.68 & 6.51 & 3.53 & 2.15 & 11.42 \\
\hline 100 & $\mathrm{~A} 2$ & $\mathrm{T7}$ & \begin{tabular}{|l|}
$31 R D 1164$ \\
\end{tabular} & 5.10 & 25.60 & 3.95 & 0.89 & 3.38 & 9.44 & 15.25 & 17.45 & 14.34 & 12.31 & 6.85 & 3.58 & 2.73 & 13.70 \\
\hline 110 & A2 & $\mathrm{T7}$ & \begin{tabular}{|l|}
31 RD1164 \\
\end{tabular} & 5.30 & 24.30 & 2.67 & 1.58 & 4.37 & 9.27 & 15.33 & 17.47 & 13.89 & 11.67 & 7.02 & 3.72 & 2.74 & 12.55 \\
\hline 120 & A2 & T7 & \begin{tabular}{|c|} 
31RD1164 \\
\end{tabular} & 4.60 & 24.30 & 4.71 & 1.99 & 4.26 & 8.97 & 14.79 & 16.81 & 15.93 & 11.64 & 6.72 & 3.28 & 2.43 & 12.86 \\
\hline $10-15$ & $\bar{A} 3$ & T8 & \begin{tabular}{|l|} 
31RD1166 \\
\end{tabular} & & & 0.35 & 0.92 & 1.54 & 28.19 & 63.31 & 14.75 & & & & & & \\
\hline $20-25$ & $\mathrm{~A} 3$ & T8 & \begin{tabular}{|c|}
31 RD1166 \\
\end{tabular} & 4.50 & 19.80 & 0.23 & 1.02 & 1.96 & 10.57 & 31.30 & 20.16 & 12.49 & 7.22 & 3.97 & 2.19 & 1.54 & 6.78 \\
\hline $30-35$ & $\mathrm{~A} 3$ & T8 & \begin{tabular}{|c|}
31 RD1166 \\
\end{tabular} & 4.40 & 18.50 & 0.17 & 2.72 & 3.17 & 7.49 & 20.62 & 22.64 & 12.93 & 7.08 & 3.64 & 2.10 & 1.47 & 6.18 \\
\hline $40-45$ & A3 & T8 & \begin{tabular}{|c|}
$31 \mathrm{RD} 1166$ \\
\end{tabular} & 5.10 & 23.60 & 0.42 & 1.79 & 2.70 & 7.89 & 20.37 & 21.99 & 14.45 & 9.70 & 5.16 & 2.99 & 2.31 & 10.69 \\
\hline $50-55$ & $\mathrm{~A} 3$ & $\mathrm{~T} 8$ & \begin{tabular}{|l|}
31 RD1166 \\
\end{tabular} & 5.10 & 35.60 & 3.48 & 1.36 & 1.70 & 7.52 & 16.90 & 17.07 & 14.33 & 9.88 & 5.44 & 3.33 & 2.83 & 19.77 \\
\hline $60-65$ & $\mathrm{~A} 3$ & T8 & \begin{tabular}{|l|}
31 RD1166 \\
\end{tabular} & & & 2.19 & 1.10 & 1.51 & 8.07 & 16.93 & 16.12 & & & & & & \\
\hline $70-75$ & $\mathrm{~A} 3$ & T8 & \begin{tabular}{|c|} 
31RD1166 \\
\end{tabular} & 6.00 & 40.50 & 0.92 & 1.29 & 1.48 & 10.00 & 19.36 & 16.33 & 10.56 & 6.82 & 3.88 & 2.84 & 2.71 & 18.28 \\
\hline $80-85$ & A3 & T8 & \begin{tabular}{|c|}
31 RD1166 \\
\end{tabular} & 6.80 & 40.80 & 2.60 & 2.84 & 1.45 & 10.34 & 21.13 & 15.87 & 9.55 & 6.11 & 4.07 & 2.91 & 3.30 & 19.78 \\
\hline $85-90$ & A3 & T8 & \begin{tabular}{|c|}
$31 R D 1166$ \\
\end{tabular} & 5.20 & 59.10 & 12.50 & 23.98 & 3.86 & 5.59 & 11.73 & 9.35 & 6.50 & 4.41 & 3.04 & 2.32 & 2.36 & 26.86 \\
\hline $90-95$ & $\mathrm{~A} 3$ & $\mathrm{~T} 8$ & \begin{tabular}{|c|}
31 RD1166 \\
\end{tabular} & 5.10 & 58.60 & 1.69 & 3.23 & 1.50 & 11.29 & 21.90 & 15.03 & 6.98 & 4.50 & 3.05 & 2.44 & 2.39 & 27.46 \\
\hline \begin{tabular}{|l|}
$100-105$ \\
\end{tabular} & A3 & T8 & \begin{tabular}{|c|}
31 RD1166 \\
\end{tabular} & 4.90 & 58.00 & 0.29 & 0.48 & 1.56 & 13.89 & 25.74 & 16.04 & 6.39 & 4.44 & 2.67 & 2.24 & 2.07 & 24.55 \\
\hline $5-7$ & $\mathrm{~A} 3$ & $\mathrm{T13}$ & \begin{tabular}{|c|}
31 RD1166 \\
\end{tabular} & & & 0.00 & 0.37 & 4.12 & 43.16 & 32.80 & 6.49 & & & & & & \\
\hline $18-20$ & A3 & $\mathrm{T13}$ & \begin{tabular}{|c|}
$31 \mathrm{RD} 1166$ \\
\end{tabular} & & & 0.02 & 0.13 & 3.12 & 48.87 & 34.43 & 5.10 & & & & & & \\
\hline $34-36$ & $\mathrm{~A} 3$ & T13 & \begin{tabular}{|c|}
31 RD1166 \\
\end{tabular} & 6.20 & 32.90 & 0.00 & 0.12 & 1.10 & 34.49 & 50.09 & 7.68 & 1.86 & 1.00 & 0.65 & 0.46 & 0.40 & 2.14 \\
\hline $38-40$ & A3 & T13 & \begin{tabular}{|c|} 
31RD1166 \\
\end{tabular} & 4.40 & 14.40 & 0.00 & 0.38 & 0.95 & 5.60 & 28.35 & 28.60 & 14.40 & 7.79 & 3.59 & 2.19 & 1.58 & 5.17 \\
\hline $46-48$ & $\mathrm{~A} 3$ & $T 13$ & \begin{tabular}{|c|}
$31 \mathrm{RD} 1166$ \\
\end{tabular} & 4.60 & 9.70 & 0.16 & 0.54 & 1.00 & 5.87 & 29.22 & 28.60 & 15.16 & 7.19 & 3.60 & 2.05 & 1.62 & 3.42 \\
\hline 55-57 & $\mathrm{A} 3$ & $T 13$ & \begin{tabular}{|c|}
$31 \mathrm{RD} 1166$ \\
\end{tabular} & 3.80 & 15.80 & 0.23 & 0.58 & 1.43 & 6.21 & 28.10 & 27.17 & 16.05 & 7.27 & 3.43 & 2.32 & 1.40 & 5.83 \\
\hline
\end{tabular}




\begin{tabular}{|c|c|c|c|c|c|c|c|c|c|c|c|c|c|c|c|c|c|}
\hline \multicolumn{2}{|c|}{ Historic sediment } & \multicolumn{2}{|c|}{ Prehistoric sediment } & \multirow[b]{2}{*}{ Weight } & \multirow[b]{2}{*}{ Weight } & \multirow[b]{2}{*}{$\begin{array}{l}\text { Percent } \\
\text { Whole }\end{array}$} & \multirow[b]{2}{*}{\begin{tabular}{|l|}
$\begin{array}{c}\text { Percent } \\
\text { Whole }\end{array}$ \\
\end{tabular}} & \multirow[b]{2}{*}{$\begin{array}{l}\text { Percent } \\
\text { Whole }\end{array}$} & \multirow[b]{2}{*}{\begin{tabular}{|l} 
Percent \\
Whole
\end{tabular}} & \multirow[b]{2}{*}{$\begin{array}{l}\text { Percent } \\
\text { Whole }\end{array}$} & \multirow[b]{2}{*}{$\begin{array}{l}\text { Percent } \\
\text { Whole }\end{array}$} & \multirow[b]{2}{*}{\begin{tabular}{|l|} 
Percent \\
Whole
\end{tabular}} & \multirow[b]{2}{*}{\begin{tabular}{|l|} 
Percent \\
Whole
\end{tabular}} & \multirow[b]{2}{*}{\begin{tabular}{|l|} 
Percent \\
Whole
\end{tabular}} & \multirow[b]{2}{*}{\begin{tabular}{|c|} 
Percent \\
Whole
\end{tabular}} & \multirow[b]{2}{*}{\begin{tabular}{|l|} 
Percent \\
Whole
\end{tabular}} & \multirow[b]{2}{*}{$\begin{array}{l}\text { Percent } \\
\text { Whole }\end{array}$} \\
\hline & & & & & & & & & & & & & & & & & \\
\hline \begin{tabular}{|l|} 
Depth \\
\end{tabular} & $\begin{array}{c}\text { Area } \\
\text { Location }\end{array}$ & $\begin{array}{l}\text { Trench } \\
\text { Number }\end{array}$ & Site Number & $\begin{array}{c}<8.0-9.0 \\
\mathrm{phi}\end{array}$ & $\begin{array}{l}<9 \text { phi } \\
\text { (finer } \\
\text { than) }\end{array}$ & $\begin{array}{l}-1.0 \mathrm{phi} \\
\text { and } \\
\text { greater }\end{array}$ & $\begin{array}{c}<-1.0-0.0 \\
\text { phi }\end{array}$ & $\begin{array}{c}<0-1.0 \\
\text { phi }\end{array}$ & $\begin{array}{c}<1.0-2.0 \\
\text { phi }\end{array}$ & \begin{tabular}{|c|}
$<2.0-3.0$ \\
phi
\end{tabular} & $\begin{array}{c}<3.0-4.0 \\
\mathrm{phi}\end{array}$ & $\begin{array}{c}<4.0-5.0 \\
\text { phi }\end{array}$ & $\begin{array}{c}<5.0-6.0 \\
\mathrm{phi}\end{array}$ & $\begin{array}{c}<6.0-7.0 \\
\mathrm{phi}\end{array}$ & $\begin{array}{c}<7.0-8.0 \\
\mathrm{phi}\end{array}$ & $\begin{array}{c}<8.0-9.0 \\
\text { phi }\end{array}$ & \begin{tabular}{|c|}
$<9 \mathrm{phi}$ \\
(finer than)
\end{tabular} \\
\hline $70-75$ & $\mathrm{~A} 3$ & $\mathrm{~T} 13$ & 31RD1166 & 4.50 & 12.60 & 0.28 & 0.81 & 1.54 & 6.27 & 27.57 & 27.29 & 10.82 & 5.35 & 2.71 & 1.46 & 1.15 & 3.22 \\
\hline $85-90$ & $\mathrm{~A} 3$ & $T 13$ & 31RD1166 & 4.80 & 22.20 & 0.12 & 0.77 & 1.90 & 7.93 & 27.48 & 24.17 & 18.50 & 10.89 & 5.47 & 3.18 & 2.50 & 11.57 \\
\hline 105-110 & $\mathrm{A} 3$ & $\overline{T 13}$ & 31RD1166 & 5.10 & 34.90 & 3.86 & 0.94 & 1.88 & 7.88 & 20.17 & 18.39 & 13.82 & 8.76 & 4.81 & 3.04 & 2.58 & 17.67 \\
\hline 125-130 & A3 & $\mathrm{T} 13$ & 31RD1166 & 6.00 & 37.60 & 0.48 & 0.65 & 3.04 & 11.16 & 17.98 & 15.30 & 10.28 & 7.25 & 4.52 & 3.55 & 3.08 & 19.32 \\
\hline $20-25$ & A3 & T14 & 31RD128 & 4.70 & 15.20 & 0.26 & 0.28 & 0.91 & 12.49 & 36.02 & 21.65 & 7.18 & 4.08 & 2.02 & 1.22 & 0.90 & 2.90 \\
\hline $33-40$ & $\mathrm{~A} 3$ & T14 & 31 RD128 & 4.80 & 15.20 & 0.07 & 0.35 & 0.71 & 5.14 & 25.80 & 26.05 & 15.70 & 8.37 & 4.43 & 2.49 & 1.99 & 6.30 \\
\hline \begin{tabular}{|l|}
$45-50$ \\
\end{tabular} & A3 & T14 & $31 \mathrm{RD} 128$ & 4.70 & 12.50 & 0.00 & 0.17 & 0.48 & 5.23 & 25.85 & 26.83 & 7.20 & 4.51 & 2.23 & 1.36 & 0.91 & 2.42 \\
\hline $65-70$ & $\mathrm{~A} 3$ & T14 & 31RD128 & 4.60 & 14.10 & 0.08 & 0.19 & 0.36 & 5.32 & 30.54 & 28.45 & 15.10 & 7.90 & 3.65 & 2.16 & 1.63 & 5.00 \\
\hline $85-90$ & $\bar{A} 3$ & $\mathrm{T14}$ & $31 \mathrm{RD} 128$ & & & 0.00 & 0.06 & 0.13 & 6.49 & 40.59 & 28.57 & 9.26 & 4.02 & 1.92 & 1.29 & & \\
\hline \begin{tabular}{|c|}
$100-105$ \\
\end{tabular} & $\bar{A} 3$ & T14 & 31RD128 & 5.10 & 27.90 & 0.00 & 0.15 & 0.18 & 5.27 & 36.91 & 26.63 & 11.50 & 4.77 & 2.46 & 1.91 & 1.57 & 8.58 \\
\hline $0-2$ & A3 & T16 & $\mathrm{N} / \mathrm{A}$ & & & 0.29 & 0.77 & 1.43 & 20.81 & 46.95 & 12.30 & & & & & & \\
\hline $10-15$ & $\mathrm{~A} 3$ & T16 & $\mathrm{N} / \mathrm{A}$ & 5.00 & 23.30 & 0.60 & 1.18 & 2.18 & 8.95 & 24.13 & 15.42 & 19.41 & 8.16 & 4.63 & 3.48 & 2.49 & 11.60 \\
\hline $20-25$ & $\mathrm{~A} 3$ & T16 & $\mathrm{N} / \mathrm{A}$ & 6.70 & 28.80 & 0.37 & 0.81 & 1.18 & 21.01 & 49.87 & 12.19 & 3.46 & 2.01 & 1.24 & 1.00 & 0.80 & 3.44 \\
\hline $30-35$ & A3 & T16 & $\mathrm{N} / \mathrm{A}$ & 6.10 & 28.40 & 0.06 & 0.34 & 1.06 & 21.04 & 49.68 & 12.66 & 4.45 & 2.59 & 1.47 & 1.25 & 0.91 & 4.22 \\
\hline $40-45$ & A3 & $\mathrm{T} 16$ & $\mathrm{~N} / \mathrm{A}$ & 5.30 & 26.30 & 0.00 & 0.25 & 0.82 & 10.57 & 53.74 & 20.58 & 5.31 & 2.13 & 1.13 & 0.90 & 0.73 & 3.64 \\
\hline $50-55$ & A3 & $\mathrm{T} 16$ & $\mathrm{~N} / \mathrm{A}$ & 5.40 & 27.00 & 0.00 & 0.06 & 0.21 & 6.67 & 47.75 & 26.37 & 7.68 & 3.21 & 1.73 & 1.26 & 1.03 & 5.14 \\
\hline $60-65$ & $\mathrm{~A} 3$ & $T 16$ & $\mathrm{~N} / \mathrm{A}$ & 6.70 & 22.70 & 0.00 & 0.05 & 0.39 & 17.66 & 55.98 & 15.92 & 3.96 & 1.51 & 0.96 & 0.66 & 0.67 & 2.28 \\
\hline 70-75 & $\mathrm{A} 3$ & $\mathrm{~T} 16$ & $\mathrm{~N} / \mathrm{A}$ & 5.70 & 34.40 & 0.00 & 0.02 & 0.13 & 17.73 & 67.21 & 9.88 & 1.52 & 0.71 & 0.35 & 0.39 & 0.28 & 1.70 \\
\hline $82-87$ & $\mathrm{~A} 3$ & $T 16$ & $\mathrm{~N} / \mathrm{A}$ & 4.90 & 18.10 & 0.07 & 0.19 & 0.26 & 1.36 & 11.26 & 24.71 & 21.99 & 14.60 & 7.27 & 3.98 & 3.04 & 11.24 \\
\hline $93-98$ & A3 & T16 & $\mathrm{N} / \mathrm{A}$ & 5.60 & 18.10 & 0.09 & 0.23 & 0.35 & 1.26 & 12.59 & 25.67 & 21.39 & 13.05 & 6.79 & 4.23 & 3.34 & 10.79 \\
\hline \begin{tabular}{|c|}
$100-105$ \\
\end{tabular} & A3 & $\mathrm{T} 16$ & $\mathrm{~N} / \mathrm{A}$ & 4.90 & 17.70 & 0.11 & 0.54 & 1.04 & 1.79 & 10.18 & 24.53 & 22.23 & 14.33 & 7.16 & 4.14 & 3.03 & 10.93 \\
\hline \begin{tabular}{|l|}
$110-115$ \\
\end{tabular} & $\mathrm{~A} 3$ & $T 16$ & $\mathrm{~N} / \mathrm{A}$ & 4.70 & 17.40 & 0.14 & 1.01 & 1.42 & 2.04 & 10.54 & 24.79 & 21.95 & 13.85 & 6.90 & 4.08 & 2.82 & 10.43 \\
\hline $120-125$ & A3 & $\mathrm{T16}$ & $\mathrm{N} / \mathrm{A}$ & 5.00 & 17.40 & 0.71 & 2.06 & 1.66 & 1.93 & 11.64 & 25.14 & 20.70 & 13.55 & 6.63 & 3.81 & 2.88 & 10.03 \\
\hline $10-15$ & $\bar{A} 8$ & $\mathrm{T2}$ & 31RD1173 & 6.00 & 34.00 & 0.97 & 1.61 & 2.67 & 11.02 & 13.20 & 9.58 & 11.45 & 11.33 & 7.24 & 4.21 & 3.71 & 21.05 \\
\hline $20-25$ & A8 & $\mathrm{T} 2$ & 31RD1173 & 6.40 & 30.90 & 2.60 & 1.83 & 2.21 & 6.82 & 16.08 & 14.93 & 12.96 & 9.53 & 6.16 & 4.36 & 3.72 & 17.96 \\
\hline $30-35$ & A8 & $\mathrm{T} 2$ & 31RD1173 & 6.50 & 31.70 & 0.06 & 0.20 & 2.02 & 33.00 & 41.70 & 7.06 & 2.85 & 2.10 & 1.55 & 1.25 & 1.04 & 5.08 \\
\hline $40-45$ & A8 & T2 & 31 RD1173 & 7.50 & 21.60 & 0.12 & 0.92 & 2.29 & 16.73 & 40.51 & 11.85 & 6.54 & 4.85 & 3.77 & 2.58 & 2.08 & 5.98 \\
\hline $50-55$ & A8 & T2 & 31RD1173 & 6.10 & 15.50 & 0.25 & 0.87 & 2.91 & 11.77 & 16.87 & 14.10 & 12.89 & 12.94 & 8.29 & 4.92 & 3.26 & 8.29 \\
\hline $60-65$ & A8 & $\mathrm{T} 2$ & 31RD1173 & 5.80 & 18.50 & 0.34 & 1.11 & 2.75 & 13.46 & 18.48 & 13.89 & 12.17 & 11.87 & 6.89 & 4.02 & 2.92 & 9.31 \\
\hline $70-75$ & $\mathrm{~A} 8$ & $\mathrm{~T} 2$ & 31RD1173 & 5.80 & 31.60 & 0.38 & 0.70 & 2.65 & 14.58 & 19.64 & 12.81 & 10.52 & 9.58 & 5.61 & 3.42 & 2.88 & 15.68 \\
\hline $80-85$ & A8 & $\mathrm{T} 2$ & 31RD1173 & 4.90 & 45.90 & 0.29 & 0.80 & 2.52 & 16.65 & 21.58 & 11.79 & 7.74 & 6.34 & 3.87 & 2.66 & 2.29 & 21.41 \\
\hline $90-95$ & A8 & T2 & 31RD1173 & 4.70 & 56.50 & 0.19 & 0.48 & 3.11 & 17.80 & 22.72 & 11.03 & 5.38 & 4.71 & 2.92 & 2.06 & 2.11 & 25.34 \\
\hline 100-105 & A8 & T2 & $31 \mathrm{RD} 1173$ & 4.40 & 57.60 & 0.04 & 0.49 & 4.33 & 21.15 & 23.59 & 10.76 & 4.96 & 4.21 & 2.42 & 1.83 & 1.75 & 22.86 \\
\hline 110-115 & $A 8$ & T2 & 31RD1173 & 4.30 & 58.20 & 0.12 & 0.41 & 4.86 & 22.31 & 23.95 & 10.86 & 4.89 & 3.72 & 2.14 & 1.69 & 1.62 & 21.89 \\
\hline $0-5$ & A9 & T5 & $31 \mathrm{RD} 376$ & & & 0.00 & 011 & 0.51 & 6.65 & 25.14 & 20.35 & & & & & & \\
\hline 10 & A9 & T5 & $31 \mathrm{RD} 376$ & 6.90 & 28.70 & 0.00 & 0.26 & 0.87 & 6.87 & 22.16 & 19.03 & 12.56 & 9.35 & 6.98 & 4.34 & 3.57 & 14.83 \\
\hline 20 & A9 & T5 & 31RD376 & 5.00 & 25.20 & 0.00 & .00 & 0.18 & 9.95 & 37.89 & 23.68 & 10.85 & 4.65 & 2.70 & 1.55 & 1.41 & 7.10 \\
\hline 30 & A9 & $T 5$ & 31RD376 & 5.00 & 17.10 & 0.02 & 0.04 & 0.16 & 9.5 & 37.17 & 24.47 & 11.41 & 6.07 & 2.94 & 1.58 & 1.41 & 4.83 \\
\hline 40 & A9 & T5 & $31 \mathrm{RD} 376$ & 5.00 & 19.60 & 0.00 & 0.00 & 0.48 & 9.88 & 36.23 & 24.36 & 12.15 & 5.71 & 3.01 & 1.80 & 1.50 & 5.90 \\
\hline 50 & A9 & T5 & 31RD376 & 5.20 & 21.70 & 0.00 & 0.08 & 0.54 & 11.09 & 36.44 & 23.51 & 10.52 & 5.95 & 3.29 & 1.93 & 1.54 & 6.43 \\
\hline 60 & A9 & T5 & $31 \mathrm{RD} 376$ & 4.90 & 16.70 & 0.00 & 0.02 & 0.19 & 9.60 & 35.46 & 23.68 & 12.77 & 6.25 & 3.25 & 1.98 & 1.52 & 5.16 \\
\hline 70 & A9 & T5 & 31RD376 & 5.50 & 20.30 & 0.00 & 0.21 & 0.21 & 9.40 & 34.53 & 23.72 & 11.38 & 6.56 & 3.63 & 2.28 & 1.77 & 6.53 \\
\hline 80 & A9 & $T 5$ & 31RD376 & 5.30 & 31.50 & 0.00 & 0.11 & 0.22 & 7.65 & 30.26 & 22.57 & 11.47 & 6.96 & 3.89 & 2.52 & 2.08 & 12.38 \\
\hline 90 & A9 & T5 & 31 RD376 & 4.90 & 30.50 & 1.15 & 0.23 & 0.42 & 5.22 & 24.99 & 21.71 & 13.76 & 7.92 & 4.62 & 2.92 & 2.31 & 14.37 \\
\hline 100 & A9 & T5 & 31RD376 & 4.90 & 37.30 & 0.17 & 0.17 & 0.17 & 4.39 & 21.38 & 21.55 & 13.26 & 8.89 & 5.05 & 3.21 & 2.58 & 19.63 \\
\hline $0-5$ & A9 & T6 & 31RD283 & & & 0.41 & 1.75 & 2.80 & 6.46 & 13.86 & 14.79 & & & & & & \\
\hline
\end{tabular}




\begin{tabular}{|c|c|c|c|c|c|c|c|c|c|c|c|c|c|c|c|c|c|}
\hline \multicolumn{2}{|c|}{ Historic sediment } & \multicolumn{2}{|c|}{ Prehistoric sediment } & \multirow[b]{2}{*}{ Weight } & \multirow[b]{2}{*}{ Weight } & \multirow[b]{2}{*}{$\begin{array}{l}\text { Percent } \\
\text { Whole }\end{array}$} & \multirow[b]{2}{*}{$\begin{array}{l}\text { Percent } \\
\text { Whole }\end{array}$} & \multirow[b]{2}{*}{$\begin{array}{l}\text { Percent } \\
\text { Whole }\end{array}$} & \multirow[b]{2}{*}{$\begin{array}{l}\text { Percent } \\
\text { Whole }\end{array}$} & \multirow[b]{2}{*}{$\begin{array}{l}\text { Percent } \\
\text { Whole }\end{array}$} & \multirow[b]{2}{*}{$\begin{array}{l}\text { Percent } \\
\text { Whole }\end{array}$} & \multirow[b]{2}{*}{$\begin{array}{l}\text { Percent } \\
\text { Whole }\end{array}$} & \multirow[b]{2}{*}{\begin{tabular}{|l|} 
Percent \\
Whole
\end{tabular}} & \multirow[b]{2}{*}{\begin{tabular}{|l|} 
Percent \\
Whole
\end{tabular}} & \multirow[b]{2}{*}{\begin{tabular}{|c|} 
Percent \\
Whole
\end{tabular}} & \multirow[b]{2}{*}{\begin{tabular}{|l|} 
Percent \\
Whole
\end{tabular}} & \multirow[b]{2}{*}{$\begin{array}{l}\text { Percent } \\
\text { Whole }\end{array}$} \\
\hline & & & & & & & & & & & & & & & & & \\
\hline Depth & $\begin{array}{c}\text { Area } \\
\text { Location }\end{array}$ & \begin{tabular}{|c|} 
Trench \\
Number
\end{tabular} & Site Number & $\begin{array}{c}<8.0-9.0 \\
\text { phi }\end{array}$ & $\begin{array}{l}<9 \text { phi } \\
\text { (finer } \\
\text { than) }\end{array}$ & $\begin{array}{c}-1.0 \mathrm{phi} \\
\text { and } \\
\text { greater }\end{array}$ & $\begin{array}{c}<-1.0-0.0 \\
\text { phi }\end{array}$ & $\begin{array}{c}<0-1.0 \\
\text { phi }\end{array}$ & $\begin{array}{c}<1.0-2.0 \\
\text { phi }\end{array}$ & $\begin{array}{c}<2.0-3.0 \\
\text { phi }\end{array}$ & $\begin{array}{c}<3.0-4.0 \\
\text { phi }\end{array}$ & $\begin{array}{c}<4.0-5.0 \\
\text { phi }\end{array}$ & $\begin{array}{c}<5.0-6.0 \\
\mathrm{phi}\end{array}$ & \begin{tabular}{|c|}
$<6.0-7.0$ \\
phi
\end{tabular} & $\begin{array}{c}<7.0-8.0 \\
\text { phi }\end{array}$ & $\begin{array}{c}<8.0-9.0 \\
\text { phi }\end{array}$ & $\begin{array}{c}<9 \text { phi } \\
\text { (finer than) }\end{array}$ \\
\hline 15 & A9 & T6 & 31RD283 & 7.20 & 31.80 & 1.67 & 1.14 & 3.21 & 12.52 & 22.14 & 14.01 & 9.51 & 8.00 & 6.08 & 4.30 & 3.29 & 14.54 \\
\hline 25 & A9 & T6 & $31 \mathrm{RD} 283$ & & & 1.85 & 1.53 & 2.65 & 12.27 & 22.02 & 14.18 & & & & & & \\
\hline 35 & $\mathrm{A9}$ & T6 & $31 \mathrm{RD} 283$ & 6.50 & 35.90 & 0.72 & 0.56 & 1.45 & 13.51 & 27.18 & 15.20 & 7.24 & 7.03 & 5.24 & 3.90 & 2.64 & 14.60 \\
\hline 45 & A9 & T6 & $31 \mathrm{RD} 283$ & & & 1.92 & 1.33 & 2.29 & 13.35 & 24.79 & 15.57 & & & & & & \\
\hline 55 & A9 & T6 & $31 \mathrm{RD} 283$ & 5.80 & 28.70 & 0.00 & 0.51 & 2.77 & 26.38 & 24.67 & 11.91 & 8.39 & 6.22 & 4.15 & 2.80 & 1.91 & 9.44 \\
\hline $61-63$ & A9 & T6 & $31 \mathrm{RD} 283$ & 7.80 & 28.00 & 0.13 & 0.89 & 4.79 & 33.75 & 26.12 & 9.92 & 5.48 & 4.47 & 3.33 & 2.22 & 1.88 & 6.76 \\
\hline $68-72$ & A9 & T6 & $31 \mathrm{RD} 283$ & 6.80 & 29.10 & 0.06 & 0.73 & 2.02 & 16.08 & 28.69 & 15.07 & 8.37 & 6.86 & 4.70 & 3.63 & 2.49 & 10.68 \\
\hline 75-77 & A9 & T6 & $31 \mathrm{RD} 283$ & & & 0.72 & 0.61 & 1.74 & 16.67 & 30.57 & 15.95 & & & & & & \\
\hline $82-84$ & A9 & T6 & 31RD283 & 7.30 & 22.40 & 0.00 & 0.22 & 1.59 & 14.68 & 30.28 & 17.15 & 9.74 & 7.14 & 4.89 & 3.35 & 2.60 & 7.99 \\
\hline $87-89$ & A9 & T6 & $31 \mathrm{RD} 283$ & & & 0.00 & 0.28 & 1.47 & 14.05 & 28.83 & 16.99 & & & & & & \\
\hline 95 & A9 & T6 & $31 \mathrm{RD283}$ & 7.00 & 24.50 & 0.00 & 0.19 & 1.60 & 12.61 & 27.59 & 17.31 & 9.80 & 7.70 & 5.95 & 4.29 & 2.84 & 9.92 \\
\hline $0-5$ & A9 & $\mathrm{T} 12$ & 31RD282 & & & 0.67 & 0.62 & 1.43 & 2.34 & 3.73 & 5.93 & & & & & & \\
\hline 15 & A9 & T12 & 31RD282 & & & 0.00 & 0.05 & 0.32 & 0.27 & 0.70 & 7.60 & & & & & & \\
\hline 25 & A9 & $\mathrm{T} 12$ & $31 \mathrm{RD} 282$ & & & 0.00 & 0.10 & 0.20 & 0.26 & 0.56 & 5.22 & & & & & & \\
\hline 35 & A9 & $T 12$ & 31 RD282 & & & 0.00 & 0.04 & 0.09 & 0.31 & 0.49 & 2.20 & & & & & & \\
\hline 45 & A9 & T12 & 31RD282 & & & 0.12 & 0.08 & 0.16 & 0.31 & 0.59 & 9.44 & & & & & & \\
\hline $55-59$ & A9 & T12 & 31 RD282 & & & 4.83 & 4.93 & 6.01 & 12.48 & 16.13 & 12.12 & & & & & & \\
\hline 65 & A9 & T12 & $31 \mathrm{RD} 282$ & & & 0.73 & 2.66 & 4.60 & 14.92 & 18.55 & 13.12 & & & & & & \\
\hline 75 & A9 & $\mathrm{T} 12$ & $31 \mathrm{RD} 282$ & & & 1.70 & 3.70 & 5.94 & 14.16 & 20.33 & 13.84 & & & & & & \\
\hline 85 & A9 & $\mathrm{T} 12$ & 31RD282 & & & 0.57 & 2.76 & 5.82 & 10.67 & 19.29 & 15.53 & & & & & & \\
\hline 95 & A9 & $T 12$ & $31 \mathrm{RD} 282$ & & & 1.51 & 2.88 & 5.21 & 9.72 & 17.72 & 14.39 & & & & & & \\
\hline 105 & A9 & $\mathrm{T} 12$ & $31 \mathrm{RD} 282$ & & & 1.75 & 3.14 & 5.13 & 9.08 & 17.18 & 14.08 & & & & & & \\
\hline 115 & A9 & T12 & $31 \mathrm{RD} 282$ & & & 0.65 & 2.70 & 4.38 & 8.90 & 17.39 & 13.66 & & & & & & \\
\hline & & & & & & & & & & & & & & & & & \\
\hline
\end{tabular}




\begin{tabular}{|c|c|c|c|c|c|c|c|c|c|c|c|c|}
\hline Depth & $\begin{array}{c}\text { Area } \\
\text { Location }\end{array}$ & $\begin{array}{l}\text { Trench } \\
\text { Number }\end{array}$ & $\begin{array}{c}\text { Site } \\
\text { Number }\end{array}$ & $16 \%$ & $25 \%$ & $50 \%$ & $75 \%$ & $84 \%$ & Median & $\begin{array}{c}\text { Graphic } \\
\text { Mean }\end{array}$ & $\begin{array}{c}\text { Graphic } \\
\text { Standard } \\
\text { Deviation }\end{array}$ & $\begin{array}{c}\text { Graphic } \\
\text { Skewness }\end{array}$ \\
\hline $0-5$ & $\mathrm{~A} 2$ & $\mathrm{~T} 1$ & 31RD1163 & & & & & & & & & \\
\hline 10 & A2 & T1 & 31RD1163 & 2.9 & 3.5 & 4.9 & 7.4 & 9.5 & 4.9 & 5.77 & 3.30 & 0.39 \\
\hline 20 & $\mathrm{~A} 2$ & $\mathrm{~T} 1$ & 31RD1163 & 2.8 & 3.2 & 4.5 & 6.7 & 8.6 & 4.5 & 5.30 & 2.90 & 0.41 \\
\hline 30 & $\mathrm{~A} 2$ & $\mathrm{~T} 1$ & 31RD1163 & 2.7 & 3.1 & 4.2 & 6.2 & 8.2 & 4.2 & 5.03 & 2.75 & 0.45 \\
\hline 40 & $\mathrm{~A} 2$ & $\mathrm{~T} 1$ & 31RD1163 & 2.8 & 3.3 & 4.5 & 6.3 & 8.5 & 4.5 & 5.27 & 2.85 & 0.40 \\
\hline 50 & $\mathrm{~A} 2$ & $\mathrm{~T} 1$ & 31RD1163 & 2.9 & 3.1 & 4.6 & 6.5 & 8.3 & 4.6 & 5.27 & 2.70 & 0.37 \\
\hline 60 & $\mathrm{~A} 2$ & $\mathrm{~T} 1$ & 31RD1163 & 2.8 & 3.2 & 4.5 & 6.5 & 8.3 & 4.5 & 5.20 & 2.75 & 0.38 \\
\hline 70 & $\mathrm{~A} 2$ & $\mathrm{~T} 1$ & 31RD1163 & 2.5 & 2.8 & 3.7 & 5.5 & 6.9 & 3.7 & 4.37 & 2.20 & 0.45 \\
\hline 80 & $\mathrm{~A} 2$ & $\mathrm{~T} 1$ & 31RD1163 & 2.7 & 3 & 4.1 & 6.1 & 8.3 & 4.1 & 5.03 & 2.80 & 0.50 \\
\hline 90 & $\mathrm{~A} 2$ & $\mathrm{~T} 1$ & 31RD1163 & & & & & & & & & \\
\hline 100 & $\mathrm{~A} 2$ & $\mathrm{~T} 1$ & 31RD1163 & 2.9 & 3.2 & 4.1 & 6.1 & 8.5 & 4.1 & 5.17 & 2.80 & 0.57 \\
\hline 110 & $\mathrm{~A} 2$ & $\mathrm{~T} 1$ & 31RD1163 & 2.7 & 3.1 & 4 & 6 & 8.2 & 4 & 4.97 & 2.75 & 0.53 \\
\hline 120 & $\mathrm{~A} 2$ & T1 & 31RD1163 & 2.7 & 2.9 & 3.9 & 5.2 & 8.5 & 3.9 & 5.03 & 2.90 & 0.59 \\
\hline 130 & $\mathrm{~A} 2$ & $\mathrm{~T} 1$ & 31RD1163 & 2.6 & 2.8 & 3.5 & 4.9 & 6.2 & 3.5 & 4.10 & 1.80 & 0.50 \\
\hline 140 & $\mathrm{~A} 2$ & $\mathrm{~T} 1$ & 31RD1163 & 2.3 & 2.5 & 3.2 & 4.5 & 5.5 & 3.2 & 3.67 & 1.60 & 0.44 \\
\hline 150 & $\mathrm{~A} 2$ & $\mathrm{~T} 1$ & 31RD1163 & & & & & & & & & \\
\hline $0-5$ & $\mathrm{~A} 2$ & $\mathrm{~T} 7$ & 31RD1164 & & & & & & & & & \\
\hline 10 & $\mathrm{~A} 2$ & T7 & 31RD1164 & 1.9 & 2.3 & 3.5 & 5.2 & 6.4 & 3.5 & 3.93 & 2.25 & 0.29 \\
\hline 20 & $\mathrm{~A} 2$ & $\mathrm{T7}$ & 31RD1164 & 1.9 & 2.3 & 3.5 & 5.3 & 6.6 & 3.5 & 4.00 & 2.35 & 0.32 \\
\hline 30 & $\mathrm{~A} 2$ & $\mathrm{~T} 7$ & 31RD1164 & 1.8 & 2.3 & 3.5 & 5 & 6 & 3.5 & 3.77 & 2.10 & 0.19 \\
\hline 40 & $\mathrm{~A} 2$ & $\mathrm{~T} 7$ & 31RD1164 & 1.6 & 2 & 2.8 & 3.6 & 4 & 2.8 & 2.80 & 1.20 & 0.00 \\
\hline 50 & $\mathrm{~A} 2$ & $\mathrm{~T} 7$ & 31RD1164 & 1.7 & 2.2 & 3.5 & 5.3 & 6.6 & 3.5 & 3.93 & 2.45 & 0.27 \\
\hline 60 & $\mathrm{~A} 2$ & $\mathrm{~T} 7$ & 31RD1164 & 1.8 & 1.9 & 2.9 & 4.9 & 6 & 2.9 & 3.57 & 2.10 & 0.48 \\
\hline 70 & $\mathrm{~A} 2$ & $\mathrm{T7}$ & 31RD1164 & 1.8 & 2.2 & 3.5 & 5.5 & 6.7 & 3.5 & 4.00 & 2.45 & 0.31 \\
\hline 80 & $\mathrm{~A} 2$ & T7 & 31RD1164 & 2.1 & 2.7 & 3.9 & 5.5 & 6.7 & 3.9 & 4.23 & 2.30 & 0.22 \\
\hline 90 & $\mathrm{~A} 2$ & $\mathrm{~T} 7$ & 31RD1164 & 2.3 & 2.8 & 4.1 & 6 & 7.5 & 4.1 & 4.63 & 2.60 & 0.31 \\
\hline 100 & $\mathrm{~A} 2$ & $\mathrm{T7}$ & 31RD1164 & 1.9 & 2.5 & 4 & 6 & 8 & 4 & 4.63 & 3.05 & 0.31 \\
\hline 110 & $\mathrm{~A} 2$ & $\mathrm{~T} 7$ & 31RD1164 & 1.9 & 2.5 & 3.9 & 6.1 & 7.8 & 3.9 & 4.53 & 2.95 & 0.32 \\
\hline 120 & $\mathrm{~A} 2$ & $\mathrm{~T} 7$ & 31RD1164 & 1.6 & 2.4 & 3.9 & 5.9 & 7.5 & 3.9 & 4.33 & 2.95 & 0.22 \\
\hline $10-15$ & A3 & T8 & 31RD1166 & & & & & & & & & \\
\hline $20-25$ & A3 & T8 & 31RD1166 & 2.1 & 2.5 & 3.2 & 4.9 & 5.9 & 3.2 & 3.73 & 1.90 & 0.42 \\
\hline $30-35$ & A3 & T8 & 31RD1166 & 2.1 & 2.7 & 3.7 & 5.8 & 8.6 & 3.7 & 4.80 & 3.25 & 0.51 \\
\hline $40-45$ & A3 & T8 & 31RD1166 & 2.2 & 2.7 & 3.7 & 5.5 & 6.9 & 3.7 & 4.27 & 2.35 & 0.36 \\
\hline $50-55$ & A3 & T8 & 31RD1166 & 2.1 & 2.9 & 4.1 & 6.9 & 10 & 4.1 & 5.40 & 3.95 & 0.49 \\
\hline $60-65$ & A3 & T8 & 31RD1166 & & & & & & & & & \\
\hline $70-75$ & A3 & T8 & 31RD1166 & 2 & 2.7 & 4 & 8.5 & 12.6 & 4 & 6.20 & 5.30 & 0.62 \\
\hline $80-85$ & A3 & T8 & 31RD1166 & 1.9 & 2.4 & 3.7 & 7.8 & 11.3 & 3.7 & 5.63 & 4.70 & 0.62 \\
\hline $85-90$ & A3 & T8 & 31RD1166 & -1.1 & -0.4 & 2.4 & 6.3 & 11.4 & 2.4 & 4.23 & 6.25 & 0.44 \\
\hline 90-95 & A3 & T8 & 31RD1166 & 1.9 & 2.4 & 3.7 & 9.3 & 11.7 & 3.7 & 5.77 & 4.90 & 0.63 \\
\hline 100-105 & A3 & $\mathrm{T} 8$ & 31RD1166 & 2 & 2.4 & 3.5 & 8.8 & 13 & 3.5 & 6.17 & 5.50 & 0.73 \\
\hline $5-7$ & A3 & $\mathrm{T} 13$ & 31RD1166 & & & & & & & & & \\
\hline $18-20$ & A3 & T13 & 31RD1166 & & & & & & & & & \\
\hline $34-36$ & A3 & T13 & 31RD1166 & 1.7 & 1.8 & 2.3 & 2.7 & 3.1 & 2.3 & 2.37 & 0.70 & 0.14 \\
\hline $38-40$ & A3 & T13 & 31RD1166 & 2.5 & 2.7 & 3.5 & 4.7 & 6 & 3.5 & 4.00 & 1.75 & 0.43 \\
\hline $46-48$ & A3 & T13 & 31RD1166 & 2.4 & 2.7 & 3.5 & 4.6 & 5.9 & 3.5 & 3.93 & 1.75 & 0.37 \\
\hline $55-57$ & A3 & T13 & 31RD1166 & 2.4 & 2.7 & 3.5 & 4.7 & 5.6 & 3.5 & 3.83 & 1.60 & 0.31 \\
\hline $70-75$ & A3 & T13 & 31RD1166 & 2.4 & 2.7 & 3.5 & 5.2 & 8.4 & 3.5 & 4.77 & 3.00 & 0.63 \\
\hline $85-90$ & A3 & T13 & 31RD1166 & 2.3 & 2.6 & 3.5 & 4.7 & 5.3 & 3.5 & 3.70 & 1.50 & 0.20 \\
\hline $105-110$ & A3 & T13 & 31RD1166 & 2.1 & 2.6 & 3.8 & 6.3 & 9.2 & 3.8 & 5.03 & 3.55 & 0.52 \\
\hline 125-130 & A3 & T13 & 31RD1166 & 2.1 & 2.6 & 4.1 & 8.5 & 11.3 & 4.1 & 5.83 & 4.60 & 0.57 \\
\hline $20-25$ & A3 & T14 & 31RD128 & 2.1 & 2.4 & 3.0 & 4.3 & 5.3 & 3.0 & 3.47 & 1.60 & 0.44 \\
\hline $33-40$ & A3 & T14 & 31RD128 & 2.5 & 2.8 & 3.7 & 5.2 & 6.5 & 3.7 & 4.23 & 2.00 & 0.40 \\
\hline $45-50$ & A3 & T14 & 31RD128 & 2.5 & 2.8 & 3.7 & 5.2 & 6.2 & 3.7 & 4.13 & 1.85 & 0.35 \\
\hline $65-70$ & A3 & T14 & 31RD128 & 3.4 & 3.7 & 4.5 & 5.6 & 6.5 & 4.5 & 4.80 & 1.55 & 0.29 \\
\hline $85-90$ & $\mathrm{~A} 3$ & T14 & 31RD128 & 2.4 & 2.6 & 3.1 & 4.0 & 4.7 & 3.1 & 3.40 & 1.15 & 0.39 \\
\hline
\end{tabular}




\begin{tabular}{|c|c|c|c|c|c|c|c|c|c|c|c|c|}
\hline Depth & $\begin{array}{c}\text { Area } \\
\text { Location }\end{array}$ & $\begin{array}{l}\text { Trench } \\
\text { Number }\end{array}$ & $\begin{array}{c}\text { Site } \\
\text { Number }\end{array}$ & $16 \%$ & $25 \%$ & $50 \%$ & $75 \%$ & $84 \%$ & Median & $\begin{array}{c}\text { Graphic } \\
\text { Mean }\end{array}$ & $\begin{array}{l}\text { Graphic } \\
\text { Standard } \\
\text { Deviation }\end{array}$ & $\begin{array}{c}\text { Graphic } \\
\text { Skewness }\end{array}$ \\
\hline $100-105$ & A3 & $\mathrm{T} 14$ & 31RD128 & 2.4 & 2.7 & 3.3 & 4.5 & 5.7 & 3.3 & 3.80 & 1.65 & 0.45 \\
\hline $0-2$ & A3 & T16 & $\mathrm{N} / \mathrm{A}$ & & & & & & & & & \\
\hline $10-15$ & A3 & $\mathrm{T} 16$ & $\mathrm{~N} / \mathrm{A}$ & 2.1 & 2.35 & 3.8 & 5.5 & 7 & 3.8 & 4.30 & 2.45 & 0.31 \\
\hline $20-25$ & A3 & T16 & N/A & 1.9 & 2.1 & 2.5 & 2.9 & 3.9 & 2.5 & 2.77 & 1.00 & 0.40 \\
\hline $30-35$ & A3 & $\mathrm{T} 16$ & $\mathrm{~N} / \mathrm{A}$ & 1.8 & 2.1 & 2.6 & 3.2 & 4 & 2.6 & 2.80 & 1.10 & 0.27 \\
\hline $40-45$ & A3 & T16 & $\mathrm{N} / \mathrm{A}$ & 2.2 & 2.4 & 2.7 & 3.4 & 3.9 & 2.7 & 2.93 & 0.85 & 0.41 \\
\hline $50-55$ & A3 & T16 & N/A & 2.3 & 2.5 & 2.9 & 3.7 & 4.3 & 2.9 & 3.17 & 1.00 & 0.40 \\
\hline $60-65$ & A3 & $\mathrm{T} 16$ & N/A & 1.9 & 2.1 & 2.5 & 3 & 3.5 & 2.5 & 2.63 & 0.80 & 0.25 \\
\hline $70-75$ & A3 & T16 & $\mathrm{N} / \mathrm{A}$ & 1.9 & 2.1 & 2.5 & 2.8 & 3 & 2.5 & 2.47 & 0.55 & -0.09 \\
\hline $82-87$ & A3 & T16 & $\mathrm{N} / \mathrm{A}$ & 3.1 & 3.5 & 4.5 & 6.1 & 7.7 & 4.5 & 5.10 & 2.30 & 0.39 \\
\hline $93-98$ & A3 & T16 & $\mathrm{N} / \mathrm{A}$ & 3.1 & 3.5 & 4.5 & 6.1 & 7.7 & 4.5 & 5.10 & 2.30 & 0.39 \\
\hline $100-105$ & A3 & T16 & N/A & 3.1 & 3.5 & 4.5 & 6.1 & 7.8 & 4.5 & 5.13 & 2.35 & 0.40 \\
\hline $110-115$ & A3 & T16 & $\mathrm{N} / \mathrm{A}$ & 3.1 & 3.5 & 4.5 & 5.9 & 7.5 & 4.5 & 5.03 & 2.20 & 0.36 \\
\hline $120-125$ & A3 & $\mathrm{T} 16$ & $\mathrm{~N} / \mathrm{A}$ & 2.9 & 3.3 & 4.3 & 5.9 & 7.3 & 4.3 & 4.83 & 2.20 & 0.36 \\
\hline $10-15$ & A8 & $\mathrm{T} 2$ & 31RD1173 & 2.0 & 2.7 & 4.9 & 8.3 & 11.3 & 4.9 & 6.07 & 4.65 & 0.38 \\
\hline $20-25$ & A8 & $\mathrm{T} 2$ & 31RD1173 & 2.2 & 2.8 & 4.5 & 7.7 & 10.8 & 4.5 & 5.83 & 4.30 & 0.47 \\
\hline $30-35$ & A8 & $\mathrm{T} 2$ & 31RD1173 & 1.6 & 1.8 & 2.4 & 2.9 & 4.0 & 2.4 & 2.67 & 1.20 & 0.33 \\
\hline $40-45$ & A8 & T2 & 31RD1173 & 1.8 & 2.1 & 2.7 & 4.5 & 6.0 & 2.7 & 3.50 & 2.10 & 0.57 \\
\hline $50-55$ & A8 & $\mathrm{T} 2$ & 31RD1173 & 2.1 & 2.6 & 4.3 & 6.3 & 7.7 & 4.3 & 4.70 & 2.80 & 0.21 \\
\hline $60-65$ & A8 & $\mathrm{T} 2$ & 31RD1173 & 1.9 & 2.8 & 4.0 & 6.3 & 7.8 & 4.0 & 4.57 & 2.95 & 0.29 \\
\hline $70-75$ & A8 & $\mathrm{T} 2$ & 31RD1173 & 1.9 & 2.4 & 4.0 & 6.8 & 9.5 & 4.0 & 5.13 & 3.80 & 0.45 \\
\hline $80-85$ & A8 & T2 & 31RD1173 & 1.8 & 2.2 & 3.7 & 8.5 & 12.3 & 3.7 & 5.93 & 5.25 & 0.64 \\
\hline $90-95$ & A8 & $\mathrm{T} 2$ & 31RD1173 & 1.8 & 2.2 & 3.5 & 10.0 & 14.4 & 3.5 & 6.57 & 6.30 & 0.73 \\
\hline $100-105$ & A8 & T2 & 31RD1173 & 1.7 & 1.9 & 3.1 & 9.0 & 13.6 & 3.1 & 6.13 & 5.95 & 0.76 \\
\hline $110-115$ & A8 & $\mathrm{T} 2$ & 31RD1173 & 1.6 & 1.9 & 2.8 & 8.5 & 14.0 & 2.8 & 6.13 & 6.20 & 0.81 \\
\hline $0-5$ & A9 & T5 & 31RD376 & & & & & & & & & \\
\hline 10 & A9 & T5 & 31RD376 & 2.4 & 2.8 & 4.1 & 6.6 & 8.2 & 4.1 & 4.90 & 2.90 & 0.41 \\
\hline 20 & A9 & T5 & 31RD376 & 2.2 & 2.5 & 3.1 & 4.3 & 5.3 & 3.1 & 3.53 & 1.55 & 0.42 \\
\hline 30 & A9 & T5 & 31RD376 & 2.3 & 2.5 & 3.1 & 4.3 & 5.3 & 3.1 & 3.57 & 1.50 & 0.47 \\
\hline 40 & A9 & T5 & 31RD376 & 2.2 & 2.5 & 3.1 & 4.3 & 5.2 & 3.1 & 3.50 & 1.50 & 0.40 \\
\hline 50 & A9 & T5 & 31RD376 & 2.1 & 2.4 & 3.1 & 4.3 & 5.3 & 3.1 & 3.50 & 1.60 & 0.38 \\
\hline 60 & A9 & T5 & 31RD376 & 2.3 & 2.5 & 3.2 & 4.5 & 5.4 & 3.2 & 3.63 & 1.55 & 0.42 \\
\hline 70 & A9 & T5 & 31RD376 & 2.3 & 2.5 & 3.2 & 4.6 & 5.2 & 3.2 & 3.57 & 1.45 & 0.38 \\
\hline 80 & A9 & T5 & 31RD376 & 2.4 & 2.7 & 3.7 & 5.4 & 7.4 & 3.7 & 4.50 & 2.50 & 0.48 \\
\hline 90 & A9 & T5 & 31RD376 & 2.5 & 2.8 & 3.9 & 6.2 & 8.8 & 3.9 & 5.07 & 3.15 & 0.56 \\
\hline 100 & A9 & T5 & 31RD376 & 2.7 & 2.9 & 4.2 & 7.2 & 10.8 & 4.2 & 5.90 & 4.05 & 0.63 \\
\hline $0-5$ & A9 & T6 & 31RD283 & & & & & & & & & \\
\hline 15 & A9 & T6 & 31RD283 & 1.9 & 2.4 & 3.7 & 6.6 & 9 & 3.7 & 4.87 & 3.55 & 0.49 \\
\hline 25 & A9 & T6 & 31RD283 & & & & & & & & & \\
\hline 35 & A9 & T6 & 31RD283 & 2 & 2.4 & 3.4 & 6.6 & 9 & 3.4 & 4.80 & 3.50 & 0.60 \\
\hline 45 & A9 & T6 & 31RD283 & & & & & & & & & \\
\hline 55 & A9 & T6 & 31RD283 & 1.7 & 1.9 & 2.8 & 5.1 & 6.7 & 2.8 & 3.73 & 2.50 & 0.56 \\
\hline $61-63$ & A9 & T6 & 31RD283 & 1.5 & 1.7 & 2.5 & 4 & 5.6 & 2.5 & 3.20 & 2.05 & 0.51 \\
\hline $68-72$ & A9 & T6 & 31RD283 & 1.9 & 2.3 & 3.2 & 5.7 & 7.5 & 3.2 & 4.20 & 2.80 & 0.54 \\
\hline $75-77$ & A9 & T6 & 31RD283 & & & & & & & & & \\
\hline $82-84$ & A9 & T6 & 31RD283 & 2 & 2.4 & 3.3 & 5.3 & 6.8 & 3.3 & 4.03 & 2.40 & 0.46 \\
\hline $87-89$ & A9 & T6 & 31RD283 & & & & & & & & & \\
\hline 95 & A9 & T6 & 31RD283 & 2.1 & 2.5 & 3.5 & 5.8 & 7.4 & 3.5 & 4.33 & 2.65 & 0.47 \\
\hline
\end{tabular}




\section{APPENDIX V}

Magnetic Susceptibility and Organic Matter Data 


\begin{tabular}{|c|c|c|c|c|c|c|c|}
\hline & Area & Trench & & & & $\%$ Volatile & $\begin{array}{c}\text { Magnetic } \\
\text { Susceptibility }\end{array}$ \\
\hline Depth & Location & Number & Site Number & Sample & $\%$ Ash & Material & $\left(\times 10^{\wedge}-6\right)$ \\
\hline $0-5$ & $\bar{A} 2$ & $\overline{\mathrm{T} 1}$ & 31RD1163 & A2-1 & 94.14 & 5.86 & 60 \\
\hline 10 & $\mathrm{~A} 2$ & T1 & 31RD1163 & A2-2 & 95.87 & 4.13 & 65 \\
\hline 20 & $\mathrm{~A} 2$ & T1 & 31RD1163 & A2-3 & 96.65 & 3.35 & 73 \\
\hline 30 & A2 & T1 & 31RD1163 & A2-4 & 97.12 & 2.88 & 81 \\
\hline 40 & $\mathrm{~A} 2$ & T1 & 31RD1163 & A2-5 & 97.15 & 2.85 & 79 \\
\hline 50 & $\mathrm{~A} 2$ & T1 & 31RD1163 & A2-6 & 97.25 & 2.75 & 77 \\
\hline 60 & $\mathrm{~A} 2$ & T1 & 31RD1163 & A2-7 & 97.32 & 2.68 & 74 \\
\hline 70 & $\mathrm{~A} 2$ & T1 & 31RD1163 & A2-8 & 97.89 & 2.11 & 61 \\
\hline 80 & $\mathrm{~A} 2$ & T1 & 31RD1163 & A2-9 & 97.32 & 2.68 & 65 \\
\hline 90 & $\mathrm{~A} 2$ & T1 & 31RD1163 & A2-10 & 96.86 & 3.14 & 46 \\
\hline 100 & $\mathrm{~A} 2$ & T1 & 31RD1163 & A2-11 & 97.21 & 2.79 & 40 \\
\hline 110 & $\mathrm{~A} 2$ & T1 & 31RD1163 & A2-12 & 97.4 & 2.6 & 41 \\
\hline 120 & $\mathrm{~A} 2$ & T1 & 31RD1163 & A2-13 & 97.9 & 2.1 & 36 \\
\hline 130 & $\mathrm{~A} 2$ & T1 & 31RD1163 & A2-14 & 98.31 & 1.69 & 35 \\
\hline 140 & $\mathrm{~A} 2$ & T1 & 31RD1163 & A2-15 & 98.62 & 1.38 & 33 \\
\hline 150 & $\mathrm{~A} 2$ & $\mathrm{~T} 1$ & 31RD1163 & A2-16 & 98.35 & 1.65 & 35 \\
\hline $0-5$ & $\mathrm{~A} 2$ & T7 & 31RD1164 & A2-17 & 96.3 & 3.7 & 42 \\
\hline 10 & $\mathrm{~A} 2$ & T7 & 31RD1164 & A2-18 & 97.41 & 2.59 & 44 \\
\hline 20 & $\mathrm{~A} 2$ & $\mathrm{T7}$ & 31RD1164 & A2-19 & 98.1 & 1.9 & 44 \\
\hline 30 & $\mathrm{~A} 2$ & T7 & 31RD1164 & A2-20 & 98.34 & 1.66 & 46 \\
\hline 40 & $\mathrm{~A} 2$ & T7 & 31RD1164 & A2-21 & 98.24 & 1.76 & 50 \\
\hline 50 & $\mathrm{~A} 2$ & T7 & 31RD1164 & A2-22 & 98.16 & 1.84 & 50 \\
\hline 60 & $\mathrm{~A} 2$ & T7 & 31RD1164 & A2-23 & 97.91 & 2.09 & 47 \\
\hline 70 & $\mathrm{~A} 2$ & T7 & 31RD1164 & A2-24 & 97.92 & 2.08 & 52 \\
\hline 80 & $\mathrm{~A} 2$ & T7 & 31RD1164 & A2-25 & 97.84 & 2.16 & 53 \\
\hline 90 & $\mathrm{~A} 2$ & T7 & 31RD1164 & A2-26 & 98.08 & 1.92 & 56 \\
\hline 100 & A2 & T7 & 31RD1164 & A2-27 & 98.04 & 1.96 & 52 \\
\hline 110 & $\mathrm{~A} 2$ & T7 & 31RD1164 & A2-28 & 98.22 & 1.78 & 43 \\
\hline 120 & $\mathrm{~A} 2$ & T7 & 31RD1164 & A2-29 & 98.1 & 1.9 & 48 \\
\hline $10-15$ & A3 & T8 & 31RD1166 & A3-1 & 98.19 & 1.81 & 39 \\
\hline $20-25$ & A3 & T8 & 31RD1166 & A3-2 & 98.41 & 1.59 & 40 \\
\hline $30-35$ & A3 & T8 & 31RD1166 & A3-3 & 98.37 & 1.63 & 40 \\
\hline $40-45$ & A3 & T8 & 31RD1166 & A3-4 & 98.12 & 1.88 & 42 \\
\hline $50-55$ & A3 & T8 & 31RD1166 & A3-5 & 97.04 & 2.96 & 51 \\
\hline $60-65$ & A3 & T8 & 31RD1166 & A3-6 & 96.91 & 3.09 & 48 \\
\hline $70-75$ & A3 & T8 & 31RD1166 & A3-7 & 98.84 & 1.16 & 45 \\
\hline $80-85$ & A3 & T8 & 31RD1166 & A3-8 & 96.61 & 3.39 & 43 \\
\hline $85-90$ & A3 & T8 & 31RD1166 & A3-9 & 97.33 & 2.67 & 40 \\
\hline $90-95$ & A3 & T8 & 31RD1166 & A3-10 & 96.38 & 3.62 & 52 \\
\hline $100-105$ & A3 & T8 & 31RD1166 & A3-11 & 96.22 & 3.78 & 40 \\
\hline $5-7$ & A3 & $\overline{T 13}$ & 31RD1166 & A3-12 & 97.86 & 2.14 & 30 \\
\hline $18-20$ & A3 & T13 & 31RD1166 & A3-13 & 99.2 & 0.8 & 28 \\
\hline $34-36$ & A3 & T13 & 31RD1166 & A3-14 & 99.34 & 0.66 & 27 \\
\hline $38-40$ & A3 & T13 & 31RD1166 & A3-15 & 98.42 & 1.58 & 46 \\
\hline $46-48$ & A3 & T13 & 31RD1166 & A3-16 & 98.41 & 1.59 & 44 \\
\hline $55-57$ & A3 & T13 & 31RD1166 & A3-17 & 98.42 & 1.58 & 41 \\
\hline $70-75$ & A3 & T13 & 31RD1166 & A3-18 & 98.85 & 1.15 & 37 \\
\hline $85-90$ & A3 & T13 & 31RD1166 & A3-19 & 98.5 & 1.5 & 42 \\
\hline $105-110$ & A3 & T13 & 31RD1166 & A3-20 & 97.48 & 2.52 & 47 \\
\hline $125-130$ & A3 & T13 & 31RD1166 & A3-21 & 96.81 & 3.19 & 44 \\
\hline $20-25$ & A3 & T14 & 31RD128 & A3-22 & 98.47 & 1.53 & 43 \\
\hline $33-40$ & A3 & T14 & 31RD128 & A3-23 & 97.93 & 2.07 & 54 \\
\hline $45-50$ & A3 & T14 & 31RD128 & A3-24 & 98.63 & 1.37 & 50 \\
\hline $65-70$ & A3 & T14 & 31RD128 & A3-25 & 98.93 & 1.07 & 36 \\
\hline $85-90$ & A3 & T14 & 31RD128 & A3-26 & 99.38 & 0.62 & 30 \\
\hline $100-105$ & A3 & T14 & 31RD128 & A3-27 & 98.46 & 1.54 & 40 \\
\hline $0-2$ & A3 & T16 & $\mathrm{N} / \mathrm{A}$ & A3-28 & 97.71 & 2.29 & 33 \\
\hline $10-15$ & A3 & T16 & $\mathrm{N} / \mathrm{A}$ & A3-29 & 98.27 & 1.73 & 32 \\
\hline $20-25$ & A3 & T16 & $\mathrm{N} / \mathrm{A}$ & A3-30 & 98.78 & 1.22 & 35 \\
\hline
\end{tabular}




\begin{tabular}{|c|c|c|c|c|c|c|c|}
\hline & Area & Trench & & & & $\%$ Volatile & $\begin{array}{c}\text { Magnetic } \\
\text { Susceptibility }\end{array}$ \\
\hline Depth & Location & Number & Site Number & Sample & $\%$ Ash & Material & $\left(\times 10^{\wedge}-6\right)$ \\
\hline 30-35 & A3 & 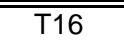 & $\bar{N} / \mathrm{A}$ & A3-31 & 98.72 & 1.28 & 29 \\
\hline $40-45$ & A3 & T16 & $\mathrm{N} / \mathrm{A}$ & A3-32 & 98.94 & 1.06 & 36 \\
\hline $50-55$ & A3 & T16 & $\mathrm{N} / \mathrm{A}$ & A3-33 & 98.63 & 1.37 & 40 \\
\hline $60-65$ & A3 & T16 & $\mathrm{N} / \mathrm{A}$ & A3-34 & 99.21 & 0.79 & 33 \\
\hline $70-75$ & A3 & T16 & $\mathrm{N} / \mathrm{A}$ & A3-35 & 99.34 & 0.66 & 28 \\
\hline $82-87$ & A3 & T16 & $\mathrm{N} / \mathrm{A}$ & A3-36 & 97.18 & 2.82 & 45 \\
\hline $93-98$ & A3 & T16 & $\mathrm{N} / \mathrm{A}$ & A3-37 & 96.41 & 3.59 & 35 \\
\hline $100-105$ & A3 & T16 & $\mathrm{N} / \mathrm{A}$ & A3-38 & 97.24 & 2.76 & 37 \\
\hline $110-115$ & A3 & T16 & $\mathrm{N} / \mathrm{A}$ & A3-39 & 97.85 & 2.15 & 29 \\
\hline $120-125$ & A3 & T16 & $\mathrm{N} / \mathrm{A}$ & A3-40 & 98.06 & 1.94 & 30 \\
\hline $15-20$ & A8 & $T 1$ & 31RD1173 & A8-1 & 96.24 & 3.76 & 53 \\
\hline $30-35$ & A8 & T1 & 31RD1173 & A8-2 & 96.18 & 3.82 & 61 \\
\hline $40-45$ & A8 & T1 & 31RD1173 & A8-3 & 97.49 & 2.51 & 63 \\
\hline $50-55$ & A8 & T1 & 31RD1173 & A8-4 & 97.50 & 2.50 & 68 \\
\hline $60-65$ & A8 & T1 & 31RD1173 & A8-5 & 97.41 & 2.59 & 41 \\
\hline $70-75$ & A8 & T1 & 31RD1173 & A8-6 & 96.49 & 3.51 & 60 \\
\hline $80-85$ & A8 & $\mathrm{T} 1$ & 31RD1173 & A8-7 & 96.16 & 3.84 & 53 \\
\hline $10-15$ & A8 & T2 & 31RD1173 & A8-8 & 95.65 & 4.35 & 69 \\
\hline $20-25$ & A8 & T2 & 31RD1173 & A8-9 & 96.12 & 3.88 & 60 \\
\hline $30-35$ & A8 & T2 & 31RD1173 & A8-10 & 98.54 & 1.46 & 37 \\
\hline $40-45$ & A8 & T2 & 31RD1173 & A8-11 & 98.15 & 1.85 & 43 \\
\hline $50-55$ & A8 & T2 & 31RD1173 & A8-12 & 98.09 & 1.91 & 50 \\
\hline $60-65$ & A8 & T2 & 31RD1173 & A8-13 & 97.84 & 2.16 & 51 \\
\hline $70-75$ & A8 & T2 & 31RD1173 & A8-14 & 97.80 & 2.20 & 56 \\
\hline $80-85$ & A8 & T2 & 31RD1173 & A8-15 & 96.93 & 3.07 & 49 \\
\hline $90-95$ & A8 & T2 & 31RD1173 & A8-16 & 96.43 & 3.57 & 43 \\
\hline $100-105$ & A8 & T2 & 31RD1173 & A8-17 & 96.68 & 3.32 & 40 \\
\hline $110-115$ & A8 & T2 & 31RD1173 & A8-18 & 96.91 & 3.09 & 39 \\
\hline $25-30$ & A8 & T5 & 31RD1173 & A8-19 & 98.41 & 1.59 & 49 \\
\hline $40-45$ & A8 & T5 & 31RD1173 & A8-20 & 97.58 & 2.42 & 36 \\
\hline $55-60$ & A8 & T5 & 31RD1173 & A8-21 & 96.53 & 3.47 & 33 \\
\hline $70-75$ & A8 & T5 & 31RD1173 & A8-22 & 93.73 & 6.27 & 24 \\
\hline $95-100$ & A8 & T5 & 31RD1173 & A8-23 & 95.66 & 4.34 & 24 \\
\hline $10-15$ & A8 & T6 & 31RD1173 & A8-24 & 93.39 & 6.61 & 62 \\
\hline $19-24$ & A8 & T6 & 31RD1173 & A8-25 & 92.95 & 7.05 & 67 \\
\hline $30-35$ & A8 & T6 & 31RD1173 & A8-26 & 92.90 & 7.10 & 38 \\
\hline $40-45$ & A8 & T6 & 31RD1173 & A8-27 & 93.37 & 6.63 & 30 \\
\hline $50-55$ & A8 & T6 & 31RD1173 & A8-28 & 94.96 & 5.04 & 32 \\
\hline $65-70$ & A8 & T6 & 31RD1173 & A8-29 & 97.02 & 2.98 & 35 \\
\hline $75-80$ & A8 & T6 & 31RD1173 & A8-30 & 96.94 & 3.06 & 32 \\
\hline $85-90$ & A8 & T6 & 31RD1173 & A8-31 & 97.16 & 2.84 & 30 \\
\hline $5-10$ & A8 & SandPit & 31RD1173 & A8-32 & 95.00 & 5.00 & 42 \\
\hline $10-15$ & A8 & SandPit & 31RD1173 & A8-33 & 96.54 & 3.46 & 49 \\
\hline $20-25$ & A8 & SandPit & 31RD1173 & A8-34 & 97.42 & 2.58 & 42 \\
\hline $30-35$ & A8 & SandPit & 31RD1173 & A8-35 & 97.88 & 2.12 & 48 \\
\hline $40-45$ & A8 & SandPit & 31RD1173 & A8-36 & 98.43 & 1.57 & 46 \\
\hline $50-55$ & A8 & SandPit & 31RD1173 & A8-37 & 97.57 & 2.43 & 42 \\
\hline $75-80$ & A8 & SandPit & 31RD1173 & A8-38 & 98.04 & 1.96 & 39 \\
\hline $85-90$ & A8 & SandPit & 31RD1173 & A8-39 & 97.82 & 2.18 & 22 \\
\hline $0-5$ & A9 & T5 & 31RD376 & A9-1 & 94.73 & 5.27 & 45 \\
\hline 10 & A9 & T5 & 31RD376 & A9-2 & 96.42 & 3.58 & 46 \\
\hline 20 & A9 & T5 & 31RD376 & A9-3 & 98.49 & 1.51 & 42 \\
\hline 30 & A9 & T5 & 31RD376 & A9-4 & 98.82 & 1.18 & 40 \\
\hline 40 & A9 & T5 & 31RD376 & A9-5 & 98.81 & 1.19 & 42 \\
\hline 50 & A9 & T5 & 31RD376 & A9-6 & 98.87 & 1.13 & 45 \\
\hline 60 & A9 & T5 & 31RD376 & A9-7 & 99.06 & 0.94 & 42 \\
\hline 70 & A9 & T5 & 31RD376 & A9-8 & 98.9 & 1.1 & 45 \\
\hline 80 & A9 & T5 & 31RD376 & A9-9 & 98.25 & 1.75 & 50 \\
\hline 90 & A9 & T5 & 31RD376 & A9-10 & 97.73 & 2.27 & 60 \\
\hline
\end{tabular}




\begin{tabular}{|c|c|c|c|c|c|c|c|}
\hline & Area & Trench & & & & \% Volatile & $\begin{array}{c}\text { Magnetic } \\
\text { Susceptibility }\end{array}$ \\
\hline Depth & Location & Number & Site Number & Sample & $\%$ Ash & Material & (x 10^-6) \\
\hline \hline 100 & A9 & T5 & 31RD376 & A9-11 & 97.21 & 2.79 & 58 \\
\hline $0-5$ & A9 & T6 & 31RD283 & A9-12 & 91.36 & 8.64 & 45 \\
\hline 15 & A9 & T6 & 31RD283 & A9-13 & 96.89 & 3.11 & 47 \\
\hline 25 & A9 & T6 & 31RD283 & A9-14 & 96.87 & 3.13 & 48 \\
\hline 35 & A9 & T6 & 31RD283 & A9-15 & 97.3 & 2.7 & 48 \\
\hline 45 & A9 & T6 & 31RD283 & A9-16 & 97.95 & 2.05 & 45 \\
\hline 55 & A9 & T6 & 31RD283 & A9-17 & 98 & 2 & 41 \\
\hline $61-63$ & A9 & T6 & 31RD283 & A9-18 & 98.26 & 1.74 & 40 \\
\hline $68-72$ & A9 & T6 & 31RD283 & A9-19 & 96.27 & 3.73 & 49 \\
\hline $75-77$ & A9 & T6 & 31RD283 & A9-20 & 97.52 & 2.48 & 48 \\
\hline $82-84$ & A9 & T6 & 31RD283 & A9-21 & 97.94 & 2.06 & 43 \\
\hline $87-89$ & A9 & T6 & 31RD283 & A9-22 & 98.41 & 1.59 & 36 \\
\hline 95 & A9 & T6 & 31RD283 & A9-23 & 98.52 & 1.48 & 40 \\
\hline $0-5$ & A9 & T12 & 31RD282 & A9-24 & 94.45 & 5.55 & 30 \\
\hline 15 & A9 & T12 & 31RD282 & A9-25 & 96.91 & 3.09 & 28 \\
\hline 25 & A9 & T12 & 31RD282 & A9-26 & 96.61 & 3.39 & 32 \\
\hline 35 & A9 & T12 & 31RD282 & A9-27 & 95.47 & 4.53 & 34 \\
\hline 45 & A9 & T12 & 31RD282 & A9-28 & 96.37 & 3.63 & 31 \\
\hline $55-59$ & A9 & T12 & 31RD282 & A9-29 & 97.42 & 2.58 & 47 \\
\hline 65 & A9 & T12 & 31RD282 & A9-30 & 97.88 & 2.12 & 60 \\
\hline 75 & A9 & T12 & 31RD282 & A9-31 & 97.87 & 2.13 & 66 \\
\hline 85 & A9 & T12 & 31RD282 & A9-32 & 98.24 & 1.76 & 62 \\
\hline 95 & A9 & T12 & 31RD282 & A9-33 & 97.87 & 2.13 & 65 \\
\hline 105 & A9 & T12 & 31RD282 & A9-34 & 97.34 & 2.66 & 88 \\
\hline 115 & A9 & T12 & 31RD282 & A9-35 & 95.6 & 4.4 & 66 \\
\hline
\end{tabular}




\section{APPENDIX VI}

Elemental and X-ray Diffraction Data 


\begin{tabular}{|c|c|c|c|c|c|c|c|c|c|c|c|c|c|c|c|c|c|c|}
\hline $\begin{array}{c}\text { Area } \\
\text { Location }\end{array}$ & $\begin{array}{l}\text { Trench } \\
\text { Number }\end{array}$ & Depth & Sample \# & $\% \mathrm{MnO}$ & $\% \mathrm{SiO} 2$ & \%Al2O3 & \%Fe2O3 & $\% \mathrm{Na} 2 \mathrm{O}$ & $\% \mathrm{MgO}$ & \%TiO2 & $\% \mathrm{CaO}$ & \%P2O5 & $\begin{array}{l}\% 14 \AA \\
\text { Clays } \\
\end{array}$ & \%Quartz & \%Muscovite & \%Albite & \%Hornblende & \%Epidote \\
\hline$\overline{\bar{A} \mathrm{~A} 2}$ & $\overline{\bar{T} 1}$ & $\overline{10}$ & 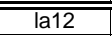 & $\overline{c 0.17}$ & $\overline{772.81}$ & 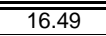 & "4.79 & 1.05 & $\overline{0.75}$ & 2.02 & 2.29 & $\overline{0.21}$ & $\overline{c 1.5}$ & $\overline{770.5}$ & 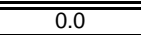 & 13.7 & 2.4 & 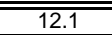 \\
\hline A2 & T1 & 20 & la13 & 0.17 & 73.87 & 15.97 & 4.32 & 1.03 & 0.70 & 2.10 & 2.28 & 0.20 & 1.3 & 66.3 & 1.4 & 16.0 & 2.4 & 12.9 \\
\hline A2 & $\mathrm{T} 1$ & 30 & la14 & 0.16 & 74.47 & 15.58 & 4.18 & 1.01 & 0.67 & 2.13 & 2.27 & 0.15 & 2.7 & 67.4 & 0.0 & 13.1 & 2.6 & 14.4 \\
\hline A2 & T1 & 40 & la15 & 0.17 & 73.94 & 15.87 & 4.36 & 1.06 & 0.65 & 2.15 & 2.29 & 0.14 & 2.4 & 68.5 & 0.0 & 14.8 & 2.6 & 12.0 \\
\hline A2 & $\mathrm{T} 1$ & 50 & la16 & 0.16 & 74.33 & 15.62 & 4.16 & 1.14 & 0.66 & 2.06 & 2.36 & 0.13 & 0.8 & 67.2 & 1.2 & 17.1 & 2.3 & 11.7 \\
\hline A2 & $\mathrm{T} 1$ & 60 & la17 & 0.16 & 74.55 & 15.56 & 3.96 & 1.20 & 0.64 & 1.98 & 2.44 & 0.13 & 1.3 & 65.4 & 0.0 & 18.9 & 3.0 & 11.7 \\
\hline A2 & T1 & 70 & la18 & 0.15 & 76.33 & 14.93 & 2.97 & 1.37 & 0.57 & 1.76 & 2.47 & 0.13 & 1.7 & 69.5 & 0.0 & 15.7 & 2.0 & 11.2 \\
\hline A2 & T1 & 80 & la19 & 0.18 & 74.34 & 15.86 & 3.68 & 1.29 & 0.68 & 1.90 & 2.58 & 0.15 & 1.7 & 64.9 & 0.0 & 20.5 & 2.0 & 11.1 \\
\hline A2 & $\mathrm{T} 1$ & 100 & la20 & 0.21 & 73.85 & 15.61 & 3.34 & 1.81 & 0.82 & 1.67 & 3.22 & 0.17 & 0.4 & 66.7 & 0.0 & 18.8 & 2.5 & 12.0 \\
\hline A2 & T1 & 120 & la21 & 0.19 & 75.08 & 14.88 & 2.76 & 2.05 & 0.81 & 1.48 & 3.30 & 0.16 & 0.6 & 59.1 & 0.0 & 24.7 & 2.8 & 13.0 \\
\hline A2 & $\mathrm{T7}$ & 20 & la22 & 0.13 & 77.53 & 14.06 & 2.25 & 1.44 & 0.58 & 1.64 & 2.60 & 0.45 & 0.0 & 71.5 & 0.0 & 16.7 & 1.6 & 10.4 \\
\hline A2 & $\mathrm{T7}$ & 40 & la23 & 0.14 & 78.78 & 13.47 & 1.88 & 1.52 & 0.57 & 1.49 & 2.61 & 0.24 & 0.0 & 68.7 & 0.0 & 17.9 & 2.1 & 11.7 \\
\hline A2 & T7 & 90 & la24 & 0.19 & 76.26 & 14.32 & 2.62 & 1.75 & 0.74 & 1.74 & 2.89 & 0.18 & 1.4 & 66.6 & 0.0 & 16.5 & 2.3 & 13.4 \\
\hline A3 & $\mathrm{T} 13$ & $46-48$ & la25 & 0.15 & 76.47 & 14.33 & 1.74 & 2.15 & 0.85 & 1.36 & 3.05 & 0.16 & 2.7 & 57.0 & 0.0 & 29.1 & 3.1 & 8.4 \\
\hline A3 & T13 & $125-130$ & la26 & 0.12 & 67.50 & 20.99 & 5.10 & 0.94 & 1.41 & 1.67 & 1.83 & 0.09 & 2.3 & 56.3 & 3.8 & 18.9 & 3.2 & 16.0 \\
\hline A3 & T16 & $20-25$ & la27 & 0.06 & 81.22 & 12.90 & 0.55 & 1.74 & 0.49 & 1.02 & 2.17 & 0.33 & 0.7 & 68.0 & 0.0 & 22.1 & 2.3 & 6.9 \\
\hline A3 & T16 & $30-35$ & la28 & 0.06 & 81.56 & 12.79 & 0.45 & 1.75 & 0.49 & 1.01 & 2.14 & 0.25 & 0.0 & 71.4 & 0.0 & 21.9 & 1.5 & 5.5 \\
\hline A3 & T16 & $40-45$ & la29 & 0.08 & 80.21 & 13.59 & 0.53 & 2.20 & 0.53 & 0.80 & 2.37 & 0.17 & 1.8 & 57.9 & 0.0 & 34.0 & 2.2 & 4.4 \\
\hline A3 & T16 & $50-55$ & la30 & 0.11 & 77.06 & 15.00 & 1.36 & 2.15 & 0.70 & 1.11 & 2.68 & 0.17 & 1.9 & 62.2 & 0.0 & 24.4 & 2.6 & 9.1 \\
\hline A3 & T16 & $60-65$ & la31 & 0.07 & 81.61 & 12.68 & 0.16 & 2.23 & 0.48 & 0.73 & 2.40 & 0.14 & 0.4 & 65.3 & 0.0 & 27.6 & 1.4 & 5.4 \\
\hline A3 & T16 & $70-75$ & la32 & 0.08 & 83.85 & 11.36 & 0.00 & 1.92 & 0.39 & 0.73 & 2.14 & 0.14 & 0.8 & 70.3 & 0.0 & 24.2 & 1.6 & 3.3 \\
\hline A3 & $\mathrm{T} 16$ & $82-87$ & la33 & 0.23 & 72.74 & 15.88 & 3.23 & 1.9 & 1.09 & 1.69 & 3.28 & 0.18 & 2.0 & 58.5 & 0.0 & 20.2 & 3.6 & 15.8 \\
\hline A3 & T16 & $93-98$ & la34 & 0.26 & 72.17 & 16.22 & 3.29 & 1.95 & 1.17 & 1.67 & 3.30 & 0.19 & 2.2 & 59.0 & 0.0 & 23.0 & 3.2 & 12.9 \\
\hline A3 & T16 & $100-105$ & la35 & 0.19 & 72.10 & 16.36 & 3.40 & 1.92 & 1.24 & 1.75 & 3.14 & 0.12 & 2.8 & 57.1 & 0.0 & 21.8 & 3.4 & 15.5 \\
\hline A3 & T16 & $110-115$ & la36 & 0.17 & 72.34 & 16.24 & 3.31 & 1.92 & 1.27 & 1.72 & 3.16 & 0.09 & 1.9 & 58.0 & 1.9 & 21.1 & 2.9 & 14.5 \\
\hline A8 & T2 & $10-15$ & la1 & 0.17 & 70.22 & 19.26 & 5.97 & 0.51 & 0.52 & 2.32 & 1.37 & 0.21 & 1.2 & 74.6 & 0.0 & 10.5 & 2.7 & 11.3 \\
\hline A8 & T2 & $20-25$ & la2 & 0.17 & 72.76 & 17.91 & 4.96 & 0.62 & 0.46 & 2.05 & 1.42 & 0.21 & 2.3 & 72.8 & 0.0 & 11.1 & 2.4 & 11.6 \\
\hline A8 & T2 & $30-35$ & la3 & 0.07 & 86.79 & 11.95 & 0.00 & 0.66 & 0.06 & 0.39 & 1.04 & 0.17 & 0.3 & 85.0 & 0.0 & 9.0 & 0.0 & 5.6 \\
\hline A8 & T2 & $40-45$ & la4 & 0.14 & 82.13 & 13.29 & 0.95 & 0.96 & 0.32 & 1.03 & 1.68 & 0.17 & 0.0 & 79.1 & 0.0 & 14.1 & 1.1 & 6.1 \\
\hline A8 & T2 & $50-55$ & la5 & 0.14 & 78.83 & 13.53 & 1.88 & 1.45 & 0.56 & 1.58 & 2.47 & 0.13 & 1.1 & 65.3 & 0.0 & 16.8 & 2.0 & 15.1 \\
\hline A8 & T2 & $60-65$ & la6 & 0.12 & 77.92 & 14.47 & 2.12 & 1.31 & 0.55 & 1.62 & 2.32 & 0.11 & 0.7 & 70.2 & 0.0 & 12.3 & 2.2 & 14.8 \\
\hline A8 & T2 & $70-75$ & la7 & 0.12 & 75.47 & 17.18 & 2.62 & 0.97 & 0.57 & 1.58 & 1.95 & 0.10 & 2.0 & 69.2 & 0.0 & 14.5 & 1.6 & 13.0 \\
\hline A8 & T2 & $80-85$ & la8 & 0.07 & 70.46 & 22.24 & 3.79 & 0.63 & 0.47 & 1.39 & 1.44 & 0.09 & 0.8 & 71.3 & 0.0 & 13.6 & 1.9 & 12.7 \\
\hline A8 & T2 & $90-95$ & la9 & 0.05 & 68.54 & 24.54 & 4.15 & 0.54 & 0.37 & 1.18 & 1.22 & 0.09 & 1.7 & 72.6 & 0.0 & 14.5 & 0.0 & 11.4 \\
\hline A8 & T2 & $100-105$ & la10 & 0.06 & 68.74 & 24.31 & 3.83 & 0.69 & 0.40 & 1.15 & 1.40 & 0.10 & 2.8 & 62.8 & 0.0 & 18.6 & 0.0 & 16.0 \\
\hline A8 & T2 & $110-115$ & la11 & 0.06 & 69.15 & 24.13 & 3.56 & 0.72 & 0.43 & 1.06 & 1.45 & 0.12 & 1.4 & 70.2 & 0.0 & 16.9 & 0.0 & 11.7 \\
\hline A9 & T5 & 10 & la37 & 0.14 & 71.82 & 17.46 & 3.86 & 1.42 & 1.11 & 1.68 & 2.54 & 0.17 & 1.2 & 58.5 & 4.0 & 18.7 & 3.2 & 14.8 \\
\hline A9 & T5 & 90 & la38 & 0.11 & 70.23 & 19.21 & 3.46 & 1.55 & 1.19 & 1.71 & 2.64 & 0.14 & 2.0 & 57.6 & 0.0 & 20.8 & 3.7 & 16.2 \\
\hline A9 & T5 & 100 & la39 & 0.09 & 70.21 & 19.40 & 3.70 & 1.46 & 1.19 & 1.65 & 2.47 & 0.11 & 2.0 & 56.1 & 0.0 & 26.6 & 2.1 & 13.1 \\
\hline \multirow[t]{6}{*}{ A9 } & T6 & $82-84$ & la40 & 0.14 & 76.75 & 14.46 & 1.72 & 1.76 & 0.84 & 1.63 & 2.67 & 0.13 & 0.8 & 69.6 & 0.0 & 17.7 & 2.2 & 10.0 \\
\hline & & & & & & & & & & & & & & & & & & \\
\hline & & & Average & 0.14 & 75.12 & 16.25 & 2.87 & 1.39 & 0.70 & 1.54 & 2.33 & 0.16 & 1.4 & 66.2 & 0.3 & $\begin{array}{l}18.7 \\
524\end{array}$ & 2.2 & 11.5 \\
\hline & & & STD & 0.05 & 4.45 & 3.25 & 1.51 & 0.51 & 0.30 & 0.44 & 0.60 & 0.07 & 0.83 & 6.52 & 0.92 & 5.24 & 0.93 & 3.40 \\
\hline & & & MAX & 0.21 & 86.79 & 24.54 & 5.97 & 2.23 & 1.41 & 2.32 & 3.30 & 0.45 & 2.8 & 85.0 & 3.8 & 34.0 & 3.7 & 16.2 \\
\hline & & & MIN & 0.05 & 67.50 & 11.36 & 0.00 & 0.51 & 0.06 & 0.39 & 1.04 & 0.09 & 0.0 & 56.1 & 0.0 & 9.0 & 0.0 & 3.3 \\
\hline
\end{tabular}




\section{APPENDIX VII}

\section{Bivariate Plots \& r values}

Explanation:

Relationships between particle size and percent oxide and particle size and minerology are shown in the following bivariate plots. Figures 12, 13, 14 and 15 were generated from the statistical $r$-values from these bivariate plots in order to help illustrate the variations in magnetic susceptibility in response to particle-size for historic and prehistoric populations. 


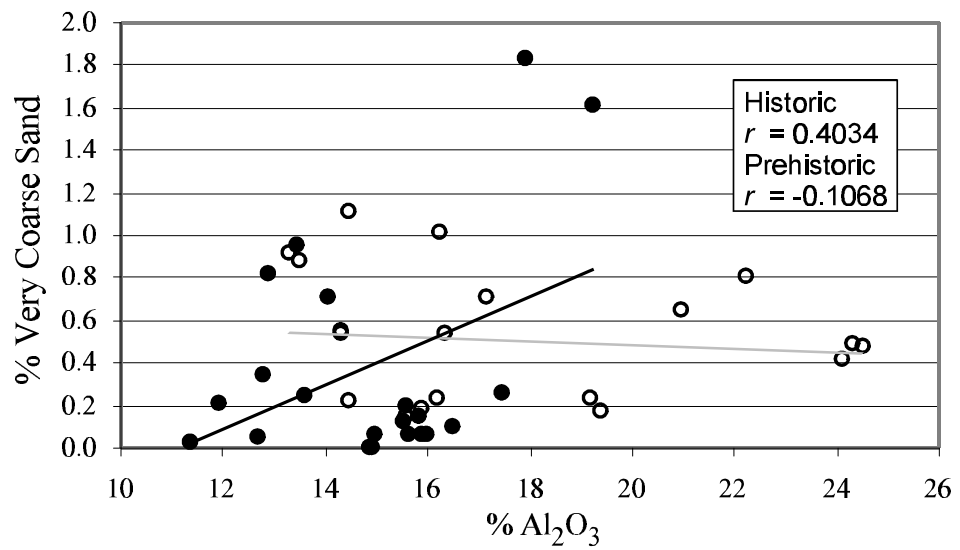

Historic - Prehistoric $0-$

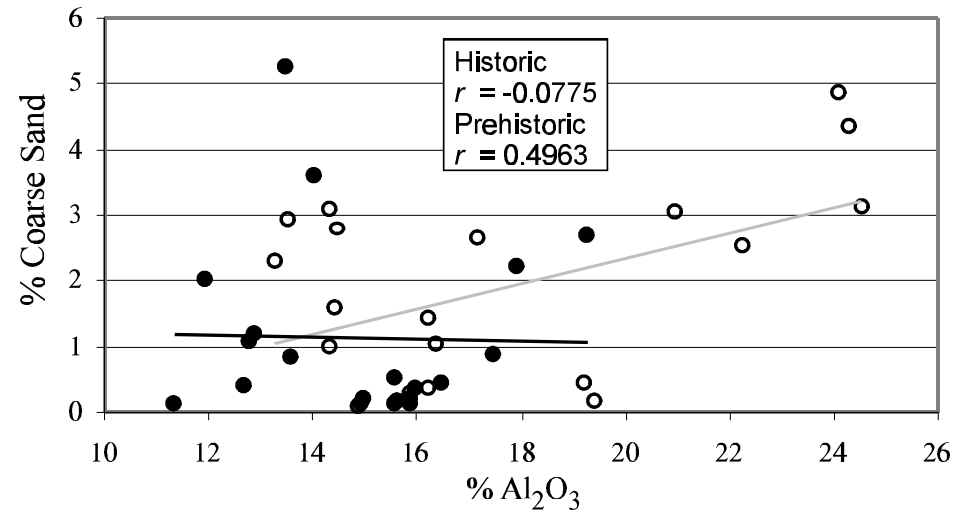

Historic $\bigcirc-$ Prehistoric $0-$

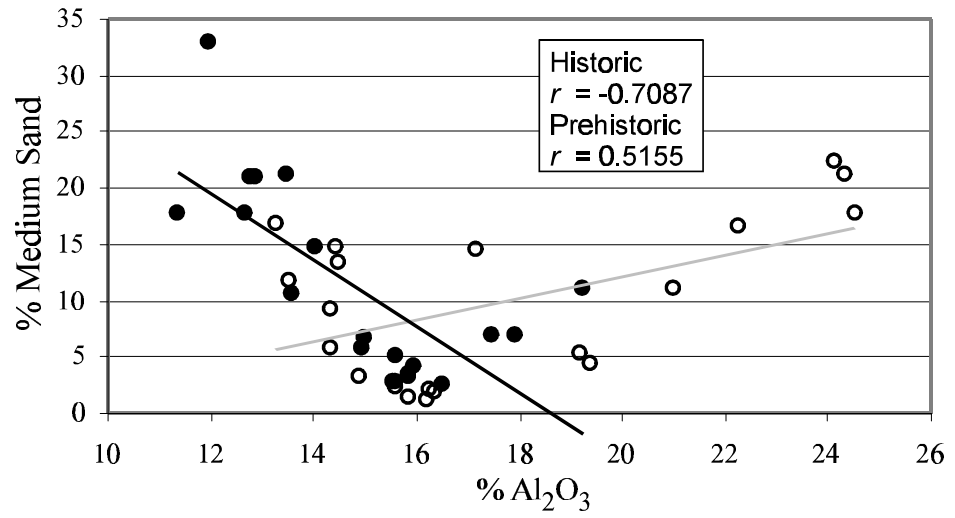

Historic $\bullet-$ Prehistoric $0-$ 


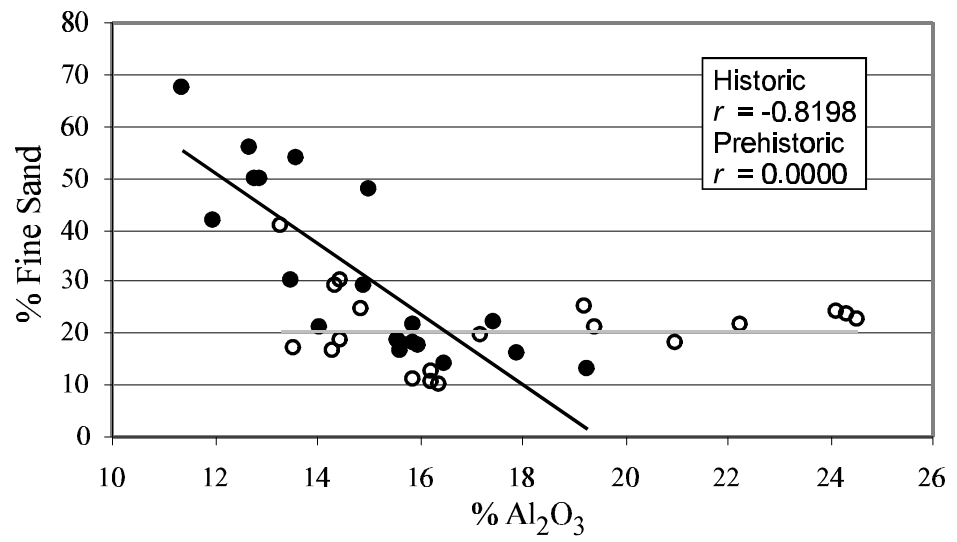

Historic $\bullet-$ Prehistoric $0-$

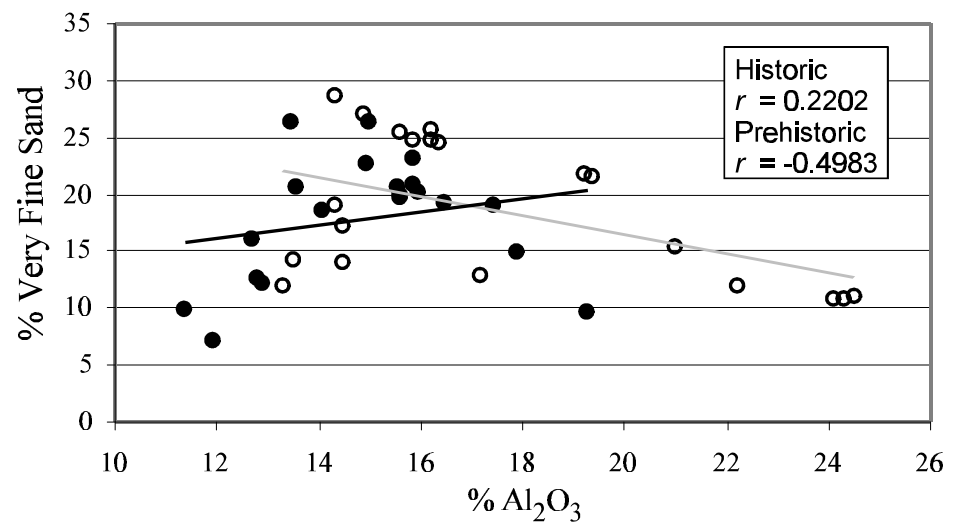

Historic $\bullet-$ Prehistoric $0-$

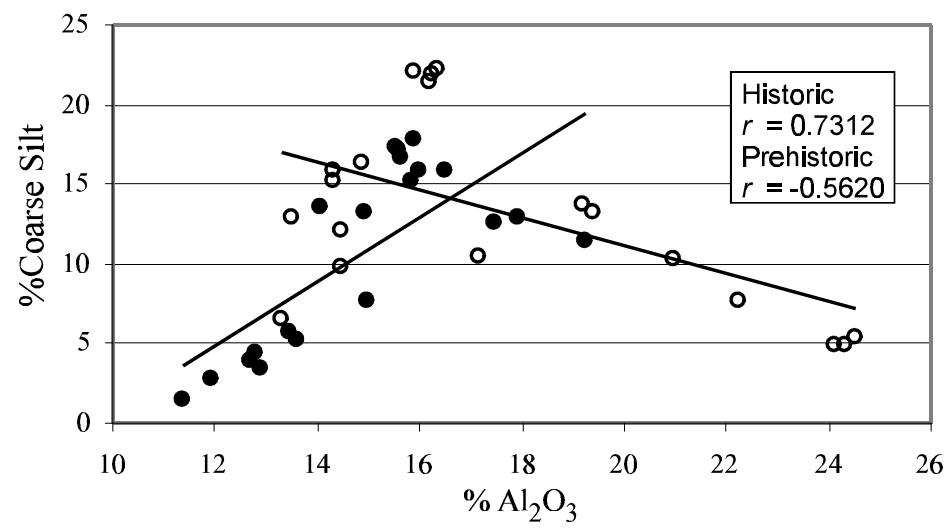

Historic $\bullet-$ Prehistoric $0-$ 


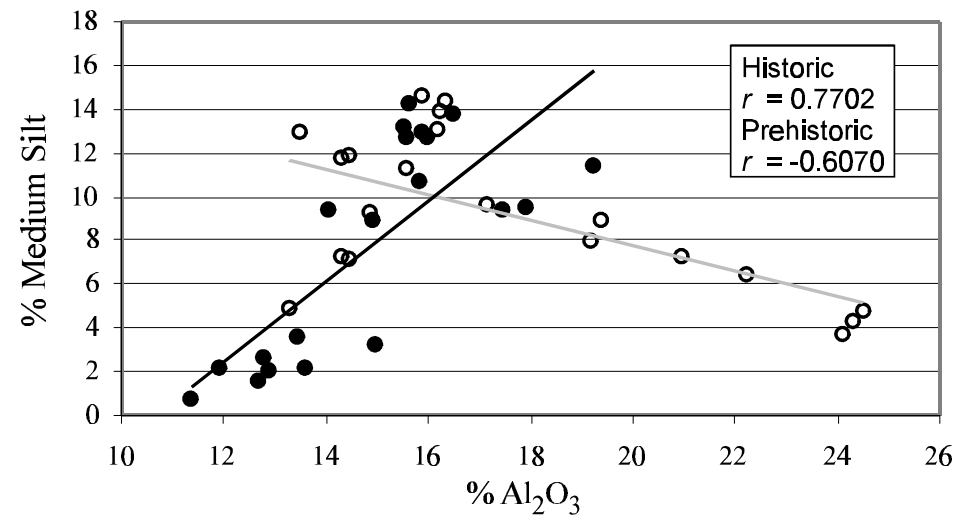

Historic $\bullet-$ Prehistoric $0-$

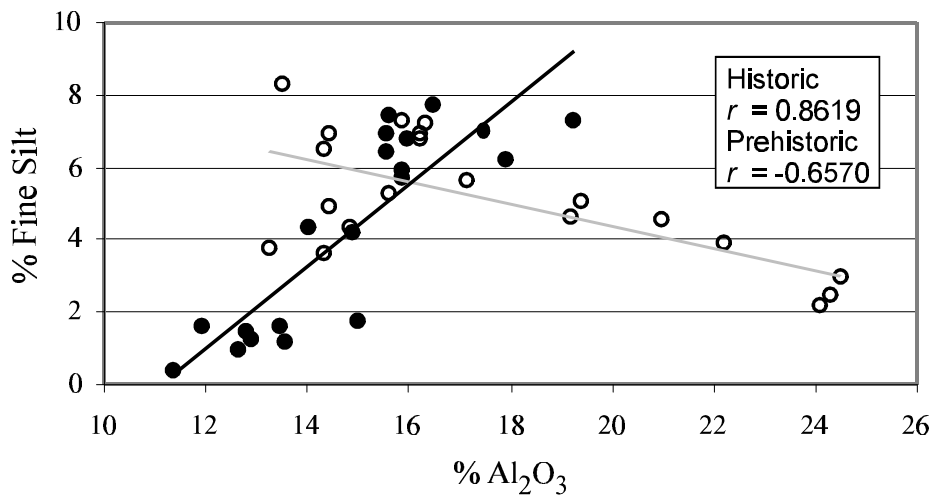

Historic $\bullet-$ Prehistoric $0-$

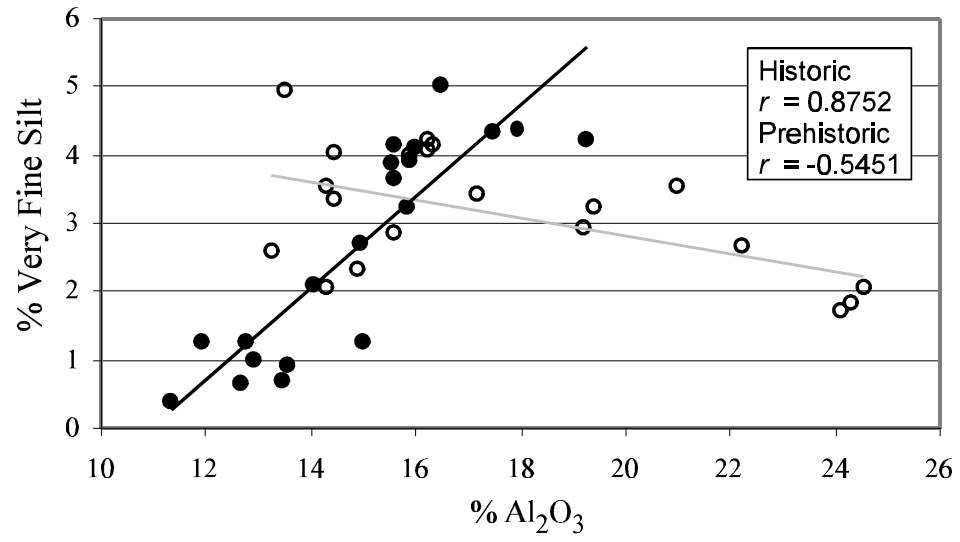

Historic $\bullet-$ Prehistoric $0-$ 


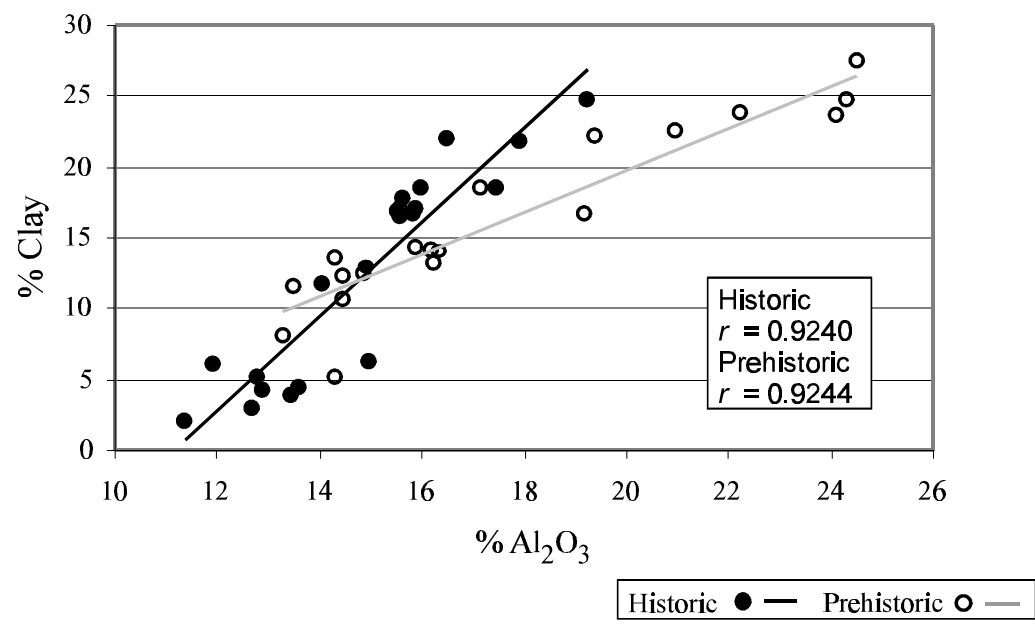



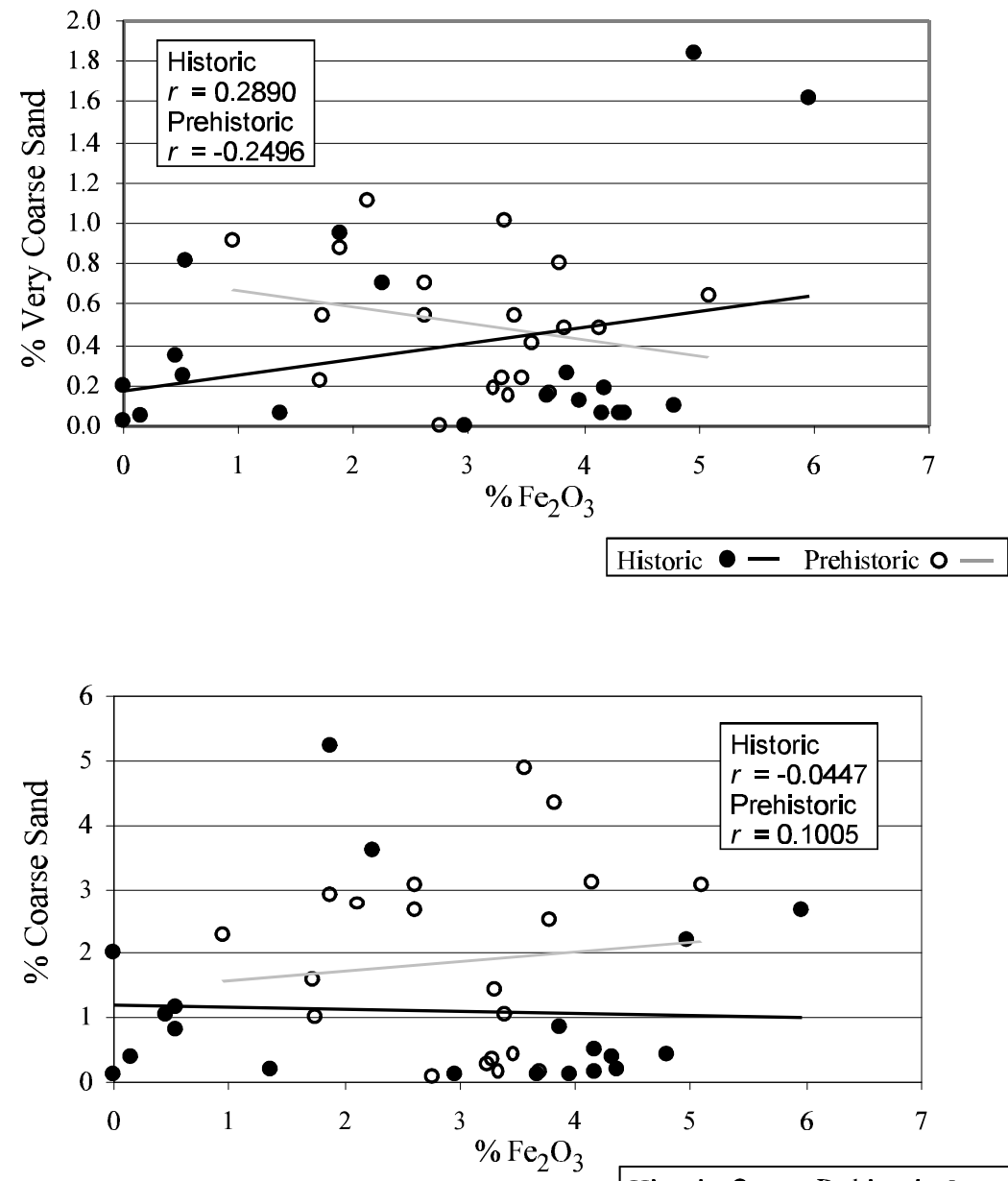

Historic $\bullet-$ Prehistoric $0-$

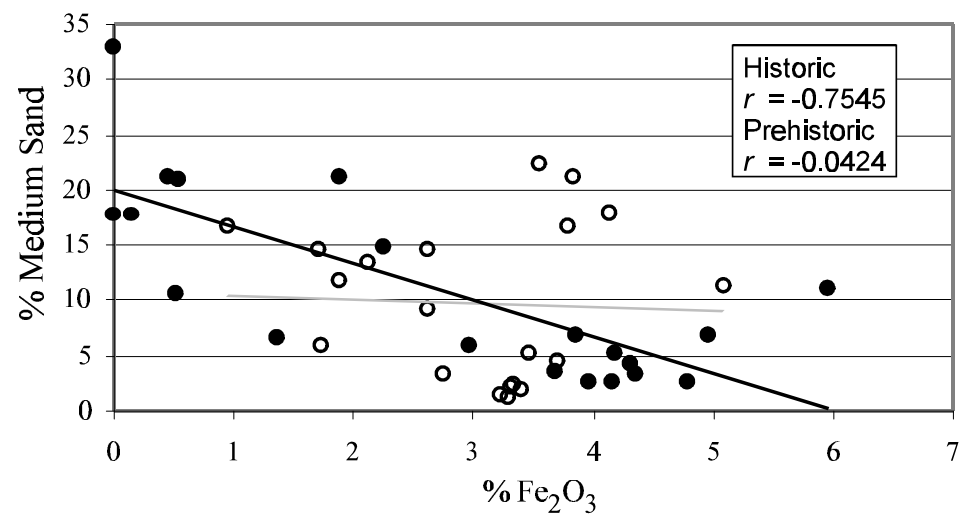

Historic $\bullet-$ Prehistoric $0-$ 


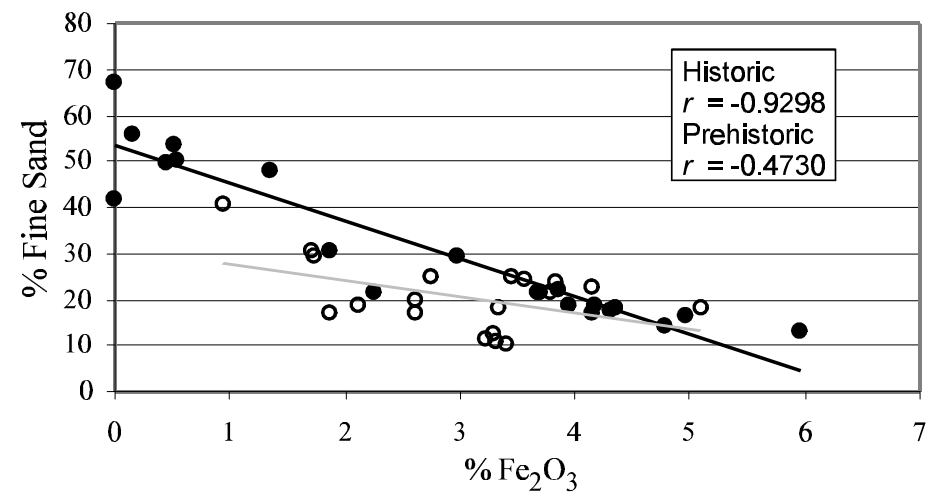

Historic $\bullet-$ Prehistoric $0-$

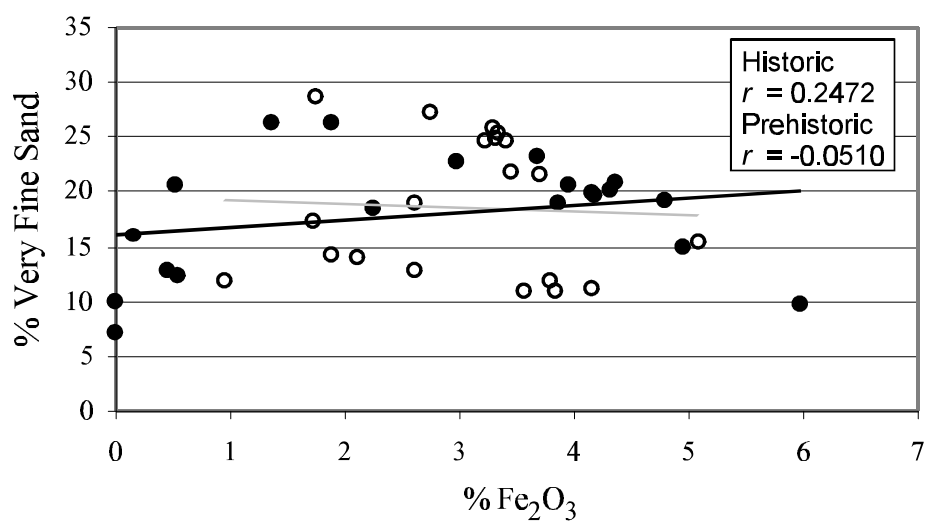

Historic $\bullet-$ Prehistoric $0-$

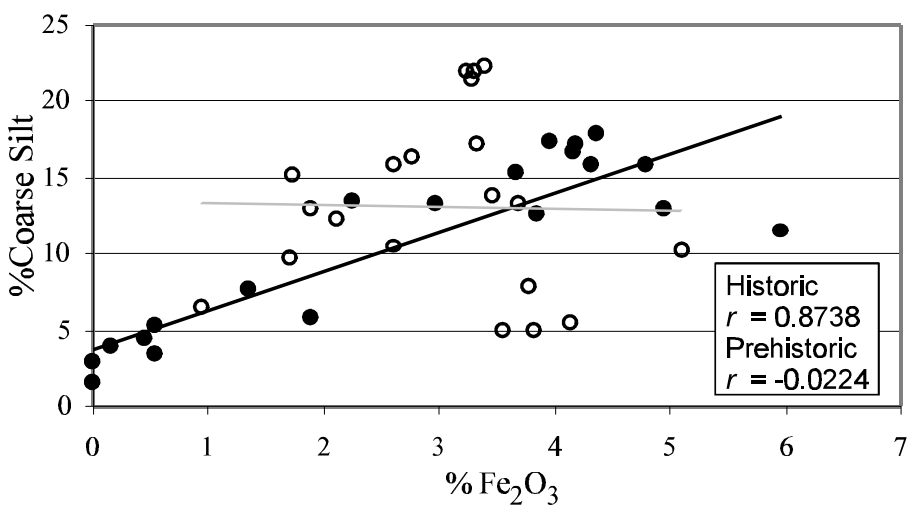

Historic $\bullet-$ Prehistoric $0-$ 


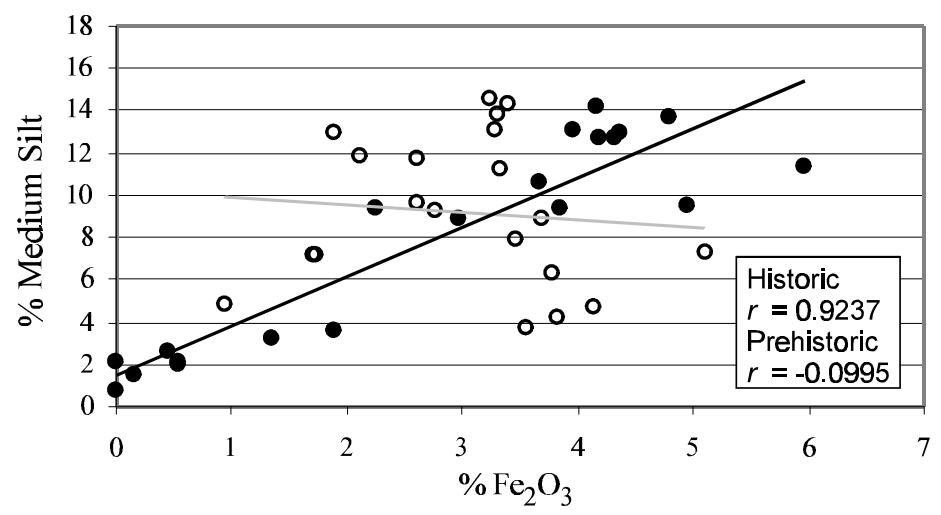

Historic $\bullet-$ Prehistoric $0-$

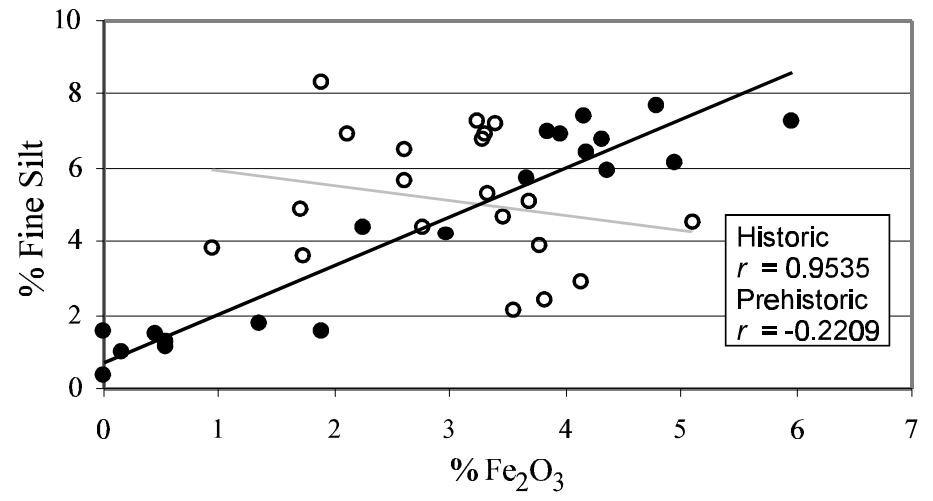

Historic $\bullet-$ Prehistoric $0-$

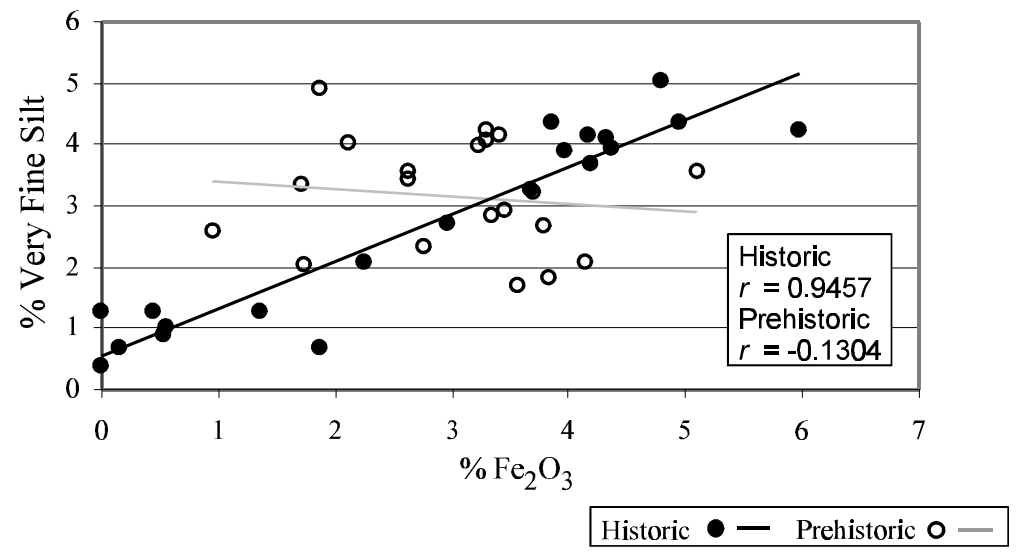




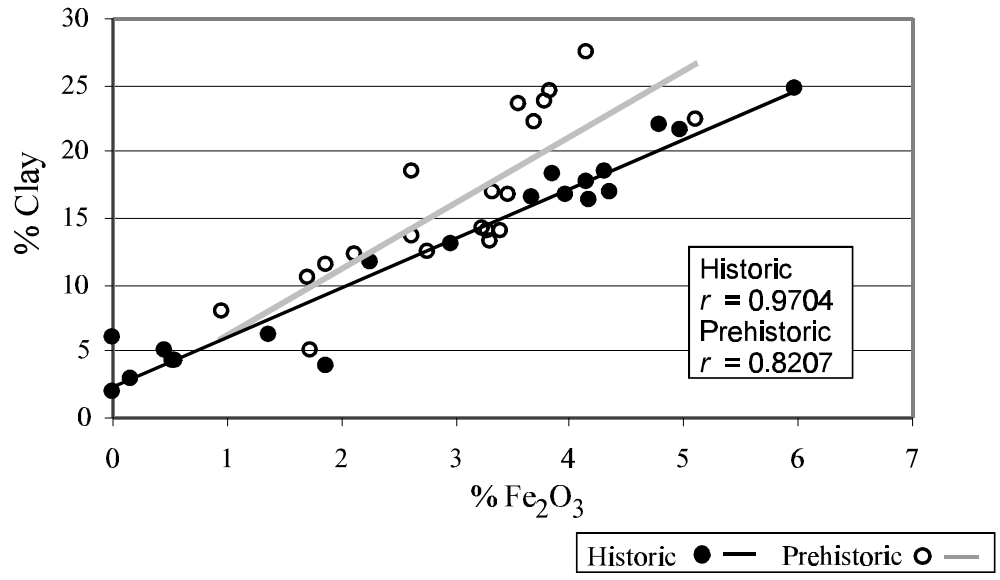

104 

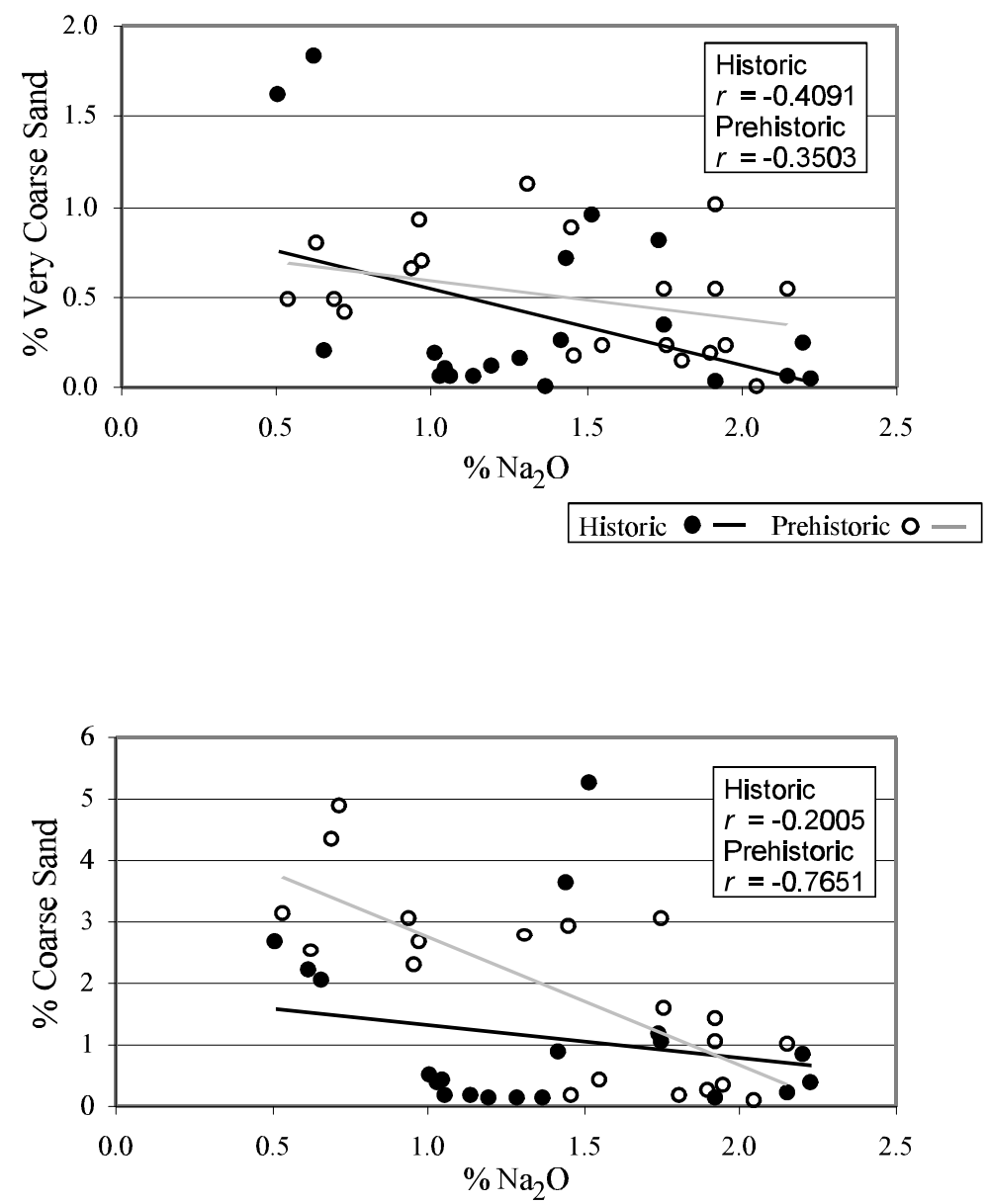

Historic $\bullet-$ Prehistoric $0-$

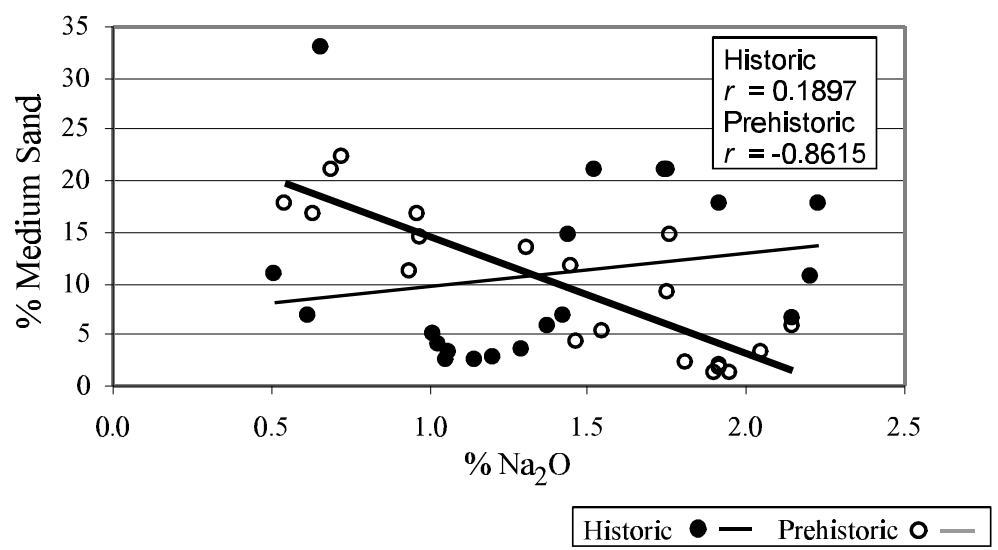




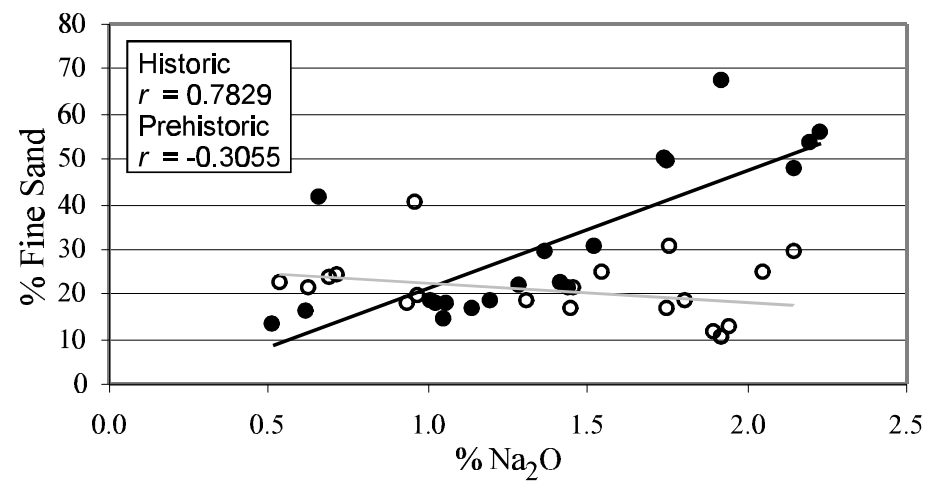

Historic $\bullet-$ Prehistoric $0-$

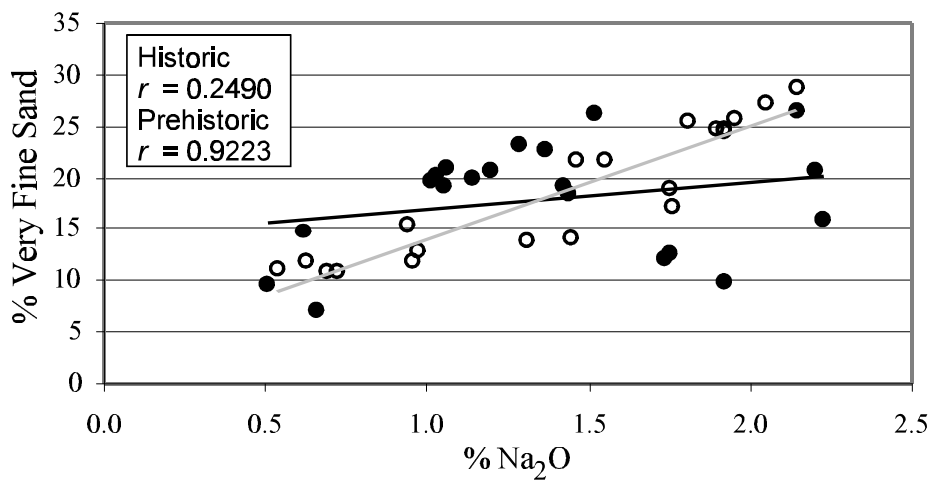

Historic $\bullet-$ Prehistoric $0-$

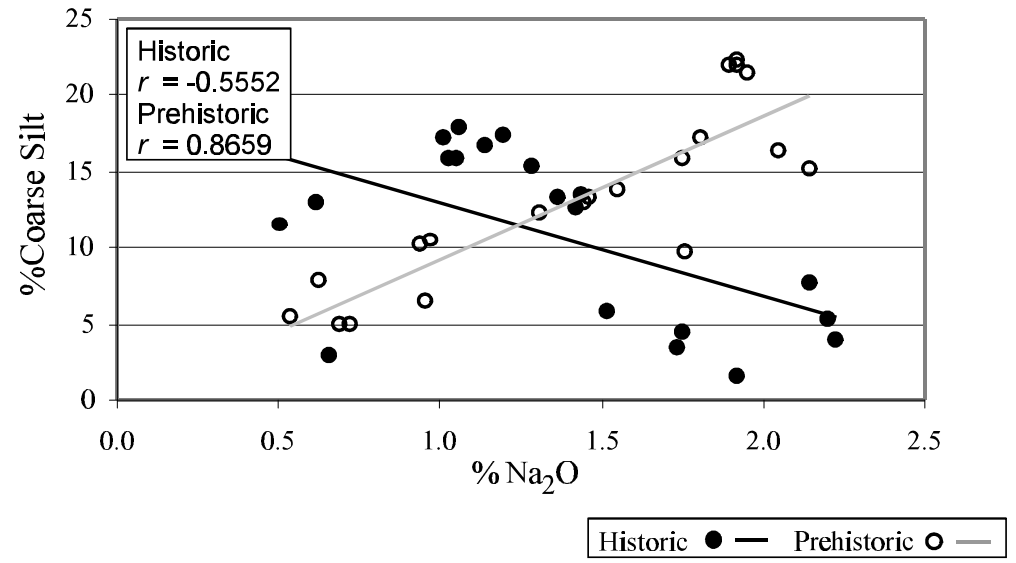



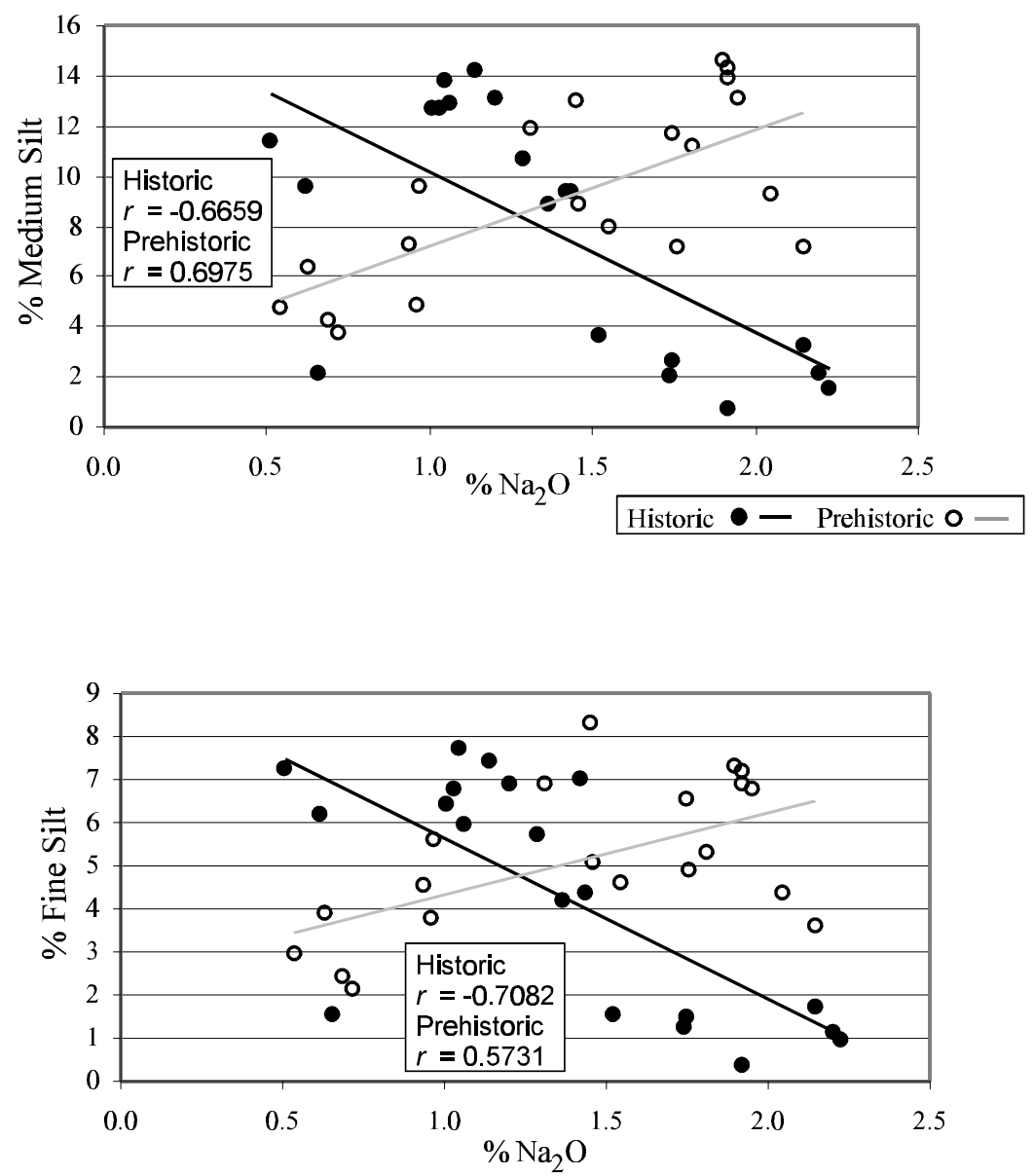

Historic $\bullet-$ Prehistoric $0-$

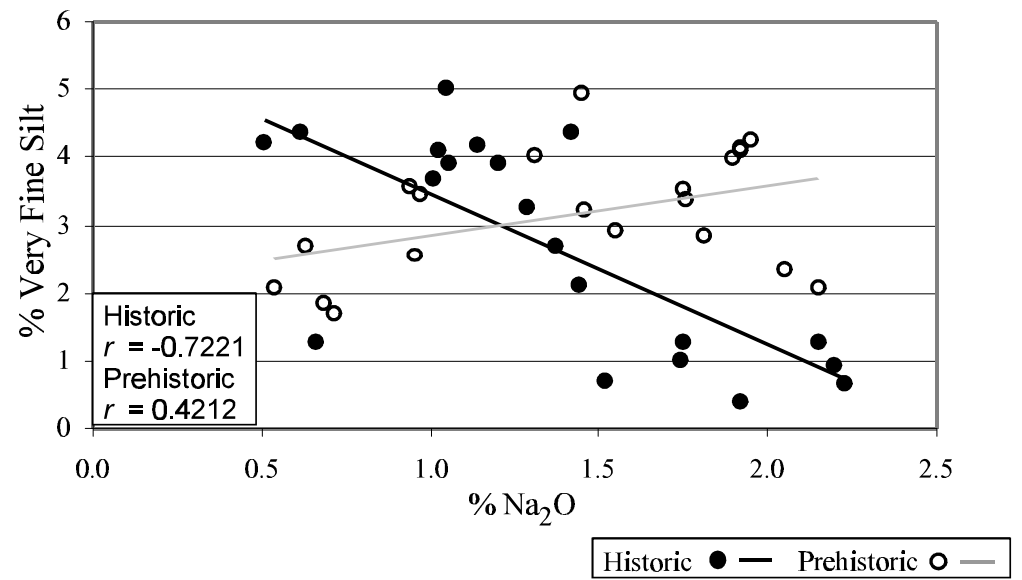




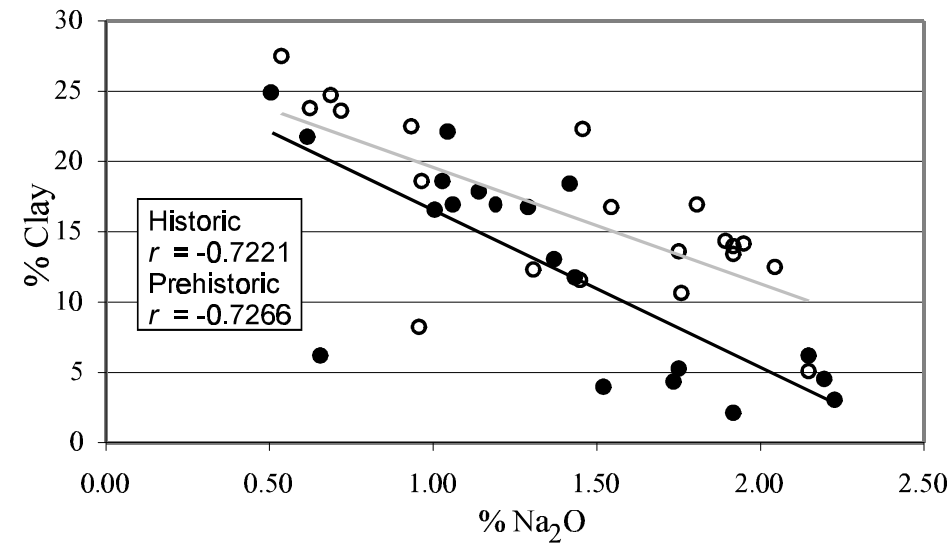

Historic $\bullet-$ Prehistoric $0-$ 

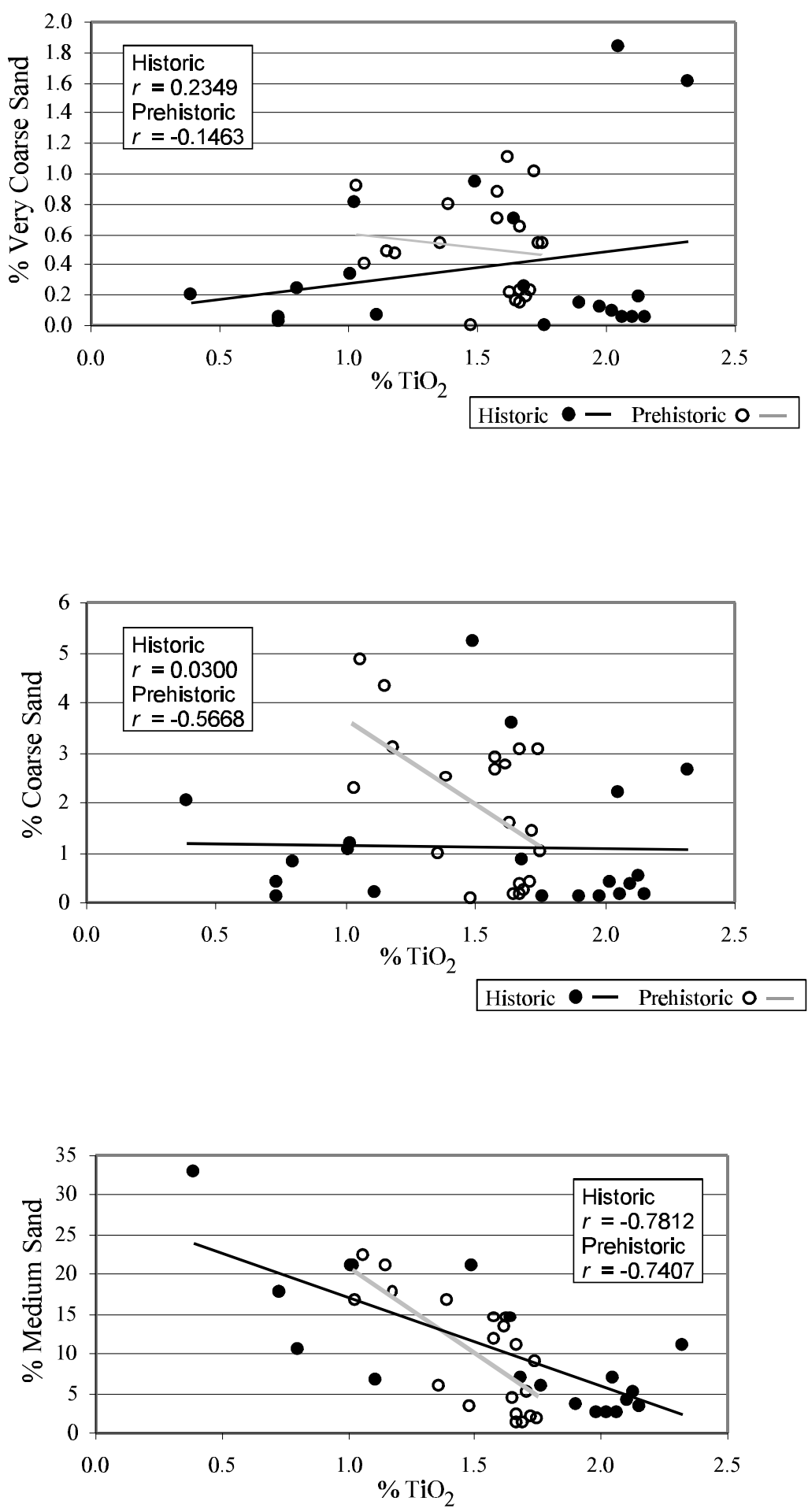

Historic $\bullet-$ Prehistoric $0-$ 

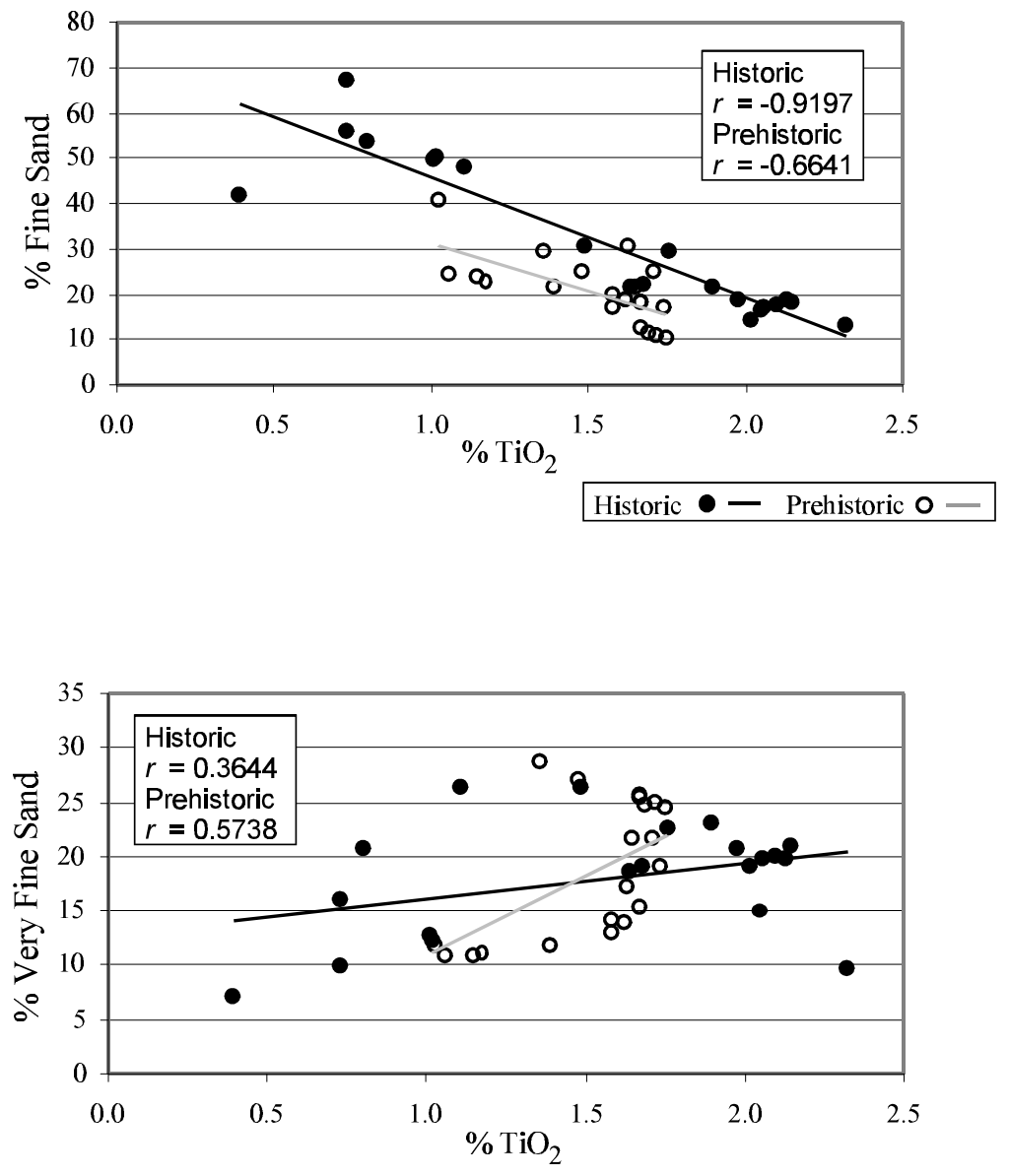

Historic $\bullet-$ Prehistoric $0-$

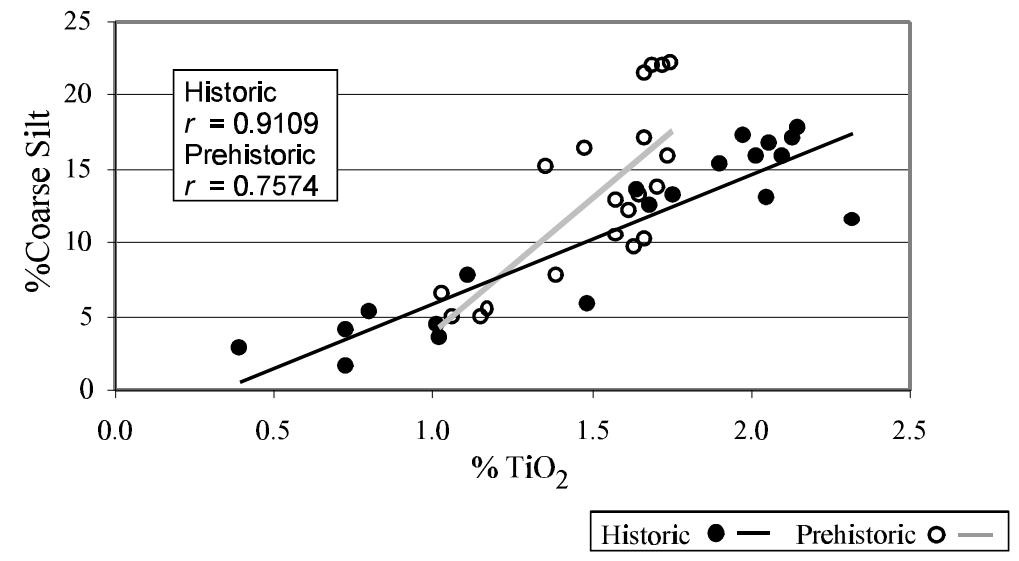



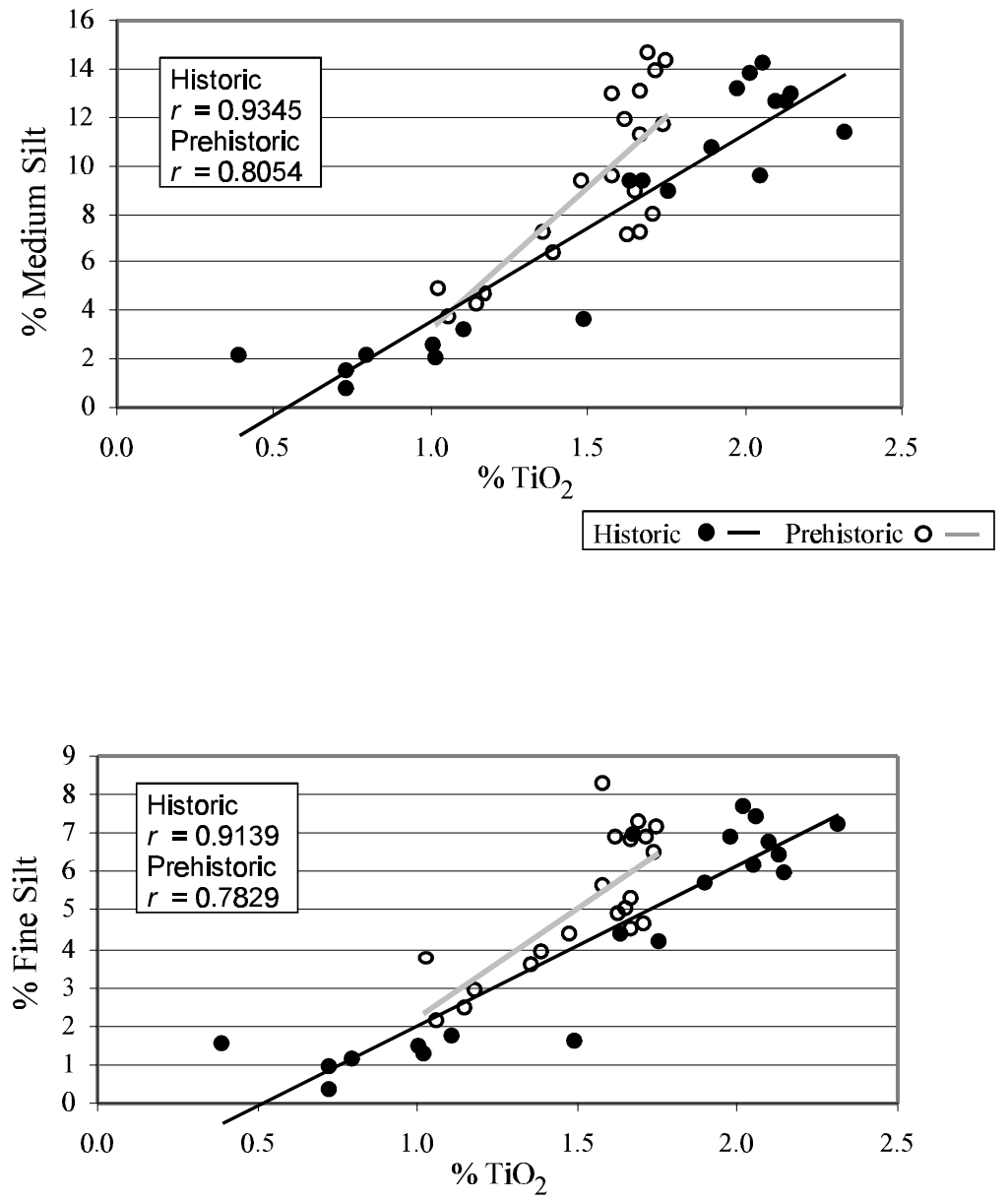

Historic $\bullet-$ Prehistoric $0-$

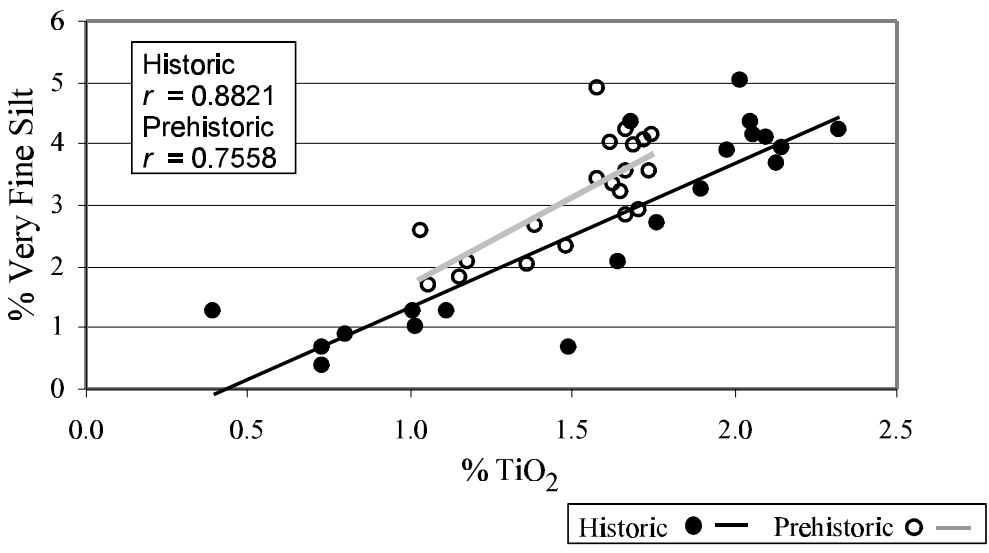




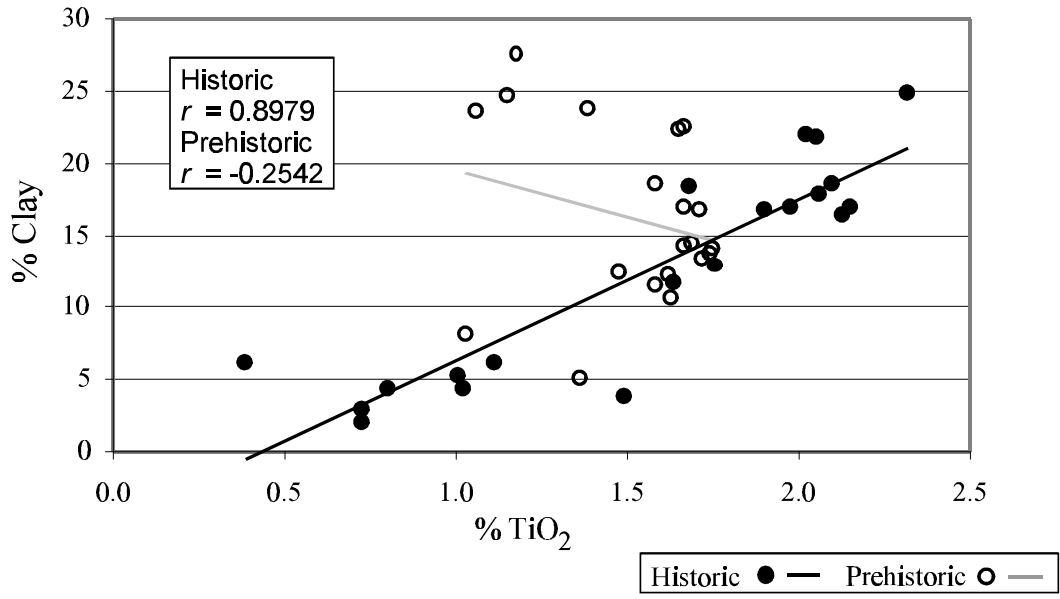



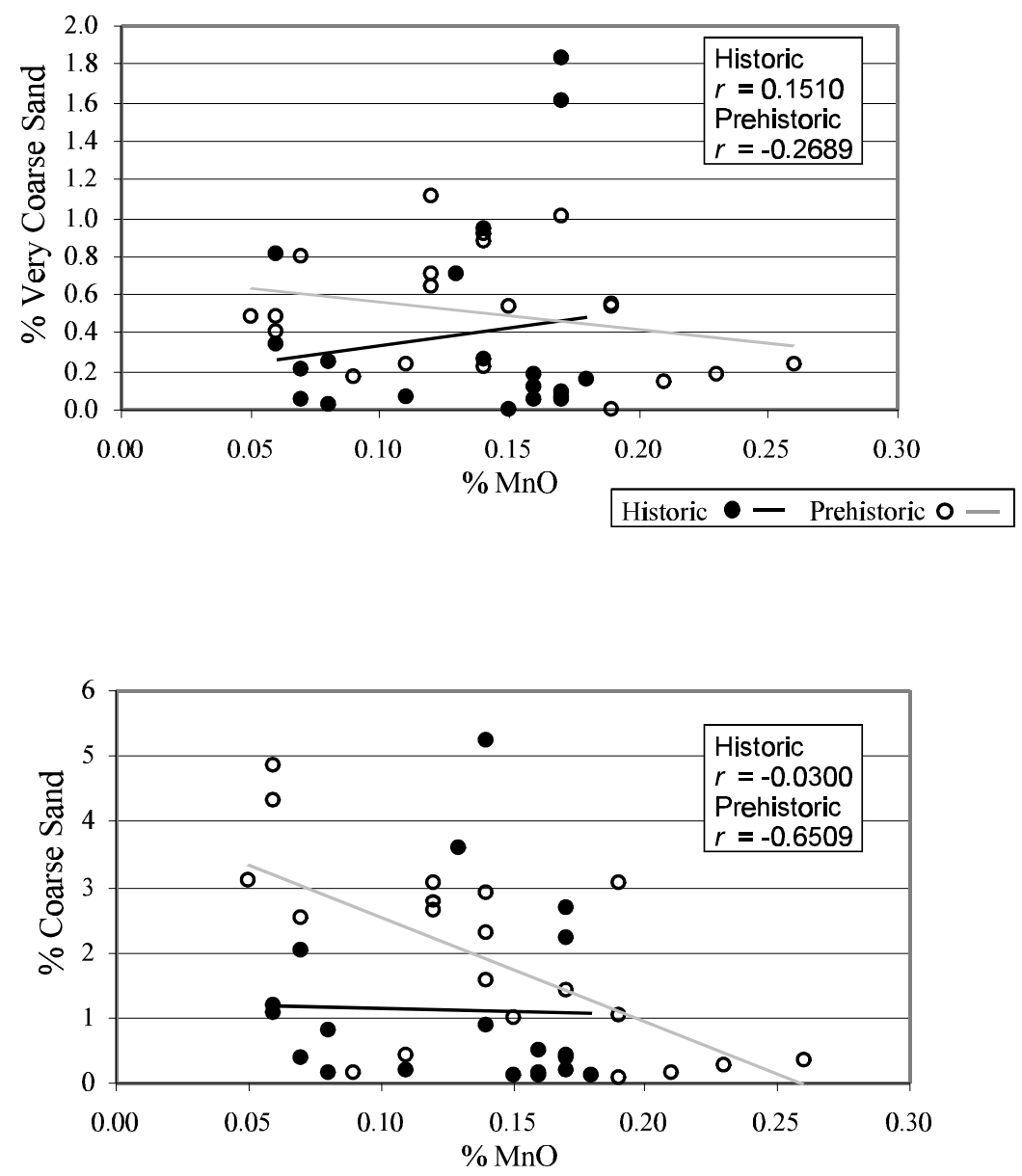

Historic $\bullet-$ Prehistoric $0-$

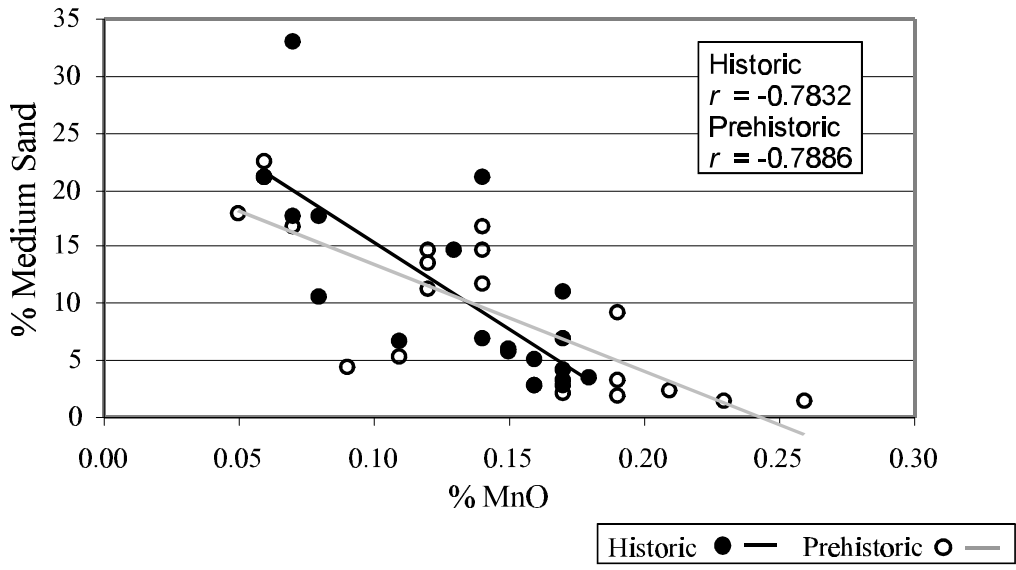



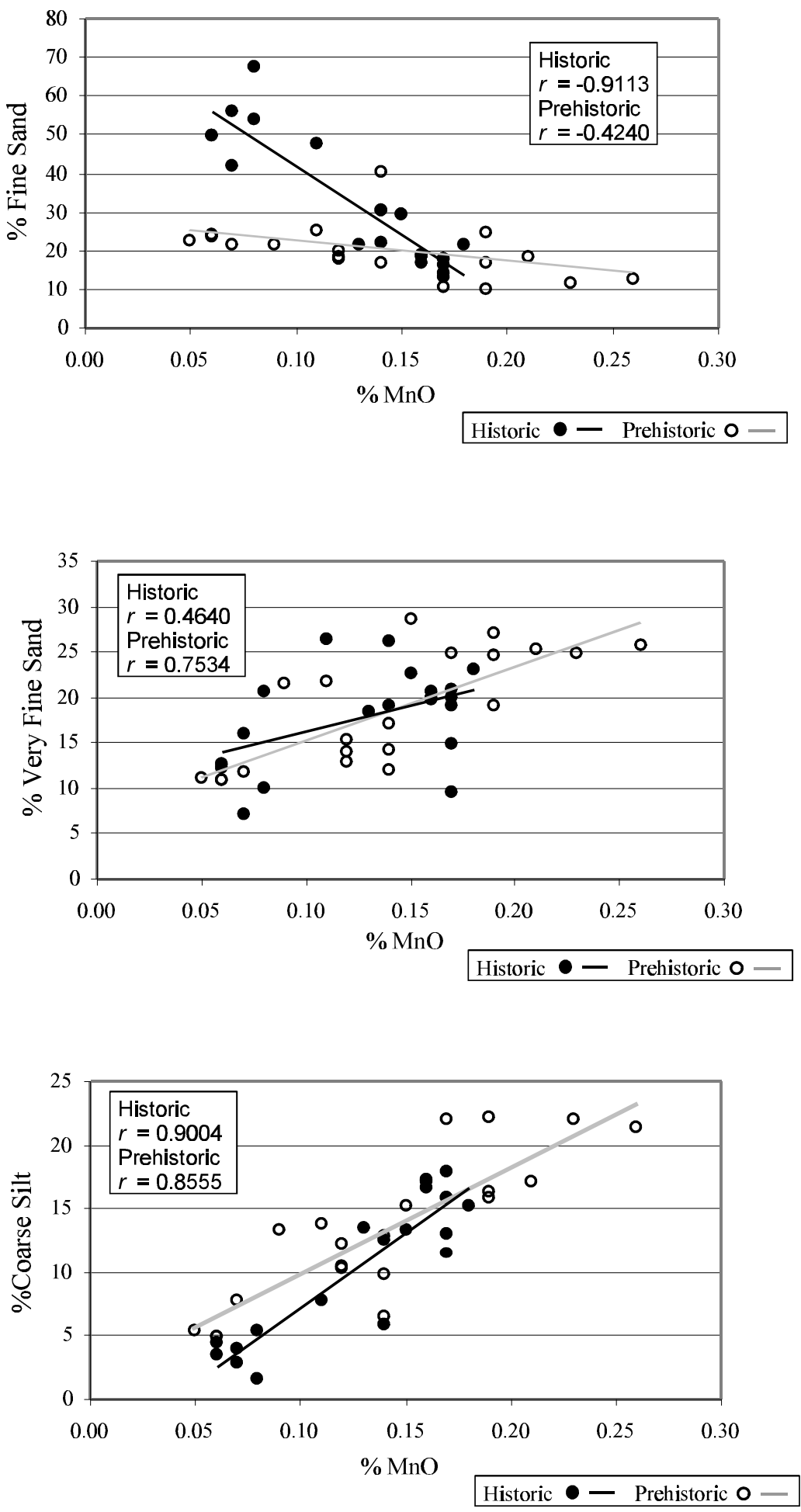

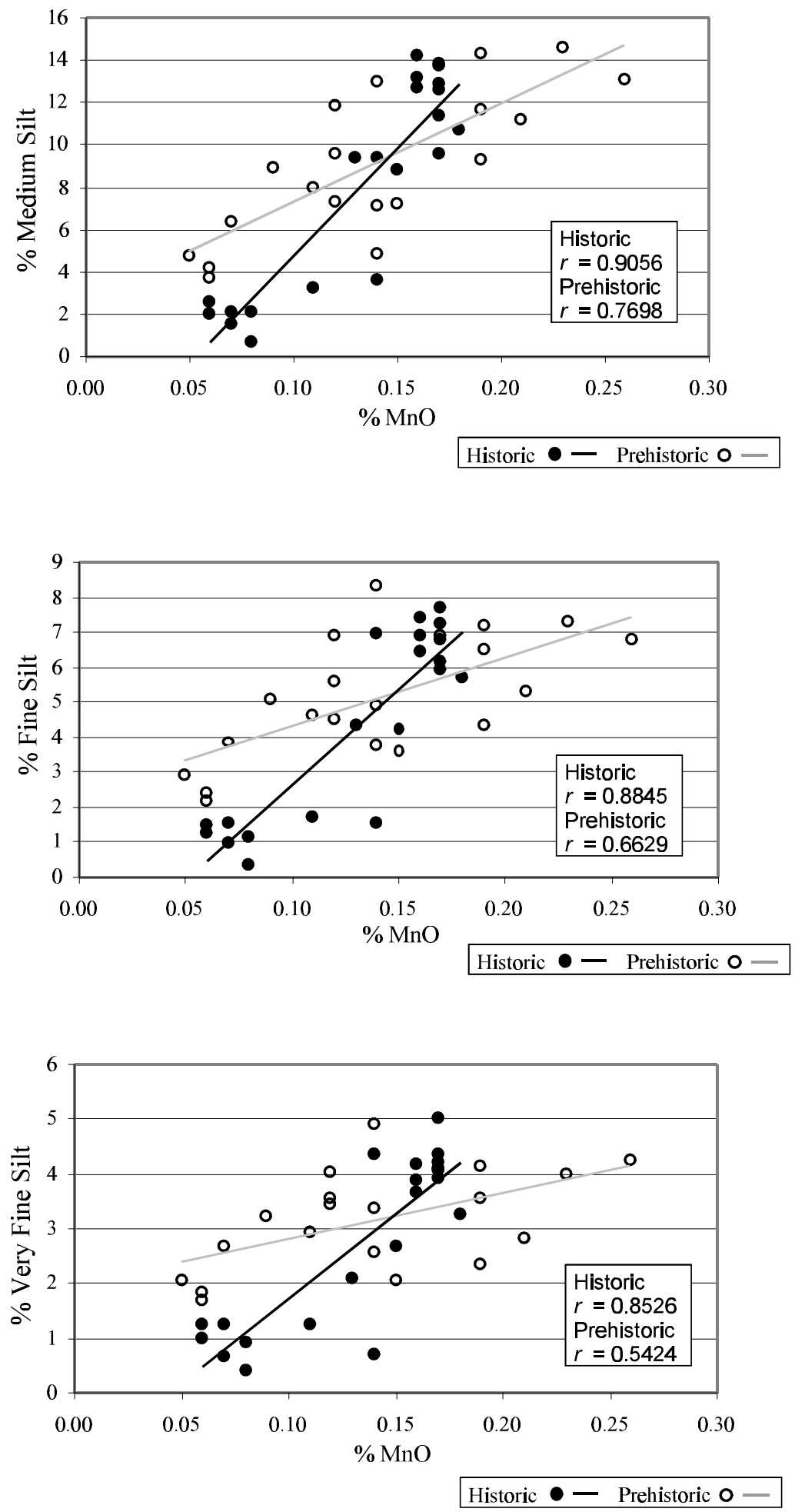


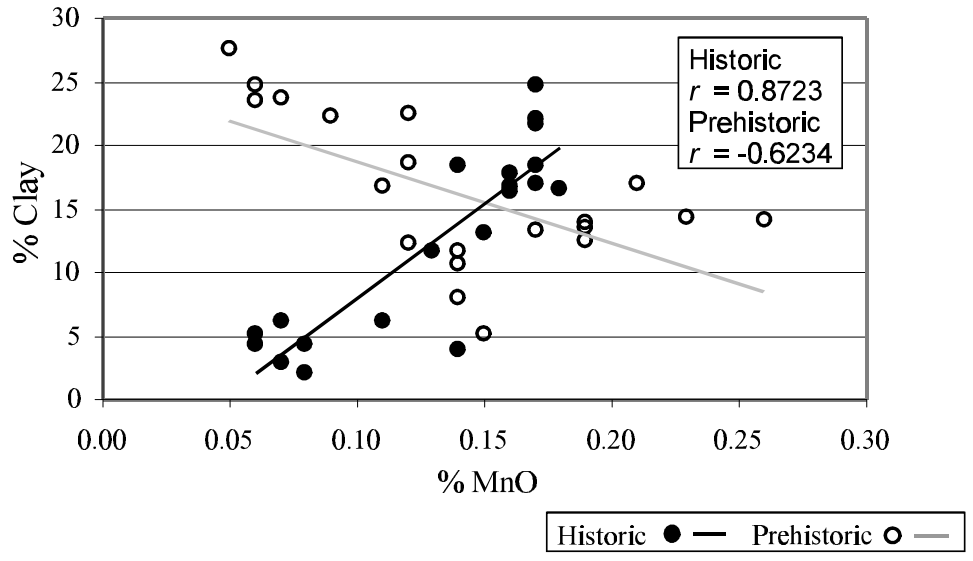




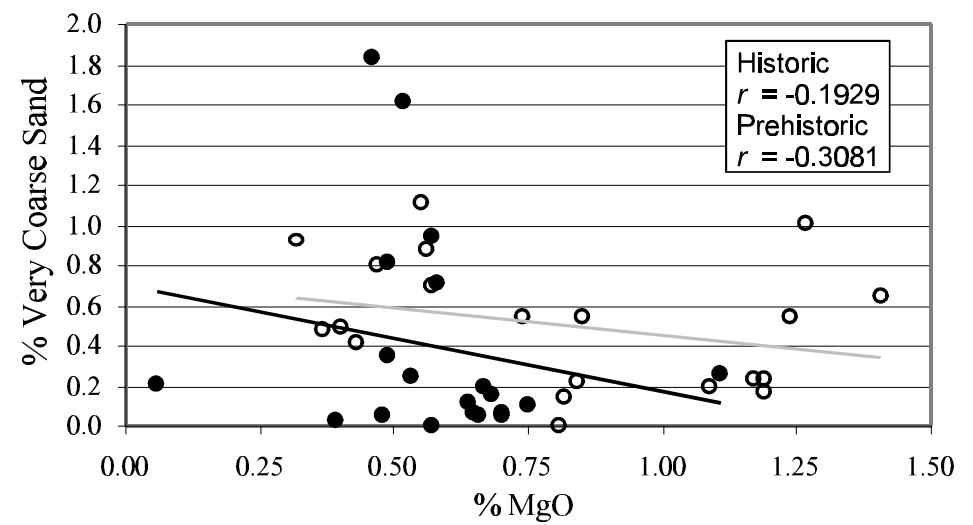

Historic $\bullet-$ Prehistoric $0-$

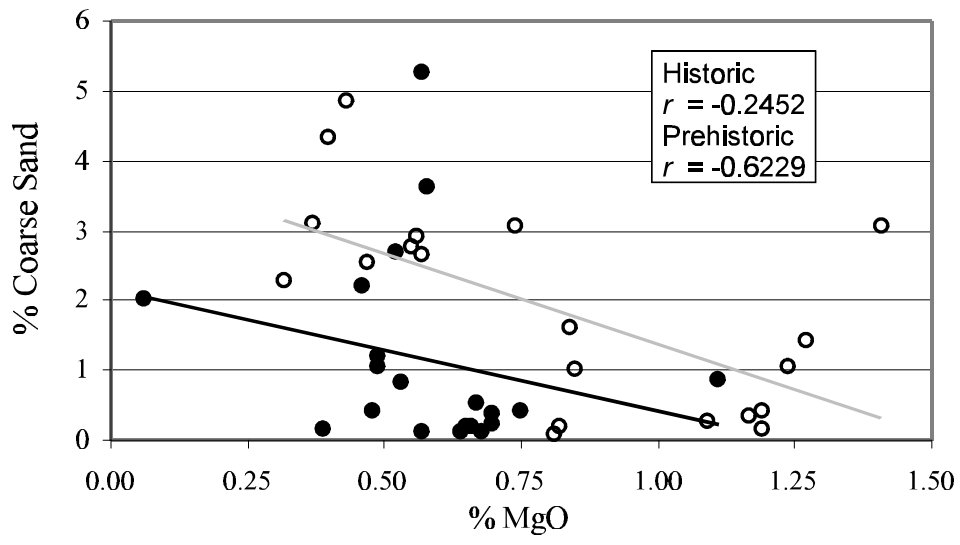

Historic $\bullet-$ Prehistoric $0-$

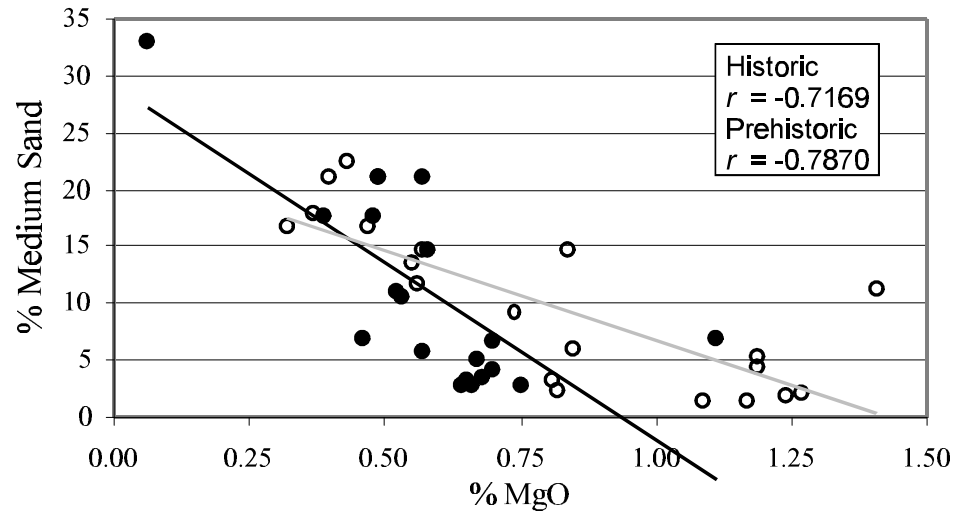

Historic $\bullet-$ Prehistoric $0-$ 


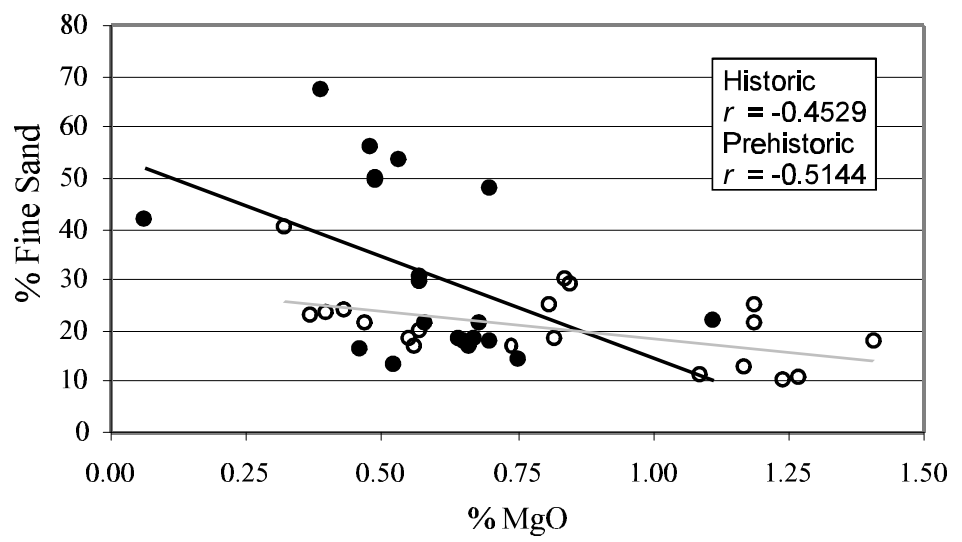

Historic $\bullet-$ Prehistoric $0-$

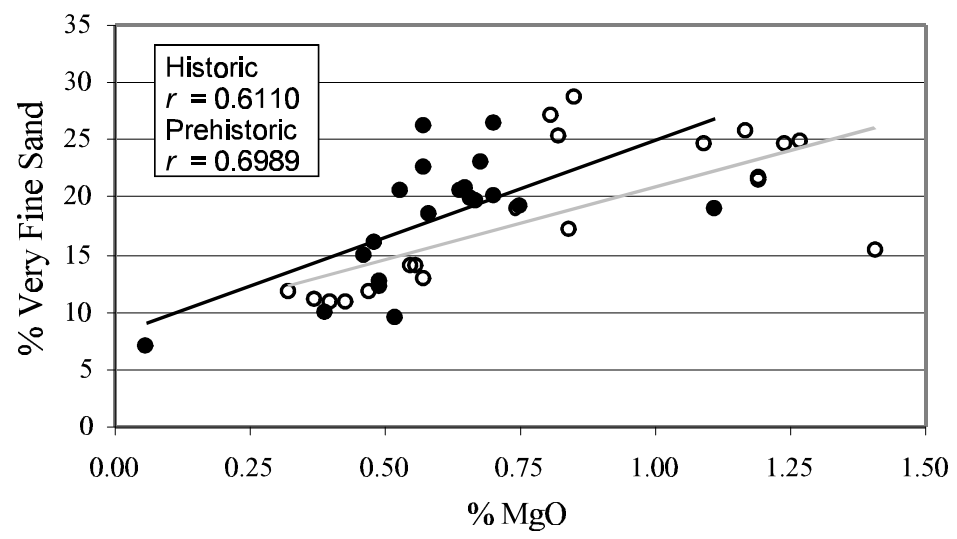

Historic $\bullet-$ Prehistoric $0-$

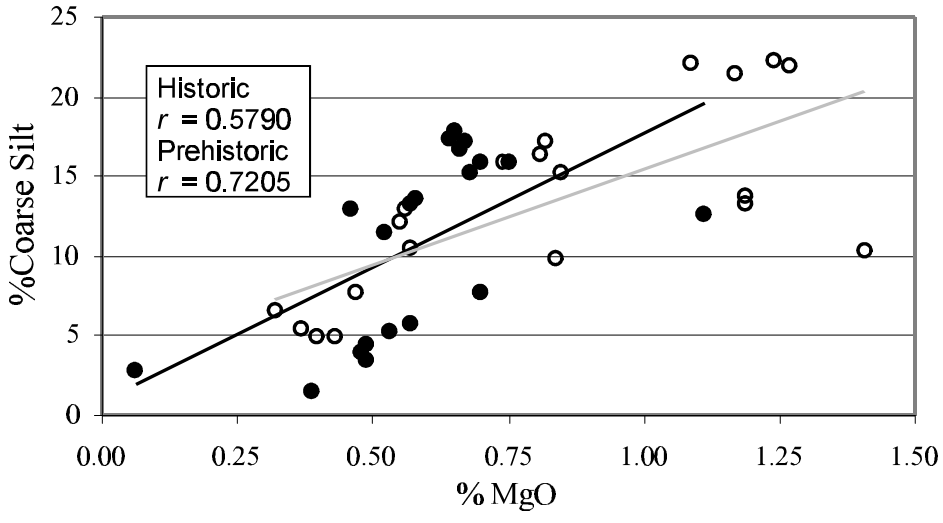

Historic $\bullet-$ Prehistoric $0-$ 


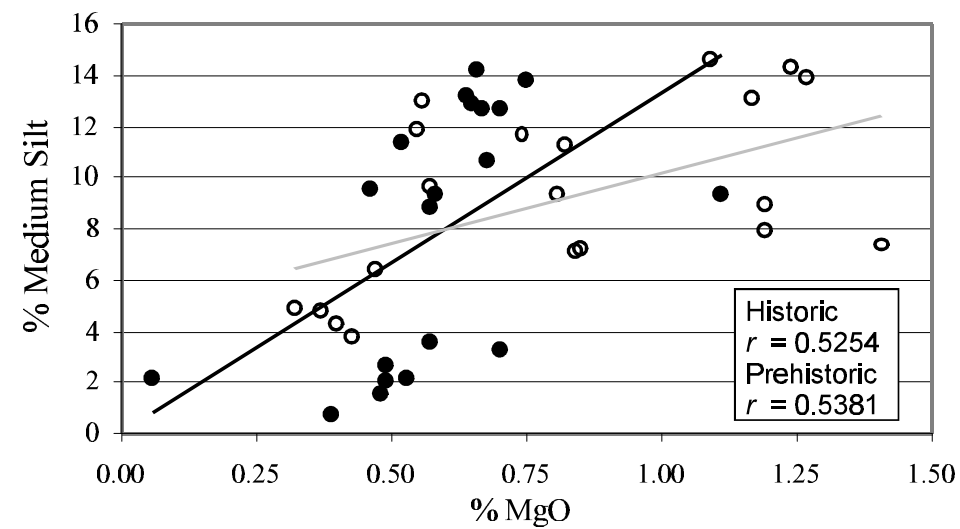

Historic $\bullet-$ Prehistoric $0-$

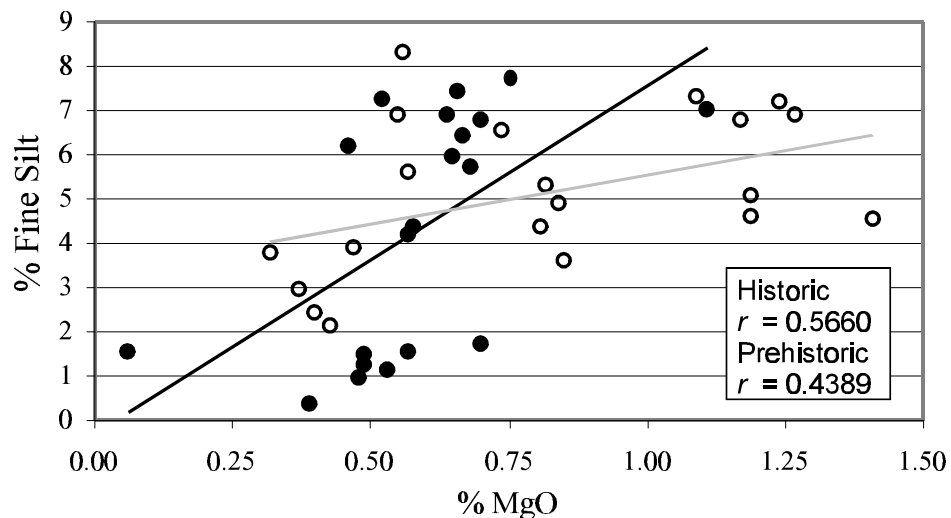

Historic $\bullet-$ Prehistoric $0-$

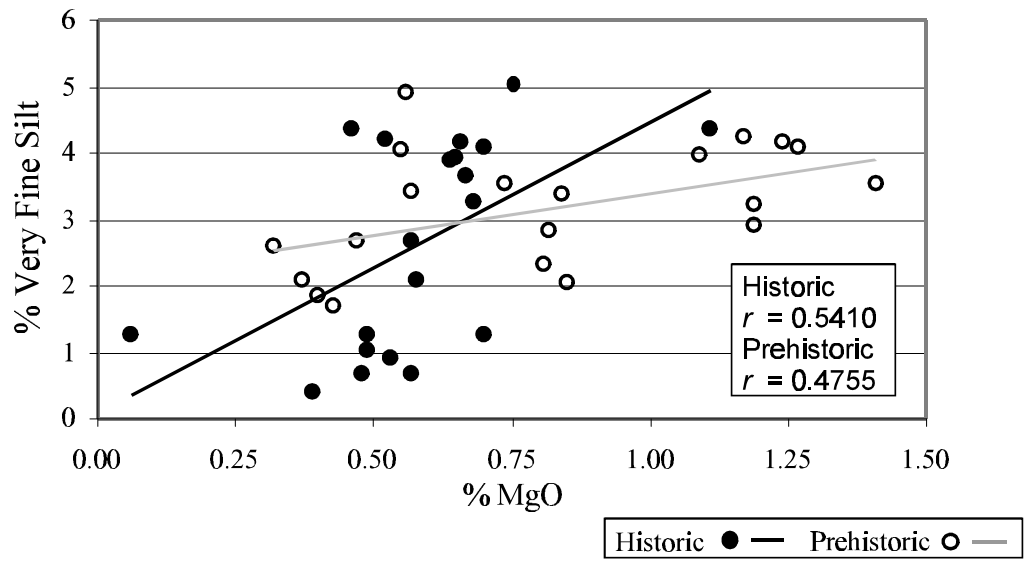




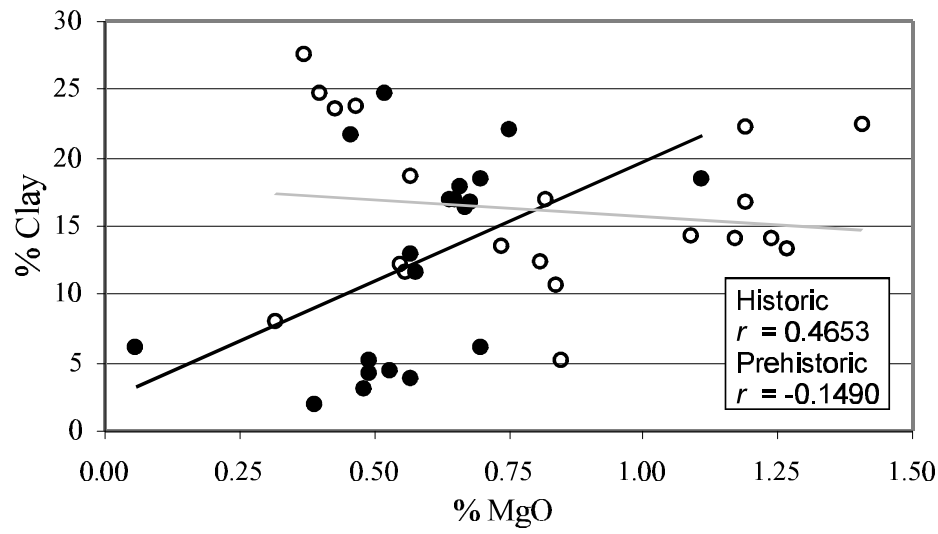

Historic $\bullet-$ Prehistoric $0-$ 


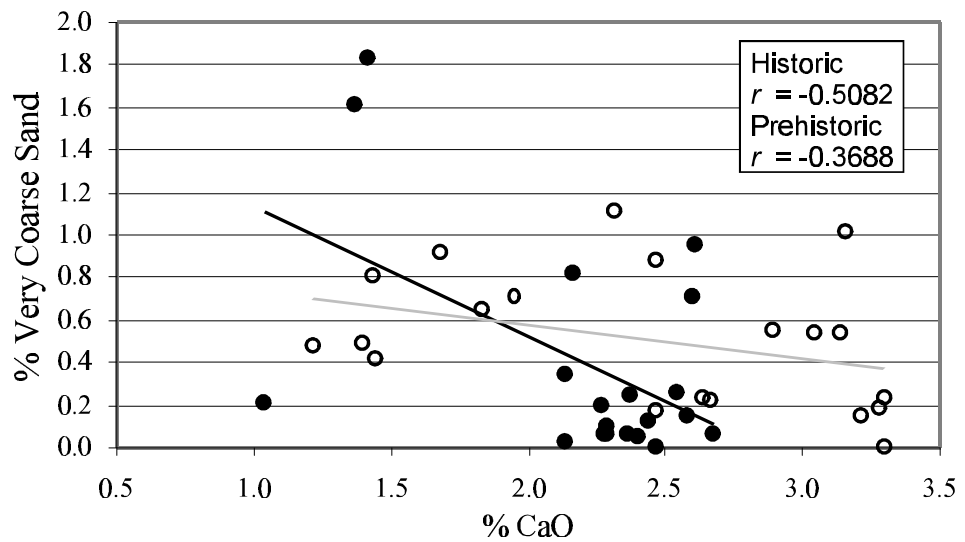

Historic $\bullet-$ Prehistoric $0-$
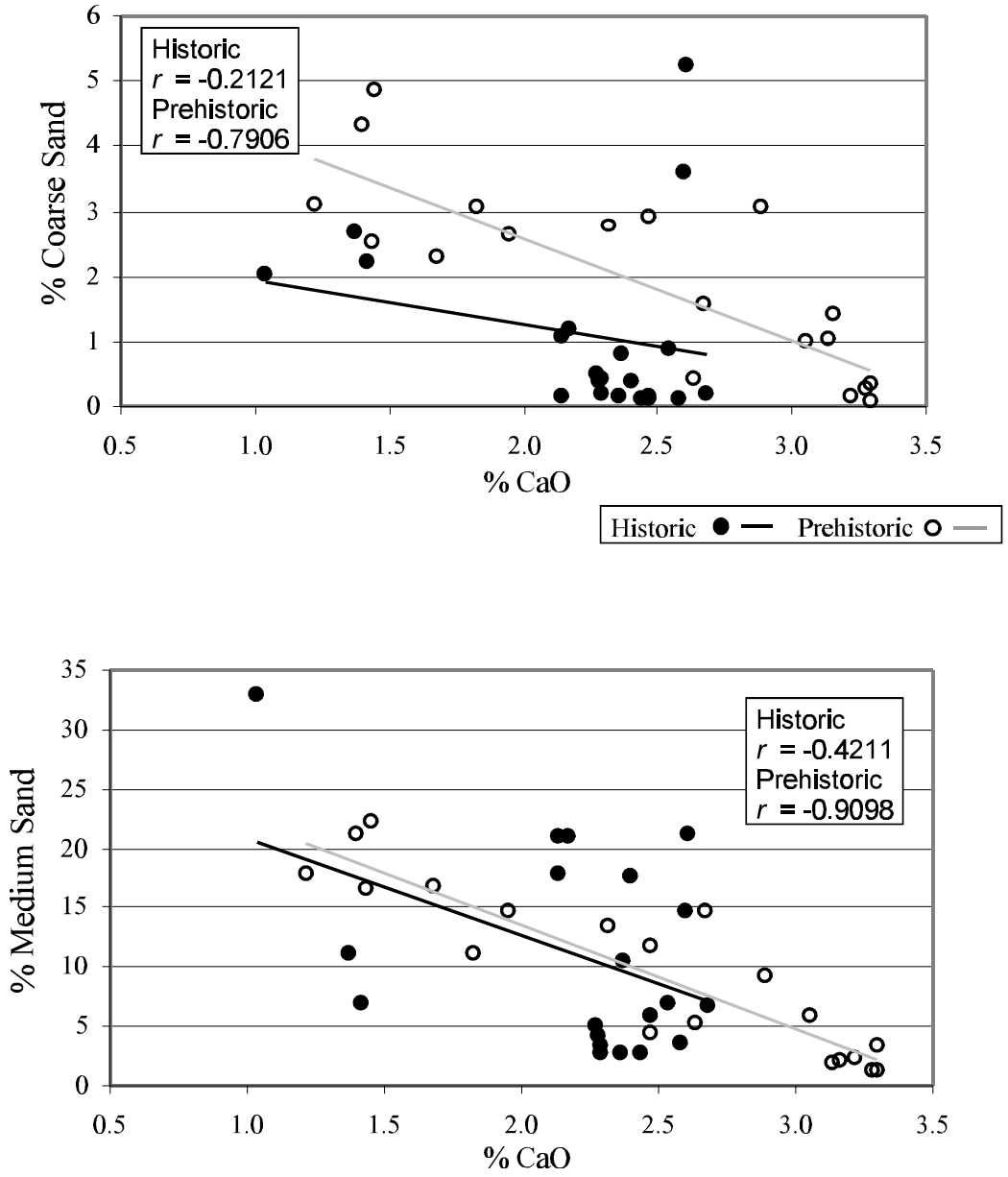

Historic $\bullet-$ Prehistoric o - 


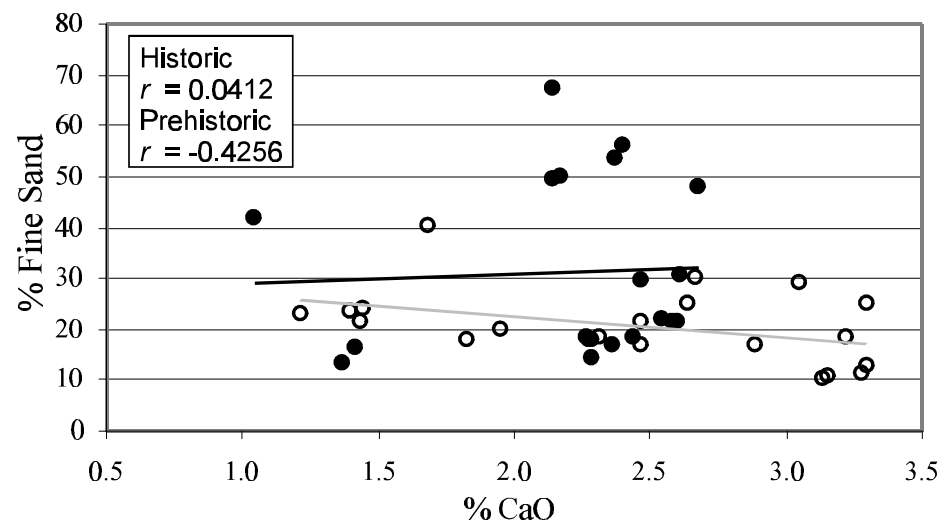

Historic $\bullet-$ Prehistoric $0-$

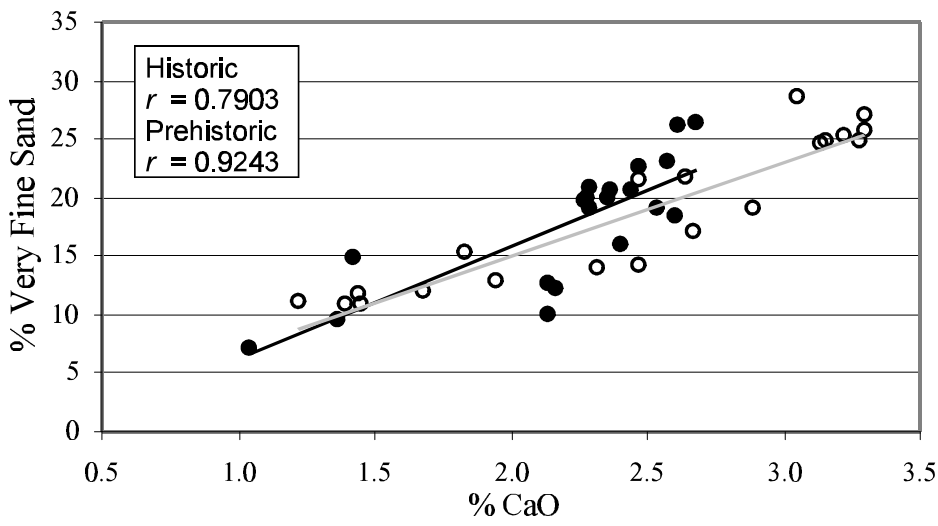

Historic $\bullet-$ Prehistoric $0-$

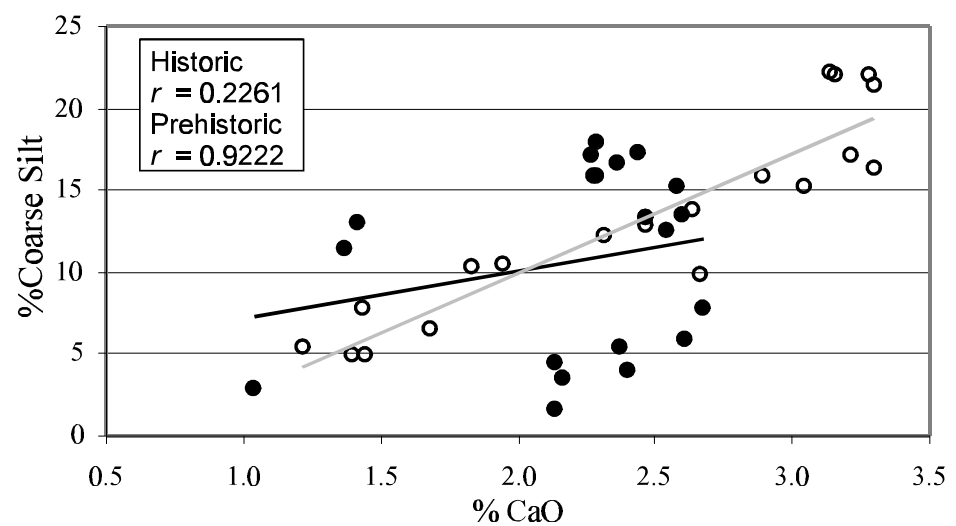

Historic $\bullet-$ Prehistoric $0-$ 

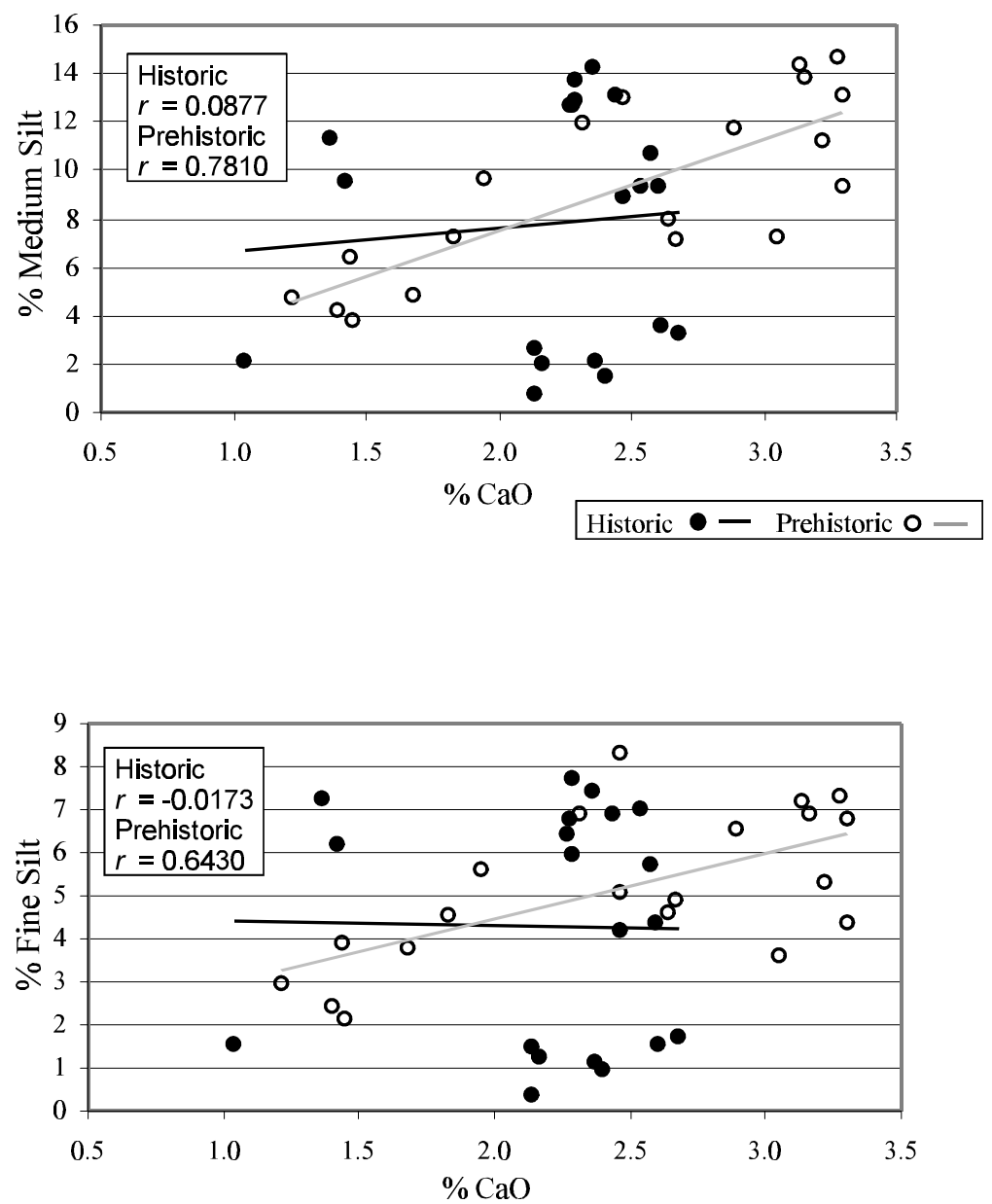

Historic $\bullet-$ Prehistoric 0

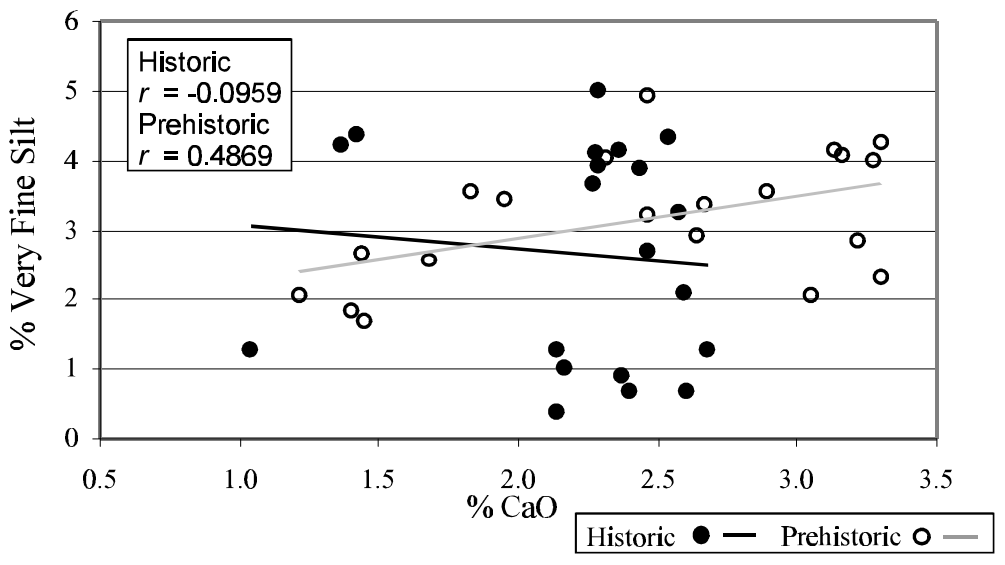




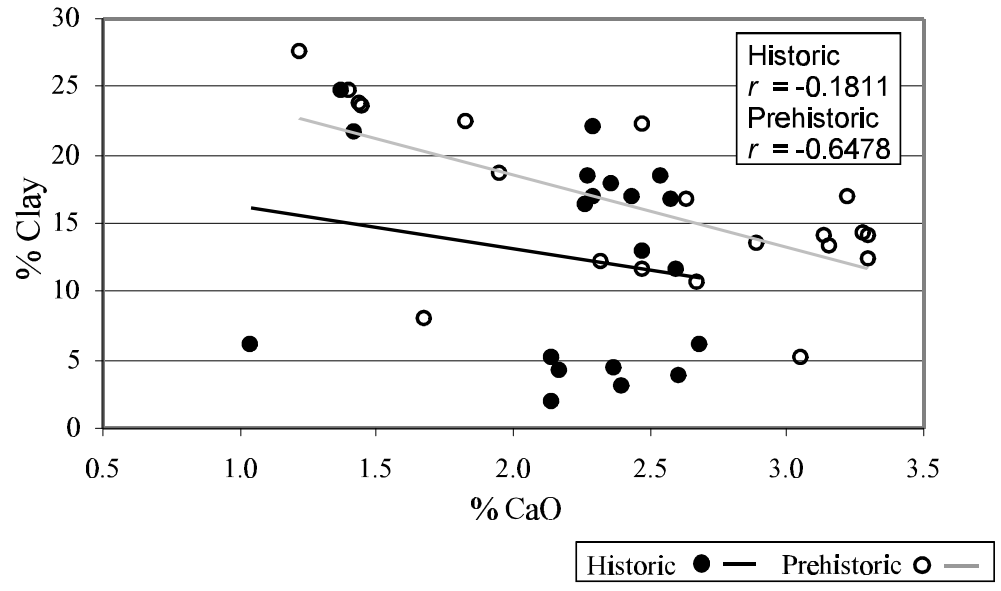




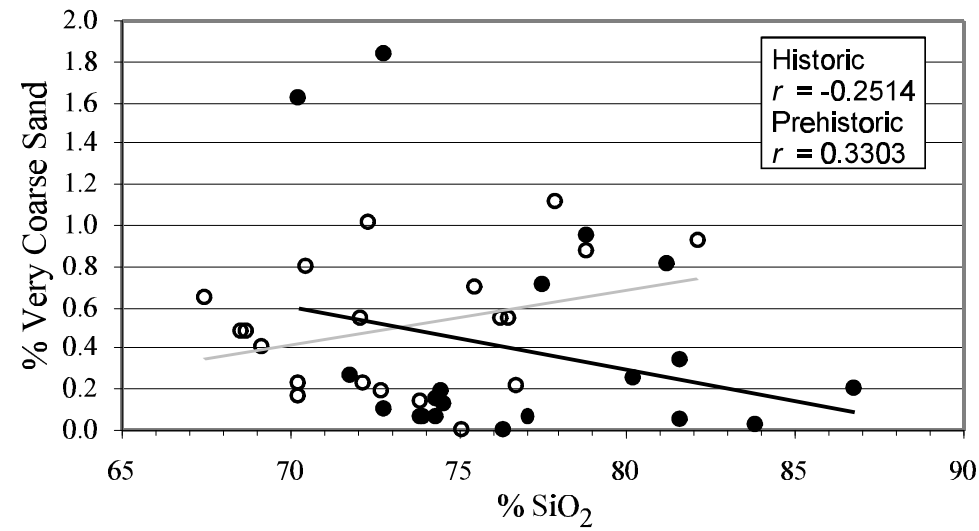

Historic $\bullet-$ Prehistoric $0-$

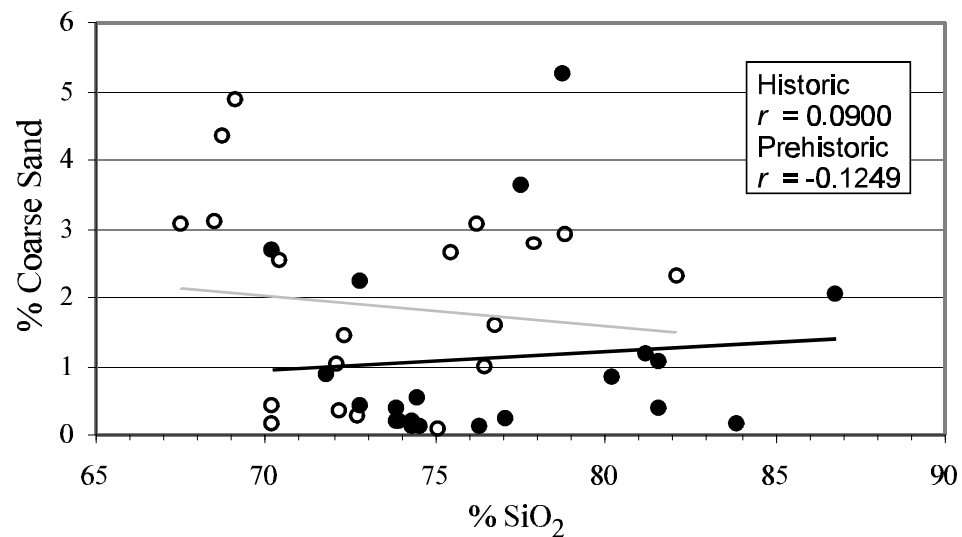

Historic $\bullet-$ Prehistoric $0-$

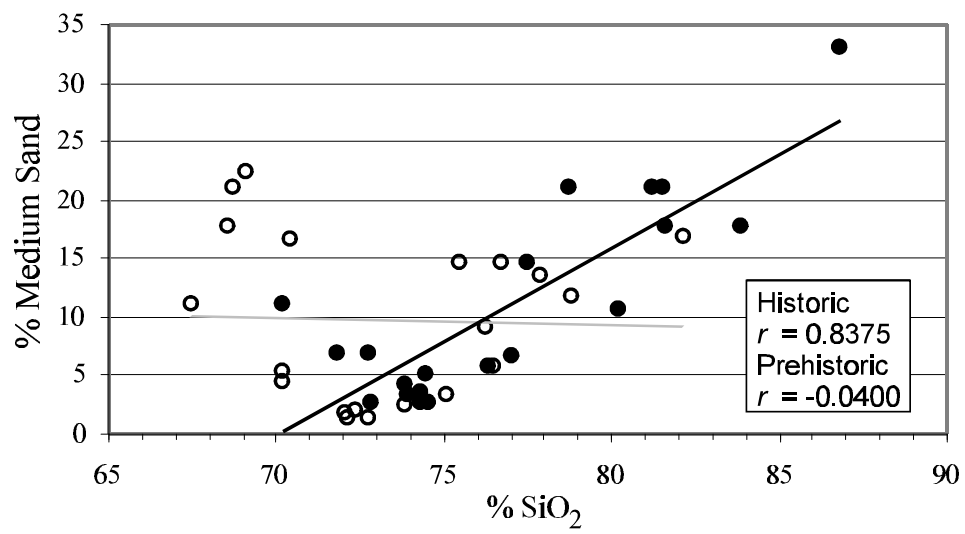

Historic $\bullet-$ Prehistoric $0-$ 

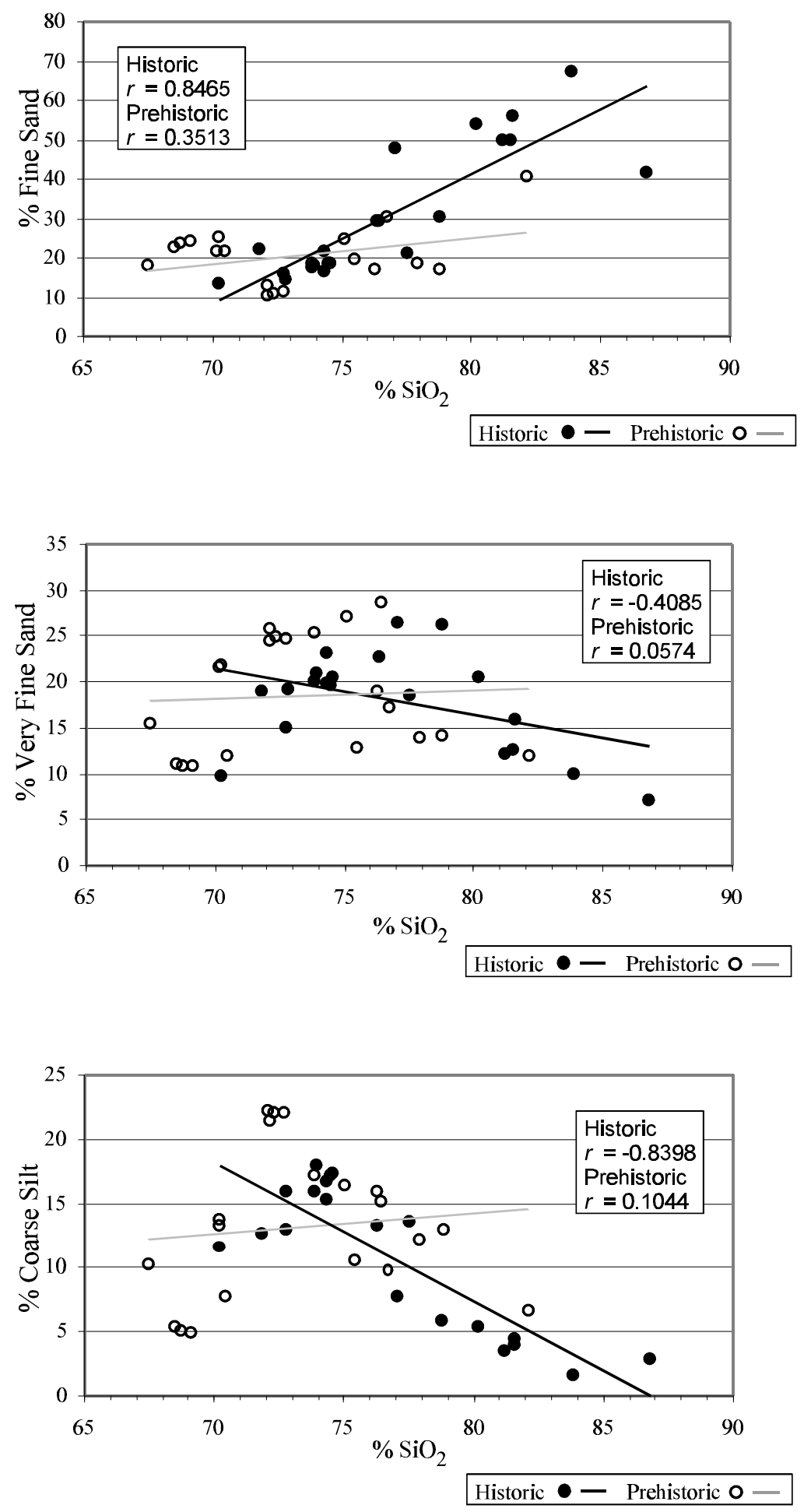

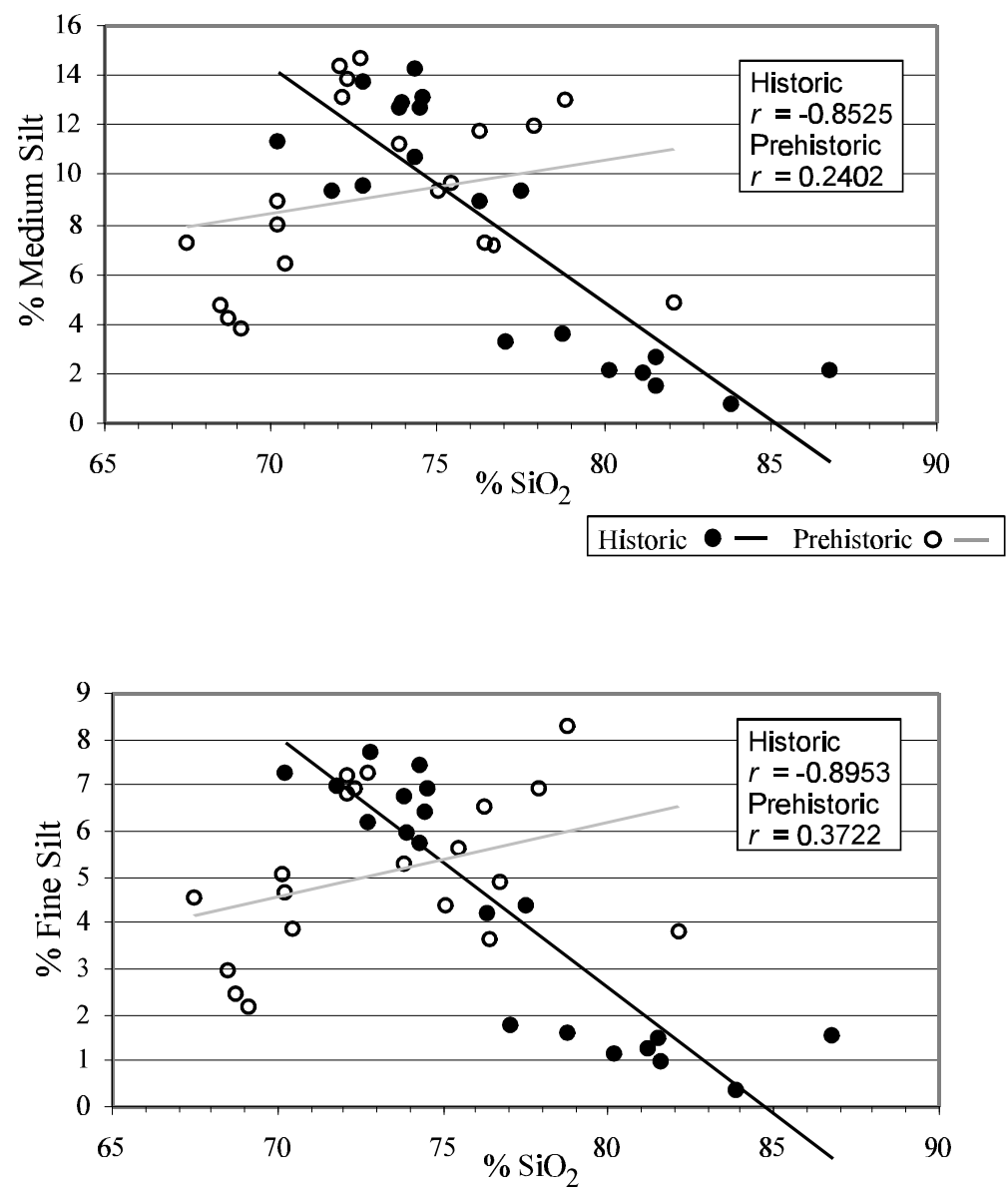

Historic $\bullet-$ Prehistoric $0-$

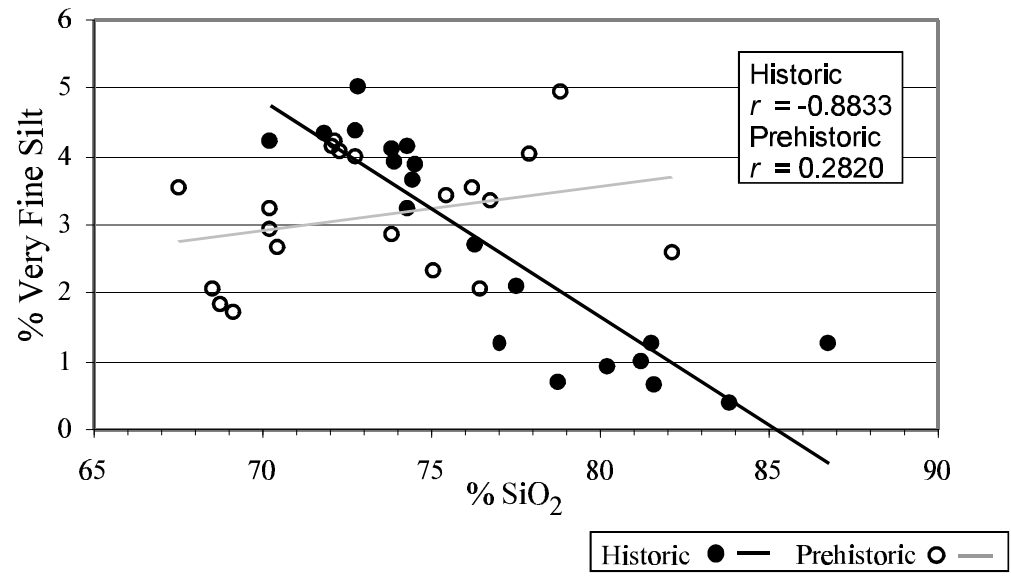




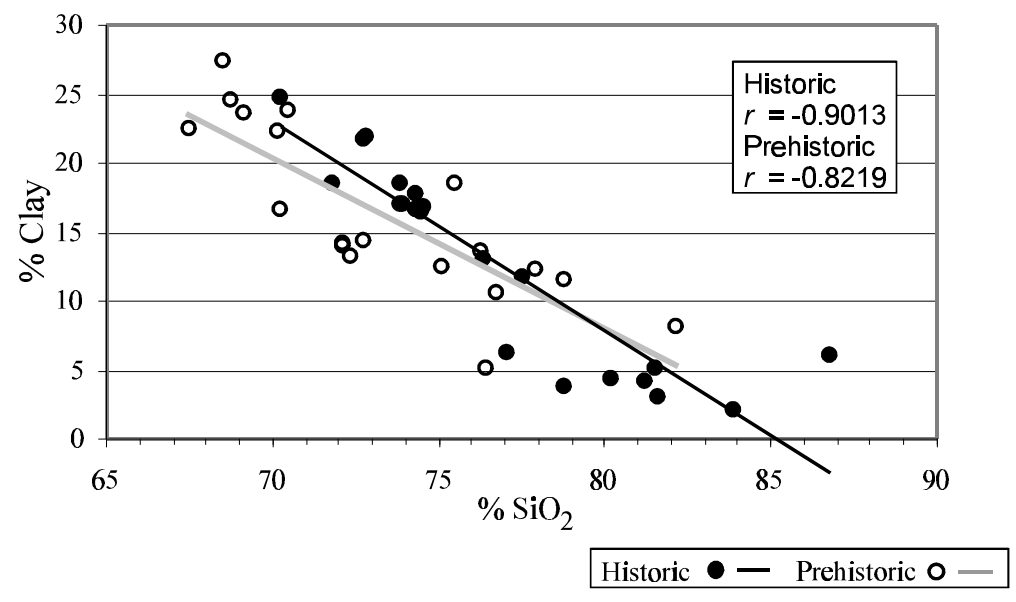




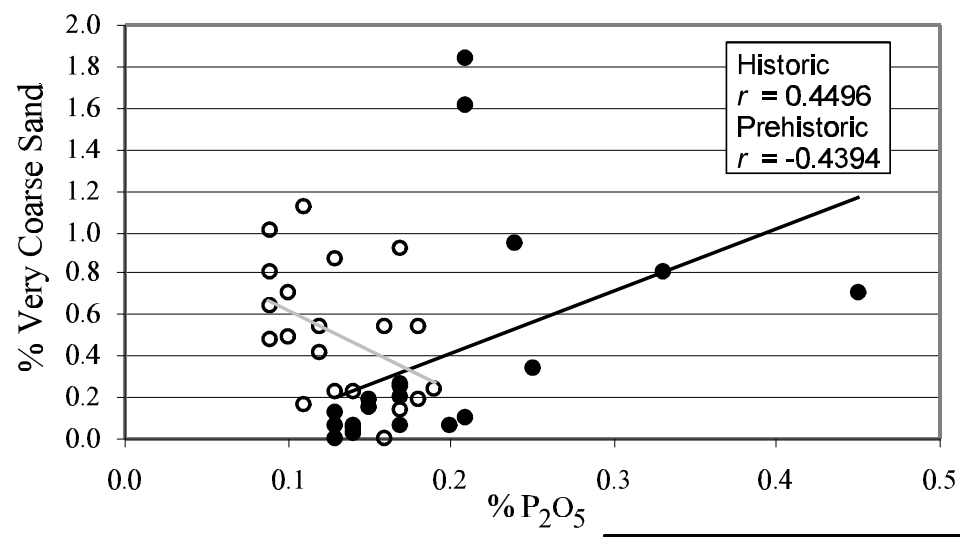

Historic $\bullet-$ Prehistoric $0-$

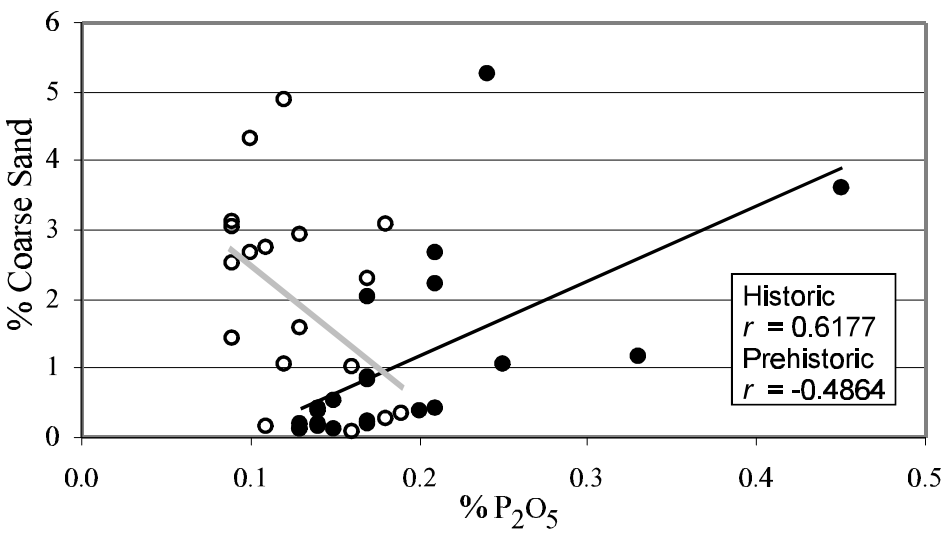

Historic $\bullet-$ Prehistoric $0-$

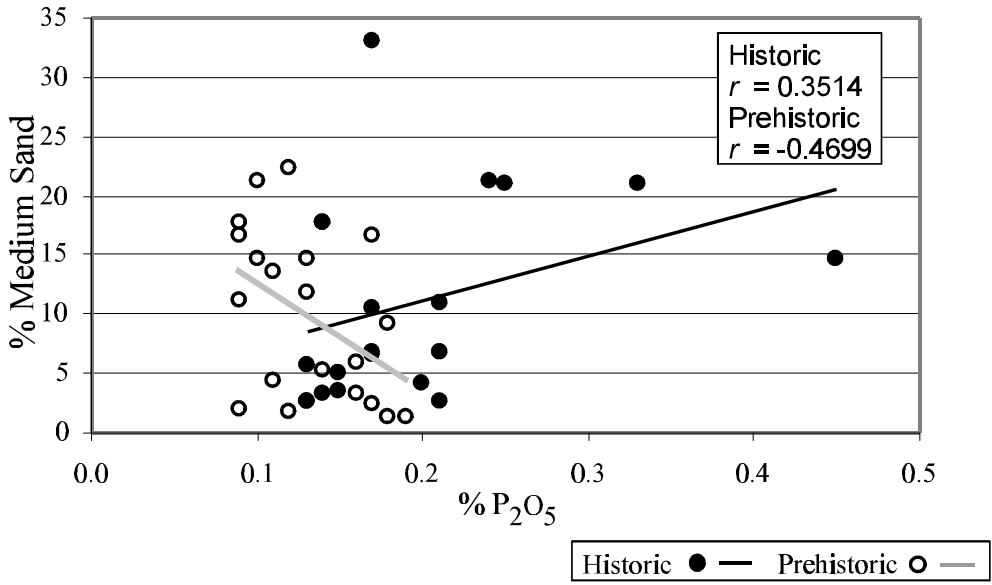




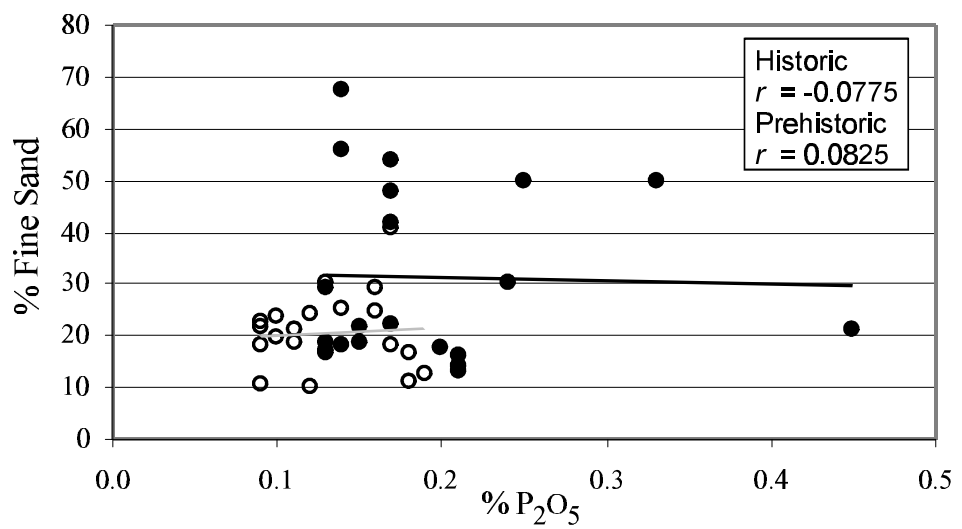

Historic $\bullet-$ Prehistoric $0-$

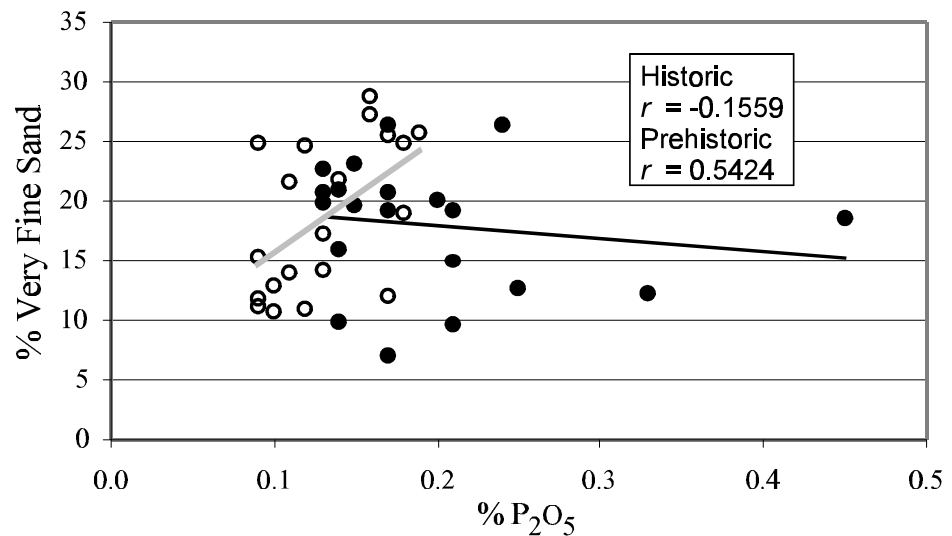

Historic $\bullet-$ Prehistoric $0-$

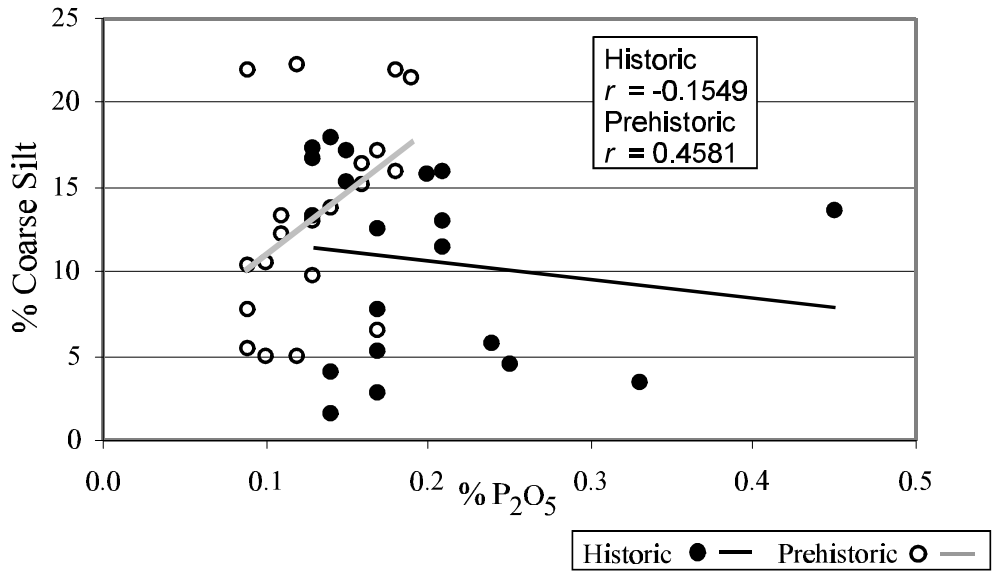



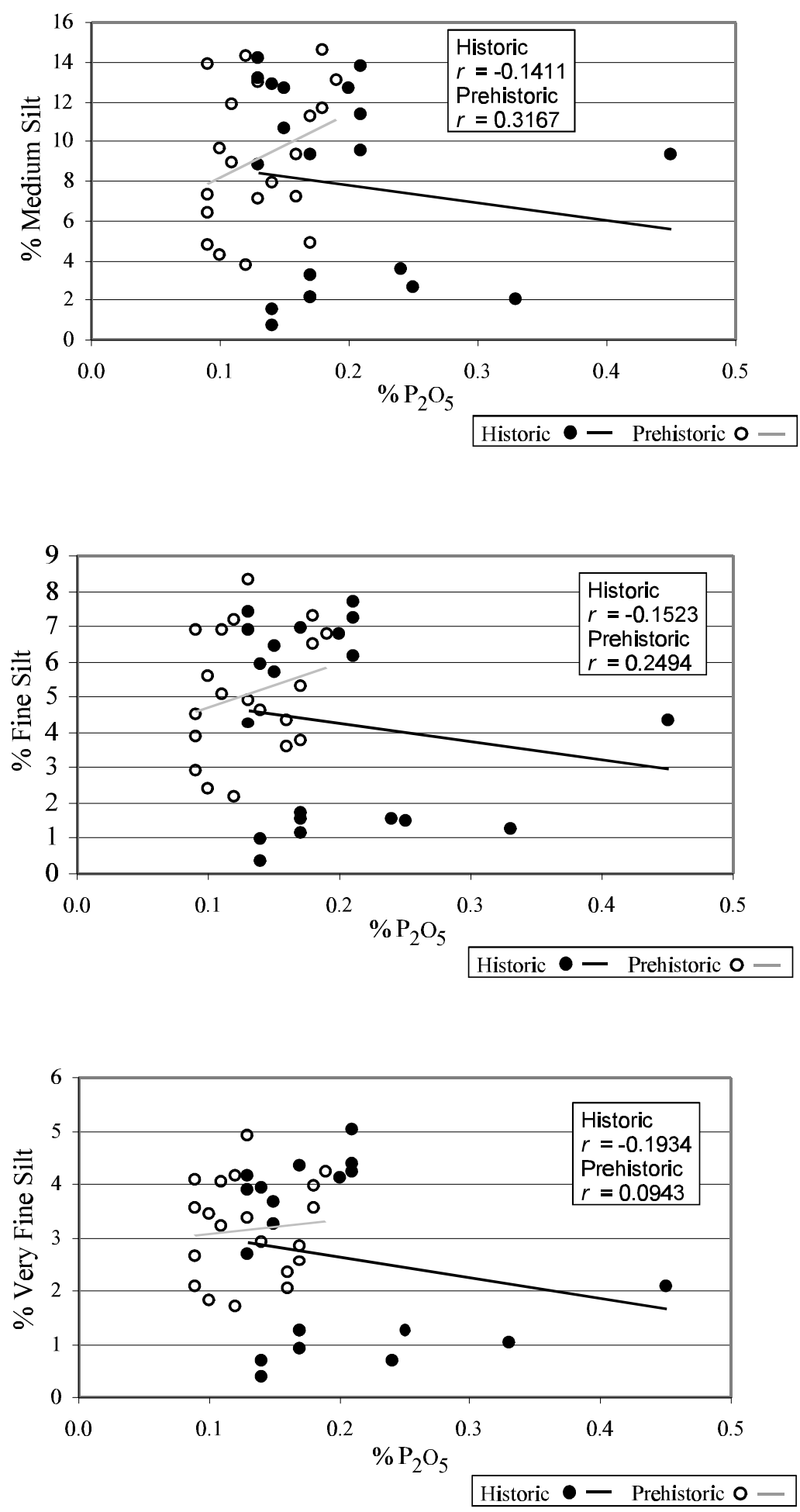


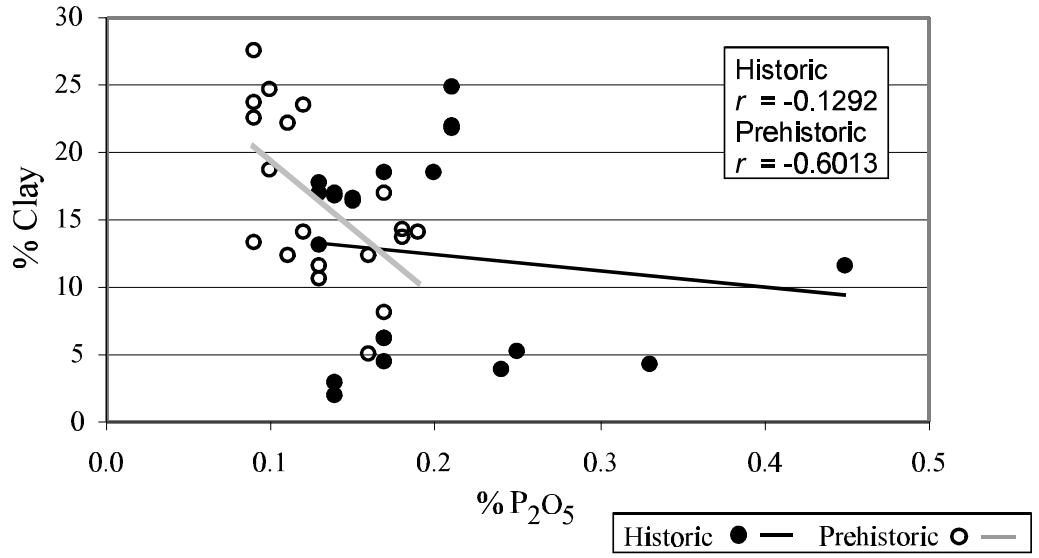




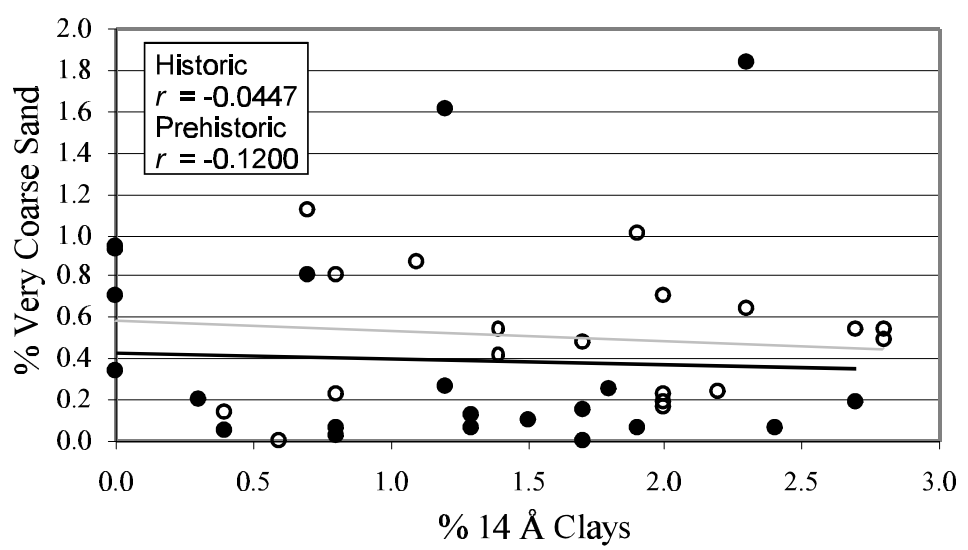

Historic $\bullet-$ Prehistoric $0-$

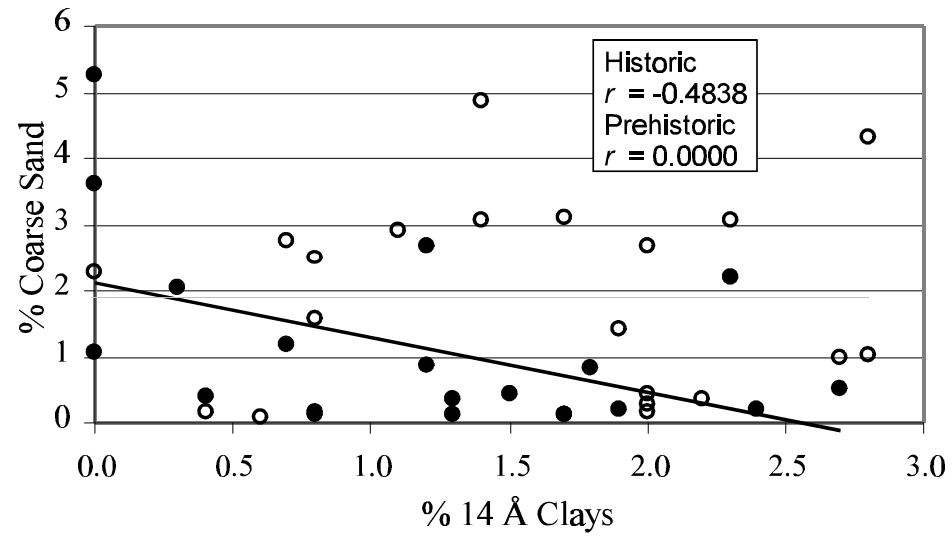

Historic $\bullet-$ Prehistoric $0-$

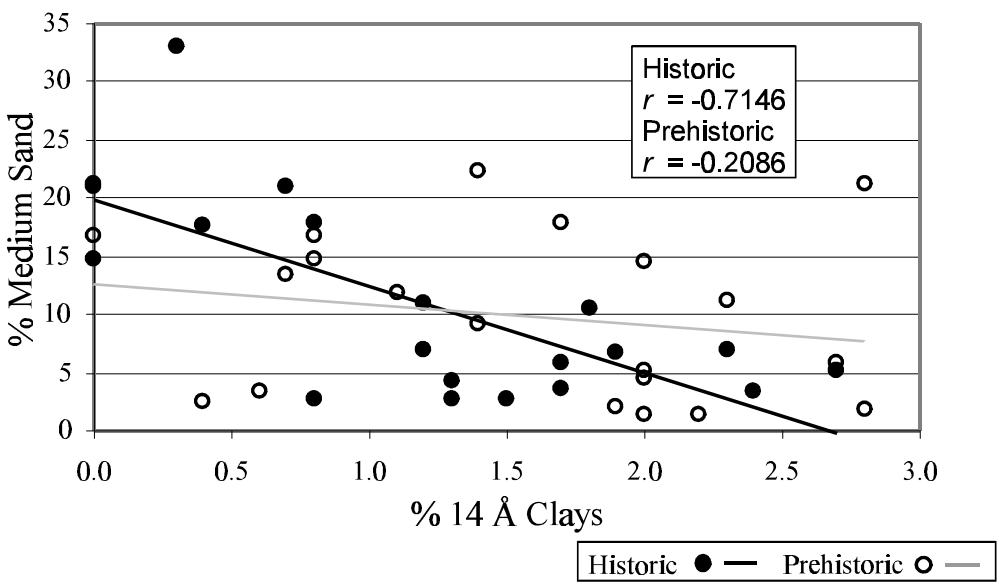




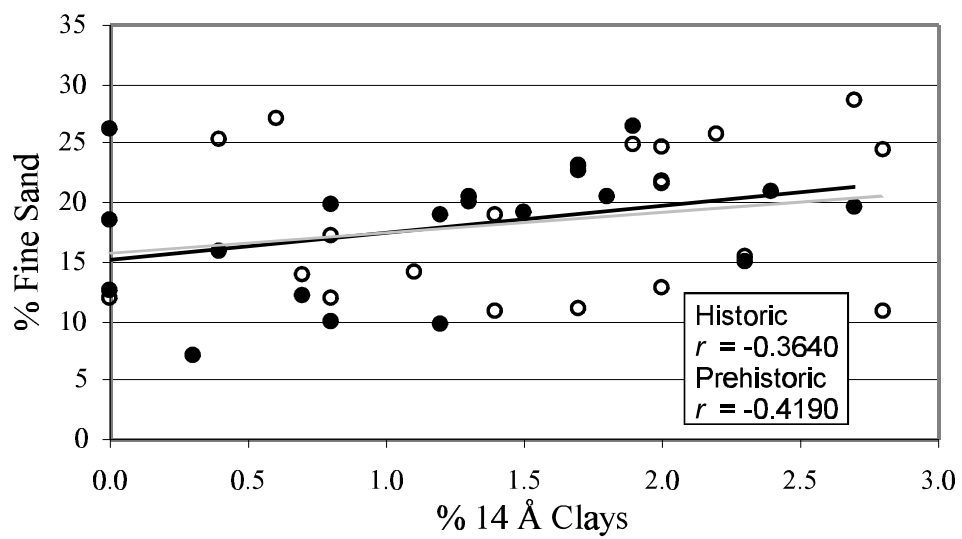

Historic $\bullet-$ Prehistoric $0-$

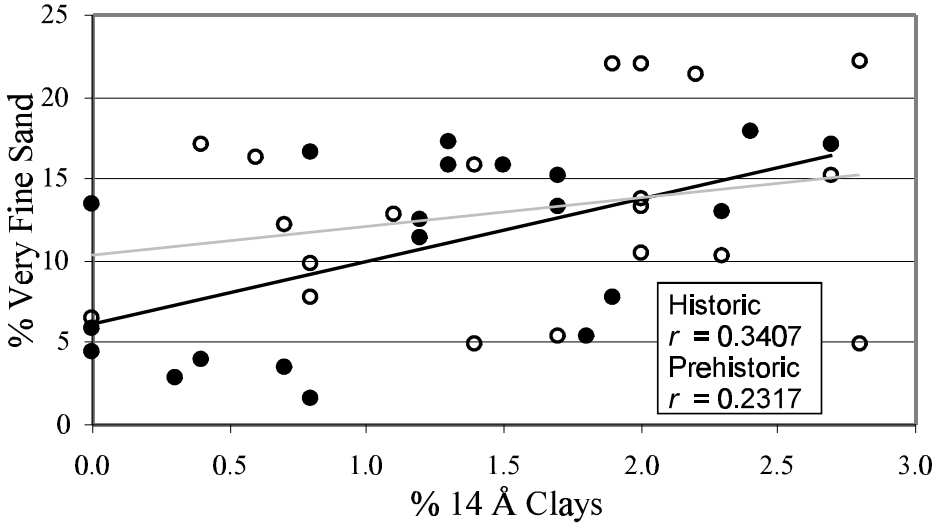

Historic $\bullet-$ Prehistoric $0-$

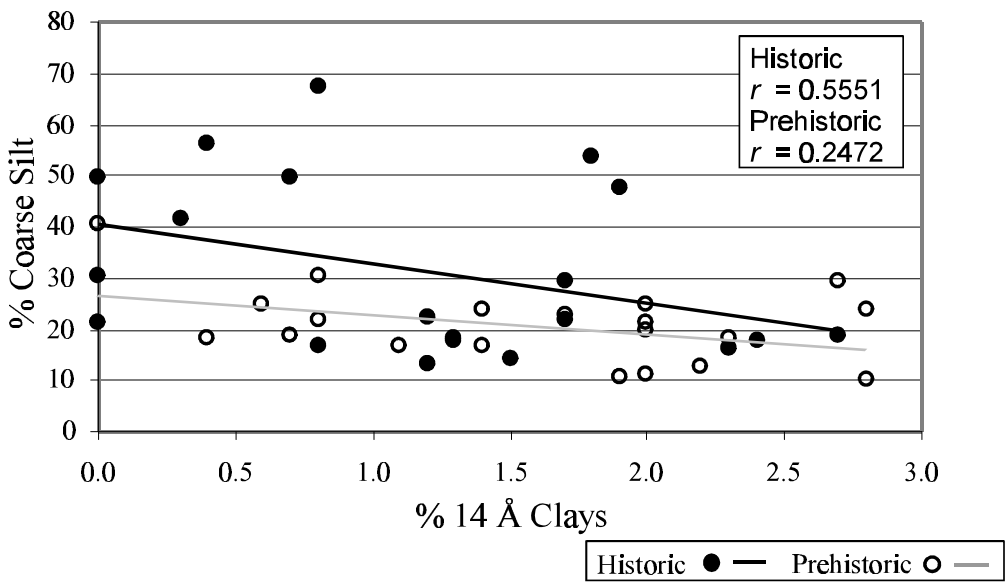




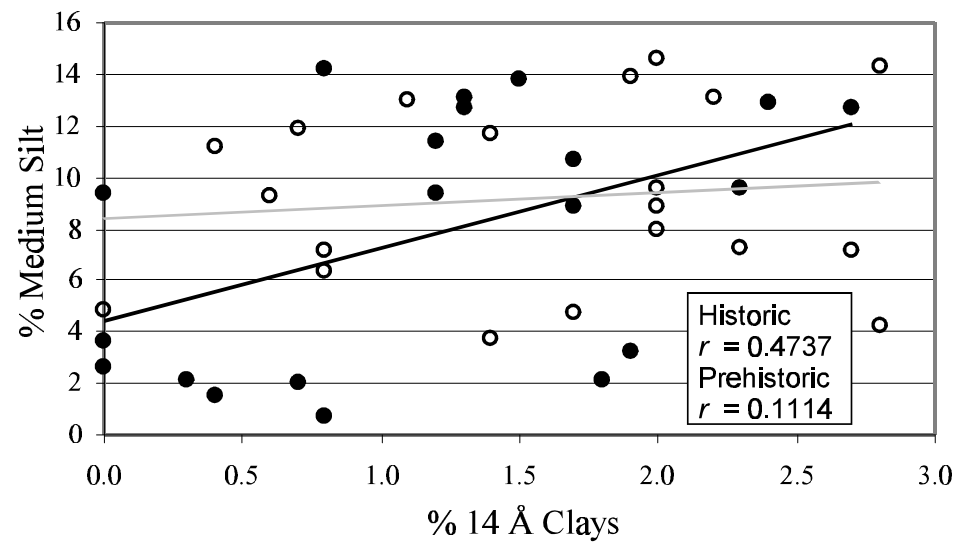

Historic $\bullet-$ Prehistoric $0-$

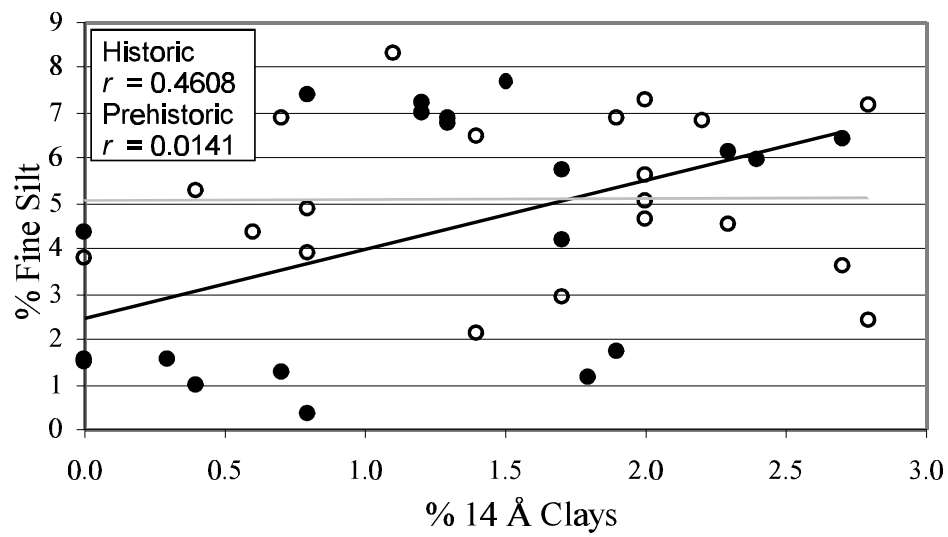

Historic $\bullet-$ Prehistoric $0-$

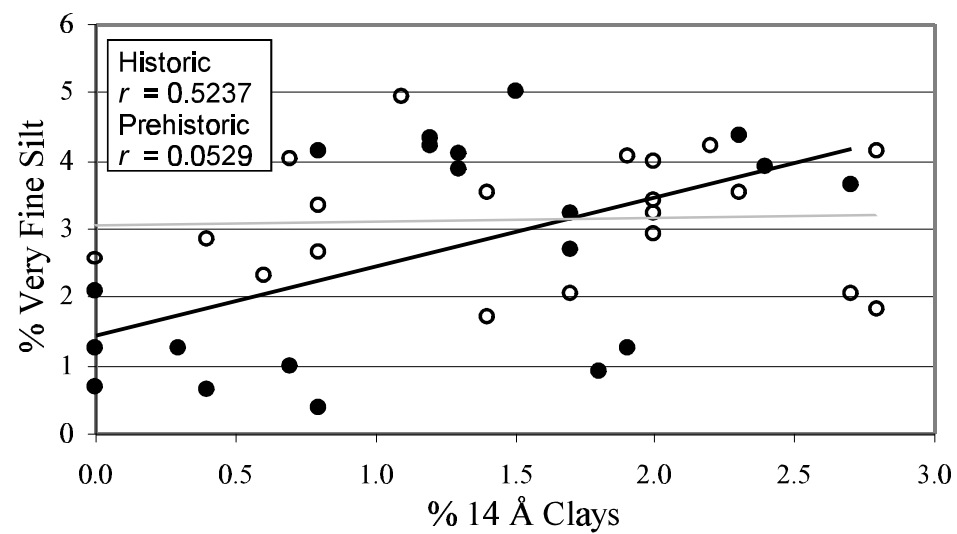

Historic $\bullet-$ Prehistoric $0-$ 


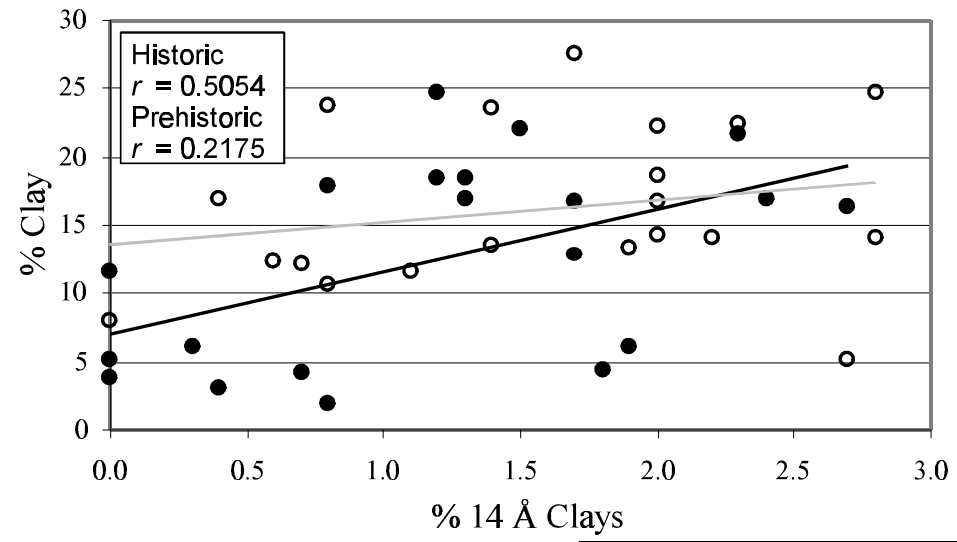

Historic $\bullet-$ Prehistoric $0-$ 


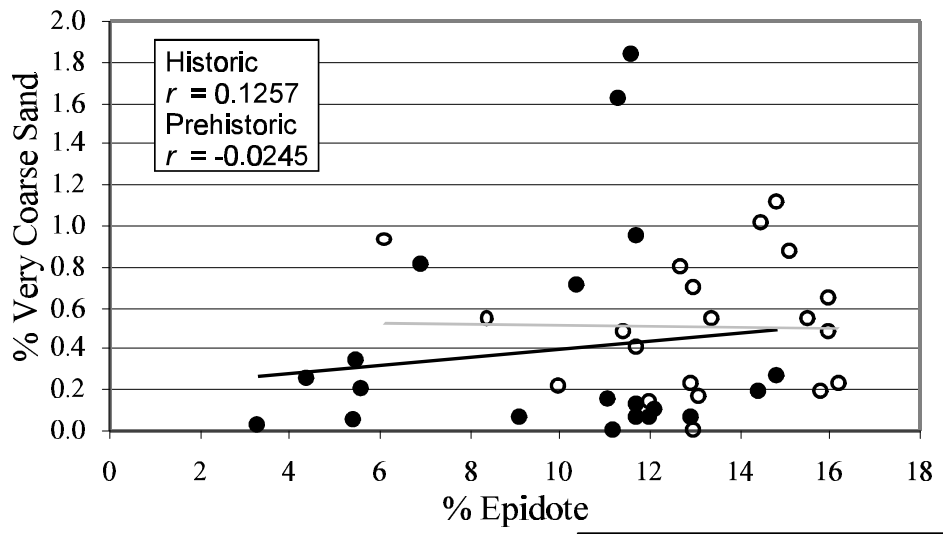

Historic $\bullet-$ Prehistoric $0-$
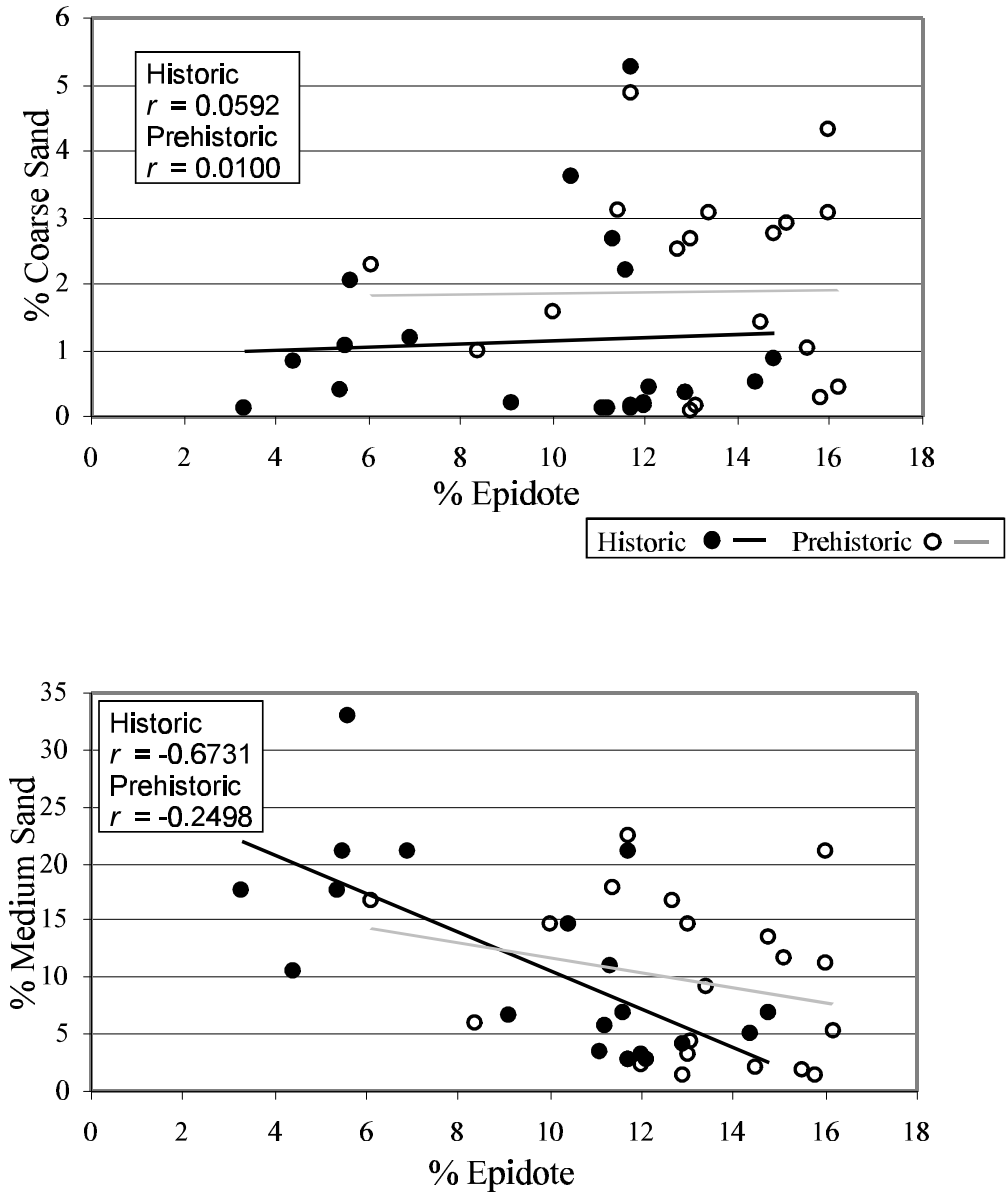

Historic $\bullet-$ Prehistoric $0-$ 


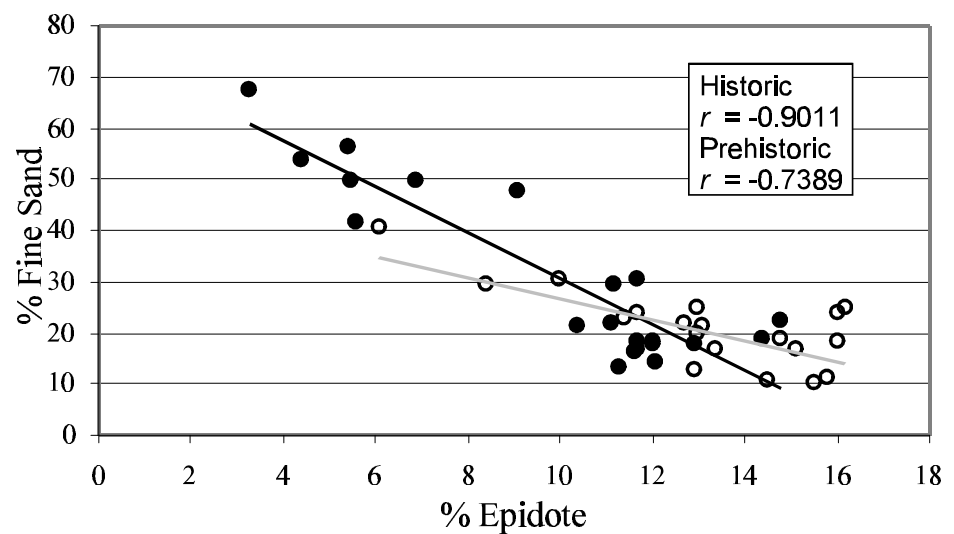

Historic $\bullet-$ Prehistoric $0-$

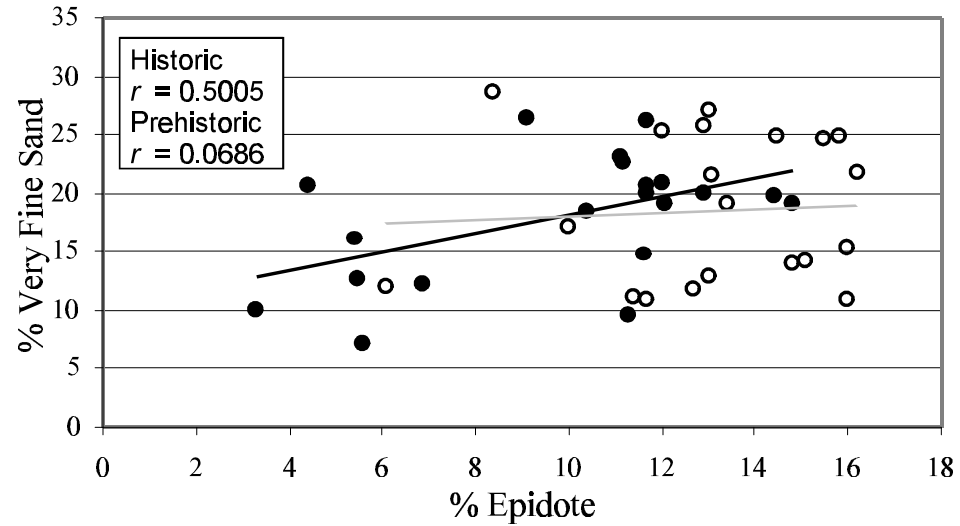

Historic $\bullet-$ Prehistoric $0-$

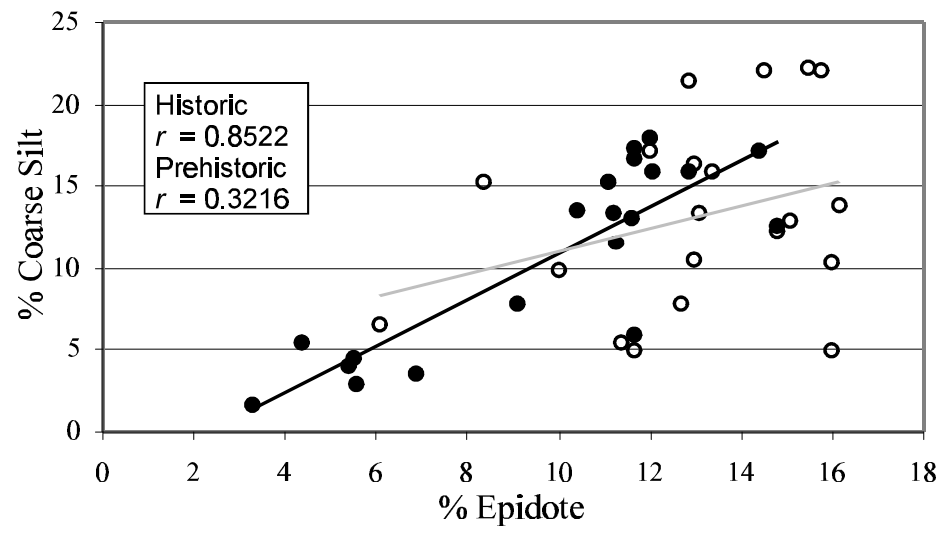

Historic $\bullet-$ Prehistoric $0-$ 


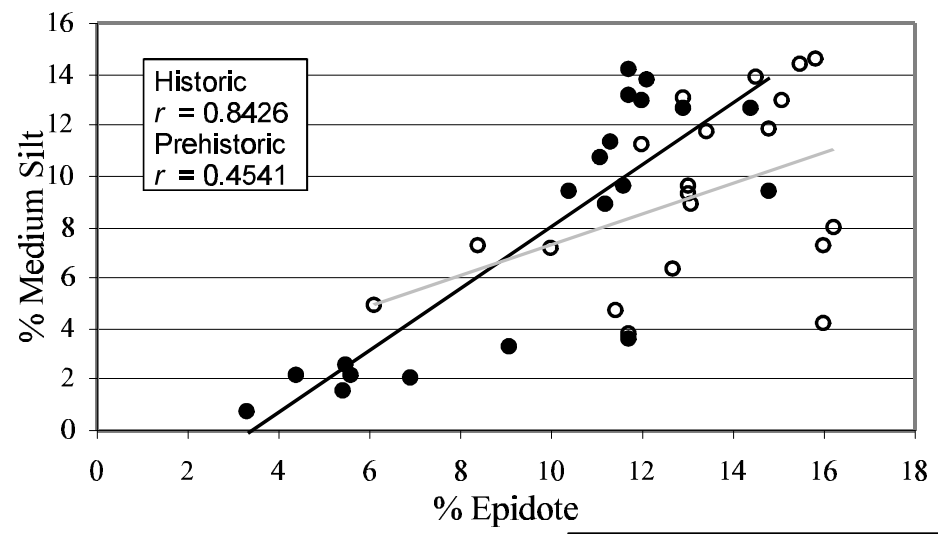

Historic $\bullet-$ Prehistoric $0-$

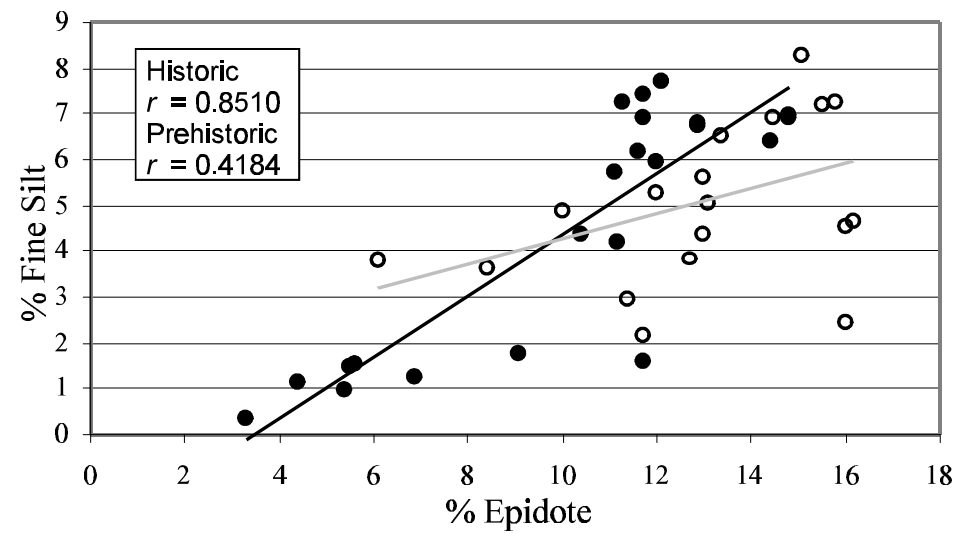

Historic $\bullet-$ Prehistoric $0-$

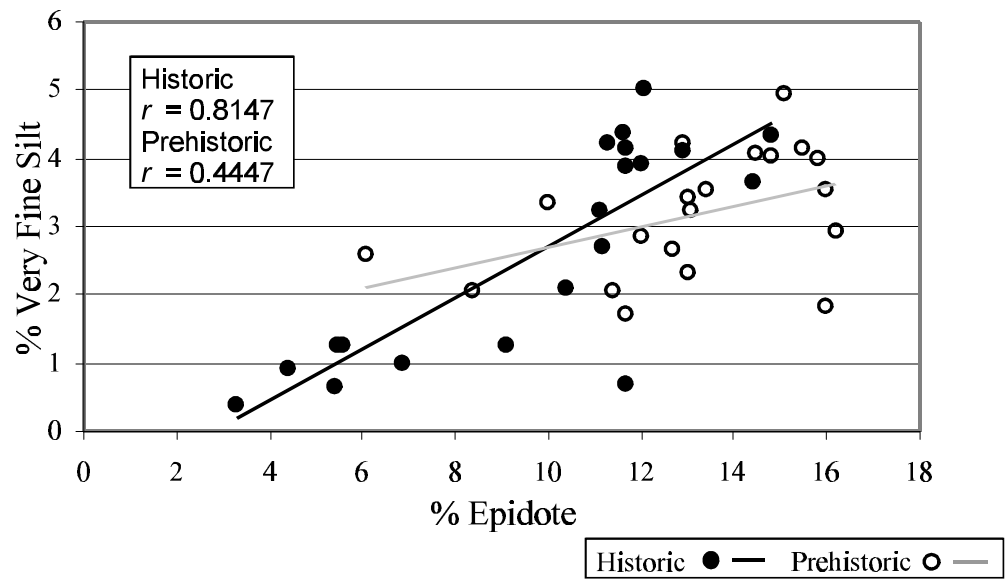




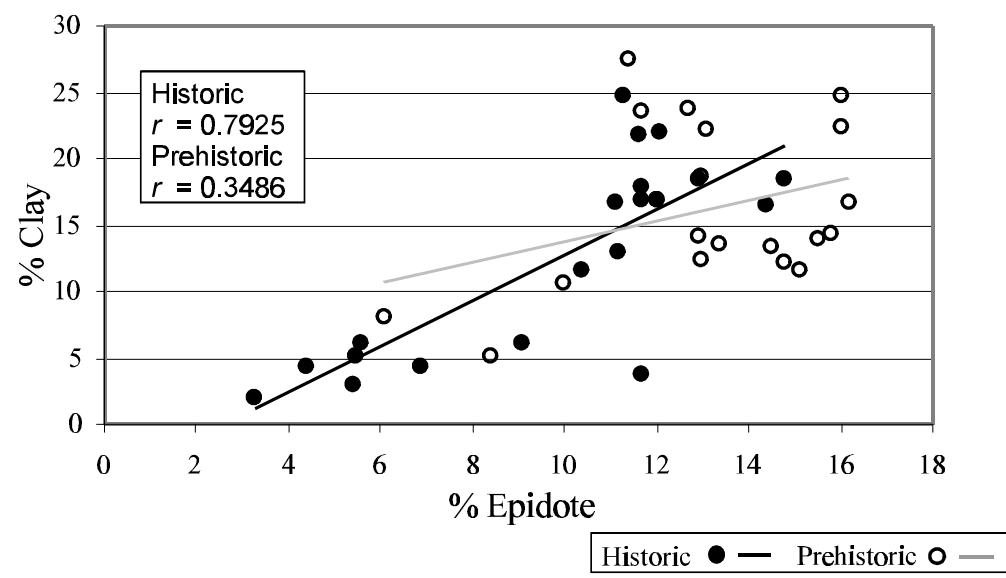




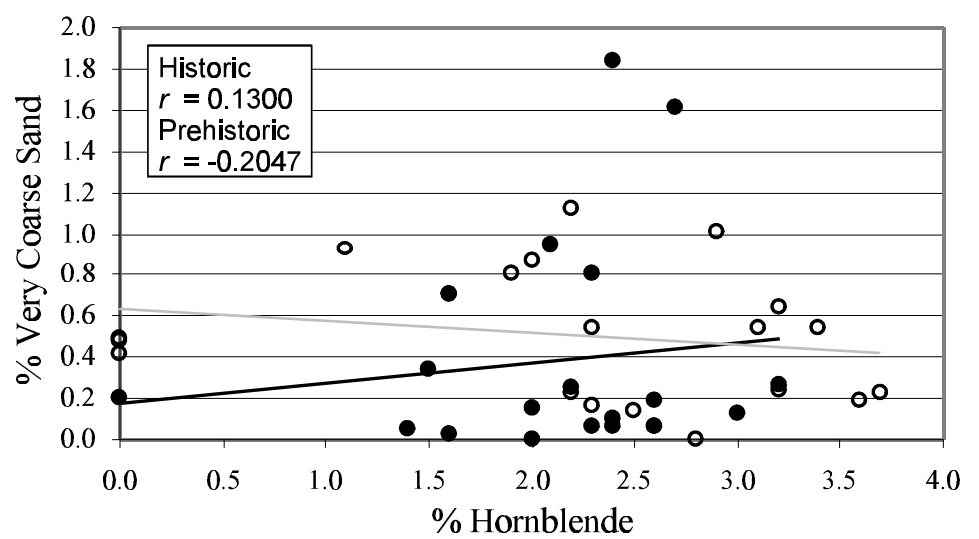

Historic $\bullet-$ Prehistoric $0-$

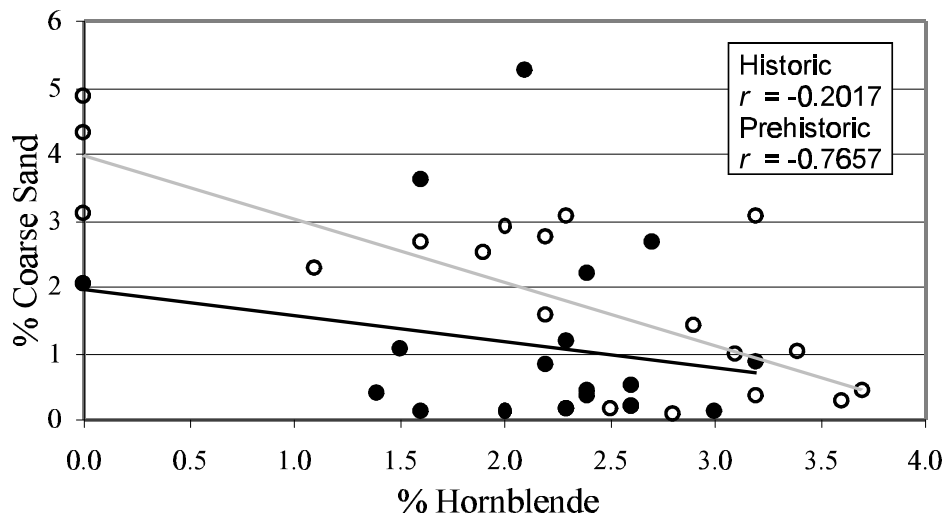

Historic $\bullet-$ Prehistoric $0-$

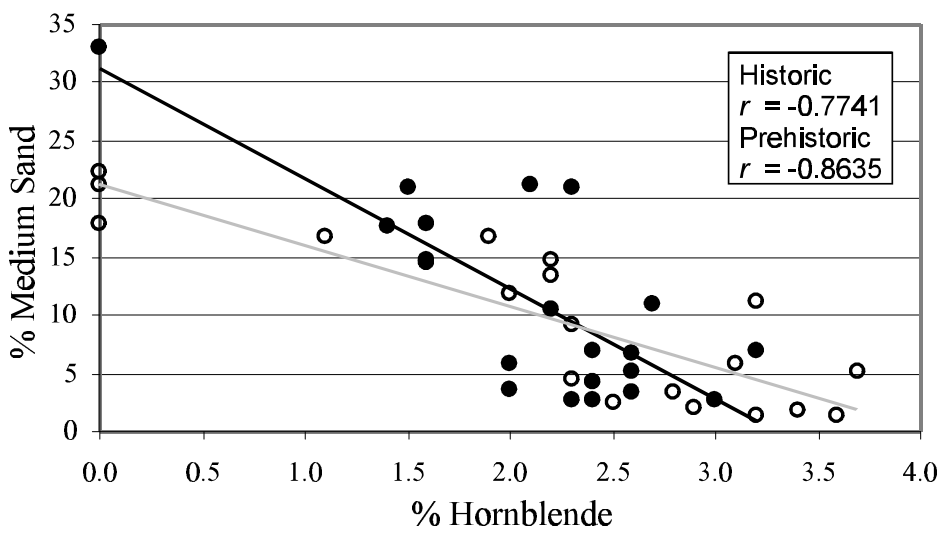

Historic $\bullet-$ Prehistoric $0-$ 


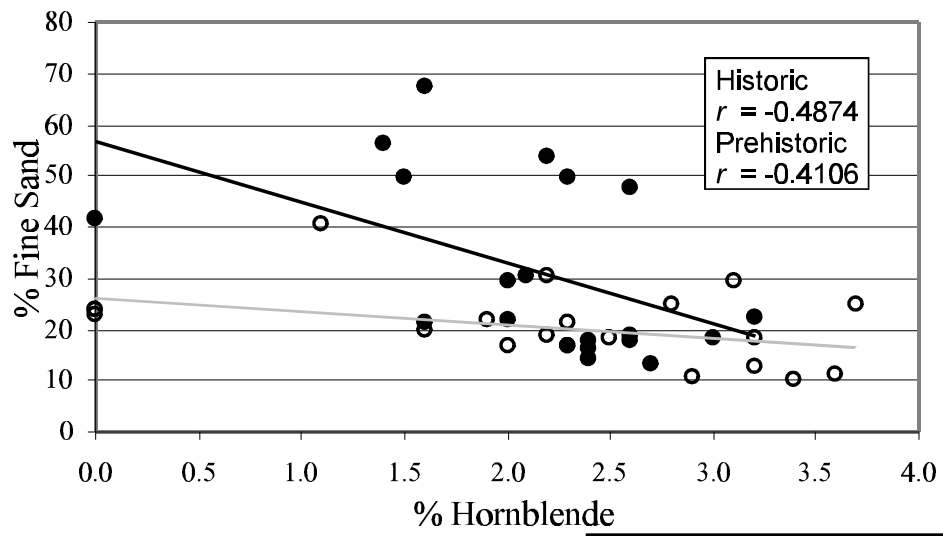

Historic $\bullet-$ Prehistoric $0-$

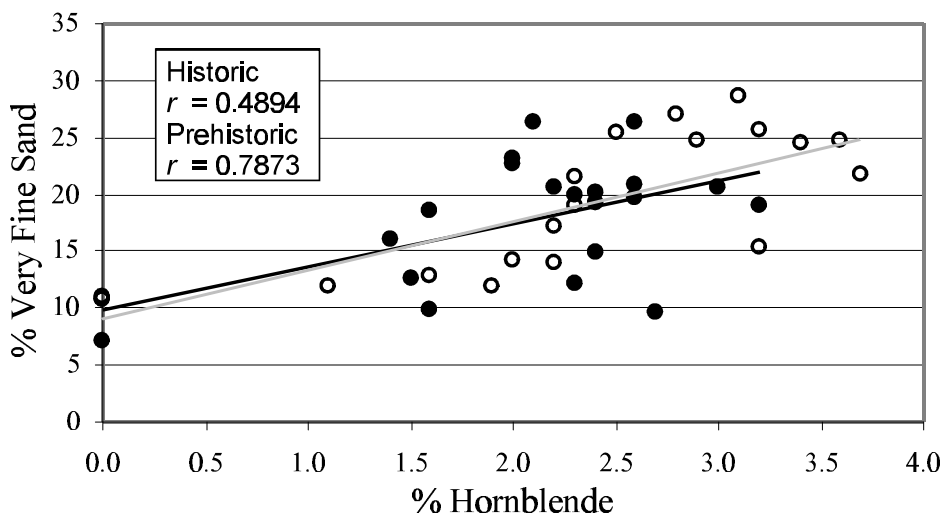

Historic $\bullet-$ Prehistoric $0-$

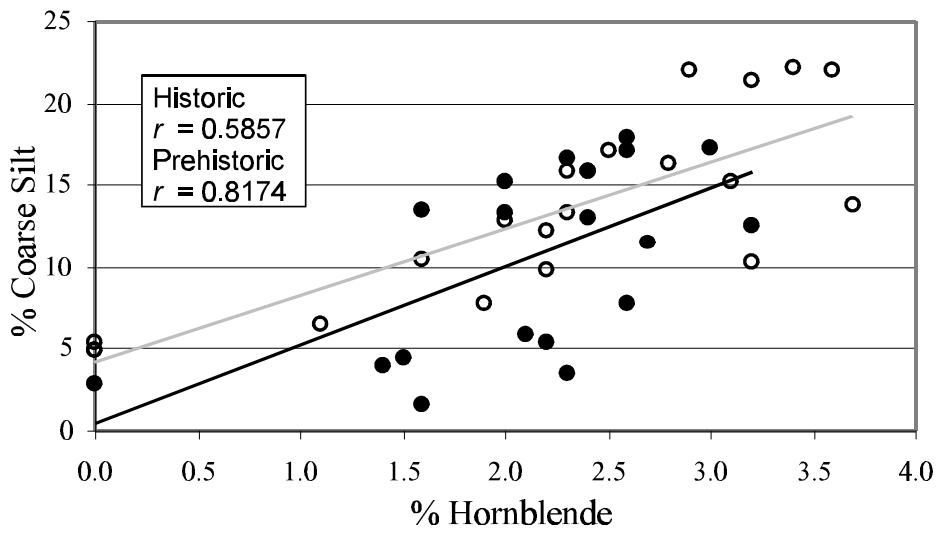

Historic $\bullet-$ Prehistoric $0-$ 


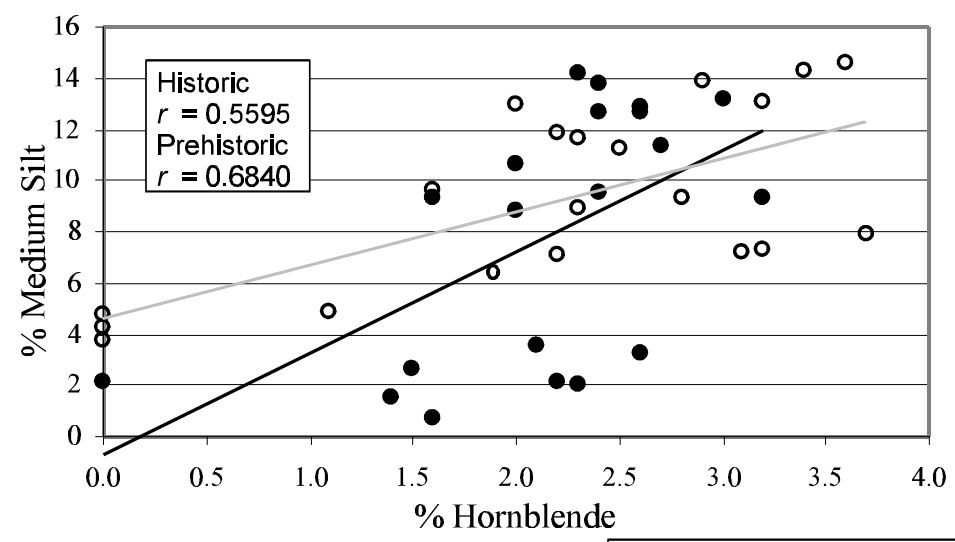

Historic $\bullet-$ Prehistoric $0-$

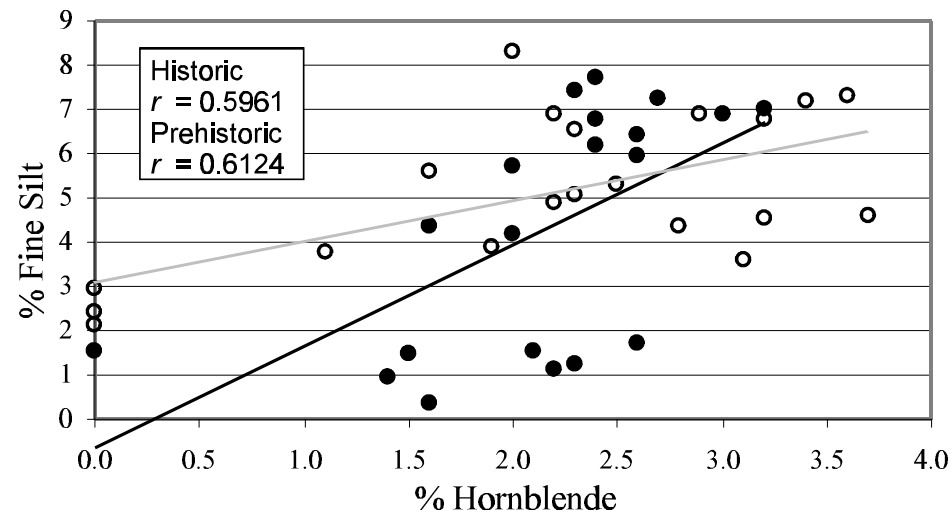

Historic $\bullet-$ Prehistoric $0-$

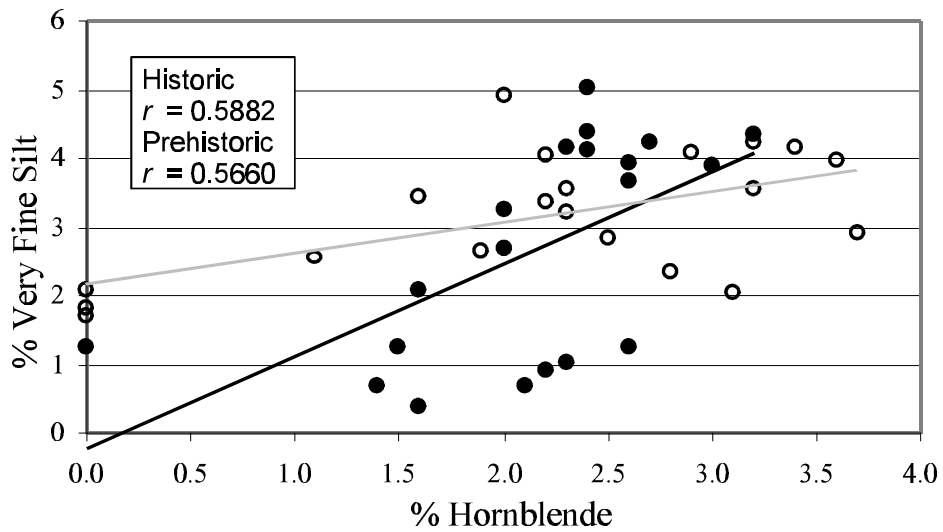

Historic $\bullet-$ Prehistoric $0-$ 


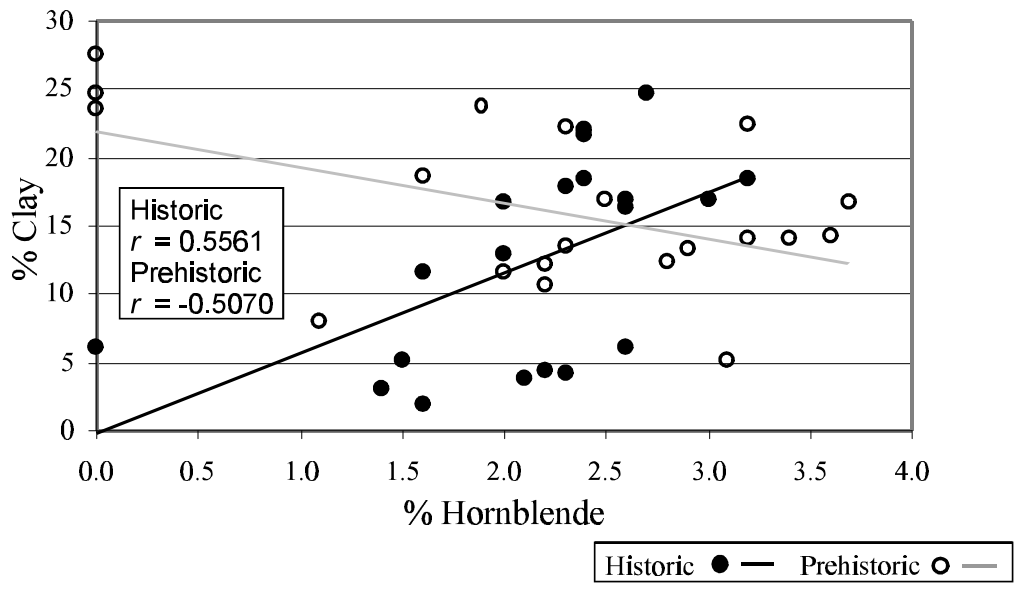



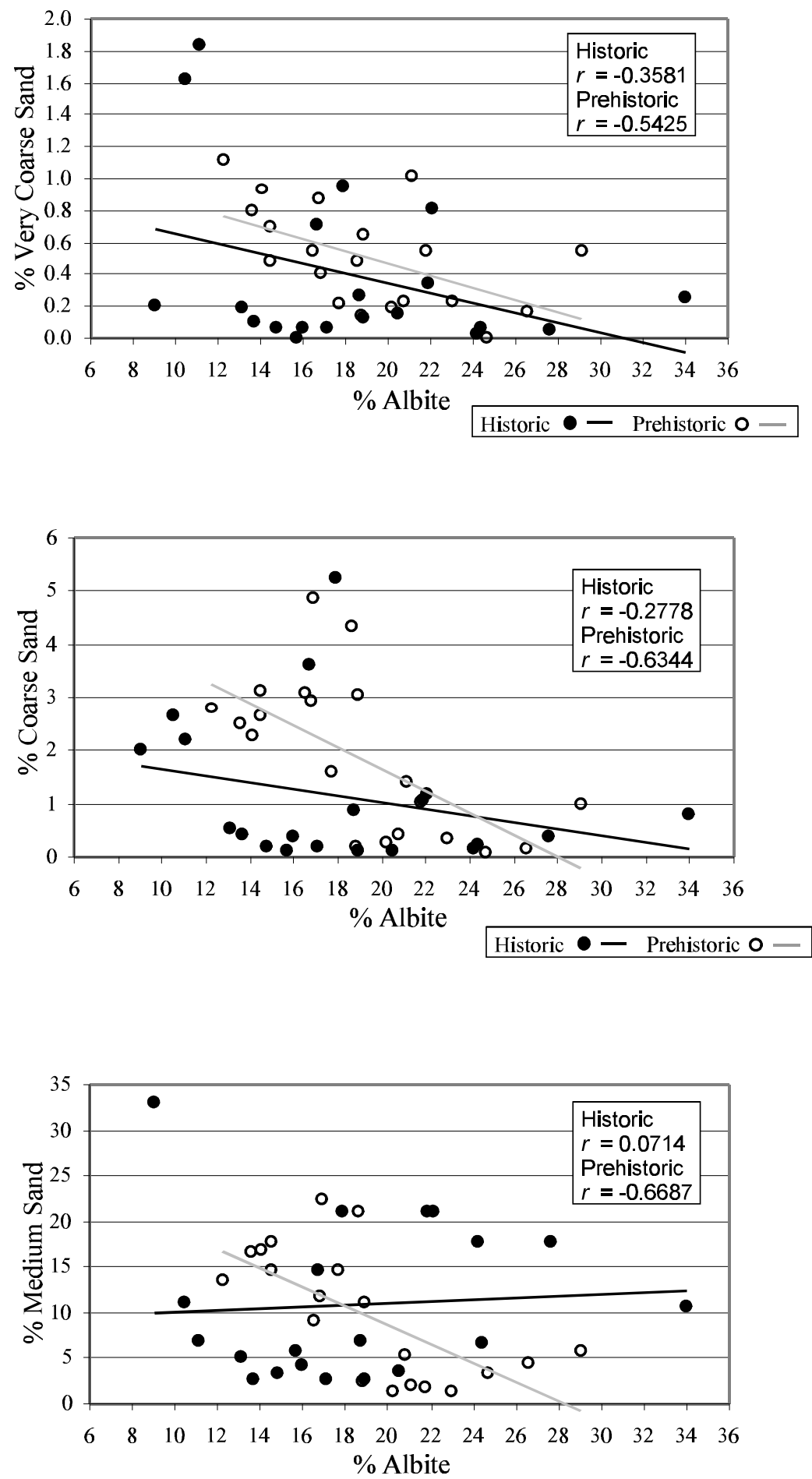

Historic $\bullet-$ Prehistoric $0-$ 


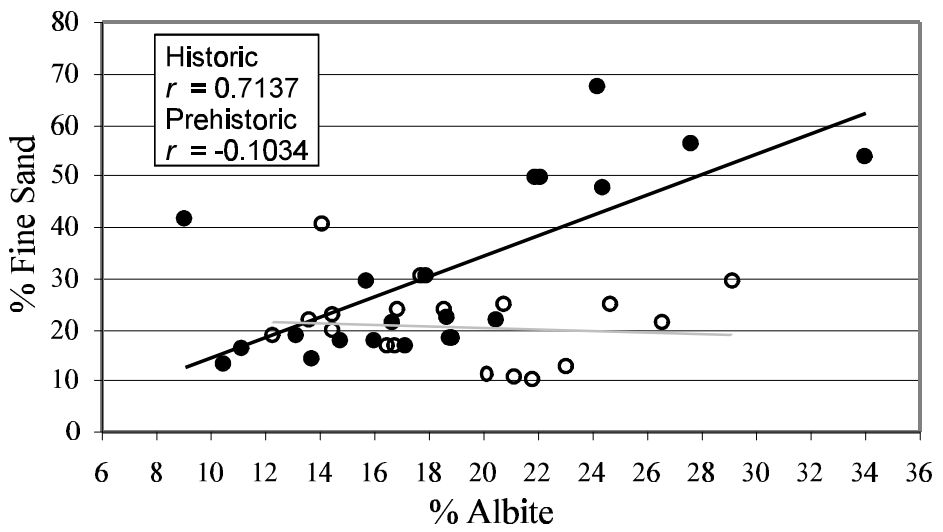

Historic $\bullet-$ Prehistoric $0-$

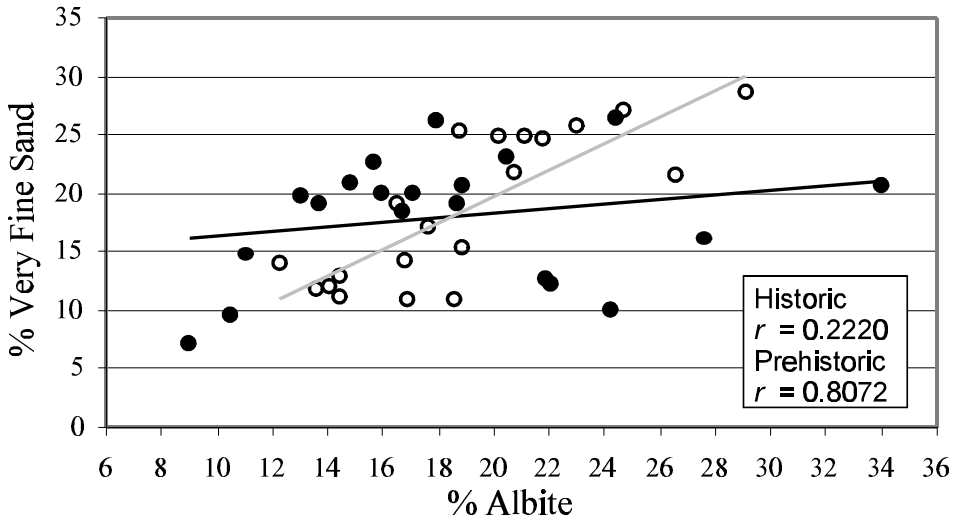

Historic $\bullet-$ Prehistoric $0-$

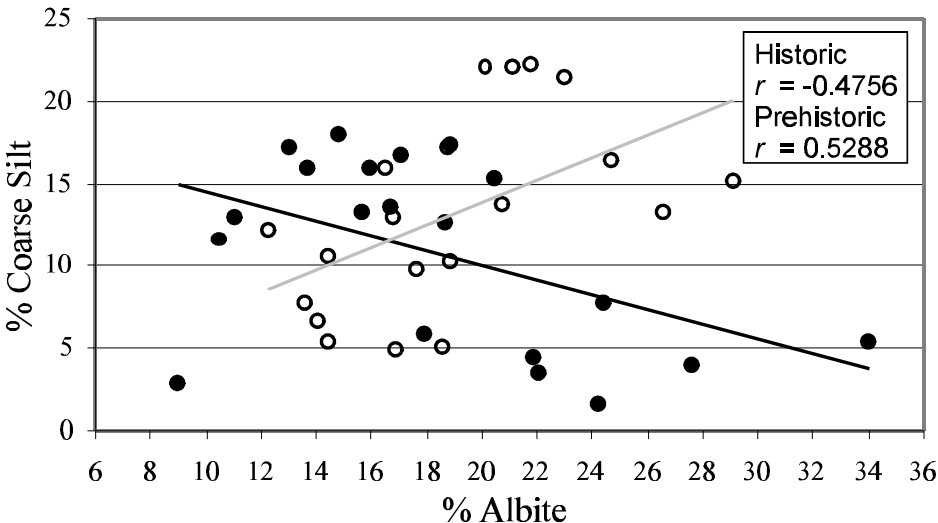

Historic $\bullet-$ Prehistoric $0-$ 


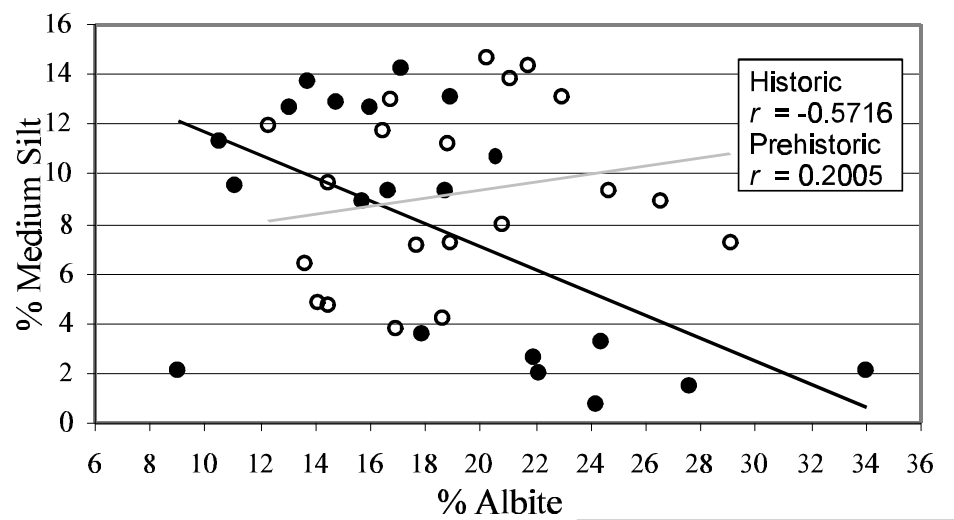

Historic $\bullet-$ Prehistoric $0-$

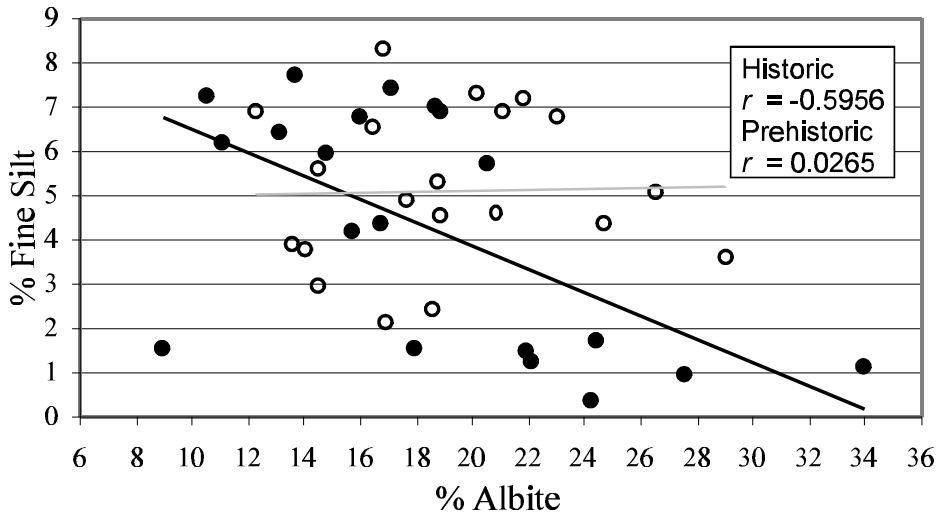

Historic $\bullet-$ Prehistoric $0-$

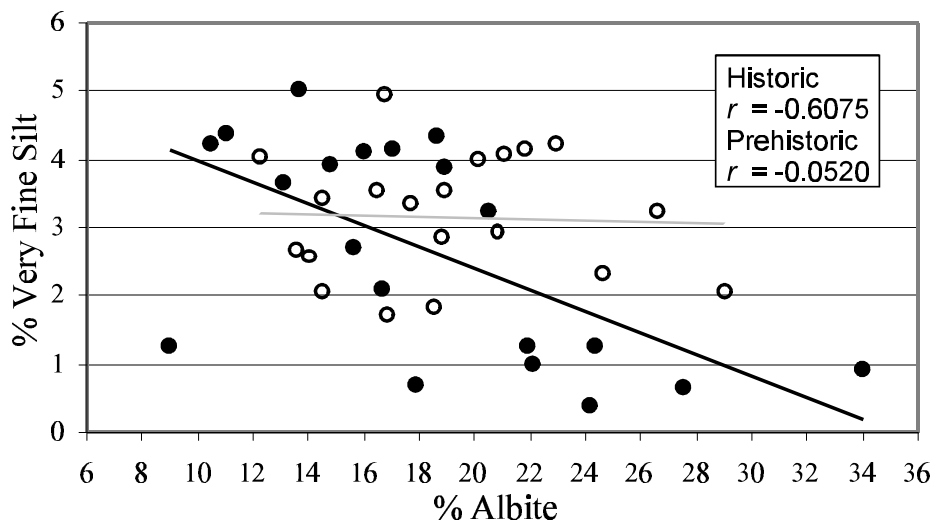

Historic $\bullet-$ Prehistoric $0-$ 


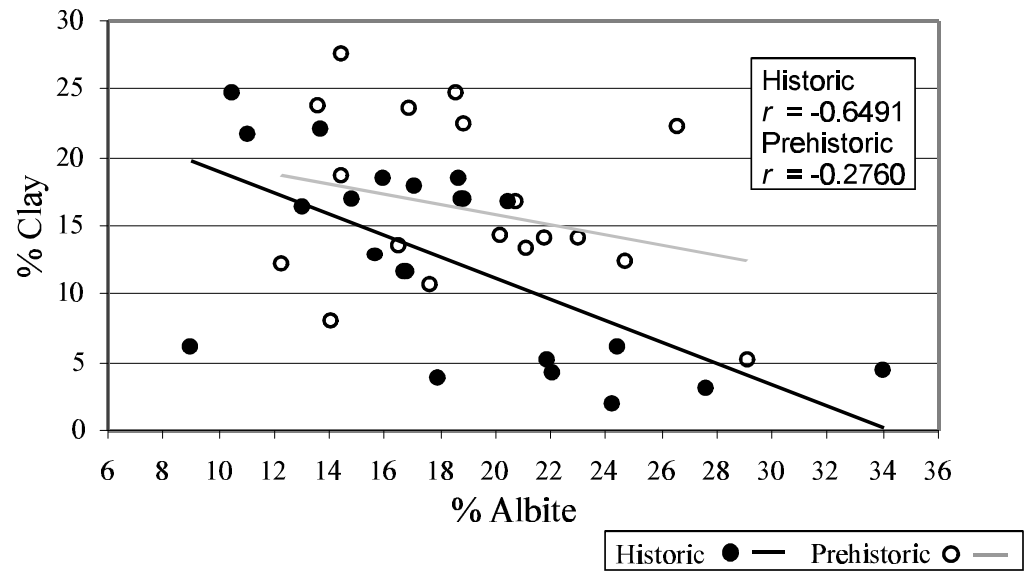




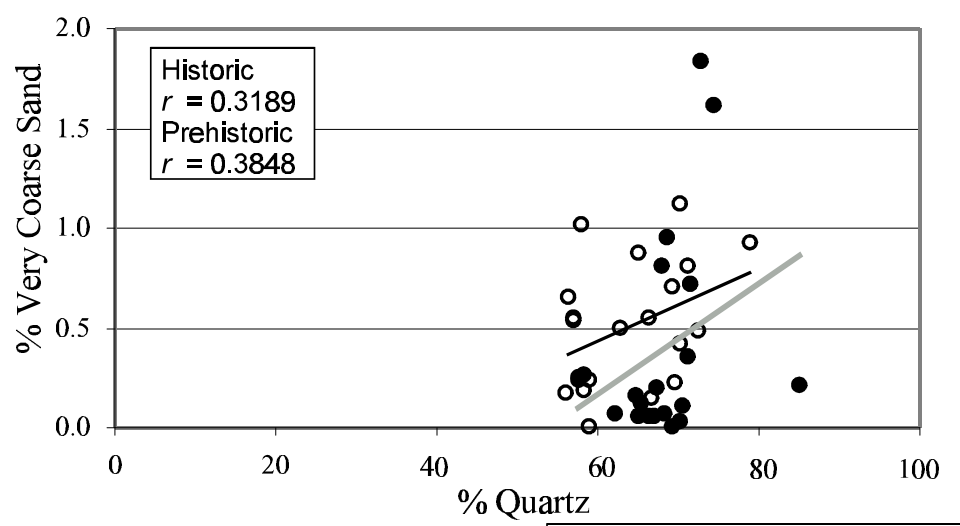

Historic $\bullet-$ Prehistoric $0-$
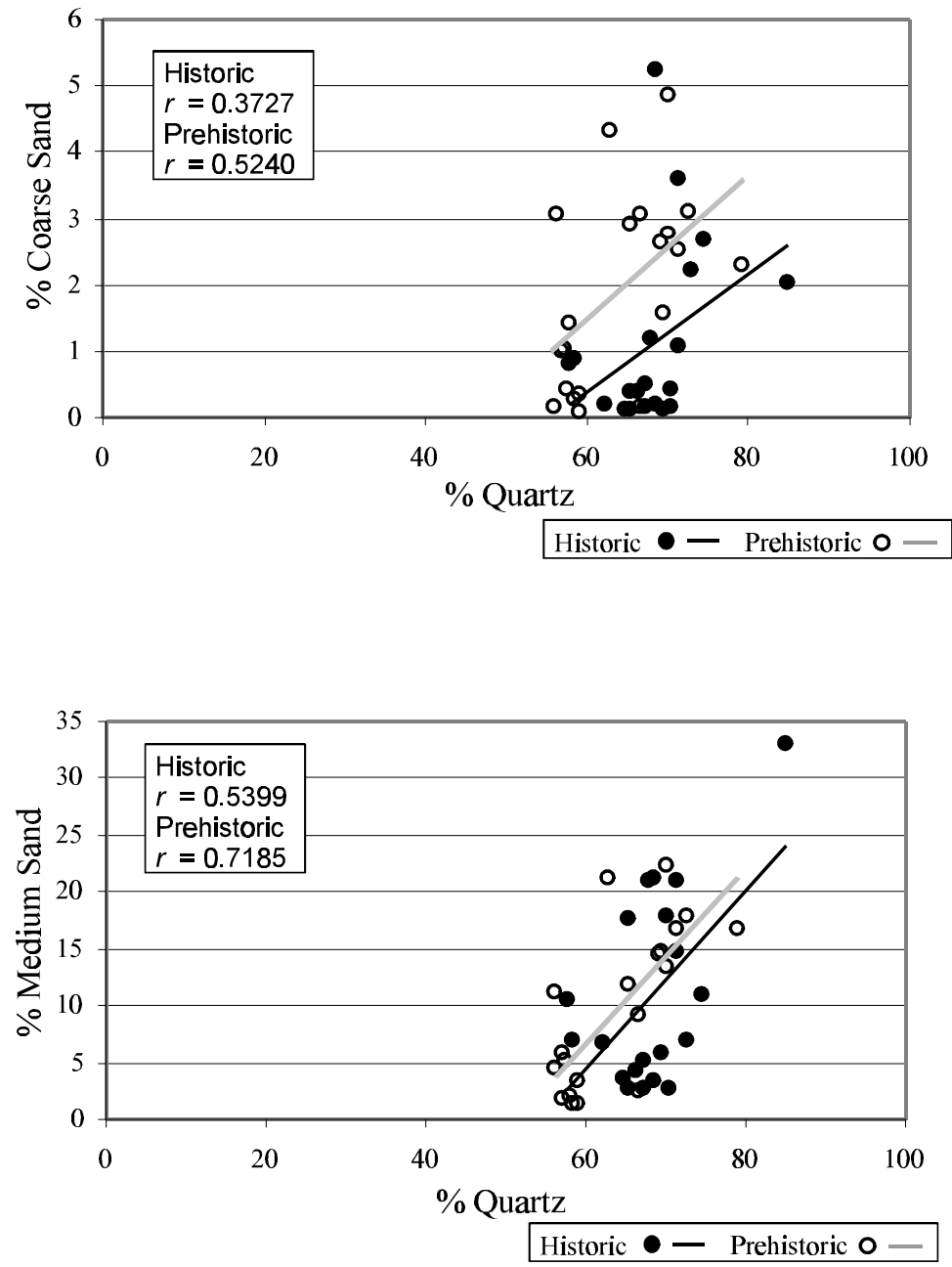


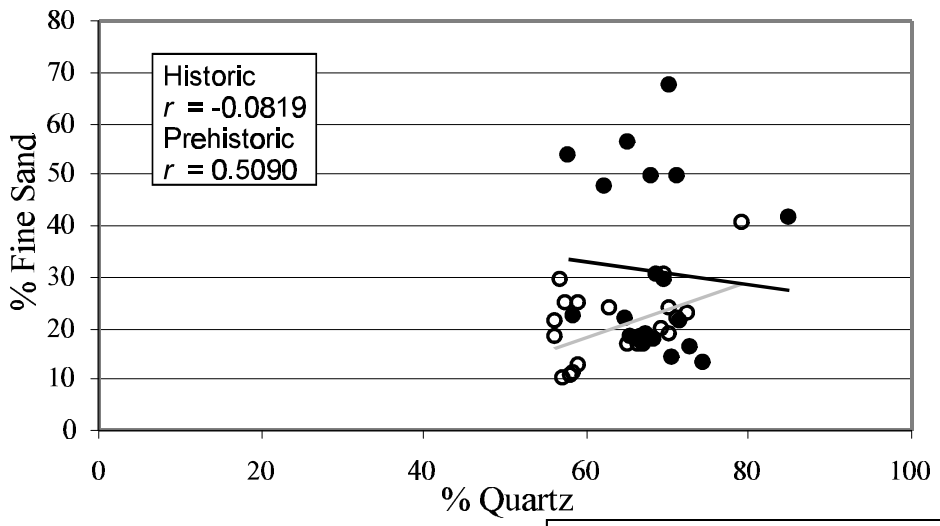

Historic $\bullet-$ Prehistoric $0-$

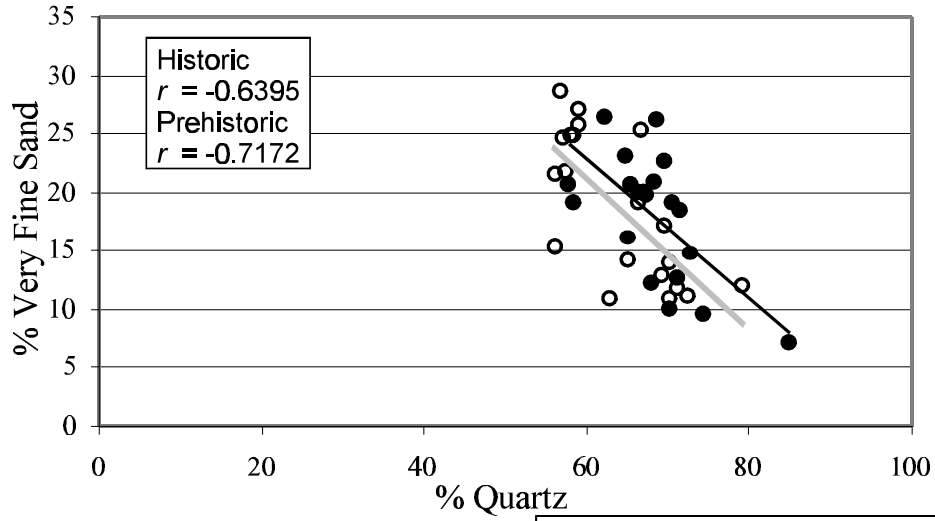

Historic $\bullet-$ Prehistoric $0-$

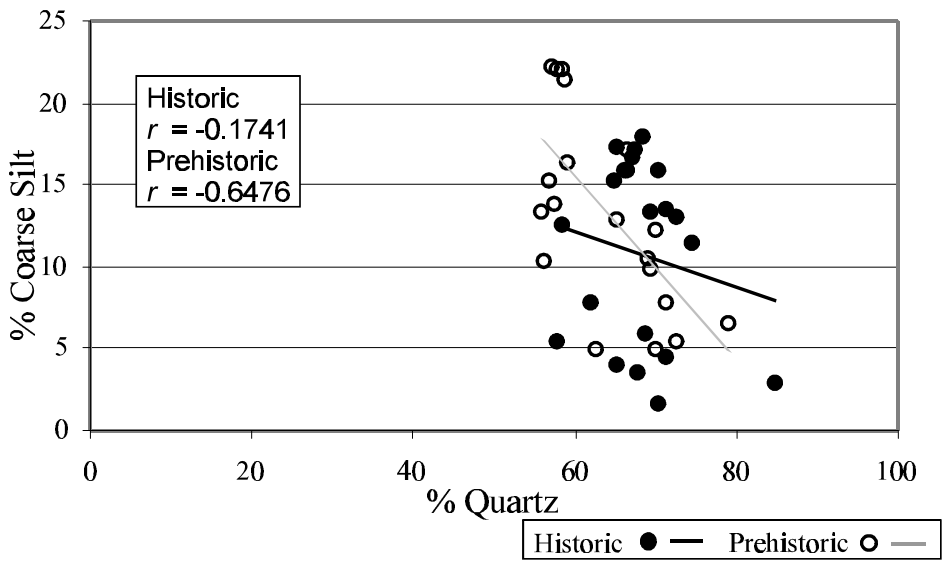




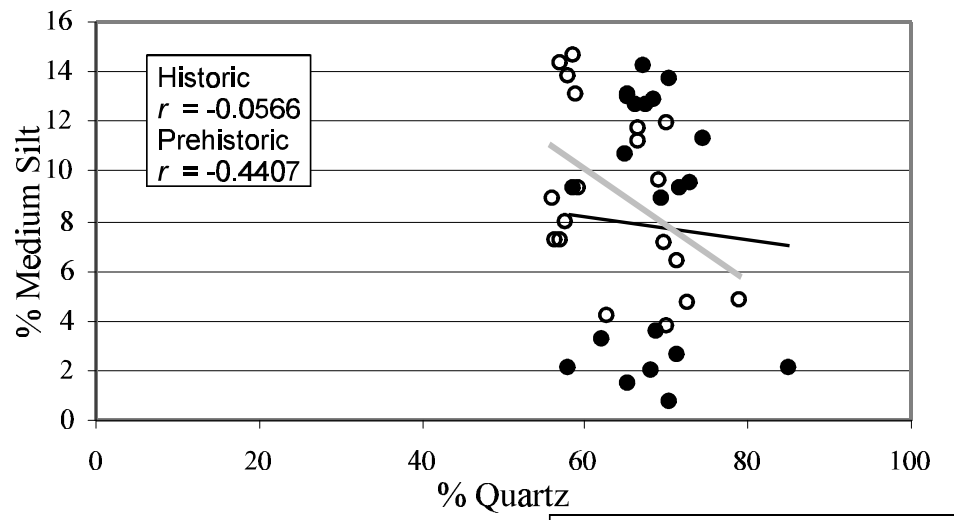

Historic $\bullet-$ Prehistoric $0-$
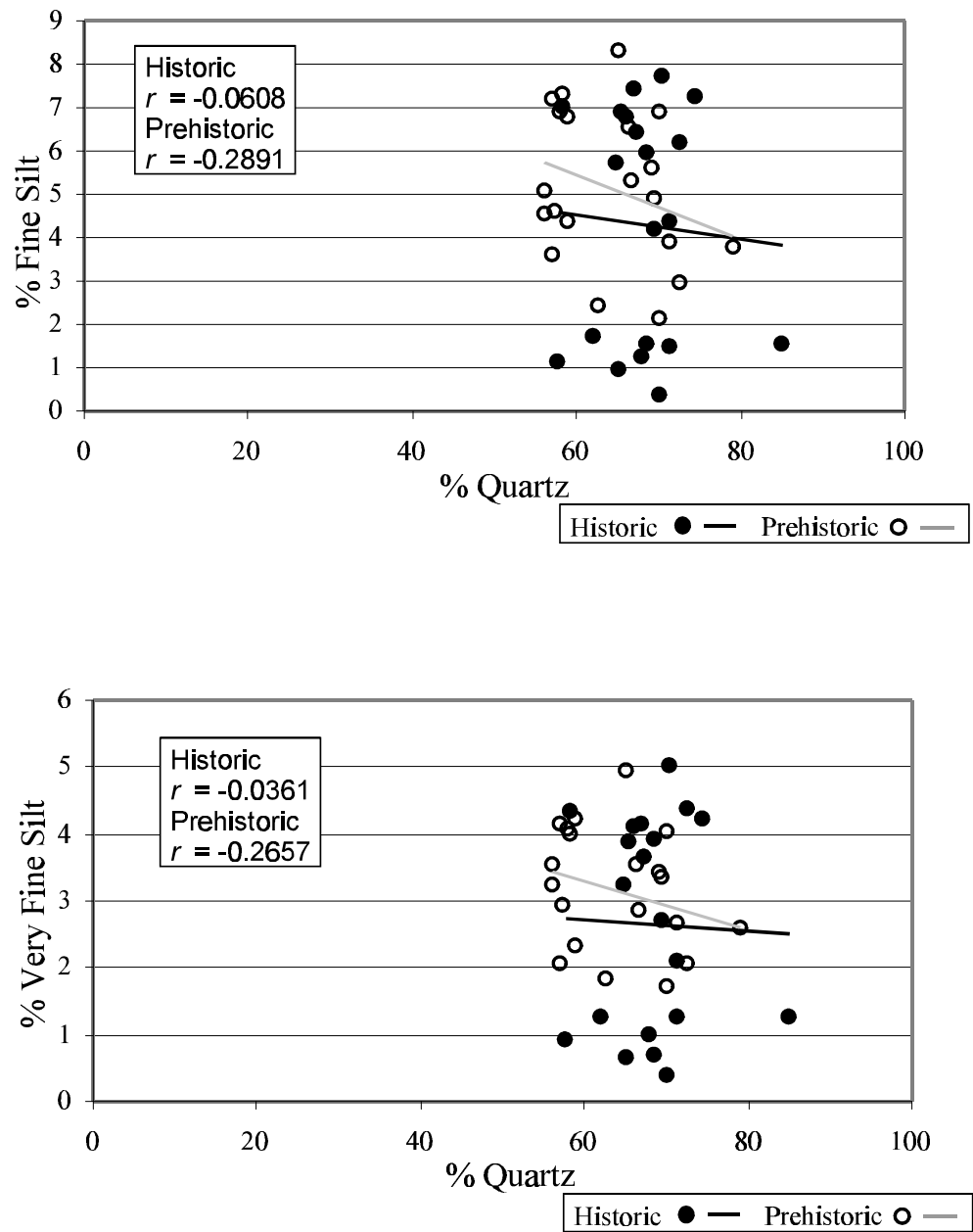


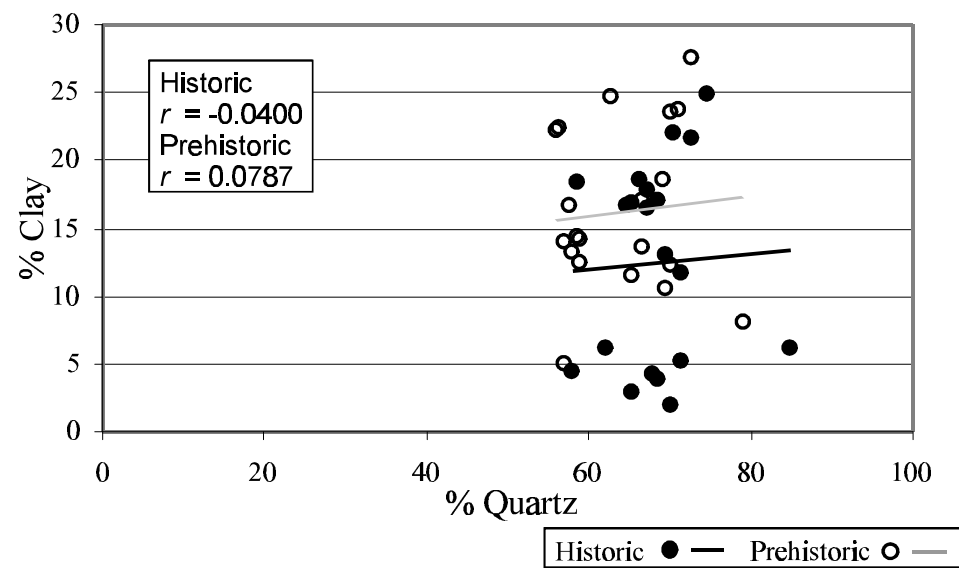

